Németh András Olivér

A GAZDASÁGI NÖVEKEDÉS ELMÉLETE ÉS A KELET-KÖZÉP-EURÓPAI TAPASZTALATOK 
Gazdaságpolitika Tanszék

\author{
Témavezető: \\ Bod Péter Ákos, az MTA doktora \\ egyetemi tanár
}

(C) Németh András Olivér 
Budapesti Corvinus Egyetem

\author{
Általános és Kvantitatív Közgazdaságtan \\ Doktori Iskola
}

\title{
A GAZDASÁGI NÖVEKEDÉS ELMÉLETE ÉS A KELET-KÖZÉP-EURÓPAI TAPASZTALATOK
}

doktori értekezés

Németh András Olivér

Budapest, 2016 



\section{TARTALOMJEGYZÉK}

Tartalomjegyzék

5. oldal

Ábrák jegyzéke

7. oldal

Táblázatok jegyzéke

9. oldal

Köszönetnyilvánítás

10. oldal

1. Bevezető gondolatok

11. oldal

2. A gazdasági növekedés elmélete

15. oldal

2.1. Bevezetés

15. oldal

2.2. Smith és Malthus - van-e növekedés?

16. oldal

2.3. Az első formális növekedési modellek - középpontban a fizikai tőke

24. oldal

2.4. A Solow-modell - endogén tökefelhalmozás, exogén technológia

30. oldal

2.5. További neoklasszikus növekedési modellek

37. oldal

2.6. A technológiai fejlődés endogén magyarázata

42. oldal

2.7. A humán tőke szerepe a gazdasági növekedésben

48. oldal

2.8. A növekedés fundamentális okai

52. oldal

2.9. Tanulságok Kelet-Közép-Európa számára

58. oldal

\section{A gazdasági növekedés empíriája}

61. oldal

3.1. Bevezetés

61. oldal

3.2. Növekedési számvitel

61. oldal

3.3. Fejlettségi számvitel

67. oldal

3.4. Növekedési regresszió

69. oldal

3.5. A térségre vonatkozó növekedési és fejlettségi számviteli eredmények

72. oldal

4. A kelet-közép-európai országok gazdasági növekedésének tapasztalatai

75. oldal

4.1. Bevezetés

75. oldal

4.2. A transzformációs visszaesés időszaka

79. oldal

4.3. Közeledés Nyugat-Európához

83. oldal

4.4. Demográfiai és munkaerő-piaci folyamatok

88. oldal

4.5. Tökefelhalmozás és nyitottság

92. oldal

4.6. Gazdasági visszaesés és ütemvesztés

102. oldal

4.7. A tartós növekedés feltételei

109. oldal 
5. Fiskális politika és gazdasági növekedés Kelet-Közép-Európában

111. oldal

5.1. Bevezetés

111. oldal

5.2. A fiskális politika és a gazdasági növekedés kapcsolata

111. oldal

5.3. Költségvetési politika és növekedés az Európai Unióban

115. oldal

5.4. Újraelosztás, költségvetési egyenleg és államadósság

Kelet-Közép-Európa országaiban

120. oldal

5.5. A kelet-közép-európai országok adórendszereinek jellemző vonásai

127. oldal

5.6. Politikai költségvetési ciklusok Kelet-Közép-Európában

136. oldal

6. Konklúzió

149. oldal

Függelék

155. oldal

Hivatkozások

163. oldal

Felhasznált adatbázisok

173. oldal

A jelöltnek a témában született publikációi

174. oldal 


\section{ÁBRÁK JEGYZÉKE}

1. ábra: A malthusi modell logikája

19. oldal

2. ábra: A Solow-modell egyensúlya

33. oldal

3. ábra: A reál GDP alakulása a kelet-közép-európai országokban $(1990=100 \%)$

77. oldal

4. ábra: Egy före jutó GDP az EU-15 átlagának százalékában (2010. évi árakon és vásárlóerő-paritáson számolva)

86. oldal

5. ábra: A teljes népesség és a 15-64 éves korosztály létszámának változása

(1990-2015)

89. oldal

6. ábra: A fő munkaerö-piaci mutatók alakulása a kelet-közép-európai országokban

7. ábra: Átlagos nettó beruházási ráta a kelet-közép-európai országokban

91. oldal

8. ábra: A bejövő FDI állománya a GDP százalékában

93. oldal

95. oldal

9. ábra: A folyó fizetési mérleg egyenlege a GDP százalékában

97. oldal

10. ábra: A külkereskedelmi nyitottság ((export + import) / GDP) alakulása

98. oldal

11. ábra: Külső egyensúlytalanság és ütemvesztés az Európai Unió országaiban

107. oldal

12. ábra: Jövedelem-újraelosztási ráta és gazdasági növekedés az Európai Unió országaiban

116. oldal

13. ábra: Költségvetési egyenleg és gazdasági növekedés az Európai Unió országaiban I.

117. oldal

14. ábra: Költségvetési egyenleg és gazdasági növekedés az Európai Unió országaiban II.

118. oldal

15. ábra: Államadósság és gazdasági növekedés az Európai Unió országaiban

119. oldal

16. ábra: A költségvetési kiadások GDP-arányának alakulása a kelet-közép-európai országokban

121. oldal

17. ábra: A költségvetési bevételek GDP-arányának alakulása a kelet-közép-európai országokban

122. oldal

18. ábra: A GDP-arányos költségvetési egyenleg alakulása a kelet-közép-európai országokban

125. oldal

19. ábra: A GDP-arányos államadósság alakulása a kelet-közép-európai országokban

126. oldal

20. ábra: Az adóbevételek közgazdasági funkciók szerinti bontása a GDP százalékában 128. oldal

21. ábra: Az adóbevételek közgazdasági funkciók szerinti bontása az adóbevételek százalékában

130. oldal

22. ábra: A legmagasabb személyi jövedelemadó-kulcsok az Európai Unió országaiban (2015)

132. oldal

23. ábra: A vállalati jövedelmeket terhelö legmagasabb adókulcsok az Európai Unió országaiban (2015)

134. oldal

24. ábra: Általános áfa-kulcsok az Európai Unió országaiban (2015)

135. oldal 
F1. ábra: Az egyes korcsoportok aránya a kelet-közép-európai országokban

155. oldal

F2. ábra: A foglalkoztatotti létszám alakulása $(1997=100 \%)$

156. oldal

F3. ábra: A foglalkoztatottsági ráta alakulása a kelet-közép-európai országokban

157. oldal

F4. ábra: A nettó beruházási ráta alakulása a kelet-közép-európai országokban

158. oldal

F5. ábra: Az éves FDI-beáramlás és a bruttó beruházások arányának alakulása

159. oldal

F6. ábra: A legmagasabb személyi jövedelemadó-kulcsok alakulása a

kelet-közép-európai országokban

160. oldal

F7. ábra: A vállalati jövedelmeket terhelő legmagasabb adókulcs alakulása a

kelet-közép-európai országokban

161. oldal

F8. ábra: Az általános áfa-kulcsok alakulása a kelet-közép-európai országokban

162. oldal 


\section{TÁBLÁZATOK JEGYZÉKE}

1. táblázat: Az Egyesült Államokhoz viszonyított 1988-as jövedelmi lemaradás, illetve a tőkeintenzitás, iskolázottság, valamint a munkatermelékenység hozzájárulása

2. táblázat: A transzformációs válságot követő gazdasági fellendülés jellemzői a kelet-közép-európai országokban

83. oldal

3. táblázat: A kelet-közép-európai országok egy före jutó GDP-je az EU-15 átlagának százalékában (folyó vásárlóerö-paritáson)

85. oldal

4. táblázat: Az Európai Uniótól származó nettó transzferek éves átlagos GDP-aránya

101. oldal

5. táblázat: A pénzügyi válság hatása a kelet-közép-európai országokban

102. oldal

6. táblázat: A GDP-növekedési ütem mérséklődése a pénzügyi válság után

104. oldal

7. táblázat: Politikai költségvetési ciklusok az eurózóna 12 alapító tagállamában, 1995-2008

141. oldal

8. táblázat: Politikai költségvetési ciklusok a kelet-közép-európai országokban, 1995-2008

143. oldal

9. táblázat: Politikai ideológia szerinti költségvetési különbségek a kelet-közép-európai országokban, 1995-2008 


\section{KÖSZÖNETNYILVÁNÍTÁS}

Ezúton szeretném kifejezni köszönetemet mindazoknak, akik segítettek az értekezés elkészítése folyamán. Először is köszönettel tartozom témavezetőmnek, Bod Péter Ákosnak, illetve értekezéstervezetem bírálóinak, Benczes Istvánnak és Oblath Gábornak hasznos javaslataikért, tanácsaikért. Igyekeztem legjobb tudásom szerint hasznosítani ezeket. Hálás vagyok mindazoknak, akik hozzászóltak a mühelyvitán, vagy más alkalommal véleményezték a készülő dolgozatot, és ezzel segítették munkámat: Andor Lászlónak, Berde Évának, Mihályi Péternek, Misz Józsefnek és Németh Petrának. Végül, de nem utolsósorban köszönöm szüleim, családom, barátaim és kollégáim támogatását, ami nélkül nem készülhetett volna el a dolgozat. 


\section{BEVEZETŐ GONDOLATOK}

A növekedéselmélet a közgazdaságtan egyik leghangsúlyosabb, egyben legizgalmasabb témaköre. Kiemelt fontosságát az adja, hogy a fejlődés iránti vágy az emberiség egyik (ha nem a) fö hajtóereje. Noha a gazdasági növekedés ennek a fejlődésnek csak egy szelete, közvetlen hatásain túl hozzájárulhat a társadalmi fejlődés más vonatkozásaihoz is. „A gazdasági növekedés nem csak azért lényeges, mert növekvő jóléthez vezet. A gyarapodó gazdaságú országokban lakó emberek általában boldogabbak és optimistábbak. Az anyagi fejlődés általános elégedettséghez vezet, a stagnálás és visszaesés nyomorhoz és pesszimizmushoz. A gazdasági növekedés azért is fontos, mert hiánya tartós munkanélküliséget és csökkenő életszínvonalat eredményez sokak számára.” (Marer, 2013, p. 242)

Nem meglepő hát, hogy a növekedés magyarázó tényezőinek, mechanizmusainak elméleti és empirikus kutatása régóta a közgazdaságtan homlokterében van. Ráadásul nagyon inspiráló, izgalmas kérdéskörről beszélünk, nem véletlenül írta Robert Lucas (1988, p. 5), hogy aki elkezd a gazdasági növekedés kérdésein gondolkodni, annak nehéz utána már másra gondolnia.

E dolgozat is a gazdasági növekedés témakörével foglalkozik. Két - más megközelítésű, de egymástól nem független - részből tevődik össze: a 2-3. fejezet a növekedéselmélethez kapcsolódó általános kérdéseket tárgyal, míg a 4-5. fejezet a kelet-közép-európai országok elmúlt negyedszázados növekedési teljesítményét vizsgálja az előbbiek tükrében.

A 2. fejezet a növekedéselmélet fejlödéstörténetét vázolja fel. Ez több mint pusztán a későbbiek megalapozásához szükséges irodalom-áttekintés, önmagában is célom volt egységes keretben bemutatni a legföbb növekedéselméleti modelleket, felmutatni a közöttük megfigyelhető kapcsolódási pontokat. E fejezet egyfelől túlmegy a növekedéselmélet standard tankönyvi tárgyalásán abban az értelemben, hogy az elméletek és modellek szélesebb körét tekinti át, másfelöl viszont abban is különbözik a tankönyvi megközelítéstől, hogy kevésbé az egyes modellek részletes elemzésére törekszik, ehelyett a hangsúly az egyes irányzatok egymásra hatásán, a növekedéselmélet fejlődési ívének kirajzolásán van.

Ebből a megközelítésből két következmény is adódik az értekezés szerkezetére vonatkozóan. Egyrészt a 2. fejezet - hogy lehetőleg önmagában is kompakt legyen 
- nem tartalmaz minden, a kelet-közép-európai országok elemzéséhez kapcsolódó elméleti összefüggést. Az 5. fejezetben külön kerülnek bemutatásra a költségvetési politikához kapcsolódó elméleti eredmények. Másrészt a 2. fejezet bővebb is, mint amit a dolgozat későbbi része feltétlenül igényelne. Természetesen több helyen is visszautalok az elmélettörténeti fejezetben tárgyaltakra, de itt szerepelnek olyan modellek is, amelyek később nem térnek vissza, azonban a fejlődéstörténet felvázolásához szükségesnek gondoltam őket.

A 3. fejezet tulajdonképpen kiegészíti az elözőt: a gazdasági növekedés elméleti összefüggései után ezek empirikus elemzésének módszertanát mutatja be. Három fő irányzatot tárgyalok: a növekedési számvitel, a fejlettségi számvitel és a növekedési regressziók eszköztárát. Maguknak a módszertanoknak a leírása mellett néhány fontos empirikus eredményt is idézek.

Mind a 2., mind a 3. fejezetre igaz, hogy nem kifejezetten a térség gazdasági teljesítményének elemzésével foglalkozik, hanem általánosabb megközelítést alkalmaz. Ezzel együtt, a dolgozat második feléhez való szorosabb kapcsolódás érdekében mind a kettőt a kelet-közép-európai tapasztalatokra vonatkozó alfejezet zárja. Egyrészt a 2.9. alfejezetben azt igyekszem kifejteni, hogy a növekedéselméleti irányzatok, modellek mely eredményei és következtetései tünnek a legfontosabbnak régiónk országai szempontjából, másrészt a 3.5. alfejezet a térségbeli gazdaságokra vonatkozó empirikus eredményeket tartalmazza. Mindez átvezet a dolgozat második felébe, amely kifejezetten régiónkra koncentrál.

A 4. fejezet a kelet-közép-európai országok 1990-2015 közötti időszakban nyújtott növekedési teljesítményét elemzi. A vizsgált országok köre az Európai Unió tizenegy volt szocialista tagállama: Bulgária, Csehország, Észtország, Horvátország, Lengyelország, Lettország, Litvánia, Magyarország, Románia, Szlovákia és Szlovénia. Minden esetben, amikor a „térségbeli államokról”, a „régió országairól”, „,KeletKözép-Európáról”, „a volt szocialista országokról” beszélek, ezekre az országokra gondolok, vagyis a dolgozatomban nem foglalkozom azokkal a rendszerváltó gazdaságokkal, amelyek (még) nem tagjai az Európai Uniónak. Ennek egyfelől az az oka, hogy noha már ez a tizenegy ország is sok szempontból heterogén képet mutat, az uniós tagság egy lényeges intézményi „közös nevezőt” jelent, ami a gazdasági növekedés keretei szempontjából is fontos. Másfelől ha kitágítanám a vizsgálat látókörét, sok esetben ütköznék adatszerzési problémába, amit az EU-tagállamokra való koncentrálással jelentős részben el lehet kerülni. 
Noha az egyes országok növekedési pályái között érdemi különbségek vannak, kirajzolódnak közös jellegzetességek. Mindegyik vizsgált gazdaságra igaz, hogy az elmúlt negyedszázados periódus három fő szakaszra osztható: 1. transzformációs visszaesés, 2. felzárkózási periódus, 3 . visszaesés és növekedési ütemvesztés. ${ }^{1}$ Ezekről a szakaszokról az alábbi fő megállapításokat tehetjük:

A rendszerváltozást minden térségbeli országban komoly gazdasági visszaesés kísérte: a GDP jelentősen csökkent az 1990-es szinthez képest és fél-másfél évtizedre volt szükség a rendszerváltozás elötti jövedelmi szint eléréséhez. Ez azonban nem csak mértékét, hanem jellegét tekintve is lényegesen különbözik egy ciklikus gazdasági visszaeséstől: a megszűnő és születő intézmények, koordinációs mechanizmusok közötti vákuum, a radikálisan megváltozott relatív árak miatti hatalmas gazdasági átrendeződés, a külkereskedelem és gazdasági kapcsolatok teljes átalakulása a vártnál és más recesszióknál lényegesen súlyosabb következményekkel járt.

A visszaesést követően az 1990-es évek közepén, második felében minden vizsgált országban egy gyors növekedési periódus indult. A nyugat-európai országoknál gyorsabb ütemü növekedés reálkonvergenciát is eredményezett a fejlettebb gazdaságokhoz viszonyítva. Ez a felzárkózási periódus alapvetően tőkefelhalmozáson alapult, amelyet jelentős részben külső források finanszíroztak. Hatalmas menynyiségű külföldi müködő tőke áramlott a gazdaságokba, ami lehetővé tette a gyors növekedést, azonban ez fenntarthatatlannak bizonyult a folyó fizetési mérleg kiugró mértékü hiányai miatt. Külön meg kell említeni az Európai Uniótól származó transzferek szerepét, amelyek szintén jelentős növekedési tényezőt jelentettek az uniós csatlakozást közvetlenül megelőző, illetve követő időszakban.

A térség országainak többségét a 2008-as pénzügyi válság során a fejlettebb gazdaságoknál súlyosabb visszaesés sújtotta. Azonban nem csak a GDP érdemi csökkenése következett a válságból, hanem a növekedési ütem tartósnak tünő mérséklődése is. Ennek fő okai a fő felvevőpiacok lassulása, a tőkebeáramlás visszaesése, illetve a folyó fizetési mérleg ezekből is következő kényszerű kiigazítása. A dolgozat a 2. fejezetben ismertetett elméleti keretekre építve három különböző narratívát vázol fel az ütemvesztés lehetséges magyarázataként. Ezek mindegyike arra a következtetésre vezet, hogy a korábbi gyors növekedés nem lehetett fenntartható a megváltozott külső (és belső) körülmények közepette.

${ }^{1}$ Lengyelország - egyedüliként az Európai Unió tagállamai közül - nem szenvedett el GDPcsökkenést 2009-ben, azonban a növekedési ütem lassulása a lengyel adatokon is megfigyelhetö. 
A dolgozat 5. fejezetét a költségvetési politika és gazdasági növekedés kapcsolatának szenteltem. Először ismertetem a fiskális politika és növekedés közötti viszonyra vonatkozó elméleti eredményeket, majd megvizsgálom a költségvetési adatok és növekedési ütemek közötti kapcsolatot az Európai Unió országai esetében. A pénzügyi válságot megelőző időszakra kirajzolódik az elméleti megfontolások és korábbi empirikus eredmények alapján várt egyértelmű negatív összefüggés az újraelosztási ráta és a növekedési ütem között, míg a jobb egyenlegpozíció az EU-15 országok és a volt szocialista tagállamok esetében is gyorsabb átlagos növekedéssel járt együtt. Szintén megfelel a várakozásoknak a 2002-es adósságállomány és a 2002-2015 közötti növekedési ütem közötti negatív összefüggés.

A fejezet további része a kelet-közép-európai országok fiskális politikáját jellemző makroadatok (költségvetés mérete, egyenlege, illetve az államadósság nagysága) változásait járja körül, majd a következő két - a költségvetési politika és gazdasági növekedés kapcsolatának témakörébe tartozó - hipotézist vizsgálja:

(1) a volt szocialista országok adópolitikája a gazdasági növekedés elösegítése érdekében szignifikánsan eltér a nyugat-európai gyakorlattól;

(2) a kelet-közép-európai országok - mint új demokráciák - esetében a fejlettebb gazdaságokhoz képest erőteljesebben jelennek meg az opportunista politikai költségvetési ciklusok, míg a gazdaságpolitikai ideológiáknak kisebb a jelentősége a fiskális politika vitele tekintetében.

Az első hipotézist a megfigyelések teljes mértékben alátámasztják: a keletközép-európai országokat alacsonyabb adócentralizáció jellemzi, kisebb a munkát és tőkét terhelő adók súlya a foglalkoztatottság bővítése és a tőkevonzó képesség javítása érdekében. Ehhez szorosan kapcsolódik a nyugat-európaiaknál alacsonyabb adókulcsok alkalmazása és a lineáris jövedelemadóztatás térségben bevett gyakorlata is. A második hipotézis csak részben nyer megerősítést: 1995-2008 között a ciklikusan kiigazított elsődleges egyenlegben hasonló mértékű választási ciklikusság figyelhető meg a kelet-közép-európai országokban, mint az eurózóna alapító tagállamaiban, azonban átlagosan rosszabb pozíció jellemezte térségünk országait, ami miatt ugyanolyan mértékü kilengés komolyabb fenntarthatósági kockázatot jelent. A gazdaságpolitikai ideológiákon alapuló tendenciózus fiskális politikai különbségek nem rajzolódnak ki a régióban.

Az értekezést konklúzió zárja, melyben néhány gondolat erejéig kitérek Magyarország növekedési kilátásaira is. 


\section{A GAZDASÁGI NÖVEKEDÉS ELMÉLETE ${ }^{2}$}

\subsection{Bevezetés}

Noha a makroökonómiai tankönyvek (például Mankiw, 1999, Romer, 2001, Sørensen és Whitta-Jacobsen, 2005) és a növekedéselméletet részletesebben tanulmányozó, magasabb szintü könyvek (például Acemoglu, 2009, Aghion és Howitt, 2009) is általában a Solow-modellel kezdik a témakör bemutatását, a növekedéselmélet gyökerei jóval korábbra nyúlnak vissza az időben.

Az ipari forradalom időszakát megelőzően hosszabb-rövidebb fellendülési és visszaesési időszakok váltakoztak, de nem mutatkozott hosszú távú növekedés az egy főre jutó jövedelemben, legalábbis nem olyan ütemü, ami egy-egy emberöltő alatt érzékelhető fejlődést jelentett volna. Angus Maddison számos becslést végzett a történeti GDP-idősorokra vonatkozóan, e becslések szerint világszinten az egy főre jutó GDP reálértéken nem nőtt időszámításunk kezdete és 1000 között, míg a növekedési ütem 1000 és 1820 között is csak évi 0,05 százalék volt. (Maddison, 2001, p. 265) Az ő munkáját továbbvivő Maddison Project (2013) adatai szerint például Angliában a világátlagnál gyorsabb növekedés figyelhető meg, de mai szemmel nézve ez is igen mérsékeltnek tekinthető: 1-1000 között 0,02 százalék, 1000-1500 között 0,07 százalék, 1500-1820 között 0,20 százalék évente.

Ezt Clark (2007) könyve bevezetőjében több különböző adattal egészíti ki: az 1800 körüli Angliában a várható élettartam nem volt hosszabb, mint a kőkorszaki gyüjtögető-vadászó társadalmakban, az emberek átlagos termete még csökkent is az évszázadok, évezredek folyamán, csakúgy, mint az étrendjük változatossága. Ellenben a kőkorszakban kevesebb munkával el lehetett érni egy hasonló jóléti szintet, illetve a társadalmi-vagyoni egyenlőtlenségek is nagyságrendileg kisebbek voltak, mint az ipari forradalom hajnalán. (i.m., pp. 1-2)

A folyamatos, érzékelhető gazdasági növekedés (és ezzel együtt az országok közötti igazán jelentős divergencia) útján az ipari forradalom indította el az emberiséget. Ennek fényében nem meglepő, hogy a gazdasági növekedés lehetőségének és korlátainak kérdései is a 18. század vége felé kezdték el igazán érdekelni a gondolkodókat. Érdekes ellentét húzódik e tekintetben a kor két - más-más kiindulópontú és

\footnotetext{
${ }^{2}$ E fejezet némileg rövidített változata jelenleg megjelenés alatt áll egy kétrészes cikk formájában:
} Németh $(2017 \mathrm{a}, 2017 \mathrm{~b})$. 
vizsgálati fókuszú, de egyaránt - nagy hatású szerzője, Adam Smith és Thomas Malthus között. Smith elméletének központi eleme, hogy a munkamegosztás és a piaci csere révén egyre nagyobb és nagyobb jólét érhető el. Ezzel szemben Malthus a föld jövedelemtermelő képességeinek korlátaiból kiindulva azt a következtetést vonja le, hogy „az emberek többsége számára a szegénység és nyomorúság elkerülhetetlen”. (Hild, 2002, p. 184)

Az azóta eltelt bő két évszázadban a közgazdászok a gazdasági növekedés lehetőségeinek és korlátainak különböző magyarázatait adták, számos olyan tényezőt azonosítottak, amelyek meghatározzák e lehetőségeket és korlátokat. E fejezetnek nem célja az összes növekedési elmélet és modell bemutatása, ehelyett arra törekszem, hogy a növekedéselmélet fejlödésének történeti ivét mutassam be, egyszerüsítésekkel, és a legfontosabb eredményekre koncentrálva. A modelleknek csak a fö jellemvonásait és legfontosabb egyenleteit mutatom be, részletes leírásuk és elemzésük megtalálható a hivatkozott tanulmányokban, illetve Romer (2001), Acemoglu (2009), valamint Aghion és Howitt (2009) könyveiben. Az alkalmazott jelölések nem mindenhol követik az eredeti cikkeket, ehelyett arra törekedtem, hogy az alábbiakban lehetőleg egységesek legyenek.

A fejezet alapvetően a történeti időrendet követi, de néhány helyen némileg felborítja azt, hogy jobban kirajzolódjon a növekedéselmélet fejlödéstörténetének logikai íve. Így tesz az első alfejezet is: előbb a malthusi problémakörrel foglalkozom, és utána térek rá Smith gazdasági növekedéssel kapcsolatos gondolataira, hiszen ez utóbbiak azok, amelyek a növekedéselmélet későbbi fejezeteihez szorosabban kapcsolódnak.

\subsection{Smith és Malthus - van-e növekedés?}

Ahogy fentebb már említettem, Smith és Malthus elmélete egymás ellenpontjainak tekinthető. Míg Smithnél a munkamegosztás és csere a fejlődés kimeríthetetlen lehetőségét hordozza magában, addig Malthus elméletében nincs tartós növekedés. Illetve ha növekszik is az összes termelés értéke, akkor az is az egyenlőtlenségek növekedésével jár együtt, vagyis az emberek széles tömegeinek életszínvonala nem javul az aggregált növekedés ellenére.

Malthus (1993 [1798]) nevezetes esszéjében tulajdonképpen két egyszerü feltevésre, pontosabban az ezek közötti ellentmondásra vezeti vissza állítását, miszerint nem elképzelhető az életszínvonal tartós, hosszú távú növekedése. E két feltevés: 
egyrészt az embernek élelemre van szüksége az életben maradáshoz, másrészt a nemek közötti vágy állandó és szükségszerü. (i.m., p. 12) E vágy ugyanis Malthus korában természetesen egyértelmüen a népesség folyamatos növekedése irányába mutató erőként hatott, míg a föld élelemtermő képessége ennek a népességnövekedésnek külső korlátot szab.

Malthus az ekkorra már függetlenedő és hatalmas szabad földterülettel rendelkező volt amerikai gyarmatokra vonatkozó megfigyelésekből indult ki: ha a társadalmi normák vagy éppen a rendelkezésre álló erőforrások ennek nem szabnak korlátot, akkor a népesség mintegy 25 évente megduplázódik, vagyis a demográfiai fejlödés állandó ütemü (mértani sort követ). Ezzel szemben az életben maradáshoz szükséges élelmiszerek és egyéb javak termelését még a termelésbe bevont földterület növelése, vagy a technológia fejlődése mellett is a legjobb esetben is csak adott mértékben (számtani sor szerint), vagyis csökkenő ütemben lehet bővíteni. ${ }^{3}$ Ez rövid időn belül is akkora egyensúlytalansághoz vezet, ami éhezők tömegeit vonja maga után. (i.m., pp. 15-17) Ez az egyensúlytalanság az, ami korlátozza a népesség növekedését: ahogy az egy före jutó termelés csökken, a halandósági ráta emelkedik, a születési ráta pedig mérséklődik.

A népességszám és az egy före jutó jövedelem alakulásában folyamatos ingadozás figyelhető meg. Ha a rendelkezésre álló javak és erőforrások ezt éppen lehetővé teszik, akkor a népesség növekedésnek indul. Ezzel rövid távon a termelés nem tud lépést tartani, aminek eredményeként az élelmiszerek és egyéb termékek ára felmegy, a népességnövekedésnek köszönhető munkaerö-bőség miatt pedig lecsökken a munkabér. Ez egyfelől jelentősen csökkenti az emberek reáljövedelmét, és így jólétét, másfelől pedig arra ösztönzi a földtulajdonosokat, hogy újabb munkaerő bevonásával növeljék a termelési szintet. A bővülő kibocsátás, valamint az alacsonyabb jövedelmek révén romló életszínvonal miatt csökkenő népszaporulat visszaállítja a kezdeti állapotot, majd a ciklus kezdődik elölröl. (i.m., p. 19)

\footnotetext{
${ }^{3}$ A 25 éves népességduplázódás - vagyis évi mintegy 2,8 százalékos népességnövekedés - hibás kiindulási pont. Az amerikai gyarmatok népessége valóban ilyen ütemben növekedett, azonban ez jelentős mértékben a folyamatos bevándorlás eredménye. Magának a számszerủ növekedési ütemnek, vagy a mértani és számtani sor szerinti növekedésnek azonban kicsi a jelentősége, a feltevés lényege, hogy a népesség gyorsabban növekszik, mint az eloállítható élelmiszer és egyéb javak mennyisége, más megfogalmazásban a termelésben a csökkenö hozadék elve érvényesül. Henry George, a 19. századi klasszikus politikai gazdaságtan amerikai képviselöje így jellemzi a mértani és számtani bővülés feltevésének jelentőségét és egyben valószerüségét: „Nem is érdemes azzal a szofizmával foglalkozni, melyet a növekedés mértani és számtani aránya foglal magában, mely az arányokkal való oly játék, hogy az alig emelkedik a nyúl és teknősbéka ismeretes találó kérdésének magaslatára, melyben a nyúl a teknősbékát örökké kergeti, anélkül, hogy valaha is utolérné.” (George, 1914 [1879], p. 100)
} 
Ráadásul Malthus azt is kiemeli, hogy az iparban alkalmazott tökeállomány, és így az ipari termelés bővülése ugyan hozzájárul a „nemzetek gazdagságához”, de valójában csökkenti a munkások jólétét. Ha ugyanis csak az iparban alkalmazott tökeállomány bővül, akkor megnövekszik a kereslet az ipari munkaerő iránt. Ez egyfelől az ipari munkások bérének emelkedését eredményezi, másfelől viszont hatására munkaerő áramlik az agrárszektor felől az iparba, és a mezőgazdasági munkaerő csökkenését legfeljebb csak ellensúlyozni tudja a fejlődő technológia, azaz a mezőgazdasági termelés nem bővül. Így az élelmiszerek, mezőgazdasági termékek ára emelkedik, vagyis az ipari munkásoknak csak a nominális, de nem a reálbére emelkedik. Az ipari munkások viszont rosszabb körülmények között kell, hogy dolgozzanak, vagyis a munkaerő átáramlása a mezőgazdaságból az iparba rontja a munkások egészségügyi állapotát, ami az életszínvonal egyik fontos tényezője. (i.m., pp. 125126)

A malthusi elmélet egyszerü modelljét Clark (2007) is bemutatja. ${ }^{4}$ A modell három alapfeltevése az, hogy

(1) a születési ráta az egy före jutó jövedelem növekvö függvénye;

(2) a halálozási ráta az egy före jutó jövedelem csökkenö függvénye és

(3) az egy före jutó jövedelem a népességszám csökkenö függvénye (a termelés nem tud lépést tartani a népesség növekedésével, csökkenő hozadék érvényesül).

A modell logikáját az 1. ábra mutatja. $B r$ jelöli a születési, $D r$ a halálozási rátát, az ábra alsó felén látható $T l$ görbe pedig az egy főre jutó jövedelem $(y)$ és a népességszám $(L)$ között fennálló, a technológiai színvonal által meghatározott kapcsolatot mutatja. Az egyensúlyi jövedelemszintet a születési és halálozási ráta határozza meg. Ez az a jövedelemszint $\left(y_{0}^{*}\right)$, amely mellett a népesség szintje nem változik $\left(L_{0}^{*}\right)$. Ha a kezdeti jövedelemszint ennél nagyobb, a születések száma meghaladja a halálozásokét, vagyis a népességszám növekedésnek indul, ami az egy före jutó jövedelem csökkenését eredményezi. Ha a kezdeti jövedelemszint $y_{0}^{*}$-nál kisebb, akkor ezzel ellentétes folyamat játszódik le.

\footnotetext{
4 Ahogy fentebb említettem, a makroökonómiai tankönyvek általában a Solow-modellel kezdik a gazdasági növekedés kérdéskörének bemutatását. Ez alól üdítő kivétel Williamson (2009) könyve, amelyben szintén szerepel a malthusi modell - az itt bemutatottól némileg eltérő módon, de hasonló logika alapján formalizálva.
} 


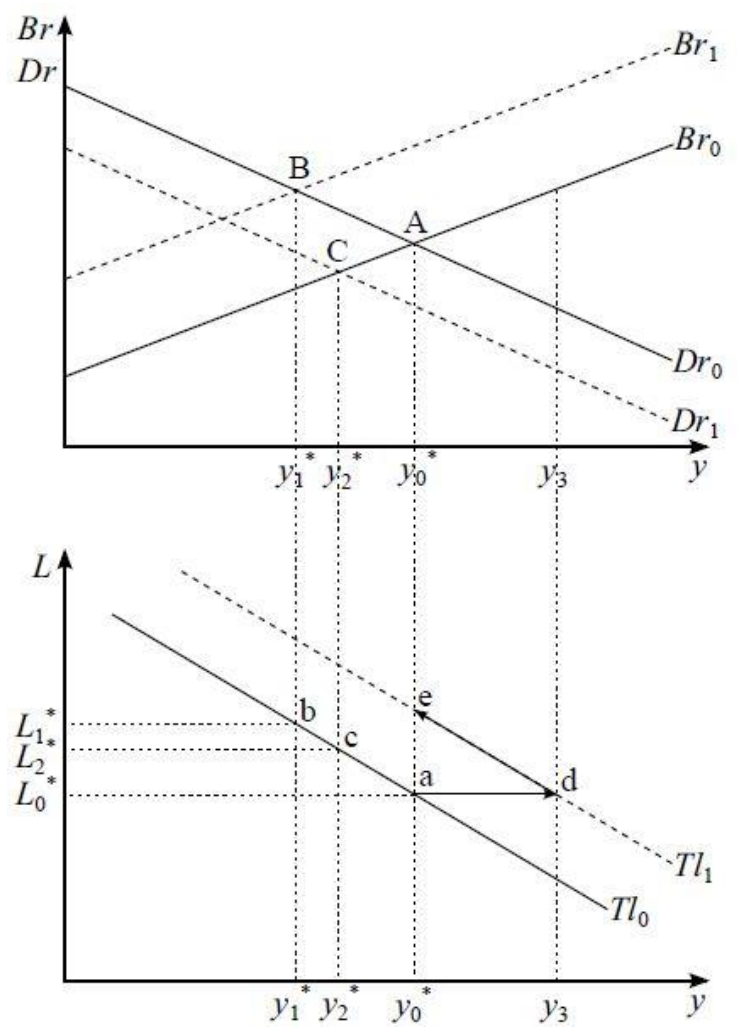

Saját szerkesztés Clark (2007) 2.1. és 2.3-2.5. ábrái alapján

Az 1. ábrán megvizsgálhatjuk, hogy a malthusi modellben milyen eredménynyel jár, ha a fö összefüggések megváltoznak. Ha például egy hosszabb békés időszakban a születési ráta megemelkedik (a $B r_{0}$ görbe eltolódik $B r_{1}$-be), akkor a népesség növekedésnek indul, aminek hatására az egy före jutó jövedelem lecsökken $y_{1}^{*}$-ra. Az ábra felső felén A pontból B-be, az alsó felén a-ból b-be jut a gazdaság. Hasonló eredményre vezet, ha például a közegészségügy javulása miatt csökken a halálozási arány. Ez esetben az ábra felső felében $\mathrm{C}$ pont, alsó felében c pont jelöli az új egyensúlyt: a kedvező demográfiai folyamatnak alacsonyabb egy före jutó jövedelem lesz az eredménye.

Ha pedig egy technológiai fejlesztés hatására a $T l_{0}$ görbe felfelé tolódik $T l_{1}$ be, akkor ennek hatására a jövedelem csak ideiglenesen emelkedik meg $y_{3}-\mathrm{ra}$. Ez nem lesz egyensúlyi állapot, ugyanis emellett a jövedelemszint mellett a születési ráta meghaladja a halálozási rátát és a népességszám emelkedésnek indul. $\mathrm{A} T l_{1}$ görbe mentén d pontból eljutunk e pontba, vagyis az egy főre jutó jövedelem visszatér a 
kiinduló egyensúlyi jövedelemszintre $\left(y_{0}^{*}\right)$, csak ez a fejlettebb technológia eredményeként már egy magasabb népességszámmal párosul.

Ez alapján a hagyományos erények és értékek (például béke, jótékonyság vagy szülői gondosság) károssá, „bűnné” válnak, hiszen az egy főre jutó jövedelem csökkenéséhez vezetnek a születési ráta emelkedésén vagy a halálozási ráta csökkenésén keresztül. ${ }^{5}$ Azok a tulajdonságok és jelenségek pedig, amelyeket általában rossznak gondolunk (például erőszak, rossz közegészségügy, önzés), magasabb átlagjövedelmet eredményeznek, így „erényként” viselkednek a malthusi rendszerben. (i.m., p. 37)

Malthus a túlnépesedést gátló tényezőket a preventív és a pozitív korlátok csoportjára osztotta. A kettő között az a különbség, hogy a preventív korlát megelőzi a túlnépesedést, míg a pozitív korlát az induló túlnépesedést állítja le valamilyen „,külső” beavatkozás formájában. Mivel utóbbi körbe olyan fájdalmas jelenségek tartoznak, mint az éhínségek, járványok és háborúk, ezért javasolja Malthus az önmegtartóztatás preventív korlátját, amivel a túlnépesedés és a pozitív korlátok aktivizálódása is elkerülhető. ${ }^{6}$

Az 1. ábrához kapcsolódó fejtegetésből azt a következtetést is levonhatjuk, hogy tartós jólétnövekedésre a malthusi modell értelmében akkor van lehetőség, ha a technológiai színvonal folyamatosan növekszik, ráadásul gyorsabb ütemben, mint hogy a népességszám ,alkalmazkodni” tudjon. Ennek értelmében azért nem lehetett tehát az ipari forradalmat megelőzően érdemi gazdasági növekedés, mert a technológiai fejlödés üteme nem volt elég gyors.

Smith (1999 [1776]) fő müve abból indul ki, hogy a munkamegosztás révén egyre nagyobb és nagyobb jólét érhető el a társadalom számára. A munkamegosztás

\footnotetext{
${ }^{5}$ Malthus erőteljesen bírálta az Angliában akkoriban hatályos szegénytörvényeket, amelyek támogatást, illetve munkát biztosítottak a szegényeknek. Érvelése szerint ezek a törvények a szegények számának növekedéséhez, ezen keresztül pedig helyzetük még kilátástalanabbá válásához vezetnek. Malthus a szegénytörvények eltörlését javasolta, és noha ez nem valósult meg, bírálata is hozzájárult ahhoz, hogy William Pitt miniszterelnök visszavonja a támogatási rendszer bövítésére vonatkozó tervezetét. (Gilbert, 1993, p. xvi.)

${ }^{6}$ A fentebb már idézett Henry George erősen bírálja a malthusi elméletet, és a belőle adódó következtetéseket. „Azzal a föltevéssel kezdődik, hogy a népesség mértani arányban törekszik növekedni, holott az élelmiszerek csak számtani arányban növelhetök, mely föltevés ép oly helyes és nem helyesebb, mint ama tény alapján, hogy egy kis kutya farka kétszer akkora lesz, míg súlya ennyi fontra nő, mértani haladványt konstatálni farkáról és számtani haladványt súlyáról. És az e föltevésből levont következtetés ép olyan, amilyent Swift szatírájában egy idáig kutyátlan sziget tudósaira foghatott volna, akik e két arányt egybevetve, azt a »meglepő következtetést« vonhatták volna le, hogy mikor a kutya ötven font súlyt érne el, farka egy mérföldes lenne, melyet fölötte nehezen csóválhatna és ennélfogva a bandázs preventív akadályát ajánlnák, mint egyetlen alternatívát a folytonos amputálás pozitív akadályával szemben.” (George, 1914 [1879], p. 110)
} 
ugyanis lehetővé teszi az emberek számára a szakosodást, ami nagyobb kibocsátást eredményez. Egyrészt mert így az emberek egyre nagyobb gyakorlatra, ügyességre tesznek szert, másrészt így csökken a különböző tevékenységek közötti váltás időigénye, harmadrészt a specializáció révén mindenki jobban ösztönözve van (és mindenkinek több lehetősége is van) a saját tevékenységét segítő gépek, új eljárások kitalálására, kifejlesztésére. (i.m., I. kötet, pp. 112-115) „Ez a munkamegosztás révén bekövetkező termelékenységnövekedés az, amely egy jól kormányzott társadalomban elvezet az általános bőséghez, ami a legalsóbb rétegekre is kiterjed.” (i.m., I. kötet, p. 115)

A munkamegosztás az emberek kooperációra való hajlamából ered, így annál nagyobb lehetőségek adódnak erre, minél nagyobb egy adott területen a népsürüség, illetve minél nagyobb az elérhetö piac mérete. A kis népsűrüségü, falusias helyeken minden embernek nagyrészt önellátónak kell lennie, hiszen nincs lehetőség megfelelő szakosodásra. Még ha van is valamilyen szintü specializáció, egy asztalos például egyszerre lesz ács és bútorasztalos, fafaragó és bognár. Ezzel szemben egy nagyvárosban akkora az egyes részterületekre vonatkozó kereslet, hogy ezeket a szerepeket mind-mind külön szakemberek fogják betölteni, sőt, ezen belül is további szakosodás lesz megfigyelhető. Smith ehhez egy földrajzi elemet is hozzátesz: a folyók és tengerek távolabbi piacokat is elérhetővé tesznek azáltal, hogy a vízi kereskedelem lényegesen hatékonyabb (adott költséggel jóval nagyobb mennyiségü árut tud megmozgatni), mint a szárazföldi. (i.m., I. kötet, pp. 121-124) Így az ipar és a gazdaság először a vízi kereskedelem számára elérhető területeken indul fejlődésnek, hiszen itt nagyobb léptékben is lehetséges a csere és szakosodás.

A népsürüség, piacméret és gazdasági fejlettség ráadásul egymásra is hatnak. Egy fejlődő területre megindul a bevándorlás az ország más részeiről, így megnő a népsürüség, a piac mérete. Mindez további szakosodást és azon keresztül további termelékenység- és jólétnövekedést tesz elérhetővé, ez pedig további bevándorlást fog ösztönözni. Ilyen értelemben azt is mondhatjuk, hogy a smithi teória tulajdonképpen egy korai endogén növekedési modellnek tekinthető.

A későbbi növekedési modellekből ismert eszköztárral egyszerüen formalizálhatjuk a smithi elméletet. Az aggregált termelési függvény

$$
Y=(A \cdot L)^{\alpha} \cdot T^{1-\alpha},
$$

ahol $Y$ jelöli a kibocsátást, $L$ a népességszámot (egyben a munkaerő-állományt), $T$ a termelésbe bevont föld (természeti korlátok által adott) mennyiségét, $A$ pedig a mun- 
ka hatékonyságát. Ez a fentebbiek értelmében a népességszám függvénye: minél nagyobb a népsürüség, annál több lehetőség áll rendelkezésre a munkamegosztásra, ami annál hatékonyabb munkavégzésre vezet, vagyis $A=g(L)$, ahol $g^{\prime}(L)>0$. Mindezek alapján a termelési függvény az

$$
Y=[g(L) \cdot L]^{\alpha} \cdot \bar{T}^{1-\alpha}
$$

formát ölti. Az egy főre jutó jövedelem

$$
y=[g(L) \cdot L]^{\alpha} \cdot \bar{T}^{1-\alpha} / L=[g(L)]^{\alpha} \cdot L^{\alpha-1} \cdot \bar{T}^{1-\alpha} .
$$

Belátható, hogy ha a $g(L)$ függvény rugalmassága nagyobb, mint $(1-\alpha) / \alpha$, akkor az egy főre jutó jövedelem a népességszám növekvő függvénye. A következtetést érdemben nem változtatja meg az sem, ha a munka hatékonyságát nem a népességszám, hanem a népsürüség függvényének tekintjük: $A=g\left(L_{T}\right)$. Ekkor a népsürüségen értelmezett $g$ függvény rugalmasságának kell $(1-\alpha) / \alpha$-nál nagyobbnak lennie ahhoz, hogy az egy före jutó jövedelem a népsürüség növekvő függvénye legyen. Abban az esetben pedig, ha az $A$ változót nem munkakiterjesztö, hanem semleges hatékonysági változóként szerepeltetjük (vagyis $Y=A \cdot L^{\alpha} \cdot T^{1-\alpha}$ ), akkor enyhébb feltételt kapunk a $g$ függvény rugalmasságára. Ez esetben a rugalmasságnak (1 $\alpha$ )-nál kell nagyobbnak lennie ahhoz, hogy az egy főre jutó jövedelem a népességszám, illetve népsürüség növekvő függvénye legyen.

Míg Malthusnál a magasabb népességszám a termőföld eltartóképességének korlátossága miatt alacsonyabb jövedelmi szinthez vezetett, addig Smithnél nagyobb mértékü munkamegosztást, így nagyobb hatékonyság és jólét elérését tette lehetővé. Bár a két elmélet ellentétes logikára épül, érdemes megemlíteni Kremer (1993) tanulmányát, melyben a szerző ötvözi a smithi és a malthusi megközelités elemeit. Modelljében a nagyobb népességszám nagyobb innovációs valószínűséget, így gyorsabb technikai haladást eredményez ${ }^{7}$, de van egy malthusi korlát is: a technológiai színvonal lehatárolja a fenntartható népességszámot.

Modellje legegyszerübb formájában két egyenletre épül. A termelési függvényt az

$$
Y=A \cdot L^{\alpha} \cdot T^{1-\alpha}
$$

\footnotetext{
${ }^{7}$ Kremer (1993) tehát kifejezetten technológiai fejlődésről beszél, nem pedig a munkamegosztás által lehetővé tett termelékenység-növekedésről, azonban az eredmények szempontjából másodlagos, hogy a nagyobb népesség milyen csatornákon keresztül segíti elő a termelékenység javulását. Ráadásul újra megemlíthetjük, hogy Adam Smith is azt tartotta a munkamegosztás egyik legföbb hasznának, hogy nagyobb lehetőséget és ösztönzést ad az innovatív termelési eljárások és eszközök feltalálására.
} 
egyenlet írja le, míg a technológiai fejlődés ütemét az

$$
\dot{A} /_{A}=g \cdot L
$$

összefüggés, ahol $g$ egyszerüen egy ember átlagos hozzájárulását jelöli a technológiai fejlődéshez. Az egyszerüség kedvéért a termőföld nagyságát 1-re normálja, így a termelési függvény az $Y=A \cdot L^{\alpha}$ formára egyszerüsödik, az egy före jutó jövedelem pedig $y=A \cdot L^{\alpha-1}$. A malthusi korlátot az jelenti, hogy van egy adott $\bar{y}$ jövedelemszint, ami alatt a népességszám csökken. Ez alapján a népességszám állandósult állapotbeli értéke kifejezhető a technológiai színvonal függvényében:

$$
\bar{L}=(\bar{y} / A)^{\frac{1}{\alpha-1}} \text {. }
$$

Mivel $\bar{y}$ állandó, ezért ennek segítségével megadható az állandósult állapotbeli népességszám változása a technológiai fejlődés függvényeként:

$$
\dot{L} /_{L}=(1 /(1-\alpha)) \cdot(\dot{A} / A)=(g /(1-\alpha)) \cdot L . \text { (i.m., pp. 685-686) }
$$

Ezzel támasztja alá azt az empirikus megfigyelést, hogy az utóbbi néhány évtizedet leszámítva az emberi történelem során egyértelmü pozitív kapcsolatot lehetett megfigyelni a világ népessége és a népességnövekedési ütem között. Modellje alapján a nagyobb népesség gyorsabb technikai haladást eredményez, ami gyorsabb népességnövekedést tesz lehetővé. ${ }^{8}$

Ezt a következtetést Kremer (1993) az egymástól tengerrel és így évszázadokig, évezredekig technológiailag is elválasztott földrészekre vonatkozó megfigyelésekkel is alátámasztja. A jégkorszak elmúltával, mintegy időszámításunk előtt 10.000 évvel megszünt a szárazföldi összeköttetés az Óvilág, Amerika, Ausztrália, Tasmania és a Flinters-szigetek között. Az öt térség populációja ekkoriban feltehetően hasonló technológiai színvonalon állt, és hasonló lehetett a népsürüség is. Az eltérő területméret miatt azonban ez természetesen eltérő népességszámot jelent. A felfedezések korában, 1500 körül, illetve azt követően állt helyre az összeköttetés az öt vizsgált terület között. Ekkorra hatalmas különbségek mutatkoztak már a technológiai fejlettségben, pontosan a kezdeti népesség szerinti sorrendben. ${ }^{9}$ Ha a technológiai fejlődés

\footnotetext{
${ }^{8}$ Kremer (1993) tanulmányában a modell összetettebb változatai is szerepelnek, egyrészt a népességszám és technológiai fejlődés, másrészt az egy főre jutó jövedelemszint és népszaporulat közötti kapcsolatra vonatkozó feltevéseket is általánosítja. Ha utóbbi összefüggésről azt feltételezzük, hogy egy bizonyos jövedelemszintig az életszínvonal és a népességnövekedés között pozitív, afelett negatív kapcsolat van, akkor a modellel az 1960-as évektől kezdődően világszinten mérséklődő népszaporulat is magyarázhatóvá válik.

${ }^{9}$ A régészeti leletek alapján Tasmania lakóinak technológiája még vissza is fejlődött, az idők folyamán elvesztették például a csonteszközök készítésének képességét. Az Ausztrália és Tasmania között
} 
üteme független a népességszámtól, akkor annak a valószínűsége, hogy ugyanez a sorrend véletlenül alakuljon ki, kevesebb, mint 1 százalék (1:120). (i.m., pp. 709710)

\subsection{Az első formális növekedési modellek - középpontban a fizikai tőke}

Noha - ahogy fentebb láthattuk - már a klasszikus iskola közgazdászai is foglalkoztak a gazdasági fejlődés kérdéskörével, írásaikban megmaradtak a verbális eszközök alkalmazásánál. A gazdasági növekedés első formális, dinamikus modelljei a 20. század első felében jelentek meg. Ezek közül jelentősége miatt kiemelkedik a Harrod-Domar-modell. ${ }^{10}$

Harrod (1939) tanulmánya elsősorban a dinamikus megközelítés újdonságértéke miatt érdekes. Valójában nem tekinthető kifejezetten a hosszú távú növekedés leírásának, hiszen együtt vizsgálja a gazdasági növekedés és a gazdasági ingadozások kérdését. Modellje három alapfeltevésre épül:

(1) a megtakarítások kínálata elsösorban a nemzeti jövedelemtöl függ;

(2) a megtakarítások iránti keresletet, vagyis a beruházási aktivitást a kibocsátás növekedése határozza meg;

(3) a megtakarítások kereslete és kínálata kiegyenlitődik. (i.m., p. 14)

Vagyis formálisan $s \cdot Y=b \cdot \Delta Y$, ahol $s$ a megtakarítási ráta, $b$ pedig az egységnyi kibocsátástöbblethez szükséges tökeállomány-bővülés (amit többek között a technológiai színvonal határoz meg). ${ }^{11}$ Ez alapján a gazdasági növekedés egyensúlyi üteme $\Delta Y / Y=s / b$. (i.m., p. 17)

A modell egyensúlyi növekedési pályája instabil: ha adott megtakarítási ráta mellett valamilyen váratlan sokk hatására a gazdasági teljesítmény ennél gyorsabb ütemben nő, akkor a konstans tőkeigény miatt a megvalósultnál nagyobb mennyiségü beruházásra lenne szükség ahhoz, hogy ez fenntartható legyen (a $\Delta Y / Y>s / b$ egyenlőtlenség egyenértékü a $b \cdot \Delta Y>s \cdot Y$ egyenlőtlenséggel). A megnövekvő beruházás

elterülő, de az őslakosok számára mindkét területtől elzárt Flinters-szigeteken pedig a hanyatlás következtében évezredekkel ezelött ki is halt a népesség. (Kremer, 1993, pp. 709-710)

${ }^{10}$ Bár például Mankiw (1999) vagy Williamson (2009) elterjedten használt makroökonómiai tankönyvei nem tartalmazzák, a modell leírása magyar nyelven megtalálható Meyer és Solt (1999, pp. 390-396) tankönyvében.

${ }^{11} \mathrm{Az}$, hogy ez a marginális tőkeigény konstans (kiegészítve azzal, hogy tőke nélkül nincs termelés), tulajdonképpen azt jelenti, hogy a kibocsátás a tőkeállomány lineáris függvénye:

A tőke határterméke tehát állandó.

$$
Y=1 / b \cdot K
$$


viszont tovább növeli az aggregált keresletet, vagyis még jobban felgyorsul a gazdasági növekedés. Ennek ellenkezője játszódik le, ha a gazdasági növekedés elmarad az egyensúlyi ütemétől. A lassabb növekedés felesleges kapacitás kialakulását eredményezi, vagyis a tőketulajdonosok úgy érzékelik, hogy túl sok beruházást hajtottak végre. Emiatt visszafogják a beruházási hajlandóságukat, ami az előzőekben leírtak értelmében elmélyülő válsághoz vezet. (i.m., p. 22)

Domar (1946) egy egyensúlyi (teljes foglalkoztatottság melletti) növekedési pálya feltételeit vizsgálta. Egyensúlyban egy nemzetgazdaság potenciális kibocsátása megegyezik a tényleges kibocsátással: $P=Y$. A potenciális kibocsátás viszont egyenesen arányos a tőkeállománnyal: $P=\kappa \cdot K$. Ahhoz, hogy ez az egyensúly fennmaradjon, a tényleges kibocsátásnak minden időszakban ugyanolyan mértékben kell nőnie, mint a potenciális kibocsátásnak: $\dot{P}=\dot{Y}$. A megelőző összefüggés értelmében

$$
\dot{P}=\kappa \cdot \dot{K}=\kappa \cdot I=\kappa \cdot s \cdot Y^{12},
$$

ahol már azt a feltevést is felhasználtuk, hogy a megtakarítási ráta konstans. Az egyensúlyi növekedési pályán tehát $\dot{Y}=\kappa \cdot s \cdot Y$, vagyis a növekedési ütem

$$
\dot{Y} / Y=\kappa \cdot s .(\text { i.m., p. 141) }
$$

Ez az eredmény jól láthatóan megegyezik Harrod (1939) eredményével, a paraméterek egyértelmü megfelelésével: $\kappa=1 / b$. A két szerző egymástól függetlenül jutott azonos végkövetkeztetésre, eredményük pedig Harrod-Domar-modellként vonult be a közgazdaságtani elmélettörténetbe.

A Harrod-Domar-modellben tehát az aggregált termelési függvény a nagyon egyszerü, $Y=\kappa \cdot K$ alakot ölti. Ez értelmezhető úgy, hogy a gazdasági növekedés kulcsa kizárólag a fizikai tőke, vagyis az elmaradottabb országok felzárkóztatásához elegendő a beruházási aktivitás növelése. Azonban a termelési függvény egyszerü formája nem jelenti azt, hogy a szerzők csak a fizikai tőkének tulajdonítottak volna jelentőséget a termelési folyamatban. A többi termelési tényező (például munkaerő, technológiai színvonal) tulajdonképpen a tőke termelékenységét leíró $\kappa$ együtthatóba sürítve jelenik meg. Az, hogy ez konstans, alapvetően egy matematikai egyszerüsítésnek tekinthető, noha - ahogy Domar (1952, p. 488) idézi a korabeli empirikus

\footnotetext{
${ }^{12}$ Domar (1946) azt az eshetőséget is megvizsgálja, hogy az új beruházások kisebb arányban növelik meg a potenciális kibocsátást, mint a potenciális kibocsátás és a már létező tőkeállomány aránya. Ennek az lehet az oka, hogy az új beruházásokkal létrejött kapacitások erőforrásokat (például munkaerőt) vonnak el más területekröl, így a nemzetgazdaság teljes termelése kevésbé növekszik az új beruházások hatására. Ebben az esetben az egyensúlyi növekedési rátát az új beruházások kapacitásnövelö képessége határozza meg a teljes potenciális kibocsátás és teljes tőkeállomány aránya helyett.
} 
eredményeket - a 19. század második fele és a 20. század közepe között az átlagos tőketermelékenység valóban nem változott érdemben.

Érdemes megemlíteni azt is, hogy Domar (1946) tanulmányában a beruházások I mennyisége valójában nettó, vagyis az amortizáció pótlásán felüli beruházást jelent. Ha ezzel szemben az I jelölést a későbbi hagyománynak megfelelően a bruttó beruházásokra használjuk, akkor a modell annyiban változik, hogy a potenciális kibocsátás növekménye

$$
\begin{gathered}
\dot{P}=\kappa \cdot \dot{K}=\kappa \cdot(I-\delta \cdot K)=\kappa \cdot(s \cdot Y-\delta \cdot K)= \\
=\kappa \cdot(s \cdot Y-\delta \cdot Y / \kappa)=\kappa \cdot s \cdot Y-\delta \cdot Y,
\end{gathered}
$$

ahol $\delta$ az amortizációs ráta, vagyis az egyensúlyi növekedési pályán

$$
\dot{Y} /_{Y}=\kappa \cdot s-\delta
$$

A Harrod-Domar-modell legjellegzetesebb, egyben leginkább kritizált jellemzője az egyensúlyi növekedési pálya instabilitása. ${ }^{13}$ Ez tulajdonképpen abból a feltevésből következik, hogy a tőkekoefficiens állandó, vagyis nincs semmilyen helyettesíthetőség a tőke és munkaerő (vagy más termelési tényezők) között. Ahogy Solow (1956, p. 66) megfogalmazza, ez azt jelenti, hogy a Harrod-Domar-modell a hosszú távú növekedés problémakörét rövid távra érvényes eszközökkel vizsgálja. Ez a felismerés vezette Solow-t arra, hogy megalkossa közismert modelljét, mely egyetlen lényeges elemben tér el a Harrod-Domar-modelltől, nevezetesen abban, hogy nincs rögzített tőkekoefficiens, hanem a neoklasszikus elemzés hagyományos feltevésével élve a tőke és munkaerö különböző kombinációival elö lehet állítani ugyanazt a kibocsátási szintet. Jelentősége miatt a teljes 2.4. alfejezet a Solow-modellel foglalkozik, azonban elötte még röviden ismertetek néhány más olyan modellt, amely a rögzített tényezőarányok feltevésére épül.

A Harrod-Domar-modellel mutat közgazdasági rokonságot Kaldor (1957) modellje is. Szemben a később bemutatott (például a neoklasszikus) növekedési modellekkel, ez sem egy „hagyományos” termelési függvényre épül, hanem feltételezi, hogy a kibocsátás bővülése két tényezőre vezethető vissza: egyrészt egy autonóm elemre (technológiai fejlődés), másrészt a tőkeállomány bővülésére. A beruházásokra pedig egyrészt a kibocsátásra, másrészt a tőkemegtérülésre vonatkozó várakozások

\footnotetext{
${ }^{13}$ Ahogy Domar (1952, p. 492) bemutatja, - a formális modell egyenletein kívül - léteznek stabilizáló mechanizmusok, amelyek vissza tudják állítani a gazdaságot az egyensúlyi növekedési pályára: ilyen például a megtakarítási ráta megváltozása, illetve az a tény, hogy a beruházási döntések nem csak a kapacitás-kihasználtságtól függnek.
} 
hatnak (mindkettő esetében a korábbi időszak tapasztalatai alapján). A megtakarítások és beruházások egyenlőségéből - néhány kiegészítő feltétellel - levezethető az az egyensúlyi növekedési ütem, amely mellett a kibocsátás és a tökeállomány is azonos arányban bővül.

Bár időrendben később következne, de bizonyos értelemben ide kapcsolódik a fizetésimérleg-korlátos növekedési modellek családja is. (Thirlwall, 2011) Ugyanis e modellek sem a termelési függvény által megjelenített kínálati oldalra helyezik a hangsúlyt, hanem a keresleti oldal kerül a középpontba. Az alapmodell három összefüggésböl indul ki:

(1) a folyó fizetési mérlegnek a fenntarthatóság érdekében egyensúlyban kell lennie;

(2) az exportkereslet a reálárfolyam és a külföld jövedelmének függvénye;

(3) az importkereslet a reálárfolyam és a hazai jövedelem függvénye.

Ezek alapján levezethető az az elérhető növekedési ütem, ami összhangban van a folyó fizetési mérleg egyensúlyával. Ha a reálárfolyam konstans, akkor ez a $g=x / \pi$ összefüggést adja, ahol $x$ az export növekedési üteme, $\pi$ pedig az importkereslet jövedelemrugalmassága. (i.m., pp. 321-323)

A modell kiegészíthető a tőkeáramlásokkal, hiszen a folyó mérleg hiányát működőtőke-beáramlás finanszírozhatja. A teljes fizetési mérleg egyensúlyát fenntartó növekedési ütem így felbontható a cserearányok változásának, a külföldi jövedelem és exportkereslet változásának, illetve a tőkebeáramlás változásának hatására. Ha a reálárfolyam konstans, akkor itt is a fentihez hasonló eredmény adódik: az export és a tőkebeáramlás növekedése növeli, az importkereslet magasabb jövedelemrugalmassága csökkenti a fenntartható növekedési ütemet. (i.m., pp. 332-333)

Mivel a fejezet későbbi részében bemutatott modellek döntően más irányt követnek (általában aggregált termelőszektort feltételeznek), ezért csak röviden, de szólni kell a többszektoros gazdaságmodellek növekedéselméleti vonatkozásairól is.

Elsőként Neumann (1945-1946) általános egyensúlyi modelljét említem, melyre az egész lineáris tevékenységelemzési modellirányzat kiindulópontjaként tekinthetünk. A modell által leírt gazdaságban $n$ féle termék szerepel, melyeket különböző eljárásokkal (összesen $m$ félével) lehet előállítani. Ezek az eljárások javak termelését jelentik javak felhasználásával, vagyis az egyes termékek bizonyos eljárások ráfordítási, más eljárások kibocsátási oldalán jelennek meg (elképzelhető az is, hogy mindkettőn). Egyidőszakos termelési ciklusok vannak, ami azt jelenti, hogy az adott 
időszakban kibocsátott termékeket a következő periódusban lehet felhasználni a termelés során. Van technológiai választék és ikertermelés, azaz egy-egy terméket több különböző eljárással is elő lehet állítani, és egy eljárás többféle termék kibocsátását is eredményezheti. A modell linearitása abban áll, hogy az egyes eljárásokban felhasznált és kibocsátott termékek fajlagos mennyisége állandó, vagyis $r_{i j}$ és $z_{i j}$ konstans együtthatók mutatják meg, hogy a $j$-edik termelési folyamatban mennyit használnak fel, illetve mennyit bocsátanak ki az $i$-edik termékből.

Így az $i$-edik termék teljes kibocsátása $\sum_{j=1}^{m} z_{i j} \cdot x_{j}$, a teljes termelő felhasználás belőle pedig $\sum_{j=1}^{m} r_{i j} \cdot x_{j}$, ahol $x_{j}$ mutatja a $j$-edik eljárás alkalmazási mennyiségét. Mivel a következő periódusban a jelen időszaki kibocsátás használható fel a termelési folyamat bemeneti oldalán, ezért az arányos (a termelési szerkezetet nem megváltoztató) gazdasági növekedés legnagyobb lehetséges értékét az határozza meg, hogy az egyes termékek esetén felírt összkibocsátás/összfelhasználás arányok közül melyik a legkisebb:

$$
1+g=\min _{i} \frac{\sum_{j=1}^{m} z_{i j} \cdot x_{j}}{\sum_{j=1}^{m} r_{i j} \cdot x_{j}}
$$

Ez a jószág lesz ugyanis a szük keresztmetszet, ami miatt nem valósítható meg nagyobb ütemü, arányos növekedés. (i.m., p. 4) ${ }^{14}$

A Leontief-féle input-output modell a lineáris tevékenységelemzési modellcsalád speciális esetének tekinthető: nincs technológiai választék és ikertermelés. Ez úgy is megfogalmazható, hogy nem termékek és termelési eljárások vannak, hanem szektorok. Minden ágazatnak van egy outputja, és ráfordításként felhasználja más

${ }^{14}$ Azok a termékek, amelyek esetében ennél nagyobb a kibocsátás és ráfordítás aránya, szabad javakká válnak (hiszen a szük keresztmetszet miatt a gazdaság nem használja fel a teljes, előző időszaki kibocsátást belölük), így áruk nullára csökken. Ez azt is jelenti, hogy a növekedési ütem felírható így is:

$$
1+g=\frac{\sum_{i=1}^{n}\left(\sum_{j=1}^{m} z_{i j} \cdot x_{j}\right) \cdot p_{i}}{\sum_{i=1}^{n}\left(\sum_{j=1}^{m} r_{i j} \cdot x_{j}\right) \cdot p_{i}}
$$

ahol $p_{i}$ az $i$-edik termék ára. (Neumann, 1945-1946, p. 5) 
ágazatok kibocsátását. A módszertan lényegét Leontief (1986) foglalja össze. Az input-output modellek különböző fajtáit különböztethetjük meg, ezek közül a zárt, stacionárius modell felel meg a fentebb említett Neumann-modellnek. Zártnak azokat az input-output modelleket nevezzük, amelyekben nincs külön végső felhasználás, hanem például a háztartási szektor is ugyanúgy szerepel a többi ágazat között, mint a termelő szektorok. A modell stacionaritása pedig azt jelenti, hogy egyrészt több időszak közötti kapcsolatok is szerepelnek benne, hiszen egy adott időszak termelési folyamataihoz nem csak folyó termelö felhasználásra van szükség, hanem a korábbi időszakban felhalmozott tőkére is, másrészt viszont a termelés struktúrája, az egyes szektorok egymáshoz viszonyított súlya nem változik.

A zárt, stacionárius modell a következőképpen írható fel a legegyszerübb formában: $r_{i j}$ jelöli a $j$-edik szektor termelő felhasználását, $b_{i j}$ pedig a $j$-edik szektor tőkeigényét az $i$-edik ágazat kibocsátásából. E jelölésekkel a következő egyenlőségnek kell teljesülnie minden termékre:

$$
x_{i}=\sum_{j=1}^{n} r_{i j} \cdot x_{j}+\sum_{j=1}^{n} b_{i j} \cdot g \cdot x_{j}=\sum_{j=1}^{n} r_{i j} \cdot x_{j}+g \cdot \sum_{j=1}^{n} b_{i j} \cdot x_{j},
$$

vagyis a kibocsátásnak fedeznie kell a folyó felhasználás mellett a termelésnövekedés beruházás-igényét is. ${ }^{15}$ Mátrix-jelölésekkel ez felírható

$$
\mathbf{x}=\mathbf{R} \mathbf{x}+g \mathbf{B} \mathbf{x}
$$

formában, ahol $\mathbf{R}$ a folyó ráfordítási együtthatók, $\mathbf{B}$ a beruházási együtthatók mátrixa. Ez egyszerü átalakítással

$$
(\mathbf{E}-\mathbf{R}) \mathbf{x}=g \mathbf{B} \mathbf{x}
$$

alakra hozható, ahol $\mathbf{E}$ az egységmátrix. Ez utóbbi forma pedig az

$$
\frac{1}{g} \mathbf{x}=(\mathbf{E}-\mathbf{R})^{-1} \mathbf{B} \mathbf{x}
$$

sajátérték-feladatot eredményezi, amiböl következik, hogy a modell stacionárius növekedési üteme $(g)$ egyenlő az $(\mathbf{E}-\mathbf{R})^{-1} \mathbf{B}$ mátrix domináns sajátértékének reciprokával. (Zalai, 2000, pp. 549-550)

Mind Neumann, mind Leontief modelljére igaz, hogy a gazdaság elérhető legnagyobb növekedési ütemét a technológiai színvonal adja meg (illetve az elérhető technológia által meghatározott ráfordítási, kibocsátási, illetve beruházási együtthatók).

\footnotetext{
${ }^{15}$ A következő időszakban a jelenleginél $g \cdot x_{j}$-vel többet termelnek a $j$-edik ágazat termékéböl, ehhez az $i$-edik termékböl $b_{i j} \cdot g \cdot x_{j}$ nettó beruházásra van szükség.
} 
Érdemes kiemelni, hogy a lineáris tevékenységelemzési modell és a Leontiefféle input-output modell rögzített együtthatói szoros közgazdasági rokonságban állnak a Harrod-Domar-modell konstans tőkeegyütthatójával. Ilyen értelemben ezek a Harrod-Domar-modell többszektoros általánositásának is tekinthetők. ${ }^{16}$ Egy szektor esetén az input-output modell alapegyenlete a következő formát ölti:

$$
x=r \cdot x+b \cdot g \cdot x,
$$

amiből

$$
g=(1-r) / b .
$$

Az $(1-r)$ ebben a megközelítésben nem más, mint a megtakarítási ráta, míg $b$ egyszerüen a kibocsátás állandó tőkeigényének felel meg. Így visszakapjuk az egyensúlyi növekedési ütemet meghatározó, Harrod-féle $g=s / b$ egyenlőséget. (Móczár, 2008, p. 499)

Megjegyzem, hogy a többszektoros modellek között is léteznek nemlineáris, vagyis a termelési tényezök közötti helyettesítést megengedő modellek. Solow és Samuelson (1953) például egy olyan modellt mutat be, mely párhuzamba állítható az input-output modellekkel abban a tekintetben, hogy nincs technológiai választék és ikertermelés, viszont a tényezö-felhasználási arányok nem rögzítettek, hanem első fokon homogén (állandó mérethozadékú) termelési függvények írják le az egyes szektorok kibocsátását. A szerzők bemutatják, hogy a modellben létezik olyan egyértelmű stabil és kiegyensúlyozott növekedési pálya, melyen a gazdaság bővülni tud anélkül, hogy a termelési arányok megváltoznának. A fentebbi modellekhez hasonlóan ennek a kiegyensúlyozott növekedési ütemnek az értékét a termelési függvények (vagyis tulajdonképpen a technológiai színvonal) határozzák meg.

\subsection{A Solow-modell - endogén tőkefelhalmozás, exogén technológia}

A Solow-féle növekedési modell mind a mai napig alapvető jelentőséggel bír a közgazdaságtani (azon belül növekedéselméleti) oktatásban. Népszerüségét annak köszönheti, hogy egyszerüsége ellenére is megfogalmazhatók segítségével alapvető jelentőségủ állitások. Természetesen ezzel együtt nem mondhatjuk, hogy a modell

\footnotetext{
${ }^{16}$ A Harrod-Domar-féle $Y=\kappa \cdot K$ termelési függvény értelmezhető úgy is, mint egy kéttényezős, tökéletes kiegészítő (Leontief-féle) termelési függvény egyik ,ága”: ha ez $Y=\min (\kappa \cdot K ; \lambda \cdot L)$ alakú, és a két tényező közül a tőke a szük keresztmetszet (vagyis munkaerő-felesleg, munkanélküliség áll fenn), akkor ez visszaadja az $Y=\kappa \cdot K$ összefüggést.
} 
minden következtetése helytálló lenne. A későbbiekben kitérek a modell eredményei és az empirikus megfigyelések között húzódó néhány ellentmondásra.

A modell gyakorlatilag minden makroökonómiai tankönyvben megtalálható, és a tankönyvi változat némileg eltér az eredetitől, itt azonban egyelöre a Solow (1956) tanulmányában szereplő változatot ismertetem.

A modell egy aggregált termelési függvényre épül:

$$
Y=F(K ; L),
$$

vagyis az egyetlen kompozit jószágot tőke és munkaerő felhasználásával lehet előállítani. ${ }^{17}$ A két termelési tényező között van helyettesíthetőség, szemben a HarrodDomar-, vagy Leontief-féle megközelítéssel. Azonban ez nem szabad, hogy elfedje azt, hogy a termelési tényezők között kiegészítő jellegű kapcsolat is van. Rövid távon ez utóbbi dominál, a helyettesíthetőség annál erőteljesebb, minél hosszabb időtávot vizsgálunk. A termelési függvény konkrét alakja dönti el, hogy inkább a kiegészítő, vagy inkább a helyettesítő viszony a fontos.

A tőkefelhalmozás ugyanennek a kompozit jószágnak a felhalmozását jelenti, vagyis a tőkeállomány növekedése abból fakad, hogy a megtermelt mennyiség egy részét nem fogyasztják el a társadalom tagjai:

$$
\dot{K}=s \cdot Y,
$$

ahol $s$ a konstans megtakarítási ráta. A munkaerö-állomány egy exogén növekedési pályát követ, bővülési üteme $n$, vagyis

$$
L(t)=L(0) \cdot e^{n \cdot t} .
$$

A termelési függvényről azzal a feltevéssel élünk, hogy első fokon homogén, vagyis konstans mérethozadékú. Ez akként is megfogalmazható, hogy nincsen olyan termelési tényező, amelynek mennyisége állandó lenne, és így korlátozná a többi input termelékenységét (ilyen lenne tipikusan a föld). A termelési függvényt behelyettesítve a tökefelhalmozási egyenletbe, megkapjuk azt a differenciálegyenletet, amely a kiinduló helyzet függvényében meghatározza a gazdaság tőkeállományának alakulását:

$$
\dot{K}=s \cdot F\left(K ; L(0) \cdot e^{n \cdot t}\right) .
$$

\footnotetext{
${ }^{17}$ Az eredeti modellben $Y$ a nettó kibocsátást jelenti, vagyis az amortizálódó tőke pótlásán felüli termelést. A tankönyvi modellváltozatban (lásd például Mankiw, 1999) ezzel szemben bruttó kibocsátás szerepel, és az amortizáció explicit módon megjelenik. Ennek részben az is az oka, hogy így jobban tesztelhető a modell (a GNP idősorok közvetlenebbül rendelkezésre állnak, mint az NNP adatok).
} 
A modell az egy före jutó tőkeállományra építve is felírható. Legyen $k=$ $K / L$, vagyis az egy munkásra, vagy teljes foglalkoztatottság esetén egy före jutó tőkeállomány. ${ }^{18}$ Ez azt is jelenti, hogy

$$
\dot{k} / k=\dot{K} / K-\dot{L} / L
$$

Egyrészt felhasználhatjuk, hogy $\dot{K}=s \cdot F(K ; L)$, másrészt hogy $\dot{L} / L=n$. Ezek alapján az egy főre jutó tőkeállomány dinamikáját meghatározó differenciálegyenlet a következő:

$$
\dot{k}=k \cdot(s \cdot F(K ; L) / K)-n \cdot k .
$$

A termelési függvény első fokú homogenitásából következik, hogy

$$
F(K ; L)=L \cdot F(k ; 1)=L \cdot f(k),
$$

ahol $f$ jelöli a termelési függvény ún. intenzív alakját. Ezt felhasználva a differenciálegyenlet végleges alakja a következö:

$$
\dot{k}=k \cdot(s \cdot L \cdot f(k) / K)-n \cdot k=s \cdot f(k)-n \cdot k .
$$

A rendszer akkor van egyensúlyban, ha az egy főre jutó tőkeállomány (a tőke-munka arány) nem változik a gazdaságban, vagyis $\dot{k}=0$. Az egyensúlyi tőkeállományt ez alapján az

$$
s \cdot f\left(k^{*}\right)=n \cdot k^{*}
$$

összefüggés adja meg. ${ }^{19,20}$ (i.m., pp. 66-70)

Ha a termelési függvényre vonatkozóan élünk azokkal az alapvető feltevésekkel, hogy

(1) töke nélkül nincs termelés, vagyis $f(0)=0$,

(2) a tőke határterméke pozitív, de csökkenö, vagyis $f^{\prime}(k)>0$ és $f^{\prime \prime}(k)<0$,

(3) a tőke határterméke 0 és $\infty$ között minden értéket felvesz, vagyis $\lim _{k \rightarrow 0} f^{\prime}(k)=\infty$ és $\lim _{k \rightarrow \infty} f^{\prime}(k)=0$ (ezt nevezzük Inada-feltételnek),

\footnotetext{
${ }^{18}$ Solow (1956) eredeti tanulmányában $r$ jelöli a tőke-munka arányt, vagyis az egy főre jutó tőkeállományt, de Solow (1957) már a $k$ jelölést használja, és azóta is ez az elterjedt a szakirodalomban.

${ }^{19}$ Ezt az összefüggést úgy is értelmezhetjük, mint amely egy före vetített mennyiségekben a tényleges beruházás és a töke-munka arány fenntartásához szükséges beruházás egyenlöségét mondja ki. Ha ugyanis a munkaerö-állomány $n$ ütemben bővül, akkor a tőkeállománynak is ilyen ütemben kell növekednie ahhoz, hogy az egy före jutó tőkeállomány értéke ne változzon.

${ }^{20}$ Ahogy azt korábban említettem, Solow (1956) tanulmányában a kibocsátás az amortizálódó tőke visszapótlása feletti nettó kibocsátást jelenti. A modellt bemutató tankönyvek ezzel szemben az értékcsökkenést explicit módon megjelenítik. Ebben az esetben az egyensúlyfeltétel

$$
s \cdot f\left(k^{*}\right)=(\delta+n) \cdot k^{*},
$$
}

ahol $\delta$ jelöli az amortizációs rátát. 
akkor az egyensúlyi tőke-munka arány egyértelmüen meghatározható. Függetlenül a gazdaság kiinduló állapotától, mindenképpen az egyensúlyi érték felé tart az egy före jutó tőkeállomány. Ami nagyon fontos különbség tehát a Harrod-Domar-modellhez képest, az az, hogy ez az egyensúlyi pálya stabil.

\section{2. ábra: A Solow-modell egyensúlya}

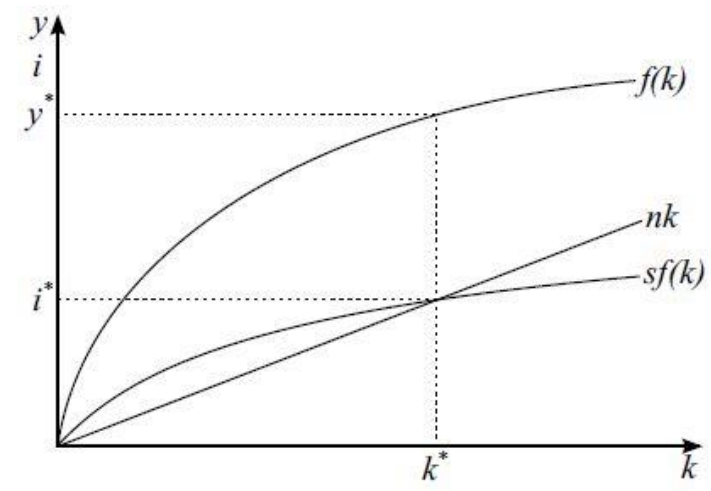

Saját szerkesztés Solow (1956) 1. ábrája alapján

A modell egyensúlyát mutatja a 2. ábra: a vízszintes tengelyen az egy före jutó tőkeállomány $(k)$, a függőleges tengelyen az egy före jutó jövedelem $(y)$ és beruházás $(i)$ szerepel. Az egyensúlyi tőkeállományt a tényleges beruházás és a tőkemunka arány szinten tartásához szükséges beruházás egyenlősége határozza meg, ez viszont egyértelmủen megadja az egy főre jutó jövedelem és beruházás (valamint értelemszerűen a fogyasztás) egyensúlyi szintjét. Ha a kiinduló tőkeállomány $k^{*}$-nál kisebb, akkor a tényleges beruházás $(s \cdot f(k))$ meghaladja azt a mennyiséget, ami az egy före jutó tőkeállomány szintjének fenntartásához szükséges volna $(n \cdot k)$. Ennek eredményeként javul a tőkeellátottság. A $k^{*}$-nál nagyobb kezdeti tőkeállomány esetén ezzel ellentétes folyamat zajlik le: a megvalósuló beruházás nem elegendő az egy före jutó tőkeállomány szinten tartásához. Minden $k<k^{*}$ esetben növekszik, minden $k>k^{*}$ esetben csökken a tőkeellátottság, vagyis bármilyen kiinduló állapot esetén az egyensúly felé konvergál a gazdaság. Ez egyben az egyensúly stabilitását is eredményezi, hiszen ha valami kimozdítja a rendszert az egyensúlyi helyzetböl, a fentebb leírt mechanizmus azonnal visszafelé tereli azt.

Solow (1956) tanulmányának végén a modell több kiterjesztését (például reálbértől függő munkakínálat, kamatlábtól függő megtakarítási ráta) is tárgyalja. Ezek közül a leglényegesebb az exogén technológiai fejlődés beépítése a modellbe. Ez azt 
jelenti, hogy a termelési függvényben megjelenik egy, a technológiai fejlettséget leíró $A$ változó, amelyről azt feltételezzük, hogy konstans $g$ ütemben növekszik, vagyis

$$
A(t)=A(0) \cdot e^{g \cdot t}
$$

Így a termelési függvény az

$$
Y=A \cdot F(K ; L)
$$

alakot ölti. A modell dinamikája ebben az esetben is meghatározható, a lényegi különbség az lesz az alapváltozathoz képest, hogy technológiai fejlődés esetén az egy före jutó tőkeállománynak nem lesz egyensúlyi értéke, hanem ehelyett egy olyan egyensúlyi pályához konvergál a gazdaság, amelyen ez a tőkeellátottság (és így az egy före jutó jövedelem) folyamatosan nő. ${ }^{21}$ Újabb fontos különbség a HarrodDomar-modellhez képest, hogy a megtakarítási ráta csak az egyensúlyi pálya szintjét befolyásolja, a gazdaság egyensúlyi növekedési ütemét nem, az csak a technológiai fejlődés ütemétől függ. ${ }^{22}$ (i.m., pp. 85-86)

Azzal együtt, hogy a Solow-modell nagyon hasznos kiindulási és viszonyítási alapnak tekinthető a későbbi évtizedek növekedési modelljei, elméletei szempontjából, illetve egyszerüsége ellenére is fontos szempontokra hívja fel a figyelmet (a beruházások és a megtakarítás jelentőségének megkerülhetetlensége, a népességnövekedés szerepe), több fontos tekintetben is ellentmondás figyelhető meg a modell következtetései és az empirikus tapasztalatok között. Néhány ilyen empirikus problémára Romer (2001, pp. 26-28) is felhívja a figyelmet.

A Solow-modell egyetlen endogén változója a tőkeellátottság. Ez azonban nem tudja megmagyarázni azokat a különbségeket, amelyek az egyes országok fejlettségi színvonalában tapasztalhatók. Az egyszerüség kedvéért tegyük fel, hogy munkakiterjesztő technológiai haladás és állandó mérethozadékú, Cobb-Douglastípusú termelési függvény írja le a gazdaságok müködését:

\footnotetext{
${ }^{21}$ Noha a technológiai fejlődést is feltételező Solow-modell egyensúlyi növekedési pályája is stabil (vagyis egy sokk után a növekedési ütem visszakonvergál az egyensúlyi szinthez), Sato (1964) megmutatja, hogy az egyensúlyi pályára való visszatérés nagyon lassan következik be.

${ }^{22} \mathrm{Az}$ eredeti tanulmányban semleges (azóta elterjedt elnevezéssel Hicks-semleges) technológiai fejlödés szerepel, a modellt bemutató későbbi tankönyvek ezzel szemben többnyire munkakiterjesztő (más néven Harrod-semleges) technológiai fejlödést tartalmaznak:

$$
Y=F(K ; A \cdot L) \text {. }
$$

Utóbbi esetben az egy före jutó tőkeállomány és jövedelem bővülési üteme az egyensúlyi növekedési pályán pontosan megegyezik a technológia fejlödésének ütemével. Cobb-Douglas-típusú termelési függvény és Hicks-semleges technológiai fejlődés $\left(Y=A \cdot K^{\alpha} \cdot L^{1-\alpha}\right)$ esetében az egy före jutó tőkeállomány növekedési üteme $g /(1-\alpha)$, az egy före jutó jövedelem növekedési üteme $\alpha \cdot g /(1-\alpha)$ az egyensúlyi pályán. (Solow, 1956, p. 85)
} 


$$
Y=K^{\alpha} \cdot(A \cdot L)^{1-\alpha} .
$$

Ebben az esetben a termelési függvény intenzív (a technológiai fejlődés miatt itt már nem egy före, hanem egy munkahatékonysági egységre vonatkozó mennyiségekben kifejezett) formája az $y=k^{\alpha}$ alakot ölti. Az $\alpha$ paraméter egyfelől az egy hatékonysági egységre jutó kibocsátásnak a tőkeellátottság szerinti rugalmasságát jelenti, másfelől - a termelési függvény állandó mérethozadéka miatt - ez adja meg a tőkejövedelmek részesedését is az összkibocsátásból. ${ }^{23}$ Ezt a részesedést általában egyharmad körüli értékre szokták becsülni az empirikus vizsgálatok. Ez viszont azt jelenti, hogy ha az Egyesült Államok egy hatékonysági egységre jutó kibocsátása mintegy tízszerese az indiainak, akkor ahhoz, hogy ez a tízszeres különbség kialakulhasson a tőkeellátottságban mutatkozó eltérés eredményeként, az amerikai egy hatékonysági egységre jutó tőkeállománynak az indiai ezerszeresének kellene lennie. ${ }^{24}$ Ekkora különbség viszont nincs a két ország (illetve természetesen általánosabban a gazdagabb és szegényebb országok) között.

Ugyanígy a tőkeellátottság magyarázó erejének korlátaira hívja fel a figyelmet az is, ha a tökemegtérülési rátákat vizsgáljuk. A fentebb is használt CobbDouglas-függvényforma esetén a tőke határterméke

$$
f^{\prime}(k)=\alpha \cdot k^{\alpha-1}=\alpha \cdot y^{\frac{\alpha-1}{\alpha}} .
$$

Vagyis a tőke határtermékének az egy hatékonysági egységre jutó kibocsátás szerinti rugalmassága $(\alpha-1) / \alpha$. Ha a tőkejövedelmek részesedését továbbra is egyharmadnak tekintjük, akkor ennek a rugalmasságnak az értéke -2. Ez alapján a fentebbi példánál maradva a tőke határtermékének Indiában százszor nagyobbnak kellene lennie, mint az Egyesült Államokban. ${ }^{25}$ Mivel a tőkemegtérülési ráta a határtermék és az amortizációs ráta különbségeként adódik, ezért abban még nagyobb különbségnek kellene mutatkoznia a két ország között. Ez hatalmas mértékü tőkeáramlást kellene,

${ }^{23}$ Állandó mérethozadékú $Y=F(K ; A \cdot L)$ termelési függvény esetén az Euler-tétel értelmében teljesül az az egyenlöség, hogy

$$
Y=M P_{K} \cdot K+M P_{L} \cdot A \cdot L,
$$

vagyis a teljes kibocsátás felosztható a termelési tényezők tulajdonosainak jövedelmeire. A tőkejövedelmek részesedése $M P_{K} \cdot K / Y$, és a Cobb-Douglas-esetben ez nem más, mint

$$
M P_{K} \cdot K / Y=\alpha \cdot K^{\alpha-1} \cdot(A \cdot L)^{1-\alpha} \cdot K / Y=\alpha .
$$

${ }^{24}$ Ha $y_{U S A}=10 \cdot y_{\text {India }}$, akkor a termelési függvény intenzív alakjának felhasználásával a következöt kapjuk:

${ }^{25}$ Az elöző lábjegyzetben szereplö levezetéshez hasonlóan:

$$
k_{U S A}=y_{U S A}^{\frac{1}{\alpha}}=\left(10 \cdot y_{\text {India }}\right)^{\frac{1}{\alpha}}=10^{\frac{1}{\alpha}} \cdot y_{\text {India }}^{\frac{1}{\alpha}}=10^{\frac{1}{\alpha}} \cdot k_{\text {India }} .
$$

$$
f^{\prime}\left(k_{U S A}\right)=\alpha \cdot y_{U S A}^{\frac{\alpha-1}{\alpha}}=\alpha \cdot\left(10 \cdot y_{\text {India }}\right)^{\frac{\alpha-1}{\alpha}}=10^{\frac{\alpha-1}{\alpha}} \cdot \alpha \cdot y_{\text {India }}^{\frac{\alpha-1}{\alpha}}=10^{\frac{\alpha-1}{\alpha}} \cdot f^{\prime}\left(k_{\text {India }}\right) .
$$


hogy eredményezzen az Egyesült Államok felöl India irányába, lényegesen nagyobbat, mint ami a valóságban megfigyelhető.

Azt is érdemes megemlíteni, hogy a Solow-modellben az egyes országok a saját egyensúlyi növekedési pályáikhoz tartanak, vagyis feltételes konvergencia valósul meg: hosszú távon eltűnnek a jövedelmi különbségek két ország között, ha a gazdaságok hasonló jellemzőkkel (termelési függvény, megtakarítási ráta, egyéb paraméterek) írhatók le. Ráadásul mivel a szegényebb országokban a tőke megtérülése magasabb, ezért (ha adminisztratív vagy egyéb korlátok ezt nem akadályozzák) beindul a tőkeáramlás a gazdagabb országokból a szegényebbek felé, vagyis idővel eltünnek a tőkeellátottságban korábban meglévő különbségek. Ez azt jelenti, hogy nyitott gazdaságok, szabad tőkeáramlás esetén még erősebb következtetés adódik a Solow-modellböl: hosszú távon abszolút konvergencia következik be, vagyis folyamatosan csökkennek az országok közötti jövedelmi különbségek. Bár feltételes konvergencia általában kimutatható az ökonometriai vizsgálatokkal (lásd a 3.4. alfejezetet), az abszolút konvergencia nyilvánvalóan nem felel meg az empirikus megfigyeléseknek. ${ }^{26}$ Noha az országok bizonyos csoportjain belül (tipikusan ilyenek a mai fejlett gazdaságok) megfigyelhetünk konvergenciát, az országok szélesebb körét vizsgálva már egyáltalán nem látható ilyen egyértelmű minta. Inkább beszélhetünk egyfajta klubkonvergenciáról: országok egyes csoportjain belül csökkennek a különbségek, míg e között a csoportok között növekednek. (Quah, 1996, Ben-David, 1997)

Végül ki kell emelni két elvi problémát is. Az egyik a konstans mérethozadék feltevéséhez kapcsolódik. Ahogy fentebb volt róla szó, ebböl az is következik, hogy a gazdaságban termelődő jövedelmek egyértelmüen feloszthatók a tőke- és munkajövedelmek között. Ahogy azonban azt Solow (2015) is elismeri, emellett a valóságban keletkeznek járadékjellegű, vagyis a befektetett erőforrások normál megtérülése feletti jövedelmek is. Ha ezek a járadékok nagyjából állandó arányban oszlanak meg a tőke és munkaerő tulajdonosai között, akkor elosztási szempontból nem tekinthető kritikus egyszerüsítésnek az állandó mérethozadék feltételezése. ${ }^{27}$ Viszont az egyen-

\footnotetext{
${ }^{26} \mathrm{Ez}$ az ellentmondás természetesen nem csak a Solow-modell problémájaként értelmezhető, hanem a tőkeáramlások korlátai is okozhatják.

${ }^{27}$ Solow (2015) pont azzal foglalkozik, hogy az elmúlt évtizedekben társadalmi és gazdasági változások (például a szakszervezetek gyengülése) miatt a járadékokból való részesedés arányai lényegesen eltolódtak a tőke javára.
} 
súlyi növekedési pályára vonatkozó következtetések szempontjából kulcsfontosságú feltevésről van szó, ezért a járadékok léte a modellt alapjaiban kérdőjelezi meg.

A másik elvi probléma az, hogy az állandósult állapot (az egyensúlyi növekedési pályák) elérése után a Solow-modell gazdaságaiban az egy före jutó jövedelem bővülési ütemét a technológiai fejlődés sebessége határozza meg. A modellben ez tehát a hosszú távú, stabil növekedés végső forrása, azonban a modellben a technológiai fejlödés exogén változóként jelenik meg. Ahogy fentebb láttuk, az egyetlen endogén változó, vagyis a tőkeellátottság nem képes magyarázni az egyes országok közötti fejlettségbeli különbségeket, vagy akár a gazdasági növekedés időbeli alakulását, a hosszú távú növekedést meghatározó technológiai fejlődésről viszont a modell érdemben nem mond semmit. A fejezet későbbi részében rátérünk olyan modellekre, amelyek endogenizálják a technológiai fejlődést, azonban előbb még néhány más olyan elméletről kell szót ejteni, amelyek a Solow-modell más feltevéseit oldják.

\subsection{További neoklasszikus növekedési modellek}

A Solow-modell kapcsán felvethető egyik fontos kritikai észrevétel, hogy a modellben a megtakarítási ráta exogén paraméterként szerepel, vagyis nincs mögötte optimalizáló fogyasztói magatartás. Természetesen léteznek olyan neoklasszikus modellek, amelyekben szerepel ez a mikroökonómiai megalapozás is.

E modellek gyökerei Ramsey (1928) klasszikus tanulmányáig vezetnek viszsza. A cikk azt a kérdést vizsgálja, hogy egy végtelen ideig müködő (változatlan népességszámú, és technológiai fejlődést nem tapasztaló) gazdaságban mekkora megtakarítási ráta mellett éri el a társadalom a maximális hasznosság szintjét. A modell két olyan egyszerüsítő feltevéssel él, amely a későbbiekben meglehetősen széles körben elterjedt: egyrészt aggregált termelőszektorral és egy aggregált termelési függvénnyel írja le a gazdaság müködését, másrészt (noha ez így ebben a formában nincs kimondva) a reprezentatív döntéshozó végtelen időhorizonton optimalizál. A modell harmadik feltevése az, ami a mai olvasó számára szokatlanabb: a gazdaság előbbutóbb elér (vagy legalábbis aszimptotikusan megközelít) egy olyan fogyasztási szintet, amely a hasznosság elérhető legmagasabb szintjét eredményezi (ezt nevezi 
Ramsey a „bliss”, vagyis üdvözülés állapotának). ${ }^{28}$ Ez tulajdonképpen azt jelenti, hogy ennél a szintnél a fogyasztás határhaszna nullává válik. ${ }^{29}$

A cél tehát az, hogy a gazdaság egy optimális pályán eljusson a maximális hasznosságot eredményező idilli állapotba, és onnantól kezdve folyamatosan ezt a fogyasztási szintet tartsa fenn. Levezethető, hogy ehhez mekkora megtakarítási rátára van szükség: a Ramsey (1928) által meghatározott szabály szerint a tőkefelhalmozási ütemnek és a fogyasztás határhasznának szorzata meg kell, hogy egyezzen azzal a különbséggel, ami a maximális elérhető hasznosság és a jelenlegi hasznosság között fennáll. Vagyis

$$
\dot{K}(t) \cdot M U_{C}(C(t) ; L(t))=\max (U(C ; L))-U(C(t) ; L(t)),
$$

ahol $C$ a fogyasztás, $L$ pedig a munka mennyisége, melyek közül elöbbi értelemszerüen növeli, utóbbi csökkenti a hasznosságot. (i.m., p. 547)

Két megjegyzés kívánkozik ide. Egyrészt látható, hogy a modell kardinális hasznosság-megközelitést alkalmaz, ami a későbbi modellekre már egyáltalán nem jellemző. Másrészt az optimumfeltétel alapján nem tudunk egyértelmü megállapítást tenni a $\dot{K}(t)$ függvény alakjára vonatkozóan: ahogy az idő előrehaladtával nő a tőkeállomány és így a kibocsátás, valamint a fogyasztás, egyfelől úgy kerül egyre közelebb a gazdaság az üdvözülés állapotához, másfelöl pedig úgy csökken a fogyasztás határhaszna. Ezek eredőjeként a $\dot{K}(t)$, vagyis az adott időszaki tőkefelhalmozás értéke növekedhet és csökkenhet is.

Noha a megfogalmazás valamelyest különbözik, a Ramsey-modell logikája szoros kapcsolatban van az ún. „aranyszabály” szerinti növekedéssel. A Phelps (1961) által bevezetett fogalom a Solow-modellre építve határozza meg azt a konstans megtakarítási rátát, amely a legmagasabb, fenntartható fogyasztási színvonalat eredményezi. Cikkében levezeti, hogy konstans mérethozadékú technológia esetén ez a megtakarítási ráta megegyezik a tőkejövedelmeknek a teljes kibocsátásból vett ará-

\footnotetext{
28 Természetesen más modellekben is van maximuma az elérhető hasznosságnak, azonban Ramsey (1928, p. 545) külön ki is mondja, hogy a fogyasztás és egyéb materiális tényezők révén elérhető hasznossági szint eleve korlátos.

${ }^{29}$ Mivel a modellben nem szerepel amortizáció, ezért ha nem 0 a megtakarítási ráta, akkor a tőkeállomány folyamatosan növekszik. Ebböl az is következik, hogy nem csak a fogyasztás határhasznának 0ra csökkenése eredményezheti a maximális hasznosság elérését, hanem az is, ha egy bizonyos tökeállomány elérése esetén a tőke határterméke válik 0-vá.
} 
nyával. (i.m., pp. 641-642.) ${ }^{30}$ Az így kapott, fogyasztás-maximalizáló egyensúlyi tőkeállomány esetén pedig teljesül az $f^{\prime}\left(k^{*}\right)=\delta+n+g$ feltétel.

Koopmans (1965) formálisan is összekapcsolja Ramsey (1928) modelljét az aranyszabály szerinti növekedési pályával. Modelljében nem szerepel technológiai fejlődés, a gazdaság müködését az első fokon homogén $F(K ; L)$ termelési függvény írja le, melyben mindkét termelési tényező nélkülözhetetlen, határtermékük pozitív, de csökkenő. A kibocsátást fogyasztásra, illetve nettó beruházásra lehet fordítani, vagyis

$$
F(K ; L)=C+\dot{K}^{31}
$$

Ha a népesség konstans $n$ ütemben növekszik, akkor az árupiaci egyensúlyfeltétel intenzív alakja az

$$
f(k)=c+\dot{k}+n \cdot k
$$

formát ölti, ahol a jobboldal harmadik tagja azt a beruházás-mennyiséget jelöli, ami ahhoz szükséges, hogy az egy före jutó tőkeállomány ne csökkenjen. Mivel az $f(k)$ függvény a feltevések szerint monoton növő, de konkáv, így minden 0 és $f^{\prime}(0)$ közé eső $n$ népességnövekedési ütemhez tartozik olyan $\bar{k}$ tőkeállomány, amelyre $f(\bar{k})=n \cdot \bar{k}$ és $f(k)>n \cdot k$ minden $k<\bar{k}$ esetén. (Koopmans, 1965, p. 236)

Ami a célfüggvényt illeti, Koopmans morális alapon amellett érvel, hogy a generációk között nem szabad különbséget tenni az egy főre jutó fogyasztás hasznos-

${ }^{30}$ Mindez könnyen belátható a korábbiakban is használt, munkakiterjesztő technológiai fejlődést tartalmazó, Cobb-Douglas-típusú termelési függvény esetén. Ekkor a termelési függvény intenzív alakja $y=k^{\alpha}$. Az egy hatékonysági egységre jutó egyensúlyi tőkeállományt az

feltétel adja meg:

$$
s \cdot\left(k^{*}\right)^{\alpha}=(\delta+n+g) \cdot k^{*}
$$

$$
k^{*}=(s /(\delta+n+g))^{\frac{1}{1-\alpha}} .
$$

Az egy hatékonysági egységre jutó egyensúlyi kibocsátás

a fogyasztás pedig

$$
y^{*}=(s /(\delta+n+g))^{\frac{\alpha}{1-\alpha}},
$$

amit átírhatunk

$$
c^{*}=(1-s) \cdot(s /(\delta+n+g))^{\frac{\alpha}{1-\alpha}}
$$

$$
c^{*}=\left(s^{\frac{\alpha}{1-\alpha}}-s^{\frac{1}{1-\alpha}}\right) /(\delta+n+g)^{\frac{\alpha}{1-\alpha}}
$$

alakba. Mivel a nevező konstans, ezért az optimum megtalálásához elég a számlálót maximalizálni. Ennek elsőrendü feltétele az, hogy

$$
(\alpha /(1-\alpha)) \cdot\left(s^{*}\right)^{\frac{2 \cdot \alpha-1}{1-\alpha}}-(1 /(1-\alpha)) \cdot\left(s^{*}\right)^{\frac{\alpha}{1-\alpha}}=0,
$$

aminek átrendezéséből adódik az $s^{*}=\alpha$ eredmény.

31 Valójában tehát a termelési függvény értéke - Solow (1956) eredeti modelljéhez hasonlóan - az amortizálódó tőke pótlását már nem tartalmazó, nettó kibocsátást adja meg. 
ságát illetően, vagyis az $U_{T}=\int_{0}^{T} u\left(c_{t}\right) d t$ hasznosságfüggvényt vizsgálja, ahogy $T$ végtelenbe tart. Az időszaki $u\left(c_{t}\right)$ hasznosságfüggvényről pedig azzal a feltevéssel él, hogy monoton növő, de szigorúan konkáv. (i.m., pp. 239-241) ${ }^{32}$ Ezek után bebizonyítja, hogy bármely $0<k_{0}<\bar{k}$ kezdeti tőkeállomány esetén a teljes hasznosságot maximalizáló fogyasztási és tőkefelhalmozási pálya véges időszakon belül (alulról vagy felülről) az aranyszabály szerinti $k^{*}$ tőkeellátottsághoz vezet, amelyre igaz, hogy $f^{\prime}\left(k^{*}\right)=n \cdot{ }^{33}$ E tőkeállomány elérése után az életpálya-hasznosságot ennek a szintnek a fenntartása maximalizálja. Az optimális pálya minden pontjára teljesül az

$$
u^{\prime}\left(c_{t}\right) \cdot \dot{k}_{t}=u^{*}-u\left(c_{t}\right)
$$

feltétel, ahol

$$
u^{*}=u\left(f\left(k^{*}\right)-n \cdot k^{*}\right),
$$

vagyis az aranyszabály szerinti tőkeállomány esetén jelentkező időszaki hasznosság. (i.m., pp. 242-243) Ez a feltétel teljes mértékben analóg a Ramsey (1928) cikkében levezetett hasonló feltétellel, a két különbség mindössze az, hogy Koopmans egy före jutó értékeket használ (mivel Ramsey konstans népességet feltételez, így nála ennek nincs jelentősége), illetve hogy itt a hasznosság csak a fogyasztás függvénye, a munka nem szerepel benne.

Koopmans (1965) azt is bemutatja, hogyan változik a kép, ha a későbbi generációk hasznosságát diszkontáljuk, vagyis ha a célfüggvény

$$
U=\int_{0}^{\infty} e^{-\rho \cdot t} \cdot u\left(c_{t}\right) d t \text {-re }
$$

változik, ahol $\rho>0$ a diszkontráta. Ez esetben is létezik és egyértelmü az optimális pálya, azonban ekkor az állandósult állapotban az egy före jutó tőkeállományra az $f^{\prime}\left(k^{*}\right)=n+\rho$ feltételnek kell teljesülnie az $f^{\prime}\left(k^{*}\right)=n$ feltétel helyett. (i.m., p. 247) Mivel a tőke határterméke csökkenő, ezért a diszkontálást tartalmazó esetben az optimális pályához az aranyszabály szerintinél kisebb tőkeállomány (ennek következtében pedig kisebb kibocsátás és fogyasztás) tartozik. Ennek oka, hogy a magasabb későbbi egyensúlyi fogyasztás révén elérhető hasznosságtöbbletet több mint ellensúlyozza az eléréséhez szükséges jelenlegi takarékoskodás által okozott hasznosságveszteség.

\footnotetext{
${ }^{32}$ Mivel a tőke határterméke és a fogyasztás határhaszna is szigorúan pozitív, ezért Koopmans (1965) modelljéből már hiányzik a Ramsey-nél még szereplő telítődés.

${ }^{33}$ Ez természetesen ugyanaz a feltétel, ami fentebb is szerepelt az aranyszabály bemutatásakor, figyelembe véve, hogy Koopmans (1965) modelljében nincs technológiai fejlődés, illetve eltérő az amortizáció kezelése.
} 
Koopmanstól függetlenül, némileg eltérő megfogalmazással (modellje például explicit módon tartalmazza az amortizációt), de azonos eredményekre jutott Cass (1965) is. ${ }^{34}$ Cass (1966) azt vizsgálja, hogyan változnak az eredmények, ha véges időhorizonton optimalizál a döntéshozó. A döntés során figyelembe vett időszakon túli generációk mindössze egy olyan feltétel formájában vannak figyelembe véve, hogy az időszak végén az egy főre jutó tőkeállománynak legalább $k_{T}$ értéket el kell érnie. Ez esetben az optimális életpálya során a tőkeellátottság az időszak első részében monoton módon közeledik a végtelen idöhorizontú modell egyensúlyi értékéhez, azonban az időszak vége felé újra el kezd távolodni töle és $k_{T}$-hez tart. (i.m., pp. 845-846)

Ennek a modellcsaládnak számos további képviselője is van, ezekről Koopmans (1967) ad összefoglalót. Azonban fontos kiemelni, hogy az egyensúlyi növekedési pálya elérése után e modellekben is csak akkor nőhet az egy före jutó kibocsátás, illetve fogyasztás, ha a termelés hatékonysága, a technológia fejlődik. ${ }^{35}$ Erről viszont e modellek sem állítanak semmit, így ebben a tekintetben nem oldják fel azokat az ellentmondásokat, amelyeket a Solow-modellel kapcsolatban említettünk.

A neoklasszikus növekedési modellek egy másik irányát képviselik a Diamond (1965) híres cikkén alapuló együttélő generációs (overlapping generations, OLG) modellek. Ezek legfőképpen abban különböznek a reprezentatív fogyasztós irányzattól, hogy e modellekben nem homogének a döntéshozók.

A modell legegyszerübb változatában minden fogyasztó két időszakig él: az első időszakban dolgozik, munkajövedelmének egy részét elfogyasztja, másik részét pedig befekteti a tőkepiacon. Az életpálya második időszakában ennek a befektetésnek a hozamokkal megnövelt értékét fogyasztják el a szereplők, munkajövedelmük nincs. A feladat tehát a két időszaki fogyasztástól függő $U\left(c_{1, t} ; c_{2, t+1}\right)$ hasznosság ${ }^{36}$ maximalizálása azzal a feltétellel, hogy a fogyasztás jelenértéke nem lehet nagyobb az első időszakban megszerzett munkajövedelemnél:

\footnotetext{
34 Ennek köszönhető a szakirodalomban meghonosodott Ramsey-Cass-Koopmans-modell (Romer, 2001) vagy Cass-Koopmans-Ramsey-modell (Aghion és Howitt, 2009) elnevezés.

${ }^{35}$ Valamint az egyensúlyi növekedési pályán a megtakarítási ráta is konstans, csakúgy, mint a Solowmodellben.

${ }^{36}$ Mivel egy adott időszakban kétféle döntéshozó létezik, az ő megkülönböztetésükre szolgál az 1 és 2 alsó index. A $t$-edik időszakban született generáció tagjának fiatalkori fogyasztása $c_{1, t}$, időskori fogyasztása $c_{2, t+1} \cdot c_{2, t}$ az előző, $(t-1)$-edik időszakban születettek időskori fogyasztását jelölné.
} 


$$
c_{1, t}+\frac{1}{1+r_{t+1}} \cdot c_{2, t+1}=A_{t} \cdot w_{t} \cdot{ }^{37}
$$

A modellcsalád sok különböző közgazdasági probléma vizsgálatára alkalmas, a gazdasági növekedés kérdései szempontjából két fontos jellemvonását emeljük ki. Egyrészt az egyensúlyi növekedési pálya elérése után a tartós gazdasági növekedés egyetlen lehetséges forrása a technológiai fejlödés, amit ez a modell is exogénnak feltételez. Másrészt viszont a modellben a hasznossági és termelési függvény konkrét alakjától és paramétereitől függően akkor is kialakulhat több különbözö állandósult állapot, ha a függvények a szokásosan elvárt feltételeket (pozitív, de csökkenő határhaszon mindkét időszaki fogyasztás szerint, első fokon homogén termelési függvény, pozitív, de csökkenő határtermékek, Inada-feltétel) teljesítik. Ez azt jelenti, hogy a kiinduló állapottól (kezdeti tőkeellátottságtól) függően akár az egyébként hasonló paraméterekkel (diszkontráta, népességnövekedési és technológiai fejlődési ütem) és azonos technológiával rendelkező gazdaságok is eltérő egyensúlyi növekedési pályára állhatnak, vagyis divergálhatnak.

\subsection{A technológiai fejlődés endogén magyarázata}

A neoklasszikus modellek egyik fontos hiányossága, hogy nem képesek endogén módon magyarázni a tartós gazdasági növekedést. Az egyensúlyi növekedési pályához való konvergencia során elért növekedési ütem függ a tőkefelhalmozástól (ami a megtakarítási arány, illetve a diszkontráta függvénye), azonban az egyensúlyi pálya elérése után a neoklasszikus modellekben a növekedés egyedüli forrása a technológiai fejlődés (a termelékenység javulása), ami viszont exogén változóként szerepel. Az endogén növekedési modellek fő célja éppen ennek az egyensúlyi növekedési ütemnek a magyarázata.

Mielőtt rátérnénk a makro-megközelítésű endogén modellekre, a technológiai fejlődés magyarázata kapcsán röviden ki kell térnünk Joseph Schumpeter munkásságára. Ö alapvetően a gazdasági fejlődés mikroszintű alapjaival foglalkozott, és az innovációt, illetve a vállalkozót helyezte elmélete középpontjába. A vállalkozót az különbözteti meg a többi gazdasági alanytól, hogy ő látja el az innoválás (nem feltétlenül a feltalálás, hanem az új találmányok, új eljárások gazdasági bevezetésének) funkcióját, ő az, aki a termelőeszközök eddigiektől eltérő kombinációjával valami

\footnotetext{
${ }^{37} w_{t}$ az egy hatékonysági egységre jutó munkabért jelöli (ami az egyensúlyi növekedési pályán állandó értékre áll be), így egy fogyasztó munkajövedelme $A_{t} \cdot w_{t}$.
} 
újat hoz a piacon. (Schumpeter, 1980 [1934]) Mindezek alapján a gazdasági fejlődés sosem egyenletes, hiszen az innováció eredményeként termelési tényezők áramlanak egyik tevékenységből a másikba, bizonyos vállalatok, gazdasági ágak teljesítménye visszaesik. Vagyis az innováció egyben egy folyamatos megújulással és átrendeződéssel, egy „,teremtő rombolással” jár együtt. (Schumpeter, 1987 [1943])

Az endogén növekedési makromodellek közül a legegyszerübb az úgynevezett $A K$ modell, amely a technológiai fejlődést a tőkefelhalmozás „melléktermékeként” kezeli (,,learning by doing”). ${ }^{38}$ A modell alapváltozatában a termelést véges sok ( $N$ számú) versenyző vállalat végzi, termelési függvényük - a neoklasszikus modellekhez hasonlóan - konstans mérethozadékú, az egyszerüség kedvéért alkalmazhatunk Cobb-Douglas-függvényt:

$$
y_{j}=\bar{A} \cdot k_{j}^{\alpha} \cdot l_{j}^{1-\alpha},
$$

ahol $k_{j}$ és $l_{j}$ a $j$-edik vállalat által felhasznált tőke és munka mennyiségét jelöli, míg $\bar{A}$ a vállalatok számára elérhető, közös technológiai színvonalat. Ez a termelékenység a vállalatok által felhalmozott tőke mennyiségétől függ:

$$
\bar{A}=A_{0} \cdot\left(\sum_{j=1}^{N} k_{j}\right)^{\eta} .
$$

Az egyszerűség kedvéért feltételezzük, hogy a vállalatok egyforma méretűek, mindegyikük egységnyi munkaerőt alkalmaz $\left(l_{j}=1\right)$. Mivel termelési függvényük és méretük azonos, így a vállalatok ugyanazt a tényezőarányt fogják kialakítani, vagyis ugyanannyi tőkét is vonnak a termelésbe:

$$
K=\sum_{j=1}^{N} k_{j}=N \cdot k_{j} .
$$

Így a termelékenységi változót meghatározó összefüggés az $\bar{A}=A_{0} \cdot K^{\eta}$ alakra egyszerüsödik. A vállalatok termelési függvénye

$$
y_{j}=A_{0} \cdot K^{\eta} \cdot(K / N)^{\alpha},
$$

a teljes gazdaság aggregált termelési függvénye pedig

$$
Y=N \cdot y_{j}=N \cdot A_{0} \cdot K^{\eta} \cdot(K / N)^{\alpha}=A_{0} \cdot N^{1-\alpha} \cdot K^{\alpha+\eta} .
$$

\footnotetext{
${ }^{38}$ Az alapötlet Arrow (1962) tanulmányából ered, az itt szereplö egyszerübb modell leírása Aghion és Howitt (2009, pp. 49-52) könyvén alapul. Lucas (1988) egyik modelljében más értelemben jelenik meg a „learning by doing” jelensége: a termelés eredményeképpen mintegy melléktermékként humán tőkét halmoznak fel a dolgozók.
} 
Az $A_{0} \cdot N^{1-\alpha}$ kifejezést az egyszerüség kedvéért $A$-val helyettesítve azt kapjuk, hogy

$$
Y=A \cdot K^{\alpha+\eta} \text {. }
$$

Mivel a korábbiakban láttuk, hogy a Solow-modell fö következtetései nem a konstans megtakarítási arány feltételezésén múlnak, ezért itt is élhetünk ezzel a feltevéssel, vagyis a tőkeállomány növekedését a

$$
\dot{K}=s \cdot Y-\delta \cdot K=s \cdot A \cdot K^{\alpha+\eta}-\delta \cdot K
$$

összefüggés írja le, ami alapján a tőkeállomány bővülési üteme:

$$
\dot{K} / K=s \cdot A \cdot K^{\alpha+\eta-1}-\delta .
$$

Az aggregált termelési függvénynek, és így az egész modellnek a viselkedése az $\alpha+\eta$ összegtől függ, melynek első tagja a tőke saját termelésben megnyilvánuló hozamát mutatja, míg a második tag azt a tovagyürüzö hatást, amelyet a tőkefelhalmozás a többi vállalat számára is hasznosítható termelékenység-növekedésre fejt ki. Ha $\alpha+\eta<1$, akkor a modell kvalitatív következtetései nem különböznek érdemben a Solow-modellétől, hiszen a csökkenő határtermék hatása dominálja a termelékenységet növelő pozitív externáliákat. Ez esetben lesz egy egyértelműen meghatározható egyensúlyi tőkeállomány:

$$
K^{*}=(s \cdot A / \delta)^{\frac{1}{1-\alpha-\eta}},
$$

az egyensúlyi kibocsátás pedig

$$
Y^{*}=A \cdot(s \cdot A / \delta)^{\frac{\alpha+\eta}{1-\alpha-\eta}}=A^{\frac{1}{1-\alpha-\eta}} \cdot(s / \delta)^{\frac{\alpha+\eta}{1-\alpha-\eta}} .
$$

Mivel a modellben nincs népességnövekedés és a tőkefelhalmozástól független technológiai fejlődés, ezért az egyensúly elérése után nincs további gazdasági növekedés.

Ellenben, ha $\alpha+\eta>1$, akkor az externális hatások több mint kompenzálják a termelési függvény eredendő csökkenő mérethozadékát. Ez azt jelenti, hogy a tőkeállomány egyre nagyobb és nagyobb ütemben bővül, amiből végtelen, egyre gyorsabb és gyorsabb ütemű gazdasági növekedés következik. Ez azt is jelenti, hogy a megtakarítási ráta, amely a Solow-modellben a kibocsátásnak csak a szintjére hatott, de egyensúlyi növekedési ütemére nem, itt a növekedési ütemet is befolyásolja: minél nagyobb a megtakarítások aránya, a gazdaság annál gyorsabb ütemben halmoz fel tőkét, amiből annál gyorsabb gazdasági növekedés következik.

Az $\alpha+\eta=1$ esetben a két egymással ellentétes hatás pontosan kiegyenlíti egymást. Ekkor az aggregált termelési függvény $Y=A \cdot K$ alakra egyszerüsödik (in- 
nen az „AK modell” elnevezés), így a kibocsátás és a tökeállomány növekedési üteme megegyezik egymással:

$$
\dot{Y} / Y=\dot{K} / K=s \cdot A-\delta \text {. }
$$

Az $A=\kappa$ behelyettesítést alkalmazva ez pontosan megegyezik a Harrod-Domarmodell amortizációt explicit módon tartalmazó változatának eredményével ${ }^{39}$, ami nem is meglepő, figyelembe véve, hogy a Harrod-Domar-modell „termelési függvénye" $Y=\kappa \cdot K$ alakú. Utóbbival ellentétben azonban itt nem valamilyen rögzített technológia, a termelési tényezők helyettesíthetetlensége jelenik meg ebben az alakban, hanem az, hogy a hagyományos neoklasszikus termelési függvény csökkenő mérethozadékát ellensúlyozza az a hatás, hogy a tőkefelhalmozás javítja a termelékenységet.

Az endogén növekedési modellek összetettebb változatai elkülönült kutatási tevékenységet tartalmaznak, melynek eredményeként - valamilyen csatornán keresztül - növekszik a termelékenység. Az egyik lehetőség, hogy a neoklasszikus termelési függvényben szereplő $A$ változót egyszerüen úgy kezeljük, mint a rendelkezésre álló tudásállományt, és a kutatási tevékenység eredményeként ez a tudásállomány növekszik. A kutatási szektor termelési függvénye tehát

$$
\dot{A}=B \cdot\left(a_{K} \cdot K\right)^{\beta} \cdot\left(a_{L} \cdot L\right)^{\gamma} \cdot A^{\theta},
$$

ahol $a_{K}$ és $a_{L}$ az adott időszakban rendelkezésre álló tőke és munkaerő azon részarányát jelöli, amelyet a kutatásra fordítanak, $B$ pedig egy olyan paraméter, amely a kutatás sikerességét méri. Így a technológiai fejlődés ütemét az

$$
\dot{A} /_{A}=B \cdot\left(a_{K} \cdot K\right)^{\beta} \cdot\left(a_{L} \cdot L\right)^{\gamma} \cdot A^{\theta-1}
$$

összefüggés adja meg. ${ }^{40}$

Egy másik lehetőség, ha a kutatási tevékenységet úgy építjük be a gazdaságot leíró modellbe, hogy eredményeként újabb és újabb félkész termékek, tőkejavak jelennek meg, amelyek a fogyasztásra szánt termék előállításában hasznosíthatók. (Romer, 1990) Ezzel kapcsolatban felmerülhet problémaként, hogy a termelőeszközök köre folyamatosan bővül, azok nem évülnek el, ezért harmadikként olyan modellek is építhetők, amelyekben a kutatás eredményeként nem a tökejavak egyre több változata jelenik meg, hanem a régebbieket váltják fel újabbak, jobb minőségüek. (Aghion és Howitt, 1992) E modell érdekessége, hogy egyszerre jelennek meg benne

\footnotetext{
${ }^{39}$ Lásd 2.3. alfejezet.

${ }^{40}$ Egy ilyen modell részletes leírását lásd Romer (2001, pp. 99-114).
} 
pozitiv és negativ externális hatások. Egyfelől a (sikeres) kutatási tevékenység a később mások által kifejlesztett eszközök termelékenységét is növeli, másrészt viszont elavulttá teszi a korábbi kutatási eredményeket, így károsítja azok kifejlesztőit, elértékteleníti az azokat védő szabadalmakat. Ezek az externáliák ellentétes irányban térítik el a kutatási aktivitás mértékét a társadalmi optimumtól.

Mindhárom modellváltozat esetén azzal az átváltással szembesül a gazdaság, hogy a későbbi termelési (és fogyasztási) lehetőségeket javító kutatási tevékenység erősítéséhez erőforrásokat kell átcsoportosítani a közvetlenül hasznosságot jelentő jelenlegi fogyasztási javakat előállító termelőszektorból. Ezt az átváltást többféleképpen lehet kezelni. Egyrészt megadhatóak olyan exogén paraméterek, amelyek az erőforrások megoszlását mutatják (mint a fentebbi $a_{K}$ és $a_{L}$ paraméterek), másrészt optimalizáció eredményeként is kialakulhatnak: az innovátorokat az ösztönzi erőforrások kutatásra fordítására, hogy kutatásuk eredményét (legyen az újabb, vagy jobb minőségü félkész termék) eladhatják a végső terméket előállító szektor számára. Nyilván csak akkor létezik ez az ösztönzés, ha pozitív bevételre tudnak szert tenni, vagyis piaci erővel rendelkeznek. ${ }^{41}$ Ha a különböző félkész termékek előállítói monopolhelyzetben vannak, akkor el tudják adni eredményüket a versengő termelőszektor számára olyan áron, amely megegyezik az adott félkész termék határtermékértékével. Ez a bevétel teszi lehetővé, hogy (a kutatás sikerének valószínűségétől, illetve egyéb paraméterektől függő mértékben) különböző termelési tényezőket a kutatásban használjanak fel.

Romer (1986) modelljében is racionális szereplők allokálnak erőforrásokat kutatásra, azonban némileg más logika mentén. Fontos eleme a modellnek, hogy a tudásállomány, vagyis a kutatási tevékenység eredménye nem csak a saját vállalat számára felhasználható, hiszen nincs rivalizálás a tudományos eredmények, innovációk alkalmazásában. Ez úgy jelenik meg, hogy a vállalatok termelési függvényében nem csak a saját felhalmozott tudástőkéjük szerepel az egyéb felhasznált erőforrások mellett, hanem a teljes gazdaság rendelkezésére álló összes tudásállomány is. Vagyis minden egyes kutatási tevékenységnek externális hozama is van, a többi vállalat termelékenységét is növeli. Ha a termelési függvények a saját tudásállomány és egyéb erőforrások tekintetében állandó mérethozadékúak, akkor ez az externális hatás növekvő mérethozadékúvá teszi őket. A növekvő mérethozadékú termelési függvény

${ }^{41}$ Mivel a tudás, kutatási eredmények alkalmazása, „fogyasztása” nem rivalizáló, ezért az újabb és újabb felhasználás határköltsége nulla. Így versenyzői piacon az ára is nulla lenne. 
pedig exogén népességnövekedés vagy technológiai fejlődés nélkül is tartós, egyre nagyobb ütemü gazdasági növekedést eredményez. Ez ráadásul azért is fontos, mert így azok a paraméterek, amelyek meghatározzák, hogy az erőforrások mekkora részét fordítják kutatásra, a növekedési ütemre is hatással vannak, nem csak a fejlettségi szintre. Csökkenő mérethozadékú termelési függvény esetén ugyanis ez lenne a helyzet - csakúgy, mint ahogy a Solow-modellben is csak a jövedelmi szintre hat a megtakarítási ráta, az egyensúlyi növekedési ütemre nem.

A technológiai fejlődést endogenizáló (és így a modell keretein belül kialakuló ütemü, tartós növekedést produkáló) modellek a neoklasszikus modellcsalád egy fontos problémáját orvosolják, hiszen azokkal kapcsolatban a legfontosabb kritika éppen az volt, hogy az egyensúlyi növekedési pályán az a technológiai fejlődés vezérli a gazdaság bővülését, amelyről a modellek nem tesznek érdemi megállapítást. Ilyen értelemben azt mondhatjuk, hogy ezek a modellek a világméretü növekedést képesek magyarázni, hiszen a technológiai fejlődés (illetve az azt meghatározó tényezők) szerepe valóban megkérdőjelezhetetlen a tartós gazdasági növekedés, valamint annak gyorsulása-lassulása tekintetében. Emellett az is lényeges pont, hogy a világgazdaságban akkor indult be a mindmáig megfigyelhető, tendenciózus növekedés, amikor mintegy kétszáz éve az ipari forradalom robbanásszerü technológiai fejlödést indított el. ${ }^{42}$

Azt is látni kell azonban, hogy az egyes országok közötti fejlettségbeli eltéréseket e modellek sem tudják kielégítően megmagyarázni. Ha a tőkeellátottságban megfigyelhető eltérések mellett a technológiai színvonal különbségeivel szeretnénk magyarázni a valóságban tapasztalható jövedelmi különbségeket, akkor évszázados technológiai lemaradásokat kell feltételeznünk ehhez például a fekete-afrikai országok és az Egyesült Államok között. Egész egyszerüen nincs „elég nagy” technológiai szakadék az egyes országok között ahhoz, hogy ez magyarázni tudja az óriási fejlettségbeli eltéréseket. Ráadásul nem is igen alakulhat ki ilyen mértékü különbség, mert a technológia „fogyasztása” nem rivalizáló, a kizárhatóság is korlátozott (a szabadalmi védelem véges időre szól), vagyis a jelenlegi globális gazdasági kapcsolatok mellett nem lehet megakadályozni, hogy a kutatási eredmények (akár késéssel, de) elterjedjenek a világban.

\footnotetext{
${ }^{42}$ Másképpen: amikor a felgyorsuló technológiai fejlődés révén a gazdaság ki tudott szabadulni a 2.2. alfejezetben bemutatott malthusi csapdából.
} 
Mindez alapján azt mondhatjuk, hogy nem elsősorban a technológia számít, hanem annak alkalmazási képessége. Ez pedig tulajdonképpen nem más, mint az adott gazdasági egység rendelkezésére álló humán tőke állománya. ${ }^{43} \mathrm{~A}$ humán tőke közgazdasági szempontból nagyon is különbözik a technológiától, tudástól. Ugyanis az utóbbi esetében versengésről nincs szó, bizonyos esetekben kizárhatóságról sincs, vagyis többé-kevésbé közjószágnak tekinthető. Ezzel szemben a humán tőke egyértelműen a magánjavak jellemzőivel bír.

\subsection{A humán tőke szerepe a gazdasági növekedésben}

Humán tőke alatt az embereknek a képzetlen kétkezi munka feletti jövedelemtermelő képességeinek, tudásának állományát értjük. Ez ugyanúgy egyfajta beruházás eredményeként halmozható fel, mint a fizikai tőke, hiszen az oktatásban vagy akár munkahelyi képzésben való részvétel erőforrások feláldozásával jár - későbbi várt hozamok reményében. A fogalom már a korai közgazdászoknál (Petty, Smith, von Thünen) megjelent, a huszadik század közepén több nagy hatású szerző (Mincer, 1958, Schultz, 1963, 1971, Becker, 1964) is foglalkozott az emberi töke elméletének (föleg mikroökonómiai szempontú) vizsgálatával.

A legegyszerübb módszer a humán tőke növekedési modellbe való beillesztésére Mankiw, Romer és Weil (1992) nevéhez füződik. Ök egyszerüen a Solowmodellt egészítették ki ezzel az újabb változóval úgy, hogy a fizikai és a humán tőke alakulása egymással teljesen analóg. Modelljük termelési függvénye így

$$
Y=F(K ; H ; A \cdot L)
$$

alakú, ahol $H$ jelöli a termelésben felhasznált emberi tőke állományát (az egy hatékonysági egységre jutó értékét pedig a továbbiakban $h) .{ }^{44}$ A szokásoknak megfelelően állandó mérethozadékot és munkakiterjesztő technológiai fejlődést feltételeznek. A fizikaitőke-beruházásokhoz hasonlóan az emberi tőke felhalmozására szánt jövedelemhányad is konstans $\left(s_{h}\right)$, így időbeli alakulását a

$$
\dot{H}=s_{h} \cdot Y-\delta \cdot H
$$

\footnotetext{
43 „Belgium például nem azért gazdag, mert sok új technológiát fejlesztettek ott ki, hanem azért, mert megvan az a humán tőkéje és azok a társadalmi intézményei, amelyek lehetővé teszik, hogy alkalmazni tudjon máshol kifejlesztett technológiákat.” (Kremer, 1993, p. 686)

${ }^{44}$ Romer (2001) könyvében másképp jelenik meg a humán tőke a Solow-modellben: a termelési függvény az állandó mérethozadékú $Y=F(K ; A \cdot H)$, ahol $H=L \cdot \phi(E), E$ pedig az átlagos munkavállaló iskolázottságát jelöli.
} 
egyenlet írja le (teljes mértékben a $\dot{K}=s_{k} \cdot Y-\delta \cdot K$ egyenletnek megfelelő módon, ahol $s_{k}$ a fizikai tőke felhalmozására fordított jövedelemhányad). Jól láthatóan azzal a némileg önkényes egyszerüsítő feltétellel is éltek, hogy a fizikai és emberi tőke ugyanabban a $\delta$ ütemben amortizálódik. Az egy hatékonysági egységre jutó mennyiségekben kifejezve a felhalmozási egyenletek a

$$
\dot{h}=s_{h} \cdot y-(n+g+\delta) \cdot h,
$$

illetve

$$
\dot{k}=s_{k} \cdot y-(n+g+\delta) \cdot k
$$

formát öltik, amiből az egyensúlyi növekedési pályán a $h /{ }_{k}=s_{h} / s_{k}$ állandó tőkearány adódik.

Állandó mérethozadékú Cobb-Douglas technológia esetén az aggregált termelési függvény extenzív formája

$$
Y=K^{\alpha} \cdot H^{\beta} \cdot(A \cdot L)^{1-\alpha-\beta},
$$

intenzív formája

$$
y=k^{\alpha} \cdot h^{\beta}
$$

A két egyensúlyi feltétel

$$
s_{k} \cdot\left(k^{*}\right)^{\alpha} \cdot\left(h^{*}\right)^{\beta}=(n+g+\delta) \cdot k^{*},
$$

illetve

$$
s_{h} \cdot\left(k^{*}\right)^{\alpha} \cdot\left(h^{*}\right)^{\beta}=(n+g+\delta) \cdot h^{*},
$$

amelyekböl

$$
k^{*}=\left(s_{k}^{1-\beta} \cdot s_{h}^{\beta} /(n+g+\delta)\right)^{\frac{1}{1-\alpha-\beta}} \text { és } h^{*}=\left(s_{k}^{\alpha} \cdot s_{h}^{1-\alpha} /(n+g+\delta)\right)^{\frac{1}{1-\alpha-\beta}} .
$$

Mindezt visszahelyettesítve a termelési függvénybe azt kapjuk az egy hatékonysági egységre jutó jövedelem egyensúlyi értékére, hogy

$$
y^{*}=\left(s_{k}^{\alpha} \cdot s_{h}^{\beta} /(n+g+\delta)^{\alpha+\beta}\right)^{\frac{1}{1-\alpha-\beta}} \cdot \text { (i.m., pp. 416-417) }
$$

Ez pedig (logaritmizált formában) ökonometriai módszerekkel tesztelhető. A keresztmetszeti adatok vizsgálatával a szerzők azt kapták eredményül, hogy a Solowmodell magyarázó erejét érdemben növeli a humán töke bevonása a modellbe. Ráadásul 75, illetve 98 országot tartalmazó nagyobb mintáik esetében a becslés eredményeként kapott $\alpha$ és $\beta$ paramétereik nagyon közel vannak egyharmadhoz, amit a jövedelemarányok alapján szokás feltételezni. (i.m., p. 421) 
Az emberitőke-beruházás bevonása egy növekedési modellbe azonban korábban, először Uzawa (1965) tanulmányában jelenik meg, még ha a szerző nem is használja ezt a kifejezést. A neoklasszikus modellkeretet annyival egészítette ki, hogy a munka termelékenységének növekedését egy „oktatási szektornak” nevezett ágazat eredményének tekinti. ${ }^{45}$ Az oktatási szektor termelési függvényében egyedül a munkaerő jelenik meg termelési tényezőként:

$$
\dot{A} /_{A}=\phi\left(L_{E} / L\right)
$$

ahol $L_{E}$ a teljes munkaerőnek e szektor által alkalmazott része. A termelőszektor termelési függvénye így

$$
Y=F\left(K ; A \cdot L_{P}\right),
$$

ahol $L_{P}$ a termelésben foglalkoztatott munkaerö,

$$
L=L_{P}+L_{E}
$$

A modellnek adható tehát olyan értelmezés, hogy a termelésből kivont (oktatásban részt vevő) munkaerö-állomány nagyságán múlik, hogy milyen ütemben növekszik a munka termelékenysége, vagyis a humán tőke felhalmozása vezet a hatékonyság javulásához. (i.m., p. 19) Belátható, hogy létezik egyensúlyi növekedési pálya, amelyen úgy alakul a beruházási arány, illetve az oktatásban részt vevő munkaerő aránya, hogy maximális legyen a társadalom jóléte, amelyet a szerző az egy főre jutó fogyasztás diszkontált összegeként azonosít.

Hozzá kell tenni, hogy természetesen másképpen is értelmezhető a modell: az oktatás helyett beszélhetünk kutatószektorról, ez esetben az előző alfejezetben tárgyalt endogén növekedési modellek egy egyszerüsített változatát (a kutatásban tőkét nem használnak, csak munkaerőt) kapjuk meg.

Lucas (1988) tulajdonképpen ezt a modellt fejlesztette tovább és különítette el a humán töke és a technológiai színvonal változóit. Modelljében $N$ munkavállaló van, akik mindegyike rendelkezik valamekkora $h$ egyéni emberitőke-állománnyal, vagyis

$$
N=\int_{0}^{\infty} N(h) d h .
$$

\footnotetext{
${ }^{45}$ Az idézőjeleket az indokolja, hogy a szerző is kifejti, valójában nem csak a szük értelembe vett oktatás tartozik ebbe az ágazatba, hanem minden olyan tevékenység, ami javítja a munka termelékenységét (például az egészségügy vagy közberuházások is). (Uzawa, 1965, pp. 18-19)
} 
Az adott humán tőkével rendelkező egyének munkaidejük $l(h)$ hányadát a termelésben való részvételre, $(1-l(h))$ hányadát pedig önmaguk képzésére fordítják. Így a termelésben hasznosítható összes, képzettséggel kiigazított munka mennyisége

$$
L=\int_{0}^{\infty}(l(h) \cdot N(h) \cdot h) d h .
$$

Az aggregált termelési függvény Cobb-Douglas-technológiát ír le:

$$
Y=A \cdot K^{\alpha} \cdot L^{1-\alpha} \cdot h_{a}^{\beta},
$$

ahol

$$
h_{a}=\int_{0}^{\infty}(h \cdot N(h)) d h /_{N}
$$

az emberek átlagos humántőke-állománya. (i.m., pp. 17-18) Enélkül a termelési függvény állandó mérethozadékú lenne, azonban a humán tőke externális hatásai növekvő mérethozadékúvá teszik azt. Növekvő mérethozadék esetén pedig - mint korábban is volt róla szó - a paraméterek (például a reprezentatív fogyasztó diszkontrátája) a tartós növekedés ütemére is hatással vannak.

Ha az egyszerüség kedvéért azt feltételezzük, hogy a munkavállalók egyformák, vagyis mindegyikük ugyanakkora humán tőkével rendelkezik, akkor időmegosztásuk is azonos lesz $(l(h)=l$ mindenkire), így

$$
L=l \cdot N \cdot h,
$$

vagyis a termelési függvény

$$
Y=A \cdot K^{\alpha} \cdot(l \cdot N \cdot h)^{1-\alpha} \cdot h_{a}^{\beta} .
$$

Ebben az esetben természetesen $h_{a}=h$, de mégis külön kell jelölni, hiszen az egyéni, reprezentatív döntéshozó számára az átlagos humántőke-állomány továbbra is külső adottság. A humán tőke felhalmozási egyenlete

$$
\dot{h} / h=\phi(1-l),
$$

ami jól láthatóan az Uzawa-modellnek felel meg, hiszen az ott szereplő jelölésekkel

$$
1-l={ }^{L_{E}} /{ }_{L} \text {. (i.m., pp. 18-19) }
$$

A pozitív externáliák bevonása révén a modell szoros rokonságban áll Romer (1986) modelljével. A különbség az, hogy míg ott a közös tudásállomány, addig itt az átlagos humántőke-állomány hat az egyes vállalatok termelékenységére. De a lényeg ugyanúgy a pozitív externália, ami miatt egyfelől növekvő mérethozadékúvá válik a termelési függvény, másfelől pedig a rendszer nem a társadalmi optimumban kerül egyensúlyba. Ha az emberi tőke felhalmozásának pozitív externális hatásai vannak, akkor - mivel ezek a hatások nincsenek a piacon kompenzálva - a társadal- 
milag optimálisnál kevesebb erőforrást fordítanak e felhalmozásra a szereplők. Ugyanez a helyzet akkor is, ha nem humántőke-beruházásról, hanem a Romermodellhez kapcsolódóan kutatás-fejlesztésről beszélünk.

Az átlagos humán tőke termelési függvényben való megjelenésének még egy fontos következménye van. Így ugyanis az adott munkavállaló humán tőkéjének termelékenysége nagyobb abban az országban, ahol magasabb az átlagos állomány, emiatt a megtérülése, vagyis a munkavállaló jövedelme is nagyobb lesz. Ez képes magyarázni a brain-drain jelenségét, vagyis azt, hogy a humán tőke inkább áramlik a szegényebb országokból a gazdagabbak felé, mint fordítva. Csökkenő mérethozadékú termelési függvény esetén a kiegyenlítődés irányába ható erőket kéne megfigyelnünk, vagyis azt, hogy a termelési tényezők a velük jobban ellátott országból áramolnak a kevésbé ellátott országba. A humán tőke esetében egyértelmüen nem ez a helyzet.

Érdemes megemlíteni, hogy ebbe az eszmekörbe illeszkedik Jánossy (1966) elmélete is: a háborúk és egyéb gazdasági megrázkódtatások utáni „növekedési csodák" tulajdonképpen helyreállítási periódusoknak tekinthetők, amelyek addig tartanak, amíg a gazdaság teljesítménye vissza nem tér a visszaesés előtti trendvonalára, vagyis el nem éri azt a szintet, ahol tartana a megrázkódtatás nélkül. Ennek a trendvonalnak a meredekségét, vagyis a hosszú távú növekedési ütemet az emberi erőforrások határozzák meg.

\subsection{A növekedés fundamentális okai ${ }^{46}$}

Az előzőekben ismertetett növekedéselméleti modellek fontos összefüggésekre hívják fel a figyelmet. A tartós gazdasági növekedéshez szükség van a fizikai és humán tőke felhalmozására, illetve a technológiai színvonal javítására, vagyis ipari, infrastrukturális, oktatási beruházásokra, kutatás-fejlesztésre. Azonban önmagukban ezek nem tekinthetők a gazdasági növekedés okainak, hiszen ha „ennyire egyszerü” lenne a képlet, akkor mindenhol azt kéne látnunk, hogy az erőforrásokat ebbe az irányba összpontosítják, és ennek köszönhetően mindenhol tartós növekedési pályán mozognak a gazdaságok. A valóságban viszont nem ez a helyzet, országok sora szenved folyamatos stagnálástól, vagy akár kifejezetten gazdasági visszaeséstől hosszú időszakon keresztül.

${ }^{46}$ Ez az alfejezet alapvetően Acemoglu, Johnson és Robinson (2005) gondolatmenetére épül, azt egészíti ki más forrásokkal és saját gondolatokkal. 
Fontos összefüggés, hogy az az ország, amelyik több fizikai és emberi tőkét halmoz fel, magasabb jólét elérésére képes, de legalább ilyen fontos az a kérdés, hogy miért tud egyik ország több fizikai és emberi tőkét felhalmozni, mint a másik. Vagyis lényeges a gazdasági növekedés fundamentális okainak vizsgálata. (Acemoglu, Johnson és Robinson, 2005) Ugyanezt a konvergencia kérdéskörére is vonatkoztathatjuk. Ahogy korábban is említettük már, empirikus kutatások sokszor kimutatják a feltételes konvergencia jelenségét, vagyis azt, hogyha két ország hasonló paraméterekkel (például megtakarítási rátával) írható le, akkor a kezdetben szegényebb ország gyorsabb növekedést fog produkálni. Azonban gazdaságpolitikai szempontból ez korlátozottan releváns, a fontos kérdés valójában az abszolút konvergencia hiánya: miért nem ugyanakkora a megtakarítási ráta (illetve egyéb paraméterek) a különböző országokban, hogyan lehet ennek alakításával a megfigyelhető jövedelmi különbségeket csökkenteni.

Több tényező is felmerül mint az országok közötti fejlettségi és növekedési különbségek lehetséges fundamentális oka. Az egyik ilyen a tágabb értelemben vett földrajzi környezet. Ebbe számos részlet beletartozik, amelyeket itt csak címszavakban említek. Az éghajlati és talajviszonyok jelentősen befolyásolják a mezőgazdaság termelékenységét. A domborzat, vízrajz a közlekedés és kereskedelem lehetőségére van hatással. A természeti erőforrásokkal való ellátottságnak az iparra és a kereskedelemre is nagy befolyása van. Az éghajlatnak egészségügyi következményei is vannak: a különböző betegségek általában jelentősen kötődnek az éghajlati viszonyokhoz, a munkaerő egészségi állapota pedig nagyban meghatározza a termelékenységét. Végül az éghajlatnak lehetnek hatásai a fogyasztói preferenciákra, munkamorálra stb. is.

A fentebb említett tényezők mindegyikével kapcsolatban igaz, hogy befolyásolják a növekedési lehetőségeket, azonban hatásuk minden bizonnyal korlátozott. A földrajzi környezet valóban okozhat érdemi eltéréseket a mezőgazdaság termelékenységében, azonban a fejlett országok nemzeti össztermékében általában 2-3 százalékos súlya van az agrárszektornak, ennek hatékonysága nem magyarázhatja a megfigyelhető hatalmas jövedelmi különbségeket. Noha megfelelően kiaknázva a természeti erőforrások minden bizonnyal hozzájárulnak a gazdasági növekedéshez, számos olyan országot találunk, amely annak ellenére szerepel a leggazdagabbak 
sorában, hogy energiahordozókban, egyéb természeti erőforrásokban szegény. ${ }^{47}$ Sőt, legalább ilyen fontos lehet az ún. erőforrás-átok (,holland kór”): az erőteljes nyersanyagkivitelből származó deviza-beáramlás hatására felértékelődik a hazai valuta, ami rontja a többi szektor versenyképességét. Ráadásul a gazdasági szerkezet is eltorzulhat, túlságosan erős, a nyersanyag-kitermelő szektortól való függés alakulhat ki, így a nyersanyag világpiaci árának volatilitása erős gazdasági ingadozásokhoz vezethet. Ami az egészségügyi állapotot illeti, szintén hiba volna erre visszavezetni a gazdasági különbségeket, hiszen az elmúlt száz évet megelőzően Európában is nagyon komoly járványok pusztítottak, és az ipari forradalom idején, vagyis a gyors gazdasági növekedés megindulásakor az európai egészségügyi állapotok is igen roszszak voltak.

Egy másik lehetséges magyarázó tényező a kultúra. Eszerint az Egyesült Államok, Kanada vagy Ausztrália azért lényegesen fejlettebbek a latin-amerikai országoknál, mert a korábbi gyarmatosítók más-más kultúrát hoztak magukkal, és az angolszász kultúra a gazdasági fejlődés szempontjából előnyösebb, mint az ibériai (nagyobb szerepe van a gazdasági teljesítménynek, takarékosságnak stb.). Egy másik lehetséges példa a kelet-ázsiai kultúra szerepe Japán vagy a „kis tigrisek” felemelkedésében. Természetesen a kulturális, vallási elemeknek lehet szerepe a gazdasági teljesítményben ${ }^{48}$, de önmagukban ezek sem bírnak elegendő magyarázó erővel. A karibi térség volt brit gyarmatai között ugyanúgy találni relatíve gazdagabbakat (Trinidad és Tobago, Bahama-szigetek) és szegényebbeket (Jamaica, Belize), mint a volt spanyol gyarmatok körében, illetve a világ más részein is van számos nagyon szegény korábbi brit gyarmat (Uganda, Kenya vagy Banglades). Az ázsiai országokat illetően pedig nem mondhatjuk azt, hogy például a japán kultúra jelentős mértékben megváltozott volna akár az 1960-as, akár az 1990-es években - a robbanásszerü növekedés éveiben, illetve az ún. ,elvesztett évtizedben”.

Általában is elmondhatjuk a földrajzi, illetve kulturális elemek szerepét hangsúlyozó elméletek kritikájaként, hogy nem képesek magyarázni a kelet-ázsiaihoz hasonló „gazdasági csodákat”, illetve egyes országok leszakadását, hiszen a földrajzi

\footnotetext{
${ }^{47}$ Természetesen az is igaz, hogy nehéz olyan országot találni, amelynek földrajzi környezete minden szempontból előnytelen volna, se jó minőségü termőföld, se a föld mélyén megbúvó ásványkincsek, se jó közlekedési, halászati lehetőségek, vagy akár turisztikai vonzerőt biztosító természeti csodák ne állnának rendelkezésre. Ausztria és Svájc esetében például az elérhető vízi energia vagy a turizmus fontos tényezö, azonban véleményem szerint nem tekinthetjük ezeket fejlettségük fö magyarázóinak. Hasonló a helyzet Finnországgal kapcsolatban is.

${ }^{48}$ A vallásosság és gazdasági növekedés, gazdasági fejlettség kapcsolatáról érdekes tanulmányt írt Barro és McCleary (2003).
} 
körülmények vagy kulturális viszonyok messze nem változnak olyan hirtelenséggel és olyan mértékben, mint ami indokolni tudná e jelenségeket. ${ }^{49}$

Ugyanígy nem képesek magyarázattal szolgálni ezek az elméletek a megosztott országok tapasztalataira. A második világháború után Észak- és Dél-Korea közel azonos fejlettségi szinten állt, a történelmi hagyományokban, kultúrában nem volt különbség, ugyanígy a földrajzi környezet elemeiben sem. Az elmúlt hetvenöt évben azonban eltérő politikai és gazdasági rendszerben müködtek, aminek eredményeként egészen eltérő növekedési pályára álltak. Dél-Korea a „kis tigrisek” egyikeként gyors fejlődésen ment keresztül az elmúlt évtizedekben, míg Észak-Korea a világ egyik legszegényebb országává vált. Vásárlóerő-paritáson számolva az egy főre jutó GDPben mintegy húszszoros a különbség a két ország között. (CIA, 2016) Hasonló minta rajzolódott ki Kelet- és Nyugat-Németország viszonyában is. Gyakorlatilag azonos kiinduló helyzetből, azonos kulturális és társadalmi örökséggel indulva a megosztottság négy évtizede alatt hatalmas jóléti szakadék alakult ki az ország két fele között. Az újraegyesítés után huszonöt évvel az országon belül nyugatról keletre áramló transzferek eurómilliárdjai ellenére még mindig a volt NDK tartományai az ország legszegényebbjei. ${ }^{50}$

Mindezek alapján azt mondhatjuk, hogy a gazdasági növekedés és fejlettség különbségeinek legfőbb oka az egyes országokban kialakult intézményekben keresendő. Ezalatt azokat az emberek által alkotott (tartós, de változtatható) játékszabályokat értjük, amelyek az egyéni ösztönzőket, illetve a társadalmi-gazdasági interakciókat befolyásolják. A gazdasági fejlődés szempontjából legfontosabb ilyen intéz-

\footnotetext{
${ }^{49}$ A földrajzi tényezőkkel kapcsolatban hozzá kell tenni, hogy bár maguk csak lassan változnak, gazdasági értékükben lehetnek jelentős elmozdulások. Elég csak arra gondolni, hogy a technológiai fejlödés hatására felértékelődhet vagy éppen elértéktelenedhet egy-egy természeti erőforrás. Ugyanígy például Amerika felfedezésével és a fö kereskedelmi útvonalak fokozatos eltolódásával megváltozott az európai országok kontinensen belüli elhelyezkedésének ,relatív értéke”. Az ezekhez hasonló jelentőségủ változások azonban viszonylag ritkák. Az ilyen esetekben a változásokhoz való alkalmazkodás képességének szerepe központi jelentőségü.

${ }^{50}$ A szocialista örökségnek ráadásul a gazdasági lemaradáson túlmutató hatásai is vannak a preferenciákra: a keleti országrész lakói nagyobb mértékben támogatják az állam újraelosztó szerepét, kisebb jelentőséget tulajdonítanak az öngondoskodásnak. (Alesina és Fuchs-Schundeln, 2005) E probléma egy másik vetületére hívta fel a figyelmet Kornai (1989) is: „Az állammal kitolni, az állam vagyonát eltulajdonítani, az állammal szembeni kötelezettség alól kibújni - valljuk meg -, az emberek szemében nem szégyen, sőt egy kissé dicsőség is. Baleknak tartják, aki nem ezt teszi. Mindenkor elismerést keltett a kiskamaszok körében, ha bliccelni tudtak a köztulajdonban lévő villamoson. Az elmúlt évtizedekben ez a bliccelés vált a tipikus állampolgári magatartássá. Irreális arra számítani, hogy bármilyen politikai fordulat következzék is be, és még ha olyan államkassza jön is létre, amely felett valóban a nép választott képviselői rendelkeznek, ez a magatartás tömegesen, egyik napról a másikra megváltozik. Senki sem tudná megjósolni, hogy a közszellem fejlődése mennyi időt fog igénybe venni." (pp. 63-64)
} 
mények a magántulajdont védő, a piaci koordinációt és a szerződéses viszonyokat elősegítő formális és informális szabályok. A szocialista és kapitalista rendszer között például fontos intézményi különbség, hogy egy-egy sikeres gazdasági innovációnak a piacgazdasági keretek között hatalmas az egyéni megtérülése, míg a hierarchizált és bürokratikus szocialista gazdaságban ez jelentős mértékben blokkolva van, így értelemszerüen sokkal kisebb a vállalkozó- és kezdeményezőkészség, ami pedig szükséges volna a technológiai fejlödéshez és a gazdasági növekedéshez. (Kornai, 2011) Ugyanígy a magántulajdon biztonságával kapcsolatos kételyek (például az állami kisajátítás veszélye) visszaveti a befektetési hajlandóságot, vagyis lassabb tőkefelhalmozáshoz vezet.

A jogszabályokban, kormányzati működésben megnyilvánuló formális intézmények mellett fontos hangsúlyozni az informális intézmények jelentőségét. Ezek olyan társadalmi normák, viselkedési szabályok, amelyek alapvetően meghatározzák az emberek életét és azon keresztül a gazdaság teljesítményét is, anélkül, hogy jogi formát öltenének.

Az észak-amerikai országok tehát nem azért fejlettebbek a kontinens déli részénél, mert az angolszász kultúra ,,jobb”, mint az ibériai, hanem azért, mert ezekben az országokban olyan jog- és intézményrendszer alakult ki, ami jobban védi a magántulajdont és inkább támogatja a piaci mechanizmust. Acemoglu, Johnson és Robinson (2005) szerint ez annak köszönhető, hogy az északi gyarmatok könnyen kiaknázható természeti kincsekben szegényebbek voltak karibi és dél-amerikai társaikhoz képest, illetve alacsonyabb volt az öslakos népsürüség is, így a gyarmatosítók nem „lerabolni” akarták e területeket, hanem „felfejleszteni”. Emiatt alakítottak ki olyan intézményrendszert, ami a többség (az északi gyarmatok esetében ez magukat a telepeseket jelenti) tulajdonjogait védi. A közép- és dél-amerikai térségben ezzel szemben az őslakosok voltak többségben, így olyan intézményrendszert formáltak a gyarmatosítók, ami az európai elit érdekeit szolgálta a többséggel szemben.

Az, hogy az intézményi környezet hat a gazdasági fejlődésre, a legkevésbé sem nevezhető új felfedezésnek. Henry George (1914 [1879]) például a következőket írta: „Ahol a kormányzat zsarolások láncolata és a tőke némi biztonságát mandarinoktól kell megvásárolni, ahol a szárazföldi szállítás emberek vállain nyugszik, ahol a hajó szerkezetének olyannak kell lennie, hogy tengerihajóul ne szolgálhasson, ahol a kalózság rendes foglalkozás és a rablók gyakran seregesen járnak, ott szegénységnek kell uralkodnia és a rossz termésből éhínségnek kell következnie, bármily ritka is 
legyen a népesség.” (i.m., p. 128) Illetve más helyen: „[...] minden oly veszély, hogy emberi lények oly világba születnek, hol róluk gondoskodni nem lehet, nem a természet rendelkezéséböl következik, hanem a társadalom rossz elrendezéséböl, mely az embereket a gazdagság közepette nyomorogni kényszeríti.” (i.m., p. 145)

Más elméletekhez hasonlóan ez is jelentős fejlődésen, formalizálódáson és átalakuláson ment keresztül az évtizedek folyamán. E tekintetben elvitathatatlan jelentőségü a huszadik század második felében Douglass North, az elmúlt években pedig Daron Acemoglu munkássága. Az intézmények szerepe megkerülhetetlen, még ha a számszerüsített elemzés nem is egyszerü ebben az esetben. Aron (2000) széleskörü áttekintést ad az addig megjelent irodalomról, és felhívja a figyelmet a felmerülő problémákra. Egyrészt vannak a méréssel kapcsolatos nehézségek: az intézmények minősége sok esetben közvetlenül nem számszerüsíthető, hanem részben szubjektív elemeket is tartalmazó módon értékelhető (például üzleti kockázatokat becslő indexek). Bizonyos szempontok esetében nem is feltétlenül számértékek, hanem inkább csak rangsorok állnak rendelkezésre, amelyek korlátozottabban használhatók ökonometriai vizsgálatok során. Másrészt fontos probléma lehet az endogenitás: az intézmények hatnak a gazdasági teljesítményre, de visszafelé is van összefüggés, a gazdasági teljesítmény befolyásolja az intézmények működését, minőségét. Mindezekkel együtt is azt találja a szerző, hogy kimutatható pozitív kapcsolat az intézményi minőség és a gazdasági növekedés között, de ez a kapcsolat az említett problémák miatt nem mindig robosztus.

Két további megjegyzést kell füzni a fundamentális okokkal kapcsolatban elmondottakhoz. Az, hogy az intézmények szerepét hangsúlyozzuk, nem jelenti azt, hogy a tág értelemben vett földrajzi-környezeti feltételek, illetve a kultúra ne számítana. Mindkettőnek, de föleg a kultúrának nagyon fontos szerepe lehet abban, hogy az egyes intézményi megoldások hogyan, milyen sikeresen müködnek a különböző országokban, vagy másik oldalról: melyik intézmények tekinthetők a legjobbnak az adott környezetben. A kelet-ázsiai gazdaságok sikertörténete érdekes ebből a szempontból. Több országban (Szingapúr, Dél-Korea) is a nyugati típusú demokráciától eltérő politikai berendezkedés keretei között zajlott le a gazdasági felemelkedés. Ez azonban nem jelenti azt, hogy az ott sikeres intézményi megoldások jelentenék a mindenhol követendő utat. Ez fordítva is igaz: könnyen lehet, hogy ezekben az országokban nem valósult volna meg ilyen mértékü gazdasági növekedés liberálisabb demokrácia esetén. 
A másik fontos megjegyzés az, hogy az intézmények az adott közösség döntéseinek eredményei, vagyis megváltoztathatók. Szerepük hangsúlyozása tehát azt is jelenti, hogy nincs olyan exogén (végső) ok, amelyre az egyes országok növekedési teljesítménye egyértelmüen visszavezethető lenne, és ami eleve determinálná, hogy melyik gazdaság milyen teljesítményre képes. Az adottságok jelenthetnek korlátokat, de azt az intézményrendszer határozza meg, hogy e - sok esetben viszonylag tág korlátok között milyen teljesítményt ér el a gazdaság. Megfelelő (és újra hangsúlyozom: az adott kultúrának, társadalomnak megfelelö) intézményi berendezkedés kialakítása esetén megteremthetők az ösztönzők a megtakarításra, a fizikai és humán tőke felhalmozására, a kutatás-fejlesztésre, és ezeken keresztül a társadalom egészének jólétét szolgáló gazdasági fejlődésre. Természetesen az intézmények megváltoztatása egyáltalán nem egyszerű, hiszen a nagyobb társadalmi jólétet eredményező intézményrendszer kialakítása sem Pareto-javítás: minden status quo-nak vannak haszonélvezői, akik értelemszerüen megpróbálnak ellenállni a változásoknak. Tipikus példa erre a totalitárius vagy autoriter rendszerek hatalmi elitje.

Az elmúlt évtizedekben számos olyan tanulmány született, ami egyes intézményi tényezők gazdasági növekedésben játszott szerepét vizsgálta. A nemzetközi kereskedelmi nyitottság (Rivera-Batiz és Romer, 1991, Berg és Krueger, 2003) elsősorban az erőforrások hatékonyabb elosztását teszi lehetővé (a specializáció és a mérethatékonyság kihasználása által), valamint ösztönzi az innovációt (részben a nagyobb verseny, részben az ötletek, technikai vívmányok áramlása révén). A pénzügyi rendszer (Epaulard és Pommeret, 2005, Levine, 2005) többek között a megtakarítások és beruházási lehetőségek egymásra találását segíti elő, valamint a kockázatok megosztásához, kezeléséhez, illetve a vállalatirányítás javulásához járulhat hozzá. Emellett az egyes vállalatokról, beruházási lehetőségekről szóló információk előállításában is részt vesznek a pénzügyi közvetítők, így a tőke hatékonyabb allokációját segítik elő.

A közpénzügyek és gazdasági növekedés közötti kapcsolatot vizsgáló irodalomra az 5.2. alfejezetben visszatérünk.

\subsection{Tanulságok Kelet-Közép-Európa számára}

A növekedéselméleti irányzatok, modellek fejlődéstörténetének bemutatása után röviden kitérek arra, hogy mi e modellek fő mondanivalója a kelet-közép-európai országok szempontjából. 
A korai növekedési makromodellek (akár a Harrod-Domar-modell, akár a Solow-modell) elsősorban a fizikai tőke jelentőségét hangsúlyozzák. A későbbiekben (3.5. és 4.5. alfejezetek) látni fogjuk, hogy térségünk országainak elmúlt 25 évében kulcsfontosságú volt a - jelentős részben külső forrásból finanszírozott - tőkefelhalmozás. Az állandó tőkekoefficienst feltételező Harrod-Domar-modell alapján a gyors tőkefelhalmozásból tartósan magas növekedési ütem következik, míg a Solowmodell megközelítésében inkább az egyensúlyi növekedési pálya felé való konvergenciáról beszélhetünk, mely során a tőkeellátottság folyamatos növekedése révén fokozatosan mérséklődik a gazdaság bővülési üteme. Az elmúlt években lelassult gazdasági növekedés az utóbbit látszik alátámasztani, azonban a kép ennél lényegesen összetettebb. (4.6. alfejezet)

Ráadásul mindkét modellre igaz, hogy eredendően nagy, zárt gazdaságokra vonatkoznak, így a tőkefelhalmozás forrását bennük az adott ország saját megtakarításai jelentik. A kelet-közép-európai országokra ez nem igaz, a külső források bevonása alapvető jelentőségü e kis, nyitott gazdaságokban. Így a tőkeállomány bővülésére, és azon keresztül a kibocsátás növekedésére külső tényezők is hatnak: például nem csak azért eshet vissza a beruházási aktivitás, mert a tőkeellátottság bővülése miatt csökken a megtérülési ráta az adott gazdaságban, hanem azért is, mert a globális gazdasági bizonytalanságok megnövekedése miatt világszinten mérséklődik a befektetési hajlandóság.

A növekedéselméletek következőként áttekintett irányzata a technológiai fejlődés endogén magyarázatára összpontosított. Noha a fejlett országok és a világgazdaság egésze szempontjából ez egy igen fontos kérdés, véleményem szerint térségünk országai szempontjából ez a modellcsalád kevésbé releváns. Itt ugyanis ezen a téren nem a technológiai színvonal fejlesztése (a „technológiai határ” kitolása) az elsődleges feladat, hanem a fejlettebb országok technológiai színvonalához való felzárkózás.

Ha nem is feltétlenül kutatás-fejlesztésen keresztül, de általánosabb értelemben a termelékenység javítása természetesen nagyon lényeges a kelet-közép-európai gazdaságokban. Ebben a tekintetben pedig a humán tőke és az intézményrendszer szerepe a kulcsfontosságú. Jó minőségű emberi erőforrásokra (jól képzett munkaerőre) és a befektetéseket ösztönző, stabil gazdaságpolitikai és jogi környezetre van szükség ahhoz, hogy adaptálni tudjuk a fejlettebb országok technológiai eredményeit. Ennek a problémakörnek az oktatás és jogrend mellett számos egyéb, informális 
eleme is van a munkamoráltól kezdve a korrupcióig. A tartós növekedés feltételeinek néhány vonatkozására a 4.7. alfejezetben térünk vissza.

Végül érdemes újfent hangsúlyozni, hogy a térség országainak többsége kis, nyitott gazdaságnak tekinthető. A külső gazdasági kapcsolódások jelentőségét emelik ki a folyófizetésimérleg-korlátos modellek: egy kis, nyitott gazdaság exportbővülés, illetve tőkebeáramlás révén tud növekedni. Másik oldalról: ha az exportpiacok teljesítménye romlik és elapad a tőkebeáramlás, az óhatatlanul lassítja a növekedést ezekben az országokban is. (4.6. alfejezet) 


\section{A GAZDASÁGI NÖVEKEDÉS EMPÍRIÁJA}

\subsection{Bevezetés}

Az előző fejezetben bemutatott növekedési modellek fontos összefüggésekre hívták fel a figyelmet: ezek alapján kihangsúlyozhatjuk a fizikai tőke felhalmozásának, a munkaerő képzettségének (humántőke-ellátottságának) fontosságát, vagy az intézményrendszer lényeges szerepét a gazdasági növekedés folyamatában. A kvalitatív megállapításokon túl viszont az is fontos, hogy az egyes magyarázó tényezők hatását számszerüsíteni lehessen. Ennek három módszerét ismertetem az alábbiakban: a növekedési számvitelt, a fejlettségi számvitelt és a növekedési regressziók eszköztárát. Röviden áttekintem a módszertanok lényegi vonásait és néhány gyakran idézett, általános eredményét, majd a fejezet végén kitérek a kelet-közép-európai térségre vonatkozó növekedési és fejlettségi számviteli eredményekre.

\subsection{Növekedési számvitel}

A növekedési számvitel (growth accounting) módszertanának lényege annak megvizsgálása, hogy egy bizonyos ország adott időszakban elért kibocsátás-bővülése milyen mértékben vezethető vissza az egyes növekedési tényezők alakulására. A módszer alapvetően a Solow-modellre, illetve annak kiterjesztéseire épít. A modell értelmében az egyensúlyi pályán a technológiai fejlődés szabja meg a növekedés ütemét, de rövidebb távon, az egyensúlyi pálya felé tartó konvergencia során már nem egyértelmü a helyzet. A tőkeellátottság és a termelékenység növekedése együtt eredményezi az egy főre jutó kibocsátás emelkedését, így van értelme megvizsgálni az egyes tényezők szerepét.

Tekintsük a tőkében és munkában állandó mérethozadékú $Y=A \cdot F(K ; L)$ termelési függvényt! Mindkét oldalt az idő szerint deriválva azt kapjuk, hogy

$$
\dot{Y}=\dot{A} \cdot F(K ; L)+A \cdot(\partial F / \partial K \cdot \dot{K}+\partial F / \partial L \cdot \dot{L}) \text {. }
$$

Mindkét oldalt elosztjuk $Y$-nal, így

$$
\dot{Y} /_{Y}=\dot{A} /_{A}+(\partial F / \partial K \cdot \dot{K}) /_{F(K ; L)}+(\partial F / \partial L \cdot \dot{L}) /_{F(K ; L)},
$$

majd a jobboldali tagokat $A$-val, valamint $K$-val, illetve $L$-lel bővítve 


$$
\dot{Y} /_{Y}=\dot{A} /_{A}+\left(A \cdot \partial F / \partial K \cdot K /{ }_{Y}\right) \cdot(\dot{K} / K)+(A \cdot \partial F / \partial L \cdot L / Y) \cdot\left(\dot{L} /_{L}\right)
$$

Az $A \cdot \partial F / \partial K$, illetve $A \cdot \partial F / \partial L$ tagok a tőke, illetve a munka határtermékét adják meg. Ha azt feltételezzük, hogy a termelési tényezők piacán tökéletes verseny van, akkor a tényezőárak megegyeznek ezekkel a határtermékekkel. Így $(A \cdot \partial F / \partial K \cdot K) /_{Y}$, valamint $(A \cdot \partial F / \partial L \cdot L) /_{Y}$ nem más, mint a tőke- és munkajövedelmek kibocsátáson belüli aránya ${ }^{51}$, amit a korábbiaknak megfelelően $\alpha$-val és $(1-\alpha)$-val jelölhetünk:

$$
\dot{Y} /_{Y}=\dot{A} /_{A}+\alpha \cdot \dot{K} / K+(1-\alpha) \cdot \dot{L} /_{L} .
$$

Ha az egy főre jutó kibocsátás alakulását vizsgáljuk, akkor mindkét oldalból levonhatunk $\dot{L} / L^{-\mathrm{t} \text { : }}$

$$
\dot{Y} /_{Y}-\dot{L} /_{L}=\dot{A} /_{A}+\alpha \cdot \dot{K} /_{K}-\alpha \cdot \dot{L} /_{L}=\dot{A} /_{A}+\alpha \cdot\left(\dot{K} /_{K}-\dot{L} / L\right),
$$

vagyis intenzív formában, az egy főre jutó mennyiségekkel kifejezve:

$$
\dot{y} / y=\dot{A} /_{A}+\alpha \cdot \dot{k} / k_{k} \text { (Solow, 1957, pp. 312-313) }
$$

Így tehát az egy főre jutó kibocsátás alakulása visszavezethető a tőkeellátottság változásának hatására, illetve az úgynevezett Solow-maradékra $\left(\dot{A} /{ }_{A}\right)$, vagyis a teljes tényezőtermelékenység (total factor productivity, TFP) növekedésére. ${ }^{52} \mathrm{Ha}$ rendelkezünk a GDP és a tőkeállomány idősorával, valamint ismerjük a tőkejövedelmek GDP-n belüli arányát, akkor ez a dekompozíció elvégezhető. ${ }^{53}$

Solow (1957) ezzel a módszertannal vizsgálta a technológiai fejlődés szerepét az amerikai gazdaságban az 1909-1949 közötti időszakra vonatkozóan. Adatsorai nem tartalmazták a mezőgazdaságot, illetve élt egy egyszerüsítéssel: a termelésben felhasznált tőkeállomány idősorát úgy kapta meg, hogy a rendelkezésre álló tőkeál-

\footnotetext{
${ }^{51}$ Ez tehát azt is jelenti, hogy - ahogy a 2.4. alfejezetben is volt róla szó - a kibocsátás egyértelműen felosztható a termelési tényezök jövedelmei között, ezek felett nem keletkezik gazdasági profit.

${ }^{52}$ Hangsúlyozom, hogy a növekedési számvitel ez alapján azt is feltételezi, hogy az egyes tényezöknek (például a fizikai töke felhalmozásának) nincsenek externális hatásai, vagyis növekedésben játszott szerepüket az egyéni megtérülésük (ami a jövedelemarányokban megjelenik) jól leírja. Az mindenképpen igaz, hogy az externális hatások nehezen számszerüsíthetőek, elméleti jelentőségüket azonban többen is kiemelik (lásd például a 2.6. alfejezetben szereplő AK modellt, vagy Lucas, 1988, humántöke-modelljét a 2.7. alfejezetben).

${ }^{53}$ Munkakiterjesztő technikai fejlődés feltételezése esetén másképpen néz ki a Solow-maradék, de a számszerüsítés tekintetében ennek nincs érdemi jelentősége, hiszen ugyanazokra az idősorokra van szükség, és a dekompozíció ez esetben is az $\dot{y} / y=\alpha \cdot \dot{k} / k+R$ alakot ölti, ahol $R$ jelöli a Solowmaradékot.
} 
lományt megszorozta a munkaerő-állományon belül a foglalkoztatottak arányával. Ez azt a feltételezést foglalja magában, hogy egy-egy adott időpontban a különböző termelési tényezők rendelkezésre álló mennyiségének ugyanakkora hányadát nem alkalmazzák. Ahogy a szerző fogalmaz, ez a feltevés „kétségtelenül hibás, de valószínűleg így is közelebb visz az igazsághoz, mint ha nem alkalmaznánk semmilyen korrekciót”. (i.m., p. 314)

A nem mezőgazdasági GNP egy munkaórára jutó értéke átlagosan 1,81 százalékkal nőtt évente a vizsgált időszakban. Ebből nagyjából 0,23 százalékot magyarázott a tőkeellátottság növekedése, míg a többit a technológiai fejlődés. Az adatsorokban jól látható egy töréspont, hiszen az egy munkaórára jutó tőkeállomány nagysága 1931-et követően csökkenésnek indult. Ezt megelőzően az átlagosan 1,71 százalékos GNP-növekedésből 0,75 százalékot magyarázott a tőkefelhalmozás. Az 1931-et követő időszakban viszont az évi 1,93 százalékos jövedelemnövekedést csak a technológiai fejlődés eredményezte, hiszen a tőkeellátottság csökkenése önmagában mintegy 0,47 százalékos GNP-visszaesést okozott volna évente. ${ }^{54}$

Solow (1957) számításai szerint tehát a nagy gazdasági világválság előtti időszakban megközelítőleg 45-55 százalékban magyarázta az egy főre jutó kibocsátás növekedését a tőkefelhalmozás és a technológiai fejlődés, majd a válságot követően egyértelműen utóbbi hatás vált kizárólagossá.

Aghion és Howitt (2009) is ismertet a fejlett országok 1960-2000 közötti növekedésére vonatkozó eredményeket. A 22 vizsgált ország mintájában az éves növekedési ütem súlyozatlan átlaga 2,41 százalék volt, amiből 0,80 százalék a tőkemunka arány emelkedésére, 1,61 százalék pedig a teljes tényezőtermelékenység javulására vezethető vissza. Összességében tehát mintegy egyharmad-kétharmad arányban magyarázta a két tényező a négy évtized alatt megfigyelhető gazdasági növekedést. Az egyes országok között természetesen volt különbség, azonban mindenhol a TFP szerepe volt erőteljesebb: az egyik véglet Olaszország 52 százalékos, a másik Görögország 86 százalékos TFP-részesedéssel. (i.m., p. 109)

\footnotetext{
${ }^{54}$ Az itt szereplő, részidőszakokra vonatkozó eredményeket Solow (1957, p. 315) adatsorai alapján számítottam ki az átlagos tőkejövedelem-arányt (1909-1931 között 33,8 százalék, 1931-1949 között 34,4 százalék, míg a teljes idöszakra 34,1 százalék) felhasználva. Az eredeti cikkben a szerző évről évre rekonstruálta az $A$ idősort mindig az aktuális jövedelemrészesedést felhasználva. Mivel ez az időszak során 31,2 és 39,7 százalék között ingadozott, ezért ez okoz némi eltérést a kapott eredményekben, de ennek mértéke nem jelentős, a technológiai fejlődés éves átlagos ütemére nézve egytized százalékponton belüli.
} 
Az egyik leghíresebb növekedési számviteli elemzés Young (1995) nevéhez füződik, aki az eddig bemutatottaktól alapvetően eltérő eredményre jutott a keletázsiai „,kis tigrisek” (Dél-Korea, Hong Kong, Szingapúr, Tajvan) 1966-1990 közötti rendkívül gyors növekedési periódusát elemezve. Módszere annyival volt összetettebb a fentebbieknél, hogy kevésbé aggregált termelési tényezőkkel dolgozott, vagyis külön vizsgált eltérő tőkekategóriákat (például épületek, járművek, gépek), valamint munkavállalói csoportokat (például nem, kor, végzettség szerint). Legfontosabb eredménye, hogy a növekedés döntő részben a termelési tényezők felhalmozására (fizikaitőke-beruházások, a munkaerö-állomány bővülése, képzettségének növekedése, illetve a munkaerő átáramlása az ipari szektorba) vezethető vissza, és csak kis mértékben a teljes tényezőtermelékenység növekedésére.

Halmai és Vásáry (2011) nem a múltbeli növekedési teljesítmény elemzésére, hanem a potenciális kibocsátás közeljövőben várható alakulásának elörejelzésére alkalmazta a növekedési számvitel módszertanát. Cikkükben azt vizsgálták, hogy az Európai Unió egyes országcsoportjainak várhatóan hogyan alakul a potenciális növekedési üteme a 2010-2014 közötti időszakban, illetve, hogy ebben mekkora az egyes tényezők (munka, tőke, TFP) részesedése. Az EU egészére azt kapták, hogy a potenciális növekedési ütem 2014-re megközelíti a pénzügyi válság előtti ütemet, méghozzá mintegy 60 százalékban a teljes tényezőtermelékenység javulása, 40 százalékban a tőkeállomány növekedése révén. Érdemes külön kiemelni a külső egyensúlytalanságuk által sérülékennyé ált országok csoportját (balti államok, Bulgária, Magyarország és Románia), melyekre vonatkozóan tartósan alacsony potenciális növekedési ütemet jeleztek előre, a munkatényező folyamatos negatív hozzájárulásával és minimális termelékenységjavulással. Vagyis ezekre az országokra azt kapták, hogy noha a tőke bővülési üteme nem éri el a válság elötti szintet, ezzel együtt is ez az egyetlen várható érdemi növekedési faktor. (i.m., p. 478)

Malecek (2015) a válságot követő időszaknak (2010 első negyedévétől 2013 első negyedévéig) a tényleges teljesitményét már visszatekintve vizsgálta, és eredményei részben ellentmondanak a fentebb idézett elörejelzéseknek. Az EU egészét tekintve a munkainput csökkenése pontosan kiegyenlítette a tőkefelhasználás növekedését, így a GDP bővülés mértéke megegyezik a teljes tényezőtermelékenység javulásának ütemével. A Halmai és Vásáry (2011) által együtt kezelt, a sérülékeny országok csoportjába sorolt gazdaságok tényleges teljesítményében jelentős különbségek figyelhetők meg 2010-2013 között. A balti államokban gyors ütemü GDP-növekedés 
volt jellemző, amit 60-63 százalékában a TFP javulása magyaráz, de emellett a tőke és munka hozzájárulása is pozitív. A másik három országban azonban valóban mérsékeltebb volt a kibocsátás emelkedése, és ebben is a legjelentősebb pozitív tényező valóban a tőkeállomány növekedése volt. A munka mennyisége mindhárom országban csökkent, míg a teljes tényezőtermelékenység tekintetében vegyes a kép (Bulgáriában jelentős pozitív hozzájárulása volt a növekedéshez, míg Magyarországon és Romániában csökkent). (Malecek, 2015, p. 534)

A növekedési számvitel módszertanával kapcsolatban két problémát mindenképpen fel kell vetni. Az egyik a mérés ügye: a következtetések helyessége erősen függ a felhasznált adatsorok minőségétől. Legalább három helyen is el lehet csúszni e tekintetben. Egyrészt a fizikai tőke idősorával kapcsolatban azt kell kiemelni, hogy ideális esetben az adott időszak alatt felhasznált tőkeszolgáltatás (flow) lenne érdekes a növekedési számvitel szempontjából (ugyanúgy, ahogy a termelésben felhasznált munkaórák száma szerepel a vizsgálatokban, nem pedig a rendelkezésre álló munkaerő-állomány). Ez azonban nem igazán mérhető, ehelyett jobb híján a tőkeállomány (stock) idősorát lehet használni ${ }^{55}$, ami persze önmagában is messze nem tökéletes, hiszen a tőkejavak minősége folyamatosan javul, amit viszont nehéz számszerüsíteni. Hsieh (2002) azt mutatja be, hogy a valóságban a Young (1995) által kimutatott évi 0,2 százaléknál lényegesen nagyobb, a többi kelet-ázsiai országhoz hasonló mértékü volt a teljes tényezőtermelékenység növekedése Szingapúrban is, és a mérési probléma pont abban keresendő, hogy a felhasznált nemzetiszámla-adatok lényegesen felülbecsülték a beruházásokat, így értelemszerüen a tőkeállományt is.

Másrészt ugyanígy csak közelítő megoldással lehet élni a humán tőke tekintetében $^{56}$, hiszen az iskolázottság alakulása önmagában nem képes teljes mértékben megragadni az emberi tőke felhalmozódását: nyilván számít az iskolai képzés minősége is, csakúgy, mint a munka közben elsajátított ismeretek stb.

Harmadrészt meg kell említeni, hogy a jövedelemarányok alkalmazása az egyes tényezők növekedésben játszott szerepének becslésében - mint korábban már említettem - szintén lényeges és vitatható feltevésekre épül: tökéletes verseny mind a végtermék, mind a termelési tényezők piacain, illetve az externális hatások hiánya.

\footnotetext{
55 És esetleg alkalmazni valamilyen korrekciót rajta Solow (1957) szellemében.

${ }^{56}$ Noha Solow (1957) alapmodellje nem tartalmaz humán tőkét, de például Dombi (2013) és Kónya (2015) 3.5. alfejezetben idézett modelljei igen.
} 
Az állandó mérethozadék általánosabb problémája kapcsán pedig visszautalok a 2.4. alfejezet végén elmondottakra.

A másik lényeges probléma az eredmények értelmezésével kapcsolatban merülhet fel. Az, hogy a gazdasági növekedést dekomponáljuk, és visszavezetjük bizonyos tényezőkre, illetve a termelékenység javulására, nem jelenti azt, hogy ezek a faktorok ténylegesen ilyen arányban „okoznák” a növekedést. Erre hívja fel a figyelmet Aghion és Howitt (2009, pp. 112-113) következő fejtegetése is:

A fejlett országokról fentebb bemutatott eredmény (a növekedés átlagosan egyharmada a tőkeellátottságra, kétharmada a teljes tényezőtermelékenységre vezethető vissza) összhangban van a munkakiterjesztő technológiai fejlődést tartalmazó Solow-modell egyensúlyi növekedési pályájával kapcsolatban elmondottakkal. A szokásoknak megfelelően tegyük fel, hogy Cobb-Douglas-típusú termelési függvény írja le a gazdaság müködését:

$$
Y=K^{\alpha} \cdot(A \cdot L)^{1-\alpha} .
$$

Ez esetben a teljes tényezőtermelékenység $A^{1-\alpha}$, aminek növekedési üteme a technológiai fejlődést leíró $A$ változó növekedési ütemének $(1-\alpha)$-szorosa. Az egyensúlyi növekedési pályán az egy före jutó kibocsátás az $A$-val megegyező ütemben bővül, $\alpha$ pedig a tőkejövedelmek aránya a GDP-n belül, ami a legtöbb ország esetében megközelítőleg egyharmad. Vagyis a modell egyensúlyi növekedési pályáján a teljes tényezőtermelékenység növekedési üteme megegyezik az egy főre jutó kibocsátás növekedési rátájának kétharmadával, ami pontosan a fejlett országokra kimutatott átlagos eredmény. Mégsem állíthatjuk, hogy a növekedés maradék egyharmadát a tőkefelhalmozás okozná, hiszen a Solow-modellben az egyensúlyi növekedés egyedüli oka a technológiai fejlődés. Csak éppen e fejlődés hatása lecsapódik a tőke-munka arány növekedésében is, ami tehát nem ok, hanem következmény. ${ }^{57}$

Mindez természetesen nem azt jelenti, hogy a növekedési számviteli vizsgálatok haszontalanok lennének, csak azt, hogy értelmezésükkel, a levont következtetésekkel kapcsolatban óvatosnak kell maradni.

${ }^{57} \mathrm{Ez}$ indokolja a dekompozíciós egyenlet Hall és Jones (1999) által is alkalmazott módosítását, amit a következő fejezetpontban be is mutatok. 


\subsection{Fejlettségi számvitel}

A növekedési számvitellel rokon módszertan az ún. fejlettségi számvitel (development accounting) $)^{58}$, mely egy adott időpontban egy választott referenciaországhoz viszonyított GDP-lemaradást dekomponálja az egyes tényezők szerint.

Hall és Jones (1999) 127 ország 1988-as adatait használta egy ilyen vizsgálat lefolytatására. Állandó mérethozadékú, munkakiterjesztő technológiai fejlődést tartalmazó, Cobb-Douglas-típusú termelési függvényből indultak ki:

$$
Y=K^{\alpha} \cdot(A \cdot H)^{1-\alpha},
$$

ahol $H=e^{\rho(E)} \cdot L$. Ebben az összefüggésben $E$ jelöli az iskolai évek átlagos számát, a $\rho(E)$ függvény pedig ezeknek a megtérülését, vagyis (piaci) értékét adja meg. ${ }^{59} \mathrm{~A}$ munkaerő-állomány létszámával $(L)$ leosztva mindkét oldalt azt kapjuk, hogy

$$
y=Y / L=(K / L)^{\alpha} \cdot(A \cdot h)^{1-\alpha},
$$

ahol $h=e^{\rho(E)}$ egy munkás átlagos humán tőkéjének értéke. Ahogy az előző alfejezet végén szerepelt, ebben az esetben további átalakítások nélkül akkor is a tőkeellátottság különbségének tulajdonítanánk a kibocsátásban mutatkozó eltérések $\alpha$ hányadát, ha valójában csak a munka termelékenységében lenne különbség, és ez vezetne más-más egyensúlyi tőke-munka arányhoz az egyes országokban.

Így ehelyett egy más átalakítást célszerü követni, és az eredeti termelési függvény két oldalát inkább $Y^{\alpha}$-nal osztjuk le:

$$
Y^{1-\alpha}=(K / Y)^{\alpha} \cdot(A \cdot H)^{1-\alpha} .
$$

Ha mindkét oldalt $1 /(1-\alpha)$ hatványra emeljük, azt kapjuk, hogy

$$
Y=(K / Y)^{\frac{\alpha}{1-\alpha}} \cdot A \cdot H
$$

amiből a munkaerő-állománnyal osztva eljutunk a szerzők által a becslésre használt egyenletig:

$$
y=(K / Y)^{\frac{\alpha}{1-\alpha}} \cdot A \cdot h . \text { (i.m., pp. 87-88) }
$$

\footnotetext{
${ }^{58}$ A magyar szakirodalomban meghonosodott a fejlődés-számvitel elnevezés (Dombi, 2013), azonban - tekintve, hogy nem az időbeli fejlődés, hanem adott időszaki fejlettségbeli eltérések állnak a vizsgálat fókuszában - a fejlettségi számvitel elnevezés szerencsésebb.

${ }^{59}$ A szakirodalomban elterjedt megoldás szerint a $\rho(E)$ függvényt szakaszosan lineárisnak szokás feltételezni: $\rho(E)=r_{1-4} \cdot E$, ha $E \leq 4, \rho(E)=r_{1-4} \cdot 4+r_{5-8} \cdot(E-4)$, ha $4<E \leq 8$ és $\rho(E)=$ $=\left(r_{1-4}+r_{5-8}\right) \cdot 4+r_{9-} \cdot(E-8)$, ha $8<E$, ahol $r_{1-4}, r_{5-8}$ és $r_{9-}$ az elsö és második négy év, illetve az afölötti évek átlagos megtérülési rátája.
} 
Az egy főre jutó GDP, a tőke-kibocsátás arány és az átlagos iskolázottság ismeretében ebből az összefüggésből becsülhető az egyes országok munkatermelékenysége, majd meghatározható az egyenletben szereplő három tag $\left((K / Y)^{\frac{\alpha}{1-\alpha}}, A\right.$ és h) hozzájárulása az Egyesült Államokhoz viszonyított jövedelmi lemaradáshoz. Az 1. táblázat néhány országra mutatja az eredményeket.

1. táblázat: Az Egyesült Államokhoz viszonyított 1988-as jövedelmi lemaradás, illetve a tőkeintenzitás, iskolázottság, valamint a munkatermelékenység hozzájárulása

\begin{tabular}{|c|c|c|c|c|}
\hline Ország & GDP per fö & Tőkeintenzitás & Iskolázottság & $\begin{array}{c}\text { Munka- } \\
\text { termelékenység }\end{array}$ \\
\hline NSZK & 0,818 & 1,118 & 0,802 & 0,912 \\
\hline Egyesült Kir. & 0,727 & 0,891 & 0,808 & 1,011 \\
\hline Japán & 0,587 & 1,119 & 0,797 & 0,658 \\
\hline Szovjetunió & 0,417 & 1,231 & 0,724 & 0,468 \\
\hline India & 0,086 & 0,709 & 0,454 & 0,267 \\
\hline Kína & 0,060 & 0,891 & 0,632 & 0,106 \\
\hline Átlag & 0,296 & 0,853 & 0,565 & 0,516 \\
\hline
\end{tabular}

Saját szerkesztés Hall és Jones (1999) I. táblázata alapján

Megjegyzés: mind a négy változó esetében az Egyesült Államok a referencia, vagyis az USA vonatkozó értéke 1. A második oszlop értéke a harmadik-ötödik oszlop értékeinek szorzataként kapható meg (kivéve az átlag esetében).

Látható, hogy a legkisebb eltérés a tőkeintenzitásban figyelhető meg, több ország e tekintetben meg is haladta az Egyesült Államok értékét (többek között a lényegesen szegényebb Szovjetunió is). Az iskolázottság magyarázóereje már jelentősebb, a legfontosabb azonban a munkatermelékenység - főleg a legszegényebb országok esetében. India és Kína esetében is ez a helyzet, csakúgy, mint az afrikai országok körében: a jövedelmi lemaradások döntő hányada a munka termelékenységében mutatkozó különbségekre vezethető vissza. (i.m., pp. 91-92) Ekkora eltérések nincsenek az elérhető technológiai színvonalban, a szerzők ehelyett az intézmények (az ő szóhasználatukban: a társadalmi infrastruktúra) szerepét hangsúlyozzák a termelékenységi és azon keresztül a jövedelmi differenciák kialakulásában.

Mankiw, Romer és Weil (1992) korábban már említett tanulmánya bizonyos tekintetben szintén ehhez az empirikus irányzathoz köthető, noha esetükben nem a fentiekhez hasonló dekompozícióról van szó. Ahogy a 2.7. alfejezetben bemutattam, tanulmányuk a Solow-modell humán tőkével kiterjesztett változatára épít. A modell értelmében az egyensúlyi növekedési pályán az egyes országok paramétereitől füg- 
getlenül a technológiai fejlödés üteme adja meg az egy főre jutó jövedelem növekedésének sebességét, azonban ennek az egyensúlyi pályának a szintjére már hatnak ezek a paraméterek. Így ezek hatása már vizsgálható ökonometriai módszerekkel keresztmetszeti mintán, tehát itt is az adott időszaki jövedelemszintek állnak az elemzés fókuszában.

\subsection{Növekedési regresszió}

A növekedéselmélethez kapcsolódó empirikus irodalom harmadik vonulatát a növekedési regressziók képviselik. Ezek - az előzőekkel szemben - közvetlenül nem kötődnek az elméleti modellek egyenleteihez, bár maguk a teóriák nyilván orientálják a kutatókat. Ezzel együtt is azt mondhatjuk, hogy tisztán empirikus megközelítésből vizsgálják a gazdasági növekedés kérdését. Az alapvető módszertan a keresztmetszeti ökonometria eszközeit használja: a függő változó a mintában szereplő országok adott időszakban produkált gazdasági növekedése, míg a magyarázó változók között ezen országok különféle gazdasági és társadalmi mutatói szerepelhetnek.

A leghíresebb átfogó növekedési regressziós vizsgálat Barro (1991) nevéhez füződik, aki 98 ország 1960-1985 közötti adatait elemezte. Összesen 29 regressziót futtatott le független változók különböző kombinációival, ebből 20 esetben volt az egy főre jutó reál GDP növekedési üteme a függő változó (a többi regresszió a népszaporulat különböző változóira, illetve a beruházásokra vonatkozott). Vizsgálataiból számos fontos eredmény kirajzolódott.

Egyrészt nem figyelhetö meg abszolút konvergencia, az átlagos növekedési ütem és a kezdeti jövedelemszint között önmagában nincs szignifikáns kapcsolat (a korrelációs együttható 0,09). Feltételes konvergencia azonban egyértelműen kimutatható, ehhez elegendő, hogy a kezdeti jövedelemszint mellett a humán tőke valamilyen mérőszáma is szerepeljen a regresszióban. Erre a szerző az 1960-as alap- és középfokú beiskolázási arányokat használta. Ezzel kapcsolatban felmerül az az észrevétel, hogy a beiskolázási arány inkább az adott időszaki humántőke-beruházást mutatja, nem pedig a korábbi beruházások révén felhalmozott állományt, de közelítő megoldásnak így is megfelel. A két humántőke-mérőszám szignifikánsan pozitív, a kezdeti jövedelemszint pedig szignifikánsan negatív együtthatót kapott, ami egyfelől az oktatás fontosságát mutatja, másrészt pedig azt, hogy adott képzettségü munkaerő mellett már érvényesül az a kiegyenlítő hatás, hogy a kezdetben szegényebb országok gyorsabban, a kezdetben gazdagabbak pedig lassabban növekednek. 
Erős pozitív korreláció figyelhető meg azonban a kezdeti jövedelemszint és iskolázottság között (0,77-es korrelációs együttható), így a legtöbb ország esetében ezek az ellentétes hatások kiegyenlítik egymást, ennek köszönhető az abszolút konvergencia hiánya. Valójában azok a szegényebb országok voltak képesek gyorsabb növekedésre, amelyek a jövedelemszintjükhöz képest relatíve több oktatási beruházást hajtottak végre (nagyobb beiskolázási ráták). Tipikusan ez a minta jellemző a kelet-ázsiai országokra (Japán, Dél-Korea, Tajvan). Ezzel szemben az afrikai országok és az olajexportáló államok többségében alacsonyabbak voltak a beiskolázási mutatók, mint ami a jövedelemszintjüknek megfelelt volna, ez magyarázza a lassabb gazdasági növekedést a vizsgált időszakban. (i.m., pp. 417-419)

A fizikai tőke szerepét hangsúlyozó növekedési modellek (például a HarrodDomar-modell vagy a Solow-modell) következtetéseivel összhangban a beruházási ráta együtthatója egyértelmüen pozitív: a tőkefelhalmozás fontos forrása a növekedésnek. A nagyobb átlagos gyermekszám viszont ellenkező hatású, ez is összhangban van a Solow-modell eredményeivel. Ez értelmezhető úgy is, hogy a kevesebb gyermek a szülői erőforrások koncentrációját eredményezi, ami miatt képzettebbek lesznek és nagyobb lesz jövedelemtermelő képességük.

A kormányzati fogyasztás nagyobb GDP-aránya lassabb gazdasági növekedéssel jár együtt. Egyrészt mivel kevesebb magánberuházáshoz vezet (ezt nevezzük kiszoritási hatásnak), másrészt adott beruházási ráta mellett is megfigyelhető a negatív hatás, vagyis van a beruházások visszavetésén túlmutató hatás is. Ezt magyarázhatja a nagyobb kiadási szint finanszírozásához szükséges adók által okozott torzítás (holtteher-veszteség), vagy akár a nagyobb költségvetéssel összefüggő korrupció. (i.m., p. 430-432)

Egyéb változók is megjelennek Barro (1991) regresszióiban. Egyrészt a politikai instabilitás két mérőszámának (forradalmak és puccsok száma évente, illetve az egymillió főre jutó politikai gyilkosságok száma évente) szintén negatív az együtthatója - közvetlenül a növekedésre és közvetve a beruházásokon keresztül is. Másrészt a kilenc, mintában szereplő szocialista ország szignifikánsan gyengébb növekedési teljesítményt ért el. Harmadrészt a mesterségesen magasan vagy mesterségesen alacsonyan tartott beruházási árak révén megjelenített piaci torzítások szintén negatív kapcsolatban állnak a gazdasági növekedéssel. Negyedrészt mindezek mellett az afrikai és latin-amerikai országokra bevezetett dummy változók is szignifikáns negatív együtthatót kaptak, ami azt mutatja, hogy ezeknek az országoknak vannak olyan (in- 
tézményrendszeri vagy egyéb) jellemzői, amelyeket a többi változó nem képes megragadni, és amelyek hátráltatják a gazdasági növekedést. (i.m., p. 432-436)

Bár alapvetően a jövedelmi szinteket vizsgálták, Mankiw, Romer és Weil (1992) tanulmányának egyik fejezete is tartalmaz növekedési regressziós vizsgálatokat. Ezek eredményei hasonlóak az előzőekben leírtakhoz: megfigyelhető a feltételes konvergencia jelensége, a beruházási rátának és az iskolázottságnak szignifikánsan pozitív, míg a népességnövekedésnek negatív az együtthatója. (i.m., pp. 424-429)

Egy korábbi tanulmányomban (Németh, 2011c) magam is futtattam hasonló növekedési regressziókat. Az 1970-2009 és 1990-2009 közötti időszakot vizsgáltam különböző országcsoportok adatait felhasználva. A különböző specifikációjú modellek (összesen 40) eredményei alapján a következő - a fentiekkel összhangban lévő következtetések adódtak: a beruházási ráta szignifikánsan pozitív, a termékenységi ráta szignifikánsan negatív kapcsolatban áll a növekedési ütemmel, az esetek többségében az iskolázottsági mutatók együtthatója is szignifikánsan pozitív lett. A magyarázó változókra kontrollálva egyértelmüen kirajzolódott a feltételes konvergencia jelensége is.

Ezekkel a regressziós vizsgálatokkal kapcsolatban fontos problémaként merül fel az okság és endogenitás kérdése: a két változó közötti szignifikáns regressziós együttható önmagában nem jelent feltétlenül oksági kapcsolatot. Elképzelhető, hogy pontosan a függö(nek feltételezett) változó hat a független(nek gondolt) változóra, nem pedig fordítva. Egy másik lehetőség, hogy van egy nem megfigyelt közös ok, ami meghatározza mindkét változó alakulását, és így az együttmozgásukat is ez magyarázza. Ez az endogenitási probléma nehezen kiszürhető, ha - mint Barro (1991) tanulmányában a beruházási ráta, a kormányzati fogyasztás, vagy akár a politikai stabilitás mérőszámai esetében - a vizsgálati időtáv átlagértékeit használjuk. Ebből a szempontból szerencsésebb lenne a kezdeti értékeket használni, azonban ekkor meg az a kérdés merül fel - a Barro-féle vizsgálat kontextusában -, hogy valóban érdemben hat-e az 1960-1985 közötti időszak egészének gazdasági növekedésére, hogy 1960-ban mekkora volt a beruházási ráta.

Ezt a problémát orvosolhatja, ha az egyszerü keresztmetszeti regressziók helyett panelbecsléseket alkalmazunk, és rövidebb (mondjuk három- vagy ötéves) szakaszokra bontjuk a teljes vizsgált időhorizontot. Ebben az esetben egyértelmü, hogy a rövidebb szakaszok elején megfigyelt kezdőértékek kihatnak e szakaszok egészére. Természetesen ez a megoldás sem tökéletes, hiszen így a hangsúly a hosszú távú 
átlagos növekedési ütemről áttevődik a rövidebb időszakok növekedési teljesítményére, amit már ciklikus elemek is jelentős mértékben befolyásolnak.

Ugyanúgy, ahogy a növekedési számvitel kapcsán megtettem, itt is fontos kiemelni, hogy azzal együtt is, hogy nem tökéletes a növekedési regressziók módszertana, hasznos következtetésekre vezethet alkalmazásuk.

\subsection{A térségre vonatkozó növekedési és fejlettségi számviteli eredmények}

Már a 3.2. alfejezetben is idéztem két tanulmányt (Halmai és Vásáry, 2011, Malecek, 2015), amelyek az Európai Unió többi országa mellett a kelet-közép-európai tagállamokat is vizsgálták, az alábbiakban viszont két olyan cikk eredményeit mutatom be, amelyek kifejezetten a volt szocialista országok, illetve Magyarország teljesítményét elemezték a növekedési és fejlettségi számvitel módszertanával.

Dombi (2013) a 2004-ben és 2007-ben csatlakozott kelet-közép-európai EUtagállamok 1995-2012 közötti növekedését vizsgálta növekedési számviteli módszerekkel. Aggregált termelési tényezőkkel dolgozott, de a felhasznált munkaerő menynyisége mellett figyelembe vette az átlagos iskolázottsággal mért minőségét is. Az alkalmazott összefüggés tehát

$$
\dot{Y} /_{Y}=\dot{A} /_{A}+\alpha \cdot \dot{K} /_{K}+(1-\alpha) \cdot \dot{H} /_{H},
$$

ahol $H=e^{\rho(E)} \cdot L$ a minőséggel kiigazított munkaerő-felhasználás. A vizsgálat időhorizontját három szakaszra bontotta a szerző (1996-2001, 2002-2007, 2008-2012), ezekre külön közli eredményeit. Az első időszakban a növekedés domináns hajtóereje Bulgária és Szlovénia kivételével a tőkefelhalmozás volt, míg a munkaerőinput hat országban is visszaesett. A második időszakban már csak Romániában csökkent a felhasznált munka (minőséggel korrigált) mennyisége, míg a tőke és a teljes tényezőtermelékenység tekintetében megosztott a kép: a balti államokban, Bulgáriában, valamint (jóval kisebb mértékben) Lengyelországban és Magyarországon továbbra is a tőkefelhalmozás bírt elsődleges jelentőséggel, a másik négy országban viszont a termelékenység javulása. A 2008-at követő időszakban az országok felében csökkent a GDP. A termelékenység mindenhol visszaesett, Lengyelország és Szlovákia kivételével a munkaerő-felhasználás is, vagyis a tőkeállomány az egyetlen, ami a növekedés irányába mutatott, és tompította, illetve ellensúlyozta a másik két tényező hatását. Mindent összevetve az adatokból egy extenzív, beruházás-orientált növekedési modell rajzolódik ki. 
Dombi (2013) fejlettség-számviteli elemzést is végzett a kelet-közép-európai országokra vonatkozóan, Németországot választva referenciaországnak. Növekedési számviteli vizsgálatához hasonlóan az

$\ln \left(Y / Y_{R}\right)=\ln \left(A / A_{R}\right)+\left(\alpha+\alpha_{R}\right) / 2 \cdot \ln \left(K / K_{R}\right)+\left(1-\left(\alpha+\alpha{ }_{R}\right) / 2\right) \cdot \ln \left(H / H_{R}\right)$ dekompozíciós formulából indult $\mathrm{ki}^{60}$, ahol az $R$ alsó index mindenhol a referenciaországot jelzi. Az országok közötti méretkülönbség kiküszöbölése érdekében mindkét oldalból ki kell vonni $\ln \left(L / L_{R}\right)$-t így megkapható a használt összefüggés:

$$
\begin{aligned}
\ln \left(Y / L /\left(Y / L_{L}\right)\right. & =\ln \left(A / A_{R}\right)+\left(\alpha+\alpha_{R}\right) / 2 \cdot \ln \left(K / L /(K / L)_{R}\right)+ \\
+ & \left(1-\left(\alpha+\alpha_{R}\right) / 2\right) \cdot \ln \left(e^{\rho(E)} / e^{\rho\left(E_{R}\right)}\right) .
\end{aligned}
$$

Az egy munkaórára jutó GDP különbsége tehát felbontható a teljes tényezőtermelékenységben, a tőke-munka arányban és az iskolázottságban mutatkozó eltérések között:

$$
\begin{aligned}
& \ln \left(Y / L /\left(Y /{ }_{L}\right)_{R}\right)=\ln \left(A / A_{R}\right)+\left(\alpha+\alpha_{R}\right) / 2 \cdot \ln \left(K / L /\left(K / L_{R}\right)+\right. \\
&+\left(1-\left(\alpha+\alpha_{R}\right) / 2\right) \cdot\left(\rho(E)-\rho\left(E_{R}\right)\right) .
\end{aligned}
$$

A szerző ezt a dekompozíciót 1995-ös és 2012-es adatokon végezte el. Ezek alapján az egy munkaórára jutó GDP tekintetében mindegyik kelet-közép-európai ország közelebb került Németországhoz a vizsgált időszakban. Mindkét időpontra elmondható, hogy a relatív lemaradás legnagyobb részben a töke-munka arány nagy eltéréseire vezethető vissza, míg a teljes tényezőtermelékenység szerepe ennél mérsékeltebb. ${ }^{61} \mathrm{~A}$ munkaerő átlagos iskolázottságában nincs jelentős mértékü különbség a vizsgált országok és Németország között, igaz, itt fontos kiemelni, hogy - mint korábban, a 3.2. alfejezetben volt már szó róla - az iskolai évek átlagos száma csak egy a munkaerő képzettségét és minőségét meghatározó számos tényező közül.

\footnotetext{
${ }^{60} \mathrm{Ne}$ felejtsük el, a növekedési számviteli összefüggésben $\dot{Y} /{ }_{Y}$ nem más, mint $d \ln Y / d t$, ami diszkrét időszaki adatok esetén $\Delta \ln Y$-nak, vagyis $\ln Y_{t}-\ln Y_{t-1}=\ln \left(Y_{t} / Y_{t-1}\right)$-nek felel meg. Így teljesen egyértelmüvé válik a párhuzam.

${ }^{61}$ A kelet-közép-európai tőkefelhalmozás szerepét kihangsúlyozó növekedési számviteli eredményekkel összhangban elmondható, hogy mindegyik vizsgált országban csökkent a tőkeellátottságban megfigyelhető lemaradás Németországhoz képest, de ezzel együtt még 2012-ben is e tekintetben mutatkozott a legnagyobb eltérés. (Dombi, 2013, p. 475)
} 
Kónya (2015) Magyarország 1995-2013 közötti adatait vizsgálta. Modellje a tőke- és munkafelhasználás mellett a kapacitások kihasználtságát is tartalmazza, vagyis az általa használt aggregált termelési függvény az $Y=u \cdot A \cdot K^{\alpha} \cdot H^{1-\alpha}$ alakot ölti, ahol $u$ jelöli a termelési tényezők kapacitás-kihasználtsági fokát. A népességszámmal leosztva $y=u \cdot A \cdot k^{\alpha} \cdot h^{1-\alpha}$, ahol $y$ az egy före jutó GDP, $k$ és $h$ pedig az egy före jutó tőke- és (képzettséggel korrigált) munkainput. Ez alapján a dekompozíciós egyenlet:

$$
\dot{y} / y=\dot{u} / u+\dot{A} / A+\alpha \cdot \dot{k} / k+(1-\alpha) \cdot \dot{h} / h .
$$

Növekedési számviteli felbontása alapján a teljes időszak gazdasági növekedésének mintegy 40 százalékát a fizikai tőke felhalmozása magyarázza. Emellett 1997-2005 között a teljes tényezőtermelékenység növekedése is nagyban hozzájárult az egy före jutó GDP bővüléséhez. A munkainput szerepe inkább csak 1997-2000 között jelentékeny, míg a kapacitás-kihasználtságé ingadozó: a 2009-es GDP-visszaesés nagy részét ez a tényező magyarázza. (i.m., p. 1133)

Emellett egy alternatív felbontás szerint is elemezte a magyar növekedési teljesítményt, hiszen a teljes tényezőtermelékenység javulása a tőkeellátottság növekedését is elöidézi, így - mint arra a 3.2. alfejezet végén már kitértem - a hagyományos növekedési számviteli megközelítés a TFP változásának hatását részben a tőkefelhalmozás következményeként tünteti fel. Az alternatív dekompozíciós egyenlet:

$$
\dot{y} / y=\dot{u} / u+(1 / 1-\alpha) \cdot \dot{A} /{ }_{A}+(\alpha / 1-\alpha) \cdot(K / Y) /(K / Y)+\dot{h} / h .
$$

Ez a felbontás felértékeli a teljes tényezőtermelékenység és a munkainput szerepét is, míg eszerint a tőke hozzájárulása a növekedéshez a 2007-2009 közötti időszakot leszámítva nagyrészt elhanyagolható volt. (i.m., p. 1135-1136) 


\section{A KELET-KÖZÉP-EURÓPAI ORSZÁGOK GAZDASÁGI NÖVEKEDÉSÉNEK TAPASZTALATAI}

\subsection{Bevezetés}

A 2-3. fejezet a növekedéselmélet és a hozzá kapcsolódó empirikus módszertanok általános kérdéseivel foglalkozott. A 4-5. fejezetben rátérek a kelet-közép-európai térség tapasztalatainak vizsgálatára. Előbb a térség elmúlt 25 évben produkált növekedési teljesítményét, illetve e negyedszázad különböző szakaszainak jellegzetességeit mutatom, majd a költségvetési politika témakörére, illetve annak gazdasági növekedéshez kapcsolódó vonatkozásaira térek ki.

A vizsgált országok körét az Európai Unió tizenegy kelet-közép-európai tagállama jelenti: Bulgária, Csehország, Észtország, Horvátország, Lengyelország, Lettország, Litvánia, Magyarország, Románia, Szlovákia, Szlovénia. Fontos kiemelni, hogy ezek mindegyike a volt szocialista blokk tagja, így sok szempontból hasonló kiinduló helyzetben találták magukat 25 évvel ezelőtt. Emellett hasonlóak voltak a kihívások is, amelyekkel szembesültek. A szocialista rendszerből a piacgazdaságba való átmenet komoly gazdasági megrázkódtatást jelentett, és számos hosszabb ideig ható következménye is van. Noha a jogrendszer gyorsan átalakítható, a gazdasági folyamatok átformálódása, és még inkább a társadalmi berendezkedés és attitüdök megváltozása lényegesen tovább tart. A kiinduló helyzet közös vonásai mellett fontos az is, hogy jelenleg mindegyik ország az Európai Unió tagja, ami egy lényeges „,közös nevező” az intézményrendszer tekintetében.

Természetesen a hasonlóságok mellett vannak lényeges különbségek is, mind a szocialista örökség, mind a jelenlegi helyzet, mind a kettő között befutott pálya tekintetében. Hogy csak egy példát emeljek ki, sok tekintetben egészen másként müködött a csehszlovák vagy román ortodox szocializmus, mint a magyar vagy jugoszláv reformrendszerek, így ezek utóhatásai is mások. ${ }^{62}$ Szintén fontos, hogy az örökölt adottságok mellett a választott gazdaságpolitikai megoldásokban is komoly eltérések vannak, részben a kiinduló helyzettel összefüggésben (pályafüggőség), részben attól függetlenül.

\footnotetext{
${ }^{62}$ Benczes (2016) a magyar reformszocializmus máig ható következményeit emeli ki, és az 1968-as Új Gazdasági Mechanizmus által megteremtett „gulyáskommunizmustól” a mai „gulyáspopulizmusig" vezető utat rajzolja fel.
} 
Csaba (2007) is amellett érvel, hogy a „,szovjet modell öröksége egyre kevésbé meghatározó abban a tekintetben, hogy miképpen alakul a növekedés, a müszaki és a gazdasági teljesítmény és a humán fejlettségi mutatók köre", emiatt az „országcsoport egyre kevésbé alkot értelmesen egybefoglalható elemzési közösséget.” (i.m., p. 760, kiemelés az eredetiben) Az állami szerepvállalás különbözőségei alapján az alábbi csoportokba sorolja a térség országait:

(1) Csehország, Lengyelország, Magyarország és Szlovénia - kiterjedt állami szerepvállalás, 40-45 százalék feletti jövedelem-újraelosztási ráta;

(2) Észtország, Lettország, Litvánia és Szlovákia - kevésbé aktív állam 33-37 százalékos újraelosztási rátával;

(3) Bulgária, Románia (és az akkor még EU-n kívüli Horvátország) - a kiadások még alacsonyabb GDP-aránya, emellett szektorális jellegzetességek is (agrárium térségi átlagnál nagyobb aránya a termelésben és a foglalkoztatottságban egyaránt). ${ }^{63}$ (p. 761)

Elismerve az egyes esetek különbözőségeit, azt gondolom, hogy ezzel együtt is vannak lényegi hasonlóságok is a vizsgált országok helyzetében és teljesítményében. Ezek alapján lehet olyan megállapításokat tenni, amelyek - ha nem is mindegyikre, de - az országok többségére érvényesek. Az alábbiakban ilyen megállapítások megfogalmazására törekszem. Másrészt ezek az országok a bemutatott adatokból kirajzolódó eltérések tekintetében is releváns viszonyítási alapot jelentenek egymásnak.

A fejezet tehát nem kifejezetten a magyar teljesítményt és gazdaságpolitikai döntéseket vizsgálja, hanem a régió egészét. A magyar eset értelemszerüen különösen fontos számunkra (illetve azt gondolom, külső szemlélő számára is érdekes), ezért a dolgozat végi konklúzióban külön kitérek a magyar tapasztalatokra és kilátásokra. Bod (2014) részletesen foglalkozik a magyar gazdaságpolitika heterodoxiájával egészen a reformszocializmustól a mai „unortodox” gazdaságpolitikai döntésekig. Ennek egyfelől van nemzetközi vonatkozása, háttere: az európai centrumhoz viszonyított periféria-helyzet, illetve az ebböl következő folyamatos felzárkózási törekvés részben magyarázza a fejlettebb országokban bevált receptektől

${ }^{63}$ Csaba (2007) tanulmánya negyedik csoportként foglalkozik még a Független Államok Közösségének posztszocialista tagországaival is, de ez a csoport e dolgozat vizsgálati fókuszán kívül van. 
való eltérést. A magyar döntések azonban sok esetben a hasonlóan az európai periférián elhelyezkedő országok gyakorlatától is eltérnek. ${ }^{64}$

3. ábra: A reál GDP alakulása a kelet-közép-európai országokban $(1990=100 \%)$

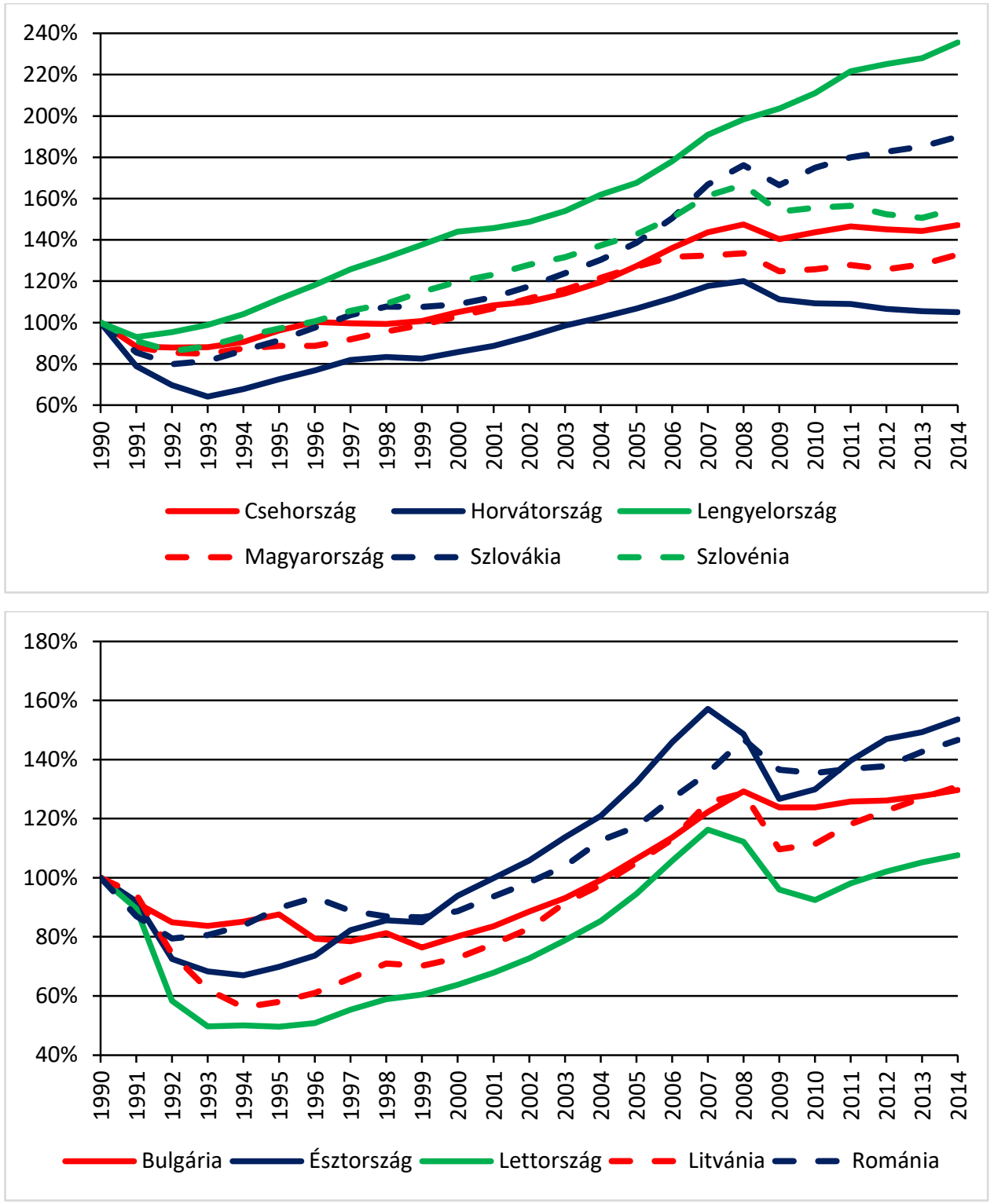

Saját szerkesztés az UNSTATS (2016) adatai alapján

A 4-5. fejezetben számos ábra szerepel ${ }^{65}$ a térségbeli országok gazdasági teljesítményéről, az ezt meghatározó, befolyásoló tényezők alakulásáról. Az idősoros ábrákon az áttekinthetőség kedvéért két csoportban szerepelnek az országok: Csehor-

${ }^{64}$ Bod (2011a, 2011b) alaposan dokumentálja a 2000-es évek magyar gazdaságpolitikájának sajátosságait.

${ }^{65}$ A fontosabb ábrák a föszövegbe illeszkednek, a kevésbé lényeges, a mondanivalót inkább csak kiegészítő ábrákat a Függelékben helyeztem el. 
szág, Horvátország, Lengyelország, Magyarország, Szlovákia és Szlovénia mindig az ábrák felső felén, Bulgária, Észtország, Lettország, Litvánia és Románia pedig az alsó ábrafélen. Ehhez a csoportosításhoz érdemes egy megjegyzést füzni, ugyanis nincs összhangban a Csaba (2007) által képzett, fentebb idézett csoportokkal annak ellenére, hogy a számára is döntő szempontként szolgáló állami szerepvállalási mérték adja a klasszifikáció alapját. Szlovákia azért szerepel nálam az első csoportban, mert - noha a 2000-es évtizedben valóban a balti modellnek megfelelő alacsony újraelosztás felé mozdult el - az utóbbi években ezzel ellentétes tendencia figyelhető meg, és a közkiadások GDP-aránya újra 40 százalék felé kúszott, egyértelmúen a cseh, lengyel szinthez vált hasonlóvá. Hasonló a helyzet Horvátországgal kapcsolatban is, a horvát jövedelem-újraelosztási ráta a teljes vizsgált időszakban a 45-49 százalékos sávban mozgott, nem sokkal elmaradva a magyar és szlovén értéktől. ${ }^{66}$

A 3. ábra a térségbeli országok reál GDP-jének alakulását mutatja az ENSZ nemzetiszámla-adatbázisa (UNSTATS, 2016) alapján. Az 1990-hez viszonyított relatív teljesítményben lényeges eltérések mutatkoznak: Horvátország vagy Lettország 2014-es GDP-je alig haladja meg az 1990-es értéket, míg Lengyelország esetében több mint kétszeresre nőtt a gazdaság kibocsátása a negyedszázaddal ezelőttihez képest. A különbségek mellett is kirajzolódik azonban egy közös jellegzetesség, miszerint a kelet-közép-európai országok fejlődési pályája három, jól elhatárolható szakaszra osztható:

(1) a transzformációs visszaesés szakasza;

(2) az ezt követő erőteljes növekedési, felzárkózási periódus;

(3) a pénzügyi válságot követő gazdasági visszaesés és növekedési ütemvesztés. Az alábbiakban ennek a három szakasznak a jellegzetességeit tárgyalom.

${ }^{66} \mathrm{Az}$ ehhez kapcsolódó részletes adatokat lásd az 5.4. alfejezetben. 


\subsection{A transzformációs visszaesés időszaka}

A 3. ábra adatai alapján látható, hogy az 1989-1991-es rendszerváltozást mindenhol jelentős mértékủ recesszió, transzformációs visszaesés (Kornai, 1993) követte. Ennek teljes mérete nem is rajzolódik ki az ábrán, hiszen a gazdasági teljesítmény általában 1990-et megelőzően érte el a rendszerváltozás előtti csúcsot, az országok többségére - újonnan születő államokról lévén szó - azonban csak 1990-től állnak rendelkezésre a GDP adatok. A nem újonnan létrejött országok közül a teljes visszaesés mértéke Lengyelországban 1989-1991 között 17,8 százalék, Magyarországon 1989-1993 között 18,1 százalék, Bulgáriában 1988-1993 között 26,5 százalék, Romániában 1987-1992 között 29,7 százalék volt. (UNSTATS, 2016)

A legnagyobb mértékü visszaesés a balti államokat és Horvátországot sújtotta. Utóbbi esetében az 1991-1995 közötti véres függetlenségi háború is visszavetette a gazdaság teljesítményét, míg a balti államok esetében az elsődleges magyarázat az, hogy ezek az országok sokkal inkább integrálódtak a szovjet gazdaságba, mint a kelet-közép-európai szatelit-államok, így az ebből való kiszakadás, a vele együtt járó intézményi átalakulással, szerkezetváltással és piacvesztéssel lényegesen nagyobb költséggel járt. Ahogy Csaba (2007, p. 765) fogalmaz: „,e területek az egységes szovjet népgazdasági tér keretében fejlődtek, a moszkvai tervezőasztalokon kiötlött elképzelések szerint, kizárólag az összbirodalmi megfontolásokat követve. [...] a nagytérgazdaságból való kiszakadás értelemszerüen hatalmas áldozatokkal járt. Méghozzá lényegesen nagyobbakkal, mint a külső birodalom - a KGST - keretében működött közép-európai államok esetében. Hisz az utóbbiak - az ötvenes évek kivételével - megőrizték, és fokozatosan visszaszerezték viszonylagos önállóságukat.”

A térséget sújtó visszaesés nemzetközi összevetésben is kiemelkedö. Campos és Coricelli (2013) tanulmányukban Cerra és Saxena (2008) adatait felhasználva helyezik perspektívába a posztszocialista országok esetét. A mintában szereplő 637 recesszió átlagosan összesen 7,5 százalékos GDP-veszteséget jelentett, illetve átlagosan 1,62 év telt el a recessziót megelőző csúcstól a gazdasági teljesítmény mélypont-

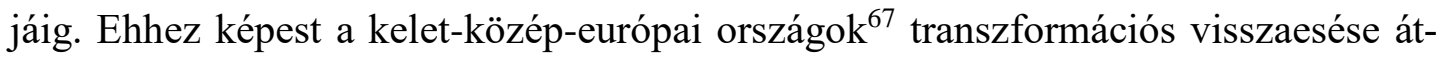
lagosan 19,3 százalékos GDP-csökkenést jelentett és 2,88 évig tartott. A volt Szovjetunió (baltiakon kívüli) országait még ennél is sokkal súlyosabban érintette a tranzíció: a GDP átlagosan 35,6 százalékot zuhant, és a visszaesés időtartama átlago-

${ }^{67}$ Campos és Coricelli (2013) tanulmányában ez nem pontosan azt a tizenegy országot jelenti, akiket én vizsgálok. 
san 4,56 év volt. Összehasonlításképpen a polgárháborúk által kiváltott recessziók esetében az átlagértékek 17,4 százalék és 2,42 év. (i.m., p. 424)

Noha az átalakulás konkrét menete egyedi jellemvonásokkal bír, mégis sok tekintetben felfedezhető egy általános minta. Turley (2013) az alábbi általános trendeket azonosította a posztszocialista tranzíción átesett országok tapasztalatai alapján:

(1) a kibocsátás először visszaesik, majd újra növekedésnek indul;

(2) az infláció először szárnyal, majd mérséklődik;

(3) a GDP szektorális összetételében jelentős változások zajlanak le, a szolgáltatások szerepe nagymértékben növekszik;

(4) a magánszektor súlya emelkedik a GDP előállításában;

(5) a beruházás és a fogyasztás is visszaesik, majd újra növekedésnek indul;

(6) a külkereskedelem visszaesés után emelkedik, az FDI beáramlás élénkül;

(7) az aktivitási és foglalkoztatási ráta visszaesés után emelkedik, a munkanélküliség felszökik;

(8) a kormányzati jövedelem-centralizáció és jövedelem-újraelosztás aránya mérséklődik;

(9) a demográfiai folyamatok romlanak, majd stabilizálódnak;

(10) az intézmények összeomlanak, majd újjáépülnek. (i.m., p. 18)

Kornai (1993) a transzformációs recesszió számos jellegzetességét leírja. Egyrészt nagyon erőteljesen érvényesült a schumpeteri „,teremtő rombolás” jelenségének egy sajátos formája. ${ }^{68} \mathrm{Az}$ árak és a külkereskedelem liberalizációja következtében a korábban elfojtott kereslet, illetve a piaci viszonyok érdemben el tudták kezdeni éreztetni hatásukat, aminek köszönhetően jelentős mértékben megváltoztak a relatív árak. Ez bizonyos területeken (például elektronika, híradástechnika, szolgáltatások) kifejezetten a kereslet - és ennek következtében a kibocsátás - növekedését jelentette, míg más ágazatokban nagymértékű visszaesést eredményezett. Vagyis nem egy általános visszaesésről volt szó, hanem alapvetően egy nagyon erőteljes gazdasági átrendeződésről. Az aggregált kibocsátás csökkenése pedig jelentős részben abból fakadt, hogy a negatívan érintett ágazatok, vállalatok visszaesése, bukása lényegesen gyorsabban ment végbe, mint a születő, illetve feltörekvő szektorok felemelkedése. Ez részben természetes jelenség (egy vállalat elindítása és főleg felfutta-

${ }^{68}$ Antal (2004, p. 113) véleménye szerint a tranzíciós válság ,nem írható le a schumpeteri alkotó rombolás kategóriájával”, azonban én úgy gondolom, hogy megfigyelhetők hasonlóságok a két eset között, még ha itt természetesen nem is egy innovációs hullám, hanem az intézményi környezet megváltozása indította el a gazdaság átstrukturálódását. 
tása időigényesebb, mint a bezárása), részben viszont a rendszerváltozás folyamata is ráerösített azáltal, hogy a korábbi állami vállalatok privatizációjával, a pénzügyi szektor hitelezési gyakorlatának változásával, a csődtörvény elfogadásával lényegesen keményebbé vált a vállalatok költségvetési korlátja, ami felgyorsította az életképtelen vállalatok bukását. Ez az ágazati, a tulajdonviszonyokat és vállalatméretet is érintő átalakulás, illetve az ebben megnyilvánuló időbeli diszkrepancia a nagymértékü visszaesés egyik fő oka, noha számos, egymással is összefüggő magyarázó tényezőre vezethető vissza az egész jelenség.

Egy másik fontos elem a koordinációs mechanizmusok között kialakuló „vákuum”. A bürokratikus koordináció intézményeinek összeomlása gyorsan ment végbe, míg a piaci koordináció intézményeinek kialakulása lényegesen időigényesebb folyamat. Ez jelenti a formális intézményeket (tervhivatal helyett tőzsde), a jogi kereteket, illetve az informális (beszállítói, értékesítési stb.) kapcsolatokat egyaránt. Ez az intézményi probléma szerves velejárója a tervgazdaságból a piacgazdaságba való átmenetnek, és a tranzíció folyamán visszaveti a vállalatok jövedelemtermelö képességét. Mindez főleg azért érdekes, mert ha abból indulunk ki, hogy a szocialista intézményrendszer hátráltatja a gazdasági teljesítményt (lásd például Kornai, 2011, 2.8. alfejezetben idézett gondolatmenetét az innovációval kapcsolatban), akkor abból az következne, hogy ezeknek a „rossz” intézményeknek, korlátoknak a lebontása önmagában is a hatékonyság javulását, azon keresztül a gazdasági növekedés serkentését kellene, hogy eredményezze. Ez a hatás azonban csak hosszabb távon érvényesül, a hatékonyság növekedéséhez nem elég a régi intézmények lebontása, az újak kiépülése is szükséges.

Harmadikként azt a közvetett hatást említhetjük meg, ami minden recesszió velejárója: a kibocsátás (a fenti okokkal magyarázható) visszaeséséböl, a növekvö munkanélküliségböl további kereslet-csökkenés következik. Ennek súlyát növeli a keresletvezérelt gazdaság kialakulása, vagyis az átmenet az „eladók piacáról” a „vevők piacára". Kornai (1993) ezt az adatokkal is dokumentált változást említi első helyen, hiszen rendszerszinten valóban nagyon fontos jelenségröl van szó, azonban önmagában ez az átmenet nem indokolja a kereslet (és így azon keresztül a gazdasági teljesítmény) visszaesését. Természetesen voltak az aggregált kereslet csökkenésének olyan „,autonóm” elemei (a külkereskedelmi piacok összeomlása, a beruházások viszszaesése a rendszerváltozással együtt járó bizonytalanság hatására), amelyekre jelentősen ráerősített a piaci struktúrának ez a fajta megváltozása. 
A transzformációs válság egyfelől jellegzetes, más recesszióktól érdemben különböző jelenség, ami számos közös jellemvonással bírt az érintett országokban, az azonban látható, hogy alakja és lefutása sem teljesen egységes a térség országai között. Ez részben a kiinduló állapot, a szocializmusból örökölt helyzet különbségeinek köszönhető, azonban értelemszerüen a választott gazdaságpolitikai megoldások is jelentős hatással bírtak. A tranzíció után követett eltérő utakat de Menil (2003) Lengyelország és Románia példáján illusztrálja. Lengyelországban Tadeusz Mazowiecki miniszterelnök és Leszek Balcerowicz pénzügyminiszter gazdaságpolitikájának középpontjában a mielőbbi liberalizálás és piacnyitás állt, ami egyfelől hirtelen megrázkódtatást jelentett a gazdaság számára, másfelől azonban segítette, hogy mielőbb kialakuljon a müködőképes piacgazdaság, illetve ennek megfelelően igazodjanak a gazdasági szereplők várakozásai. Romániában ezzel szemben igyekeztek tompítani a fogyasztás visszaesését, és elodázni az átalakulás sikeréhez szükséges, ámde népszerütlen intézkedéseket. Ennek egyik konkrét példája az árliberalizáció. Lengyelországban nagyon hamar liberalizálták az árak döntő többségét, aminek eredménye 1990-ben hatalmas mértékü (évi több mint 500 százalékos) infláció volt, amely azonban ezt követően folyamatosan mérséklődött. Ezzel szemben Romániában 1992ig a fogyasztóiár-indexhez használt kosár több mint felét, majd 1996-ig harmadát hatósági áras termékek adták, vagyis az árak piacosítása lényegesen lassabban ment végbe. Ennek megfelelően az infláció sem a lengyelhez hasonló lecsengő pályát követett, hanem az 1990-es évek folyamán többször hullámszerüen megugrott. Egy másik kiemelendő eltérés a vállalatok adósságainak kezelésében mutatkozik. Lengyelországban gyors ütemben visszavágták az állami vállalatok költségvetési támogatását, azonban ezt először még kiváltották az állami tulajdonú bankoktól érkező, gyorsan nem teljesítővé váló hitelek. Az 1990-es évek első felében különböző intézkedésekkel fokozatosan igyekezték keményíteni a vállalatok költségvetési korlátját, ebbe illeszkedett be az állami tulajdonú bankok privatizációja is, akik így nem finanszírozták tovább a vállalatok veszteségét. Romániában ezzel szemben 1990 novemberében eltörölték a vállalatok összes, az állam vagy a bankok felé fennálló adósságát. „Nehéz lenne elképzelni olyan intézkedést, ami jobban aláásná a költségvetési fegyelmet." (i.m., 2003, p. 286)

Az országok közötti különbségek tisztán megmutatkoznak abban, hogy Lengyelországban már 1992-ben növekedésnek indult a gazdaság, míg Romániában elhúzódott a tranzíciós válság: az 1993-ban meginduló növekedést az elodázott, de 
szükségessé vált intézkedések miatt 1996-ban újabb visszaesés követte, és csak az évezred legvégén kezdődött el a tartós gazdasági fellendülés.

\subsection{Közeledés Nyugat-Európához}

Bulgária és Románia kivételével a vizsgált országok az 1990-es évtized közepére maguk mögött hagyták az átalakulással járó gazdasági visszaesést, és megindult a 2007-2008-as pénzügyi és gazdasági válságig tartó, gyakorlatilag folyamatos fellendülés a térségben. Bár 1998-1999-ben néhány országban megtorpant a növekedés, átlagosan ezzel együtt is 3-7 százalékpontos éves GDP-bővülési ütemet produkáltak mintegy másfél évtizeden keresztül. Az erre az időszakra vonatkozó legfontosabb adatokat a 2. táblázat tartalmazza.

2. táblázat: A transzformációs válságot követő gazdasági fellendülés jellemzői a kelet-közép-európai országokban

\begin{tabular}{|c|c|c|c|c|}
\hline Ország & $\begin{array}{c}\text { A tartós gaz- } \\
\text { dasági növe- } \\
\text { kedés beindu- } \\
\text { lása }\end{array}$ & $\begin{array}{c}\text { A tartós gaz- } \\
\text { dasági növe- } \\
\text { kedés hossza }\end{array}$ & $\begin{array}{c}\text { Kumulált gaz- } \\
\text { dasági növe- } \\
\text { kedés mértéke }\end{array}$ & $\begin{array}{c}\text { Átlagos éves } \\
\text { gazdasági nö- } \\
\text { vekedési ütem }\end{array}$ \\
\hline Bulgária & 2000 & 9 év & $69,2 \%$ & $6,02 \%$ \\
\hline Csehország & 1993 & 16 év & $67,8 \%$ & $3,29 \%$ \\
\hline Észtország & 1995 & 13 év & $134,5 \%$ & $6,78 \%$ \\
\hline Horvátország & 1994 & 15 év & $87,3 \%$ & $4,27 \%$ \\
\hline Lengyelország & 1992 & 23 év ${ }^{* *}$ & $153,3 \%$ & $4,12 \%$ \\
\hline Lettország & 1996 & 12 év & $134,6 \%$ & $7,36 \%$ \\
\hline Litvánia & 1995 & 14 év & $129,3 \%$ & $6,11 \%$ \\
\hline Magyarország & 1994 & 15 év & $57,2 \%$ & $3,06 \%$ \\
\hline Románia & $2000 * * *$ & 9 év & $69,7 \%$ & $6,05 \%$ \\
\hline Szlovákia & 1993 & 16 év & $120,7 \%$ & $5,07 \%$ \\
\hline Szlovénia & 1993 & 16 év & $93,5 \%$ & $4,21 \%$ \\
\hline
\end{tabular}

Saját számítások az UNSTATS (2016) adatai alapján

Megjegyzés: *Az 1990-es évek végén több országban is megtorpant a növekedés. Csehországban 1997-98-ban, Észtországban, Horvátországban, Litvániában és Szlovákiában 1999-ben mérséklődött a gazdasági teljesítmény. Mivel azonban ezek a visszaesések átmenetiek (általában egy év) és mérsékeltek (legfeljebb 1 százalék) voltak, ezért nem tekintem őket a növekedési pálya megszakításának. ** Lengyelországban 1992-től kezdődően folyamatosan növekszik a reál GDP, a táblázatban azért szerepel 23 év, mert az UNSTATS (2016) adatsora jelenleg 2014-gyel végződik. ${ }^{* * *}$ Romániában a transzformációs válság mélypontja 1992-ben volt, azonban 1996-1999 között több mint 7 százalékkal esett vissza a GDP, így a tartós növekedés csak 2000-ben kezdődött meg.

Az adatokból látható, hogy a legtartósabb növekedést Lengyelország produkálta, 1992 óta minden évben emelkedett a reál GDP. Ennek köszönhetően a gazdaság kibocsátása 23 év alatt több mint két és félszeresére bővült, ami átlagosan évi 
4,12 százalékos növekedési ütemnek felel meg. A többi országot tekintve jól láthatóan kiemelkedik a balti államok teljesítménye. Miután rendkívül súlyosan érintette őket a transzformációs visszaesés, 1995-1996-ot követően huzamosan évi 6-7 százalékkal emelkedett a reál GDP-jük. Ennek eredményeként Észtországban 2002-ben, Litvániában 2005-ben, Lettországban 2006-ban sikerült meghaladniuk az 1990-es jövedelmi szintet, majd 2007-re elérni Észtországban annak 157, Lettországban 116, Litvániában pedig 125 százalékát. (UNSTATS, 2016)

Az elhúzódó recessziót követően késéssel meginduló bolgár és román növekedés is figyelemre méltó, 9 év alatt összesen közel 70 százalékkal emelkedett a GDP a két országban. A szlovák adatok az évezred végén a gazdasági növekedés megtorpanását jelzik, majd az ország a 2000-es években átlagosan 6,2 százalékos (2007-ben 10,8 százalékos) növekedési ütemet ért el - jelentős részben a Dzurindakormányzat gazdaságpolitikai intézkedéseinek is köszönhetően. Magyarországon bővült leglassabb, átlagosan évi 3 százalékos ütemben a GDP, ehhez az is hozzájárult, hogy hazánkban a gazdasági növekedés már 2006-ban megakadt - a pénzügyi válság jelentette külső sokktól függetlenül. (UNSTATS, 2016) Magyarország az egyetlen a vizsgált országok közül, amely 2000 és 2010 között lassabb növekedést produkált annál, mint ami a kezdeti egy főre jutó GDP-szintje alapján várható felzárkózási sebesség lett volna. ${ }^{69}$ (Marer, 2013, p. 245)

Összességében ezzel együtt is a régió egésze nagyon jelentős felemelkedésen ment keresztül ebben az időszakban. Ez természetesen érdemi mértékü felzárkózást is jelentett Nyugat-Európa fejlettebb országaihoz viszonyítva. Erről tanúskodnak a 3. táblázat adatai is: 2000-et megelőzően és 2008-at követően ugyan vegyes a kép, de 2000-2008 között minden térségbeli ország lényegesen közelebb jutott az EU-15 országok átlagos fejlettségi szintjéhez.

1995-ben Csehország és Szlovénia az EU-15 átlag 63-65 százalékán állt, míg a többi térségbeli ország ehhez képest lényegesen alacsonyabb, 27-43 százalékos relatív fejlettségi szintről indult. 2015-re Csehország 80, Szlovénia 76 százalékig kapaszkodott, de Bulgária, Horvátország és Románia kivételével a többi kelet-középeurópai ország is elérte az EU-15 átlagának 59-71 százalékát. Érdemes megjegyezni, hogy az adatok Magyarország fokozatos pozícióvesztéséröl is tanúskodnak. 1995-ben

${ }^{69}$ Oblath (2014b, pp. 32-33) az 1993-2013 közötti időszakot vizsgálva jutott hasonló következtetésre: az Európai Unióhoz 2004-ben csatlakozott volt szocialista országok közül csak Magyarország növekedett lassabban, mint amekkora felzárkózási lehetőség adódott volna az alacsonyabb kiinduló jövedelmi helyzetből az EU-n belüli reálkonvergencia folyamatai alapján. 
és 2000-ben hazánk még harmadik helyen állt a térségbeli országok rangsorában, 2008-ban már a hatodik, 2015-ben a hetedik pozíció a mienk. Erről a lemaradásról, a Nyugat-Európához való konvergencia 2000-es években megfigyelhető elakadásáról Oblath (2014b) tájékoztat részletesen a magyar teljesítményt a többi visegrádi országgal összevetve.

\section{3. táblázat: A kelet-közép-európai országok egy fôre jutó GDP-je az EU-15 átlagának százalékában (folyó vásárlóerō-paritáson)}

\begin{tabular}{|c|c|c|c|c|}
\hline Ország & 1995 & 2000 & 2008 & 2015 \\
\hline Bulgária & $29,0 \%$ & $24,1 \%$ & $40,6 \%$ & $42,6 \%$ \\
\hline Csehország & $65,3 \%$ & $61,8 \%$ & $73,3 \%$ & $80,1 \%$ \\
\hline Észtország & $30,1 \%$ & $36,8 \%$ & $61,1 \%$ & $68,6 \%$ \\
\hline Horvátország & --- & $42,1 \%$ & $56,9 \%$ & $53,5 \%$ \\
\hline Lengyelország & $36,4 \%$ & $40,4 \%$ & $49,3 \%$ & $63,1 \%$ \\
\hline Lettország & $28,4 \%$ & $31,1 \%$ & $53,8 \%$ & $59,3 \%$ \\
\hline Litvánia & $29,5 \%$ & $33,3 \%$ & $56,3 \%$ & $67,6 \%$ \\
\hline Magyarország & $43,2 \%$ & $46,1 \%$ & $56,6 \%$ & $62,5 \%$ \\
\hline Románia & $27,3 \%$ & $21,9 \%$ & $43,4 \%$ & $52,2 \%$ \\
\hline Szlovákia & $40,3 \%$ & $42,5 \%$ & $64,2 \%$ & $70,5 \%$ \\
\hline Szlovénia & $63,1 \%$ & $68,0 \%$ & $80,2 \%$ & $76,0 \%$ \\
\hline
\end{tabular}

Saját számítások az Eurostat (2016) adatai alapján

A 3. táblázatban szereplő különböző időszaki adatok közvetlenül nem hasonlíthatók össze egymással, hiszen a folyó vásárlóerö-paritáson mért relatív GDP növekedése nem feltétlenül jelent reálkonvergenciát, azt a vásárlóerő-paritás időszakok közötti megváltozása is okozhatja. ${ }^{70}$ Erre a konstans vásárlóerö-paritással számolt idősorok alkalmasak.

A 4. ábrán kirajzolódnak a felzárkózási pályák hasonlóságai és különbözőségei. Az 1990-es évek végén még nem mutatkozott egységes felzárkózási trend, hiszen ebben az időszakban még több térségbeli országot is kisebb-nagyobb visszaesés sújtott. Ahogy korábban láttuk, Bulgáriában és Romániában 2000-ig alapvetően csökkenő trendet mutatott a kibocsátás, de az évezred végén rövidebb időre több más országban is megtorpant a transzformációs recesszió után meginduló növekedés. ${ }^{71}$ Magyarországon pedig az 1995-ös Bokros-csomag akasztotta meg a gazdasági növekedés pályáját. Lengyelország, Szlovénia és a három balti állam volt az, amelyik már

\footnotetext{
${ }^{70}$ E tekintetben lásd Oblath (2014b, pp. 24-25) fejtegetését.
}

${ }^{71}$ Lásd a 2. táblázathoz füzött megjegyzést. 
1995-2000 között is egyértelmü reálkonvergenciát tudott felmutatni a nyugateurópai országokhoz viszonyítva.

4. ábra: Egy fôre jutó GDP az EU-15 átlagának százalékában

(2010. évi árakon és vásárlóerố-paritáson számolva)

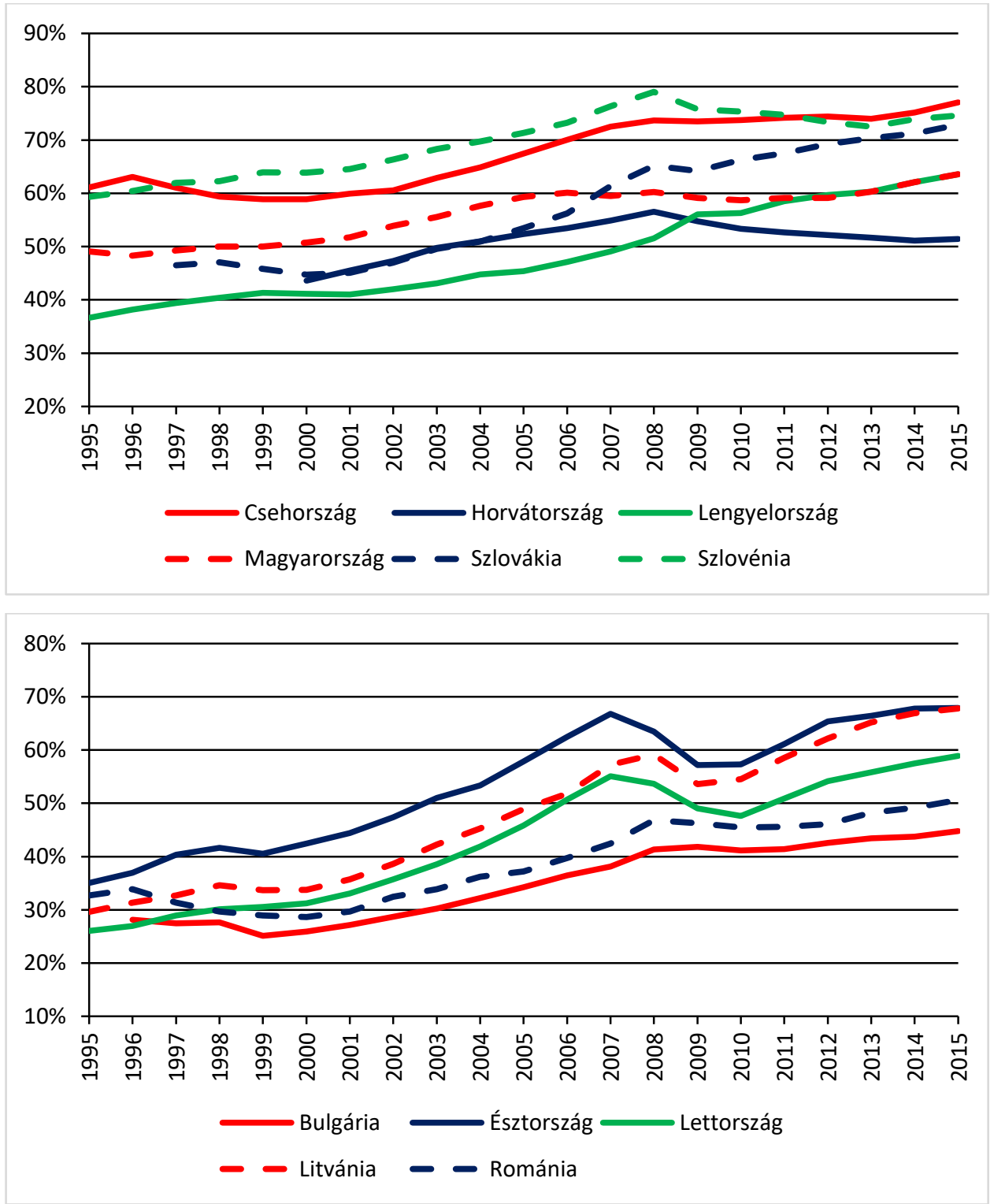

Saját szerkesztés az Eurostat (2016) adatai alapján

2000-től kezdődően azonban egészen 2007-2008-ig a teljes régióban kimutatható egy többnyire gyors ütemü felzárkózás. Ennek mértéke mindhárom balti országban, valamint Szlovákiában is meghaladta a 20 százalékpontot a kevesebb mint egy évtized alatt. Számunkra szomorú fejlemény, hogy ez a konvergencia Magyaror- 
szágon volt a leglassabb, ráadásul 2006-ban el is akadt, 2006-2013 között gyakorlatilag változatlan volt a Nyugat-Európához viszonyított relatív helyzetünk.

A 2008 utáni fejleményekre még visszatérünk, de az a 4. ábra adatai alapján jól látható, hogy a térségbeli országok különböző pályákat futottak be a konvergencia tekintetében az elmúlt években. Lengyelországban és Szlovákiában szinte töretlen a felzárkózás. A pénzügyi válság által legerősebben sújtott balti államokban az egy főre jutó, vásárlóerő-paritáson számolt GDP 2007-2008 és 2009-2010 között jelentősen, 6-10 százalékponttal visszaesett az EU-15 átlagához képest, majd ezt egy gyors „visszazárkózás” követte, aminek eredményeként mára mindhárom ország elérte és meghaladta a recesszió előtti relatív pozícióját. Bulgáriában, Csehországban, Magyarországon és Romániában a felzárkózás elakadását és lassulását figyelhetjük meg, míg Horvátországban és Szlovéniában kifejezetten leszakadást.

Érdemes egy megjegyzést füzni a felzárkózásról elmondottakhoz. Az egy főre jutó GDP az életszínvonal alakulásának csak egy szeletét fejezi ki. Itt nem is a GDP mint jövedelmi mutató korlátaira gondolok, hanem arra, hogy az életszínvonalat nem csak az adott időszaki kibocsátás és jövedelem, hanem a társadalom rendelkezésére álló vagyon (infrastruktúra, lakásállomány, kórházak és iskolák mennyisége és minősége stb.) is jelentősen befolyásolja - hasonlóan ahhoz, ahogy egy család életszínvonalát is meghatározza vagyoni helyzete is, nem csak a folyó jövedelme. ${ }^{72}$ Vagyis a GDP-ben mutatkozó reálkonvergenciára vonatkozó adatok nem jelentik azt, hogy a Nyugat-Európához viszonyított relatív életszínvonalban is ugyanekkora lett volna a felzárkózás.

Azt is fontos kiemelni, hogy a gazdasági növekedés, illetve reálkonvergencia adatai sokkal átfogóbb gazdasági változásokat tükröznek. Természetesen minden térségbeli országban dominánssá vált a magánszektor szerepe, és az ágazati struktúrában is nagy eltolódások következtek be. Turley (2013, pp. 21-22) adatai szerint 1989-1990 és 2008 között átlagosan 46 százalékról 30 százalékra csökkent az ipari szektor GDP-n belüli aránya a kelet-közép-európai országokban, míg a szolgáltatások súlya 39 százalékról 64 százalékra emelkedett.

A felzárkózási időszak jellemzését a demográfiai és munkaerő-piaci folyamatok bemutatásával kezdjük, majd rátérünk a régió országaiban alkalmazott gazdasági modell kulcselemeire: a tőkefelhalmozásra és gazdasági nyitottságra.

\footnotetext{
${ }^{72}$ Lásd Kornai (1972, pp. 34-37) gondolatmenetét.
} 


\subsection{Demográfiai és munkaerő-piaci folyamatok}

A demográfiai folyamatok tekintetében sajátos kettősség jellemzi az európai országokat. A 28 tagú Európai Unió népessége 1990 és 2015 között 7 százalékkal, mintegy 33 millió fővel emelkedett. Ez azonban messze nem egységesen igaz a tagállamokra. Míg Nyugat-Európa minden országának növekedett a népessége ez idő alatt (az EU tagállamok mellett igaz ez Svájcra, Izlandra és Norvégiára is), addig a keleti tagállamok között elvétve találunk ilyet. (Eurostat, 2016) Ez a kettősség a természetes népszaporulat és a migráció eredőjeként alakult ki. Egyfelől Nyugat-Európát magasabb várható élettartam és jobb halálozási mutatók jellemzik (a transzformációs válság során egyes volt szocialista országokban átmenetileg kifejezetten romlottak is a halálozási adatok). Másfelől az EU-n belül is megfigyelhető egy kelet-nyugat irányú népmozgás, illetve az EU-n kívülről érkezők célországai is a kontinens nyugati, fejlettebb államai. ${ }^{73}$

A kelet-közép-európai országok népességváltozását mutatja az 5. ábra. Látható, hogy mindössze három országban (Szlovénia, Szlovákia és Csehország) emelkedett a népességszám, míg Lengyelországban gyakorlatilag ugyanakkora 2015-ben, mint volt 1990-ben. Természetesen ez sem jelent állandó népességszámot, 1999-ig növekvő, míg azóta csökkenő trendet mutat a lengyel népesség. Csehországban és Szlovéniában ezzel ellentétes volt a demográfiai változás iránya: a 2000-es évek elején állt növekvő pályára a lakosságszám, míg Szlovákiában egy kisebb visszaesést leszámítva gyakorlatilag folyamatos a növekedés.

A térség többi országában gyakorlatilag folyamatos népességszámcsökkenésnek lehetünk tanúi. A legsúlyosabb demográfiai helyzet a balti államokat sújtja: a népességük 17-27 százalékkal esett vissza a vizsgált időszakban. Emellett Bulgária és Románia népessége is 18, illetve 12 százalékkal csökkent. Ez a nagymértékü népességfogyás jelentős részben a nyugati irányú migráció következménye is, ami azért is probléma, mert a fiatal, képzett, vállalkozó kedvü és kezdeményezőképességgel rendelkező munkaerő kivándorlása komolyan visszavetheti a gazdaság jövőbeli teljesítőképességét.

${ }^{73}$ Az Eurostat (2016) adatbázisában rendelkezésre álló adatokból egyértelműen ez a kép rajzolódik ki: 2015-ben Magyarországon 1,48 százalék, Szlovákiában 1,14 százalék, Lengyelországban 0,28 százalék volt a külföldi állampolgárok aránya, míg Németországban, Olaszországban, Spanyolországban és az Egyesült Királyságban 8-10 százalék, Belgiumban és Írországban több mint 11 százalék, Ausztriában 13 százalék, Svájcban pedig több mint 24 százalék. (A balti államok eltérő képet mutatnak Észtországban és Lettországban is 15 százalék körüli a külföldi állampolgárok aránya - ezt azonban a nagyszámú orosz kisebbség magyarázza, akiknek jelentős része nem észt, illetve lett, hanem orosz állampolgársággal rendelkezik.) 


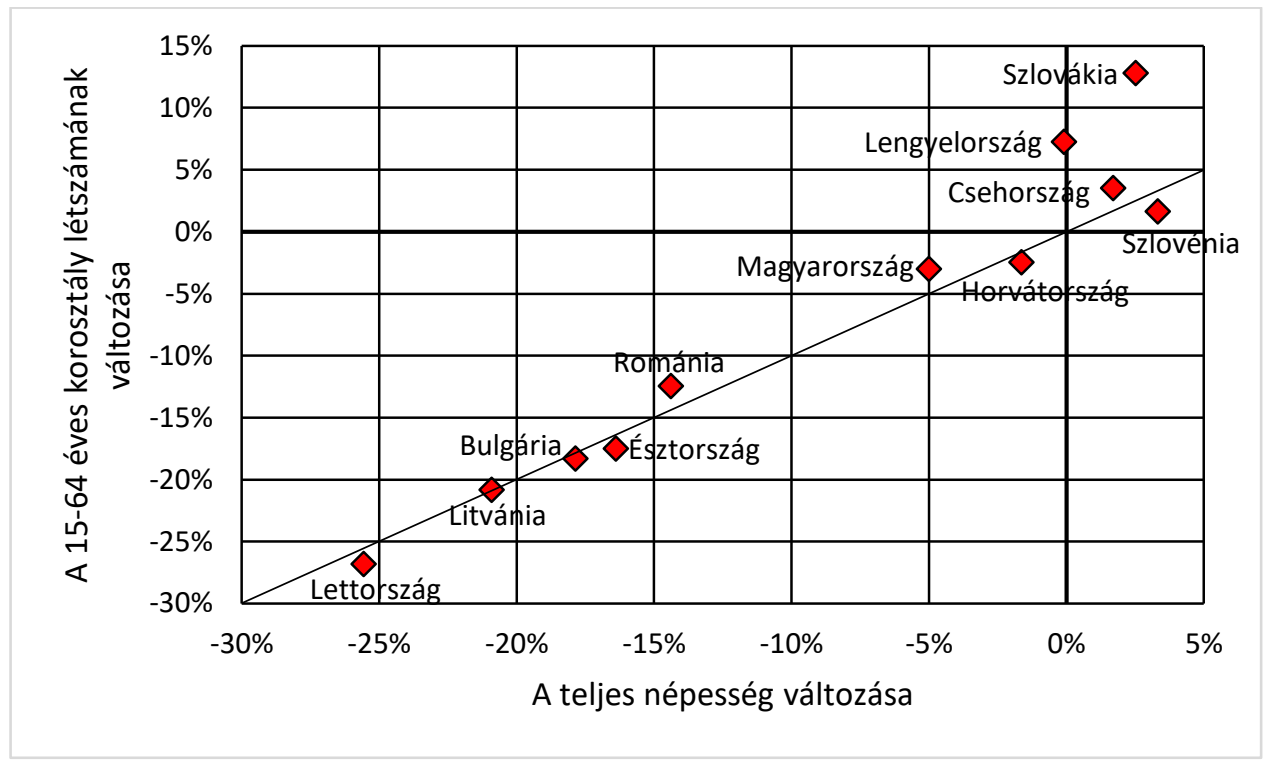

Saját szerkesztés az Eurostat (2016) adatai alapján

Megjegyzés: Mivel a korosztályi bontás Horvátországra csak 2001-től érhető el az Eurostat (2016) adatbázisában, ezért az ábrán szereplő horvát adatok a 2001-2015 közötti időszakra vonatkoznak. A teljes népesség 1990 és 2015 között összesen 11,47 százalékkal csökkent.

Ennek a demográfiai folyamatnak kétféle olvasata van a gazdasági növekedés és felzárkózás szempontjából. Az egyik az, hogy az 1990-esnél lényegesen magasabb GDP-t a térségbeli országok többségében kisebb számú népesség állítja elő. A baltiaknál ez különösen erőteljesen jelentkezik, főleg ha a transzformációs válság mélypontjához viszonyítunk: ezek az országok úgy növelték több mint duplájára a kibocsátásukat, hogy népességük akár több mint ötödével csökkent. Ez azt mutatja, hogy a gazdaság annál is nagyobb hatékonyságnövekedésen ment keresztül, mint amit maguk a GDP-idősorok mutatnak.

Ugyanennek a jelenségnek a másik oldala viszont az, hogy a NyugatEurópához viszonyított, egy főre jutó GDP-ben mutatkozó felzárkózás, közeledés részben pusztán a népesség (vagyis a nevező) csökkenésének tudható be. Önmagában a népességfogyás viszont aligha tekinthető gazdasági fejlődésnek.

A jövedelemtermelés szempontjából nem a teljes lakosságszám alakulása az elsődleges fontosságú, hanem a munkaképes korú népesség változása. Ahogy az 5. ábrán látható, a legtöbb országban gyakorlatilag azonos ütemben változott a két csoport létszáma, ez alól csak Lengyelország és Szlovákia a kivétel, ahol jelentősen (5, illetve 6 és fél százalékponttal) megnőtt a 15-64 éves korosztály aránya. Ez persze 
nem jelenti azt, hogy a korosztályi arányok egyáltalán ne változtak volna a többi országban. Miközben a munkaképes korúak aránya az említett két kivétellel mindenhol valóban nagyjából azonos maradt, addig egy jelentős eltolódás figyelhető meg: csökkent a 15 éven aluliak és nőtt a 64 éven felüliek aránya. (Függelék F1. ábra) Ez természetesen szorosan összefügg a népességszám csökkenésével: a kisebb gyermekszám az egyik fő oka a népességfogyásnak. Ami a jelenség gazdaságpolitikai következményeit illeti: mindenhol jelentősen megnőtt az időskori függőségi ráta (idősek és munkaképes korúak egymáshoz viszonyított aránya), és ez egyre nagyobb nyugdíjterhet jelent a gazdaság számára. Ezt azonban kompenzálja a fiatalkori függöségi ráta (fiatalok és munkaképes korúak egymáshoz viszonyított aránya) jelentős csökkenése, így a teljes függőségi ráta mindenhol nagyjából változatlan, Lengyelországban és Szlovákiában pedig nagymértékben csökkent is: 54,4-ről 43,8 százalékra, illetve 55,6-ról 41,4 százalékra. (Eurostat, 2016) Ez persze csak a demográfiai oldala a kérdésnek, a potenciálisan eltartásra jogosultak és a potenciális eltartók viszonyát mutatja. A ténylegesen eltartottak és eltartók aránya (vagyis a gazdasági szempontból igazán releváns kérdés) emellett a szociálpolitikai rendszeren és a munkaerőpiac folyamatain múlik. Illetve azt is hozzá kell tenni, hogy természetesen a gazdaság szempontjából nem irreleváns a 15 év alattiak és 64 év felettiek egymáshoz viszonyított aránya akkor sem, ha mindkét csoport eltartottnak tekinthető.

A 6. ábrán a három fő munkaerő-piaci mutató 1997-2008 közötti átlagos értékei láthatók a kelet-közép-európai országokban. Az aktivitási ráta a munkaerőpiacon megjelenők (munkaerő-állomány), míg a foglalkoztatottsági ráta a foglalkoztatottak arányát mutatja a 15-64 éves korosztályban. A munkanélküliségi ráta pedig a munkanélküliek arányát adja meg a munkaerő-állományon belül. A három változó között egyértelmű összefüggés van: $a r \cdot u r+e r=a r$, ahol $a r$ az aktivitási, $u r$ a munkanélküliségi, er a foglalkoztatottsági arány. Természetesen jelentős változásokon mentek át a mutatók az időszak folyamán, az átlagok így is megragadnak tartós különbségeket az országok között.

A három balti állam, valamint Csehország, Szlovákia és Szlovénia is az EU15 átlagához hasonló aktivitási rátával rendelkezett a vizsgált időszakban. A munkaerö-kínálati oldal tehát hasonló képet mutat, a keresletben, és annak következtében a munkanélküliségben azonban nagy eltérések vannak. Csehországban és Szlovéniában átlagosan kisebb volt a munkanélküliség (és ezzel összefüggésben nagyobb a foglalkoztatottság), mint a nyugat-európai országokban. 


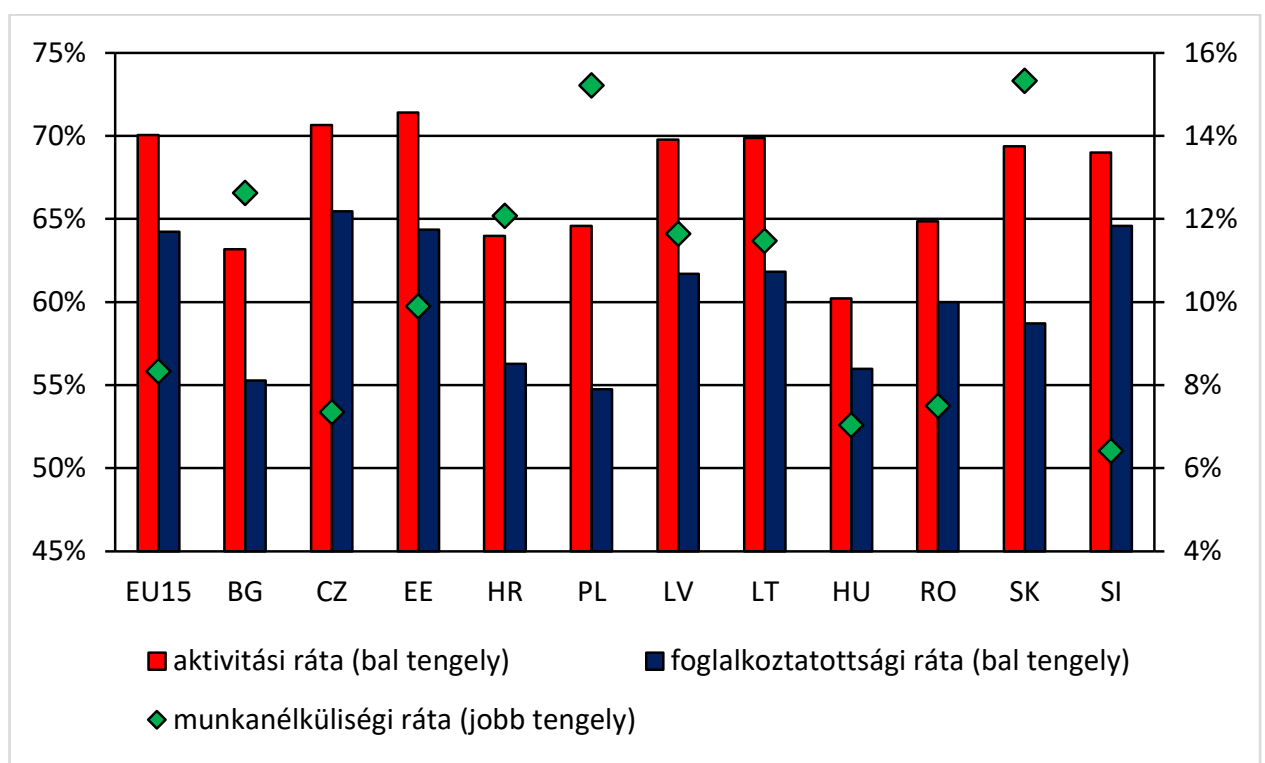

Saját szerkesztés az Eurostat (2016) adatai alapján

Megjegyzés: Az Eurostat (2016) adatbázisában Csehország, Lengyelország és Románia adatai 1998-tól, Bulgária adatai 2000-től, Horvátországéi pedig 2003-tól érhetők el, így az ábrán szereplő átlagos értékek ezen országok esetében ennek megfelelöen rövidebb időszakra vonatkoznak. Jelmagyarázat: BG: Bulgária, CZ: Csehország, EE: Észtország, HR: Horvátország, PL: Lengyelország, LV: Lettország, LT: Litvánia, HU: Magyarország, RO: Románia, SK: Szlovákia, SI: Szlovénia

A másik véglet e tekintetben Szlovákia. Északi szomszédunk az időszak egészét tekintve a legnagyobb munkanélküliséggel küszködött, a legsúlyosabb helyzet az 1999-2005 közötti éveket jellemezte, ekkor egy évben sem csökkent 16 százalék alá a munkanélküliség. Ez jelentős részben a már említett, jobbközép Dzurindakormányzat gazdaságpolitikai intézkedéseinek is köszönhető: a munkaerőpiacot liberalizáló intézkedések mellett a kormányzat gazdasági kiadásait (beleértve a vállalkozások támogatását) is jelentősen lefaragták: az Eurostat (2016) adatai szerint a GDP 11,2 százalékáról 4,0 százalékára esett vissza 2000 és 2005 között.

A régió másik öt országában végig szignifikánsan alacsonyabb volt a munkaerő-piaci részvétel aránya, a legalacsonyabb éppen Magyarországon. Hazánk esetében hozzá kell azonban tenni, hogy 2009 óta a munkaerő-kínálat ösztönzését célzó intézkedések (a támogatási rendszer átalakítása, beleértve az álláskeresési járadék folyósításának 9 hónapról 3 hónapra rövidítését) hatására több mint 7 százalékponttal növekedett az aktivitási ráta. Ugyanez a növekedés a foglalkoztatottságban is megfigyelhető (a 2010-es 54,9 százalékról 63,9 százalékra emelkedett), azonban ez csak 
részben köszönhető a magyar versenyszféra válság után újjáéledő foglalkoztatásnövekedésének, jelentős szerepe van benne a közfoglalkoztatásnak és a külföldön munkavállalók létszámának megugrásának.

A teljes foglalkoztatotti létszám demográfiai és munkaerő-piaci folyamatok eredőjeként alakul. (Függelék F2. ábra) A foglalkoztatottsági rátával (Függelék F3. ábra) együtt levonható néhány következtetés. A balti államokban, ahol a legnagyobb arányban csökkent a népesség, megkerülhetetlen a demográfia hatása. Ez jól látható abból, hogy a 2000-es években jelentősen emelkedő foglalkoztatottsági arány mellett is csak stagnált (Litvánia) vagy mérsékelten emelkedett (Észtország, Lettország) a foglalkoztatottak száma. 2008 után sokan elvesztették munkájukat, és azóta hiába érte el a foglalkoztatottsági ráta a pénzügyi válság előtti szintjét, a negatív demográfiai folyamatok eredményeként Lettországban és Litvániával több mint 10 százalékkal kevesebben dolgoznak ma, mint 1998-ban. A legjobb munkaerő-piaci mutatókkal rendelkező Észtországban is csak alig több foglalkoztatott volt 2015-ben, mint az időszak elején.

A válságot megelőzően minden térségbeli országban jellemző volt a foglalkoztatottsági ráta emelkedése (legnagyobb mértékben Bulgáriában és Lengyelországban). Bulgáriában ez a foglalkoztatotti létszám gyors ütemü növekedését is eredményezte a munkaképes korú lakosság számának csökkenése ellenére. A másik véglet Románia, ahol a népességcsökkenést stagnáló foglalkoztatottsági arány egészítette ki.

\subsection{Tökefelhalmozás és nyitottság}

Mint a 3. ábra és a 2. táblázat adatain láttuk, az egyes országok között nem csak a tranzíció lefolytatásában, hanem a későbbi növekedési pályában is vannak érdemi eltérések, azonban közös minta is fellelhető. Marer (2013) a kelet-közép-európai országok növekedési modelljének az alábbi jellemzőit emelte ki:

(1) a belsö kereslet gyors ütemü expanziója;

(2) ezt az expanziót a hitelállomány gyors bővülése tette lehetővé;

(3) a növekedést jelentős mértékben külföldi tőkebeáramlás finanszírozta;

(4) ez lehetővé tette a folyó fizetési mérleg tartósan deficites állapotát;

(5) a régió országai gyorsan integrálódtak a globális gazdaságba;

(6) a térség gazdaságaiban jelentős reálárfolyam-felértékelődés ment végbe. (i.m., p. 243) 
Ezekből a jellemzőkből az alábbiakban a tőkefelhalmozást és tőkebeáramlást, a folyó fizetési mérleg hiányát, valamint a globális gazdaságba való (kereskedelmi) integrálódást emelem ki.

7. ábra: Átlagos nettó beruházási ráta a kelet-közép-európai országokban

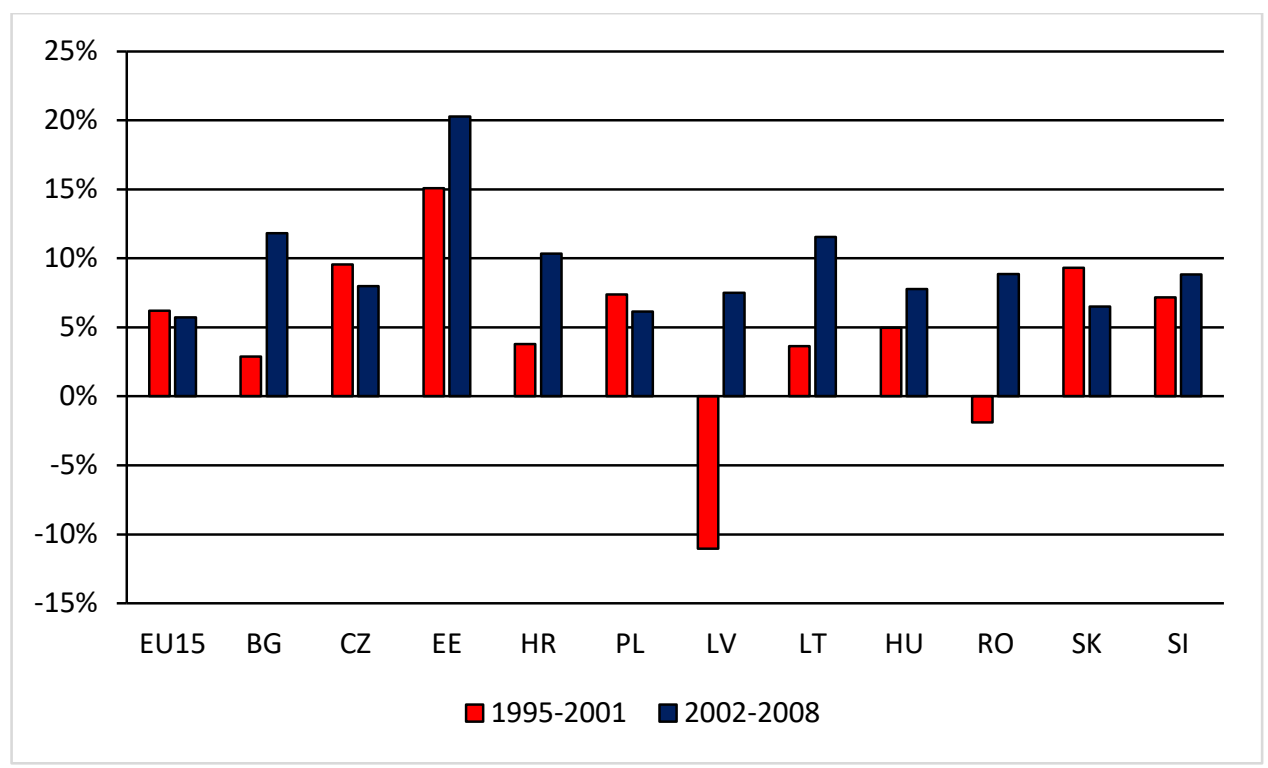

Saját szerkesztés az AMECO (2016) adatai alapján

Jelmagyarázat: BG: Bulgária, CZ: Csehország, EE: Észtország, HR: Horvátország, PL: Lengyelország, LV: Lettország, LT: Litvánia, HU: Magyarország, RO: Románia, SK: Szlovákia, SI: Szlovénia

A 3.5. alfejezetben idézett empirikus eredmények arról árulkodnak, hogy a hagyományos termelési tényezők közül a fizikai tőke felhalmozása állt a keletközép-európai országok növekedési modelljének középpontjában. ${ }^{74}$ Ez leolvasható a 7. ábráról is, mely az amortizáció pótlásán felüli nettó beruházási ráta (nettó állóeszköz-felhalmozás a GDP százalékában) átlagos értékeit mutatja a térség országaiban. A tőkefelhalmozás szempontjából ez a mutató lényegesebb a bruttó beruházási rátánál, hiszen az elhasználódó tőkejavak pótlása önmagában nem eredményezi a termelésbe vonható tőkeállomány bővülését.

Látható, hogy 1995-2001 között még csak Csehországban, Észtországban, Lengyelországban, Szlovákiában és Szlovéniában volt magasabb a nettó beruházási ráta, mint a nyugat-európai országokban, míg a másik véglet Lettország és Románia, ahol e hat év alatt - a szocializmus évtizedei alatt kiépített kapacitások gyors amorti-

\footnotetext{
${ }^{74}$ Kivétel ez alól a Kónya (2015) tanulmánya végén szereplő alternatív dekompozíció eredménye.
} 
zációja és leépülése eredményeként - csökkent a fizikai tőke állománya. 2001-től kezdődően azonban már mindenhol a tőkeállomány bővülése figyelhető meg, és az látható, hogy az összes térségbeli országban magasabb a nettó beruházások GDParánya, mint az EU-15 átlaga. A pénzügyi válságot közvetlenül megelőző években az országok többségében 10, Bulgáriában, Észtországban és Romániában 20 százalék fölé is kúszott a nettó beruházási ráta. ${ }^{75}$

Egy tőkeszegényebb gazdaságban természetesen a fejlettebb országoknál nagyobb beruházási aktivitásra van szükség a felzárkózáshoz, és ahogy a 4.3. alfejezetben láttuk, jelentős részben e gyorsabb tőkefelhalmozás révén a kelet-közép-európai országok egy főre jutó GDP-jének vásárlóereje ez időszak alatt lényegesen közelebb is került a nyugat-európai átlaghoz. Másik oldalról mindez a tőke csökkenő hozadékát feltételező Solow-modell predikcióival is összhangban van: a relatíve tőkeszegényebb országban magasabb a megtérülési ráta, ezért nagyobb a beruházások aránya, ami a tőkeellátottság növekedéséhez, és azon keresztül gazdasági felzárkózáshoz vezet.

Tartozik egy kiegészítő megjegyzés a beruházási rátákkal kapcsolatban elmondottakhoz. Ez a mutató önmagában nem árul el semmit arról, hogy a beruházásokon belül mekkora volt a (későbbi jövedelemtermelést szolgáló, de közvetlenül az életszínvonalat nem javító) termelő-beruházások és a (közvetlenül az emberek hasznosságát növelö) fogyasztói tőke felhalmozásának (például lakásberuházások vagy kórházépítés) aránya. Ezt azért tartom érdemesnek kiemelni, hogy - miként a 4.3. alfejezet végén is - felhívjam rá a figyelmet: a beruházások által hajtott GDPnövekedés és az annak eredményeként megfigyelhető reálkonvergencia üteme nem feleltethető meg egy az egyben az életszínvonalban is mutatkozó felzárkózás mértékének.

Egy fejlődő, kis, nyitott gazdaság számára a tőkeállomány felzárkózáshoz szükséges bővítése nem képzelhető el kizárólag hazai források felhasználásával. A térségbeli országokban is jelentős szerepet játszott a külföldi közvetlen tökeberuházás (foreign direct investment, FDI) ebben a folyamatban. A bejövő FDI (tulajdonképpen a külföldiek tulajdonában lévő vállalatok és eszközeik) szerepe a világgazdaságba való egyre erőteljesebb bekapcsolódással folyamatosan emelkedett a térség országai-

\footnotetext{
${ }^{75}$ A nettó beruházási ráta időbeli alakulása a Függelék F4. ábráján látható.
} 
ban. Ez látható a 8 . ábrán a néhány kisebb visszaeséstől eltekintve egyértelmüen növekvő trendet mutató GDP-arányokon.

8. ábra: A bejövő FDI állománya a GDP százalékában

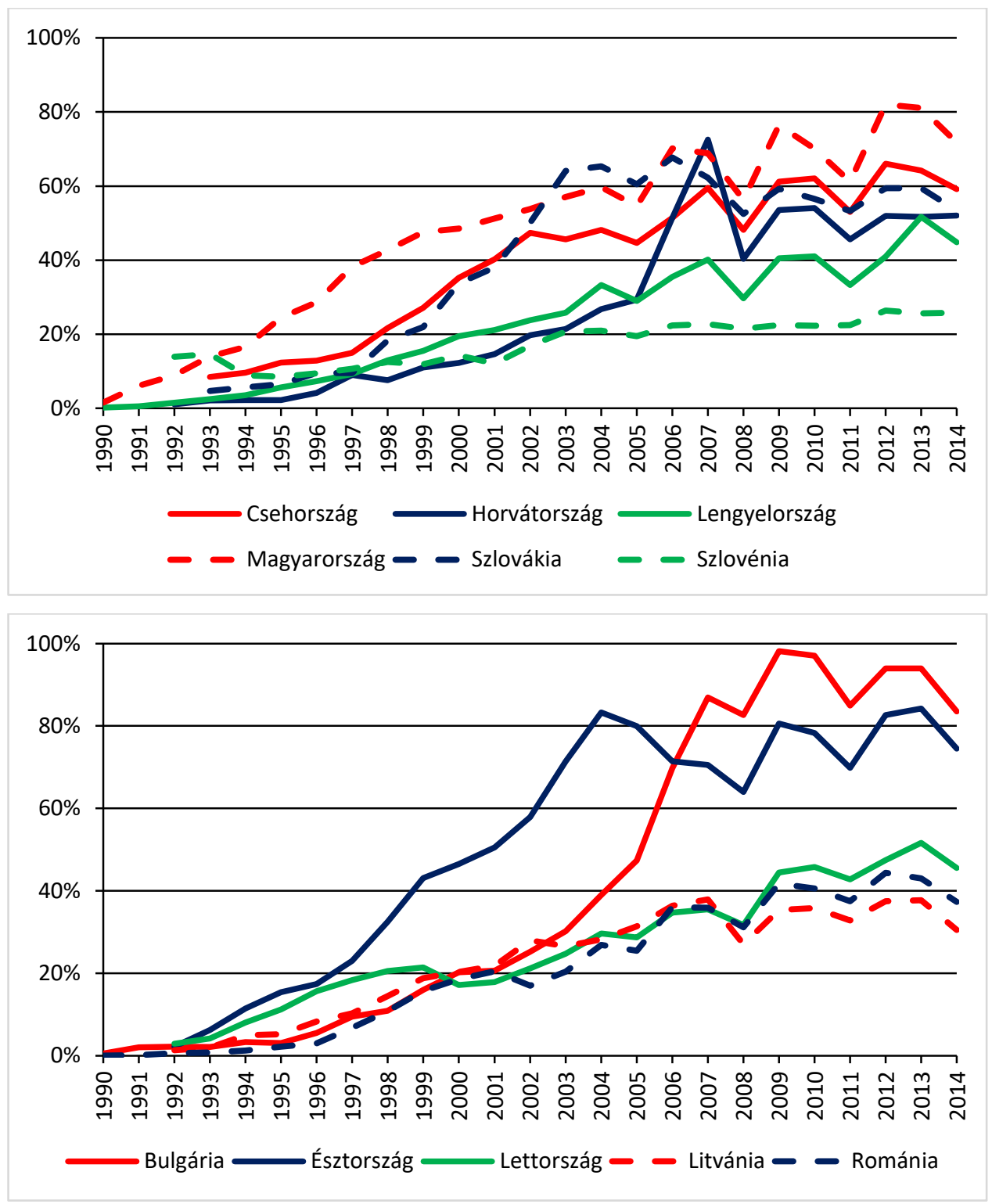

Saját szerkesztés az UNCTAD (2016) adatai alapján

A külföldi források bevonása mindegyik térségbeli országban szerepet kapott, azonban természetesen itt is megfigyelhetők különbségek. Ez egyfelől gazdaságpolitikai döntés kérdése is (adókedvezmények, vagy azon ágazatok támogatása, amelyekben a multinacionális vállalatok szerepe nagy - például autóipar), másfelöl a tőketulajdonosok telephely-választási döntésén is múlik. E tekintetben fontos szempont az adott ország munkaerejének képzettsége, fizikai infrastruktúrájának állapota, 
gazdaságpolitikai környezete, illetve kiszámíthatósága. A rendszerváltozást követően Magyarországon volt a leggyorsabb az FDI-beáramlás, majd Észtországban, illetve Szlovákiában gyorsult fel nagyon. A válságot közvetlenül megelőzően pedig Bulgáriában növekedett robbanásszerủen az FDI állományának értéke.

Az adott évi FDI-beáramlás egy före jutó értékeit megvizsgálva azt láthatjuk, hogy 1990-1997 között egy kivétellel minden évben Magyarországon volt a legmagasabb a működőtőke-beáramlás értéke, 1998-2004 között felváltva Észtországban, Csehországban és Szlovákiában, majd 2005 óta a legtöbb évben Észtországban. Az FDI állományának egy főre jutó értéke 1993 előtt Szlovéniában, 1994-2001 között Magyarországon, 2003 óta Észtországban a legmagasabb. (UNCTAD, 2016) Észtország e mutató tekintetében természetesen kis mérete miatt is kiemelkedik, de a külföldi tulajdonú müködő tőke szerepe mindenképpen megkérdőjelezhetetlen az ország gazdasági teljesítményében.

A Függelék F5. ábrája az adott évi FDI-beáramlást mutatja a bruttó beruházások százalékában. Ebből szintén kiolvasható a külső források jelentősége, hiszen a válságot megelőző időszakban minden térségbeli országban volt olyan év, hogy amikor ez az arány 25 százalék fölött volt. 2002-ben Szlovákiában meghaladta a 80 százalékot, 2007-ben Bulgáriában a 100 százalékot közelítette.

Az FDI-beáramlás által is megjelenített külső pénzügyi nyitottság „,másik oldalát" jelenti a folyó fizetési mérleg hiánya. (9. ábra) Tekintve a kelet-közép-európai országok tőkeellátottságának alacsony szintjét, ilyen tőkebeáramlásra mindenképpen szükség van a beruházások megvalósításához, azon keresztül a gazdasági teljesítmény és foglalkoztatottság növekedéséhez. Nem mindegy azonban, hogy mekkora ez a folyómérleg-hiány, mekkora kötelezettségek alakulnak ki a külföldi gazdasági szereplők irányába. Ugyanis a működő tőke beáramlása mellett ez más formákat is ölt: portfolió-befektetések, külföldi hitelek. Ezek pedig meglehetősen volatilisen alakulhatnak gazdasági változások esetén, vagyis a kockázatvállalási hajlandóság globális csökkenése esetén a fejlett országokhoz képest (igaz, nagyobb hozamot ígérő, de) kockázatosabb befektetési terepnek számító kelet-közép-európai gazdaságokból hirtelen megindulhat a töke kiáramlása, ami súlyos reálgazdasági következményekhez vezethet. ${ }^{76}$ Ez történt a 2007-2008-ban kezdődő válság során is.

${ }^{76}$ Érdemes hozzátenni, hogy a müködő tőke is mobilabbá, áramlása gyorsabbá vált az elmúlt évtizedekben. A gazdasági viszonyok megváltozása esetén (technikai és szabályozási okokból egyaránt) 


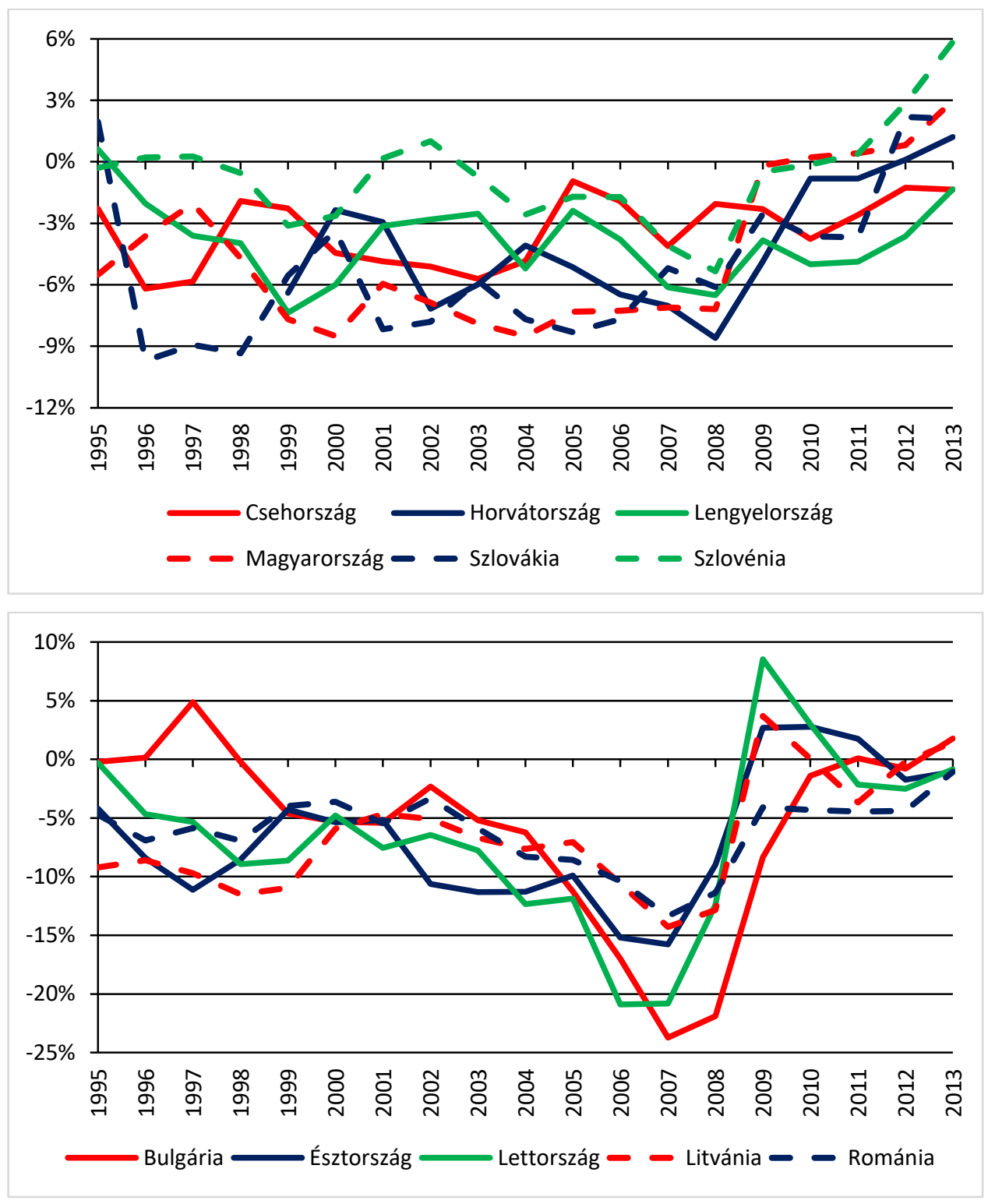

Saját szerkesztés az Eurostat (2016) adatai alapján

A 2008-at megelőző időszakban a térség országainak többsége jelentős mértékü, és sok esetben növekvő hiányt halmozott fel a folyó fizetési mérlegben. Horvátország, Magyarország és Szlovákia esetében ez éveken keresztül a GDP 6-8 százalékát jelentette, ami már a fenntarthatónak, különösebb sebezhetőséget nem okozónak tartott érték felett van. Bulgáriában, Romániában és a balti államokban azonban még ennél is lényegesen nagyobb volt a folyó fizetési mérleg hiánya, ráadásul a 2000-es évek elejétől kezdve folyamatosan és gyors ütemben nőtt. Észtországban, Litvániá-

egyre könnyebbé vált befejezni a termelést az egyik országban és rövid időn belül újrakezdeni akár a világ másik részén. 
ban és Romániában 2007-re a GDP 13-16 százalékára rúgott, míg Lettországban 21, Bulgáriában több mint 24 százalékon tetőzött. ${ }^{77}$

10. ábra: A külkereskedelmi nyitottság ((export + import) / GDP) alakulása

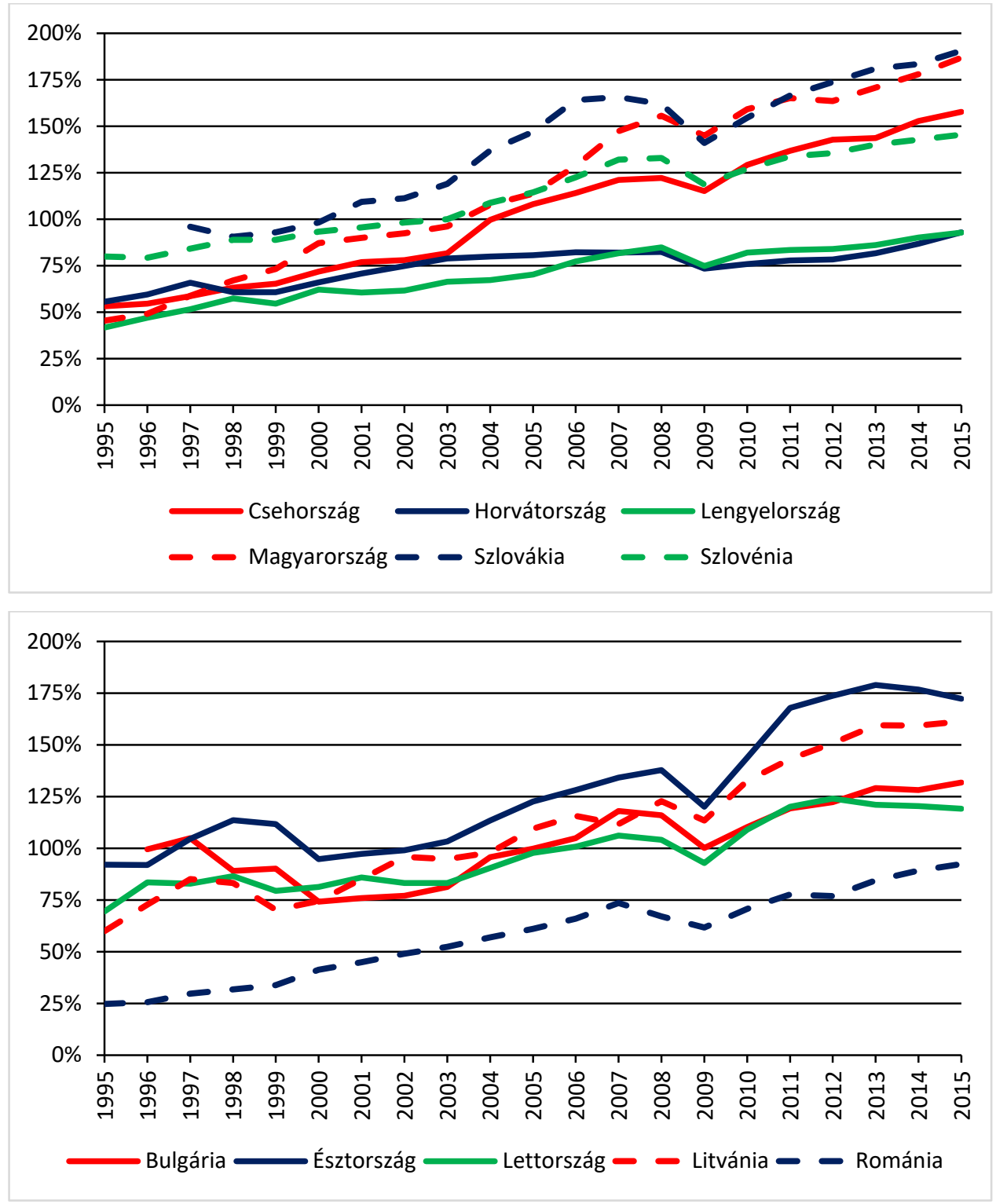

Saját szerkesztés az Eurostat (2016) adatai alapján

Ekkora mértékü egyensúlytalanság mellett hiába ért el a 2008-at megelőző években gyors növekedést a kelet-közép-európai régió, az ugyanúgy fenntarthatatlan, mint ha egy költségvetési túlköltekezés fütötte volna a gazdaságot (Magyarországon a külső egyensúlytalanság mellett ez is jellemezte a 2001-2006-os idősza-

77 A 8. ábrán látható, hogy ez pontosan az az időszak, amikor Bulgáriában ugrásszerüen megnőtt a külföldi közvetlen tőkeberuházások állománya. 
kot). ${ }^{78}$ Kornai (1972) szóhasználatával élve ez a növekedés inkább erőltetettnek tekinthető, nem harmonikusnak.

A gazdasági nyitottság egy másik - a növekedési teljesítmény és a sebezhetőség szempontjából egyaránt fontos - vonatkozását jelenti a külkereskedelmi nyitottság. A külkereskedelmi vagy reálgazdasági nyitottságot az export és import összegének GDP-hez viszonyított arányával mérjük. (10. ábra) A térség minden országában növekedett a külkereskedelmi forgalom GDP-aránya, még a Romániát jellemző, térségbeli legalacsonyabb érték is meghaladja a 80 százalékot (de a válság előtt is elérte a 75 százalékot), vagyis jelentős a nyitottság mértéke, a külső gazdasági kapcsolatok szerepe. Az országok többsége esetében az export és import összege megközelíti vagy meghaladja a bruttó hazai termék másfélszeresét. Az EU-csatlakozás mindenhol érezteti hatását, a csatlakozást követően megnőtt a nyitottság mértékének növekedési üteme. Az pedig természetes, hogy a régió két legnagyobb országa, Lengyelország és Románia e tekintetben elmarad a kelet-közép-európai átlagtól, hiszen a nagyobb belső piacméret egyrészt nagyobb felvevőpiacot, másrészt diverzifikáltabb termelési szerkezetet is jelent.

Látható, hogy a modellben kiemelt szerepe van a külső nyitottságnak - a külkereskedelem és a pénzügyi folyamatok terén egyaránt. Ez természetesen fontos forrása volt a fejlettebb nyugat-európai országokhoz való felzárkózásnak, részben a külkereskedelem által elért piacok, részben a kereskedelemmel és tőkebeáramlással öszszefüggő technológiatranszfer, részben a külföldi forrásokból finanszírozott beruházások révén. Azonban ez az erőteljes nyitottság sebezhetőséget is jelent.

Ennek a sebezhetőségnek több összetevője van - a nyitottság és a versenyképesség tekintetében is. A külkereskedelmi egyensúly hiánya, a nagy nettó import komoly problémákat okozhat, ha a finanszírozási forrását jelentő tőkebeáramlás elapad. A balti államokban, valamint Romániában és Bulgáriában a növekedést a belső kereslet jelentős bővülése vezérelte, a külkereskedelem (közvetlen) hozzájárulása 2000-2008 között negatív volt. (Marer, 2013, p. 247) Ez a versenyképesség romlását jelzi, aminek egy másik dimenziója a munkaerö-egységköltség (unit labour cost) alakulásában jelenik meg. A munkaerőköltség a három balti államban és Romániá-

${ }^{78}$ Antal (2004) könyve „utolsó utáni” fejezetének a „Távolodva a fenntarthatóságtól - új történet kezdődik, új tanulságokkal" címet adta. E fejezetben a magyar gazdaságban megjelenő egyensúlytalanságokkal foglalkozik, de mint láthatjuk a 2000-es években a többi kelet-közép-európai ország is komoly fenntarthatósági problémákkal küzdött. 
ban növekedett a leggyorsabban 2001 és 2008 között - 4-10-szer olyan gyorsan, mint az Egyesült Államokban. (i.m., p. 248)

A sebezhetőség másik összetevője, hogy a balti országokban és Romániában lényegesen nőtt a hitelállomány nagysága. Természetesen az sem mindegy, hogy ki és milyen módon finanszírozza ezt a hitelboomot, e tekintetben a legkisebb sebezhetőséget az jelenti, ha a hazai megtakarítók biztosítják a hitelnyújtás forrását. A régió számos országában azonban nem ez volt a helyzet. A külső adósság GDP-aránya Lettországban és Észtországban volt a legnagyobb 2007-ben, de másik négy országban (Magyarország, Románia, Szlovénia és Bulgária) is meghaladta a 100 százalékot. (i.m., p. 253)

Érdemes megemlíteni az árfolyam-politika szerepét is. A balti országok, valamint Bulgária által alkalmazott valutatanács (currency board) rendszere egy nagyon szigorú árfolyamrögzítést jelentett. Ha a rögzítés teljes mértékben hiteles, akkor gyakorlatilag megszünik, vagy legalábbis minimálisra csökken az árfolyamkockázat. Ez - az euró-bevezetés perspektívájával együtt - arra vezetett, hogy a hazai valutában jövedelemhez jutó gazdasági szereplők egyre nagyobb arányban halmoztak fel kötelezettségeket euróban, vagyis megnőtt a gazdaság külső adósságállománya. ${ }^{79}$ (Marer, 2013, Sutela, 2013)

A külkereskedelmi nyitottság is hozzájárul a sérülékenységhez, hiszen ha az aggregált keresletben nagy az export súlya, akkor a felvevőpiacok gazdasági visszaesése vagy lassulása (kiegészítve olyan egyéb tényezőkkel, mint például az Oroszország ellen bevezetett gazdasági szankciók) a vizsgált ország növekedését is visszaveti.

Mielőtt azonban a fent említett fenntarthatósági problémáknak és sérülékenységnek a pénzügyi válság nyomán megjelenő következményeivel folytatnánk, röviden kitérek az Európai Uniótól származó támogatásoknak a gazdasági növekedésben játszott szerepére. A külföldről érkező transzferek ugyanis jelentősen hozzá tudnak járulni a gazdaság bővüléséhez, anélkül, hogy a fentebb említett makroszintü egyensúlytalansági problémák felmerülnének. A kelet-közép-európai országok már az Európai Unióba való belépésüket megelőzően kaptak támogatást az előcsatlakozási alapokból, majd a csatlakozást követően mindegyikük jelentős mértékben nettó haszon-

\footnotetext{
${ }^{79}$ Hozzá kell tenni, hogy az euró-bevezetéssel kapcsolatos várakozások, illetve adott kamatfeltételek szigorú árfolyamrögzítés nélkül is vezethetnek külső eladósodáshoz, mint az Magyarország esetében is történt.
} 
élvezője lett az uniós költségvetésnek. Ennek oka természetesen az, hogy az új tagok a nyugat-európai országokhoz képest fejletlenebbek, így több támogatásra jogosultak a strukturális alapokból, másrészt pedig a bruttó nemzeti jövedelem (GNI) alapján meghatározott befizetési kötelezettségük is alacsonyabb összeget tesz ki.

\section{4. táblázat: Az Európai Uniótól származó nettó transzferek éves átlagos GDP-aránya}

\begin{tabular}{|c|c|c|}
\hline Ország & $\begin{array}{c}\text { 2000-2006-os } \\
\text { költségvetési ciklus }\end{array}$ & $\begin{array}{c}2007-2013-\text { as } \\
\text { költségvetési ciklus }\end{array}$ \\
\hline Bulgária & $1,04 \%$ & $2,21 \%$ \\
\hline Csehország & $0,23 \%$ & $1,23 \%$ \\
\hline Észtország & $0,97 \%$ & $3,11 \%$ \\
\hline Lengyelország & $0,49 \%$ & $2,32 \%$ \\
\hline Lettország & $1,08 \%$ & $3,11 \%$ \\
\hline Litvánia & $1,45 \%$ & $4,14 \%$ \\
\hline Magyarország & $0,45 \%$ & $2,99 \%$ \\
\hline Románia & $0,63 \%$ & $1,36 \%$ \\
\hline Szlovákia & $0,47 \%$ & $1,52 \%$ \\
\hline Szlovénia & $0,30 \%$ & $0,93 \%$ \\
\hline
\end{tabular}

Saját számítások az EC (2015) és az Eurostat (2016) adatai alapján.

Megjegyzés: Horvátország nem szerepel a táblázatban, mert csak 2013-ban, vagyis a második időszak végén csatlakozott az Európai Unióhoz.

A 4. táblázatban látható a nettó uniós transzferek átlagos GDP-aránya a 2000-2006-os és a 2007-2013-as költségvetési ciklusban. A csatlakozás előtt ez csak az EU-tól kapott támogatásokat jelenti, azt követően pedig a befizetések és támogatások nettó egyenlegét. Vagyis ez mutatja, hogy az EU-s források mennyivel növelik meg az egyes tagországok rendelkezésre álló jövedelmét, azon keresztül az aggregált keresletet. A támogatások hatása főleg a második ciklusban jelentős, két okból is: egyrészt mert ebben az időszakban a taggá váló országok nagyobb összegü támogatásra váltak jogosulttá, másrészt a pénzügyi válság hatására ebben az időszakban lelassult az FDI-beáramlás (lásd 8. ábra), ami felértékeli az uniós források szerepét.

E transzferek esetében nem merül fel közvetlenül a fenntarthatóság problémája, de a helyzet a külső tőkebevonás által hajtott növekedés általánosabb képéhez abból a szempontból hasonló, hogy ezekre a támogatásokra sem lehet hosszú távon számítani, vagyis érdemi lassulást tapasztalhat az a gazdaság, amelynek növekedése nagymértékben az uniós forrásoktól függ. Mivel nagyrészt beruházások támogatásáról van szó, ezért e transzferek nem csak közvetlenül az aggregált kereslet emelésén keresztül hathatnak a növekedésre, hanem a tökeállomány bővítése révén a gazdaság 
hosszabb távú jövedelemtermelési képességét is befolyásolják. Az uniós támogatások e szempontból vett hatékonyságának vizsgálata túlmutat jelen dolgozat keretein.

\subsection{Gazdasági visszaesés és ütemvesztés}

Ha az előző alfejezetben tárgyalt sérülékenységi tényezőket összevetjük, akkor nem meglepő, hogy a több szempontból is sebezhetőnek bizonyuló balti államokat sújtotta a legnagyobb arányú visszaesés a 2007-2008-ban kirobbant pénzügyi és gazdasági válság nyomán. Ahogy az 5. táblázatban látható, mindhárom országban 14-15 százalékkal esett vissza a reál GDP egy év alatt. Észtországban és Lettországban már 2008-ban csökkent a gazdaság teljesítménye, Litvániában ez nem következett be, de a növekedési ütem itt is lassult: az előző évi több mint 11 százalékról 3 százalék alá.

A baltiakat sújtó gazdasági visszaesés súlyossága kapcsán a rögzített árfolyamrendszer alkalmazásának még egy vonatkozását meg kell említeni: ebben az esetben ugyanis nincs lehetőség arra, hogy valuta-leértékelödés révén javuljon az ország export-versenyképessége, illetve tökevonzó képessége. Így az árfolyam nem képes „pufferként” viselkedni, a reálgazdaság visszaesése erőteljesebb. A versenyképesség visszaszerzéséhez pedig belső leértékelésre (a bérek csökkenésére) van szükség.

\section{5. táblázat: A pénzügyi válság hatása a kelet-közép-európai országokban}

\begin{tabular}{|c|c|c|c|}
\hline Ország & $\begin{array}{c}\text { A GDP változása } \\
\text { 2008-2009 között }\end{array}$ & $\begin{array}{c}\text { A GDP-visszaesés } \\
\text { évei }\end{array}$ & $\begin{array}{c}\text { Kumulált GDP- } \\
\text { csökkenés mértéke }\end{array}$ \\
\hline Bulgária & $-4,22 \%$ & 2009 & $4,22 \%$ \\
\hline Csehország & $-4,84 \%$ & 2009 & $4,84 \%$ \\
\hline Észtország & $-14,72 \%$ & $2008-2009$ & $19,35 \%$ \\
\hline Horvátország & $-7,38 \%$ & $2009-2014$ & $12,46 \%$ \\
\hline Lengyelország & $2,82 \%$ & --- & --- \\
\hline Lettország & $-14,35 \%$ & $2008-2010$ & $20,55 \%$ \\
\hline Litvánia & $-14,81 \%$ & 2009 & $14,81 \%$ \\
\hline Magyarország & $-6,56 \%$ & 2009 & $6,56 \%$ \\
\hline Románia & $-7,07 \%$ & $2009-2010$ & $7,81 \%$ \\
\hline Szlovákia & $-5,49 \%$ & 2009 & $5,49 \%$ \\
\hline Szlovénia & $-7,80 \%$ & 2009 & $7,80 \%$ \\
\hline
\end{tabular}

Saját számítások az Eurostat (2016) adatai alapján

A balti országok gazdaságpolitikáját Kutasi (2014) is elemezte, és a passzív makrogazdasági populizmus szerepét emelte ki. Az itt tapasztalt populizmus attól 
passzív, hogy nem költekezésben, a közkiadások megugrásában nyilvánul meg ${ }^{80}$, hanem egyéb egyensúlytalanságok kiigazításának elmaradásában. Ez ebben az esetben a külső egyensúly hiányát jelenti, amelynek a gazdaságpolitika által történő helyreállítása rövid távon csökkentette volna az állampolgárok jólétét, hosszú távon viszont fenntarthatóbbá tette volna a gazdasági növekedést.

Ahogy az a 3. ábráról látható, a hatalmas mértékü recessziót gyors kilábalás követte a balti országokban: 2011-ben Észtország 8,26 százalékos, Litvánia 6,11 százalékos, Lettország pedig 5,00 százalékos gazdasági növekedést produkált - ez a három leggyorsabb növekedési ütem volt abban az évben az EU országai között. A litván reál GDP 2014-re meghaladta, az észt és lett megközelítette a válság előtti szintet. A növekedés újraindulása tekintetében hasonló pályát írt le a szlovák, a bolgár, illetve tulajdonképpen a román gazdaság is: a baltiaknál mérsékeltebb, de így is jelentős (5-8 százalékos) visszaesést gyors kilábalás követett.

A válság a régió más országaiban a $\mathrm{V}$ helyett inkább $\mathrm{W}$ alakot öltött: Csehországban és Szlovéniában 2012-2013-ban, Magyarországon 2012-ben csökkent a GDP. Hazánk abból a szempontból is külön figyelmet érdemel, hogy a korábbi évek fenntarthatatlan költségvetési politikája miatt a válság idején a kormányzat nem hogy nem tudta expanzív lépésekkel enyhíteni a visszaesést, de a közpénzügyi helyzet stabilizálása érdekében kénytelen volt kifejezetten pro-ciklikus gazdaságpolitikát folytatni, ami mélyítette a recessziót. A válság magyarországi elhúzódásához viszont a 2008 előttről örökölt költségvetési problémák mellett néhány hibás vagy rosszul időzített gazdaságpolitikai döntés is hozzájárult: az egykulcsos jövedelemadó a fogyasztásra, a szektorális különadók kivetése a beruházásokra hatott negatívan. A legsúlyosabb helyzetben viszont tagadhatatlanul Horvátország van, ahol 2009-2014 között minden évben csökkent a GDP.

A másik véglet Lengyelország, amely az EU egyetlen országa, ahol 2009-ben sem csökkent a GDP. A lengyel gazdaság - jelentős részben méretéből is adódóan kereskedelmi és pénzügyi értelemben is kevésbé nyitott a térség más országaihoz képest, így kevésbé volt kitéve az egész fejlett világot sújtó recesszió hatásainak. Másrészt a térség országai közül Lengyelországban nőtt a leglassabban a munkaerőegységköltség, ami régiós összevetésben jelentősen javította az ország versenyképességét. (Marer, 2013, p. 248) Természetesen a lengyel gazdasági teljesítmény sem

${ }^{80}$ A balti államok költségvetési politikája meglehetősen konzervatív (alacsony újraelosztás és államadósság, egyensúly közeli helyzet) lásd az 5.4. alfejezetet. 
„hibátlan”, a fiskális politika terén érdemi egyensúlytalanságok mutatkoznak. A költségvetési hiány ingadozó mértékben, de gyakran lényegesen meghaladta a GDP 3 százalékát, az államadósság a 2000-es években folyamatosan növekvő pályára állt. Kozenkow (2014) abban látja a gazdaságpolitika hibái mellett is alapvetően stabil gazdasági növekedés egyik fő magyarázatát, hogy az informális intézmények (normakövetés, a kemény munkába és önálló felelősségvállalásba vetett hit stb.) erősnek mondhatók.

Noha a gazdaság kibocsátása nem esett vissza, a növekedési ütem lassulását Lengyelország sem kerülhette el. Ez a jelenség minden régiós tagországban megfigyelhető. A 6. táblázat a 2002-2008 közötti és a 2009-2015 közötti (már a visszaesés utáni) növekedési ütemeket veti össze. Jól látható, hogy mindegyik vizsgált országban jelentősen csökkent a reál GDP növekedési üteme a pénzügyi válságot követően, mindössze két országban marad az ütemcsökkenés 2 százalékpont alatt: Lengyelországban, valamint Magyarországon, ahol már a recessziót megelőzően is régiós összevetésben kifejezetten alacsony volt a gazdaság bővülésének sebessége. Ez azt is jelenti, hogy a balti vagy szlovák gazdaságok válság utáni gyors helyreállása csak egy átmeneti állapotnak tekinthető.

6. táblázat: A GDP-növekedési ütem mérséklődése a pénzügyi válság után

\begin{tabular}{|c|c|c|c|}
\hline Ország & $\begin{array}{c}\text { Átlagos éves GDP- } \\
\text { növekedési ütem } \\
2002-2008 \text { között }\end{array}$ & $\begin{array}{c}\text { Átlagos éves GDP- } \\
\text { növekedési ütem } \\
2009-2015 \text { között }\end{array}$ & $\begin{array}{c}\text { Az átlagos éves } \\
\text { GDP-növekedési } \\
\text { ütem változása }\end{array}$ \\
\hline Bulgária & $6,49 \%$ & $1,27 \%$ & $-5,21 \%$ \\
\hline Csehország & $5,01 \%$ & $1,69 \%$ & $-3,31 \%$ \\
\hline Észtország & $5,81 \%^{*}$ & $3,44 \%$ & $-2,37 \%$ \\
\hline Horvátország & $4,29 \%$ & $-0,67 \%$ & $-4,96 \%$ \\
\hline Lengyelország & $4,93 \%$ & $3,05 \%$ & $-1,88 \%$ \\
\hline Lettország & $7,49 \%^{*}$ & $2,38 \%{ }^{* *}$ & $-5,11 \%$ \\
\hline Litvánia & $7,62 \%$ & $3,27 \%$ & $-4,34 \%$ \\
\hline Magyarország & $3,02 \%$ & $1,54 \%$ & $-1,48 \%$ \\
\hline Románia & $6,89 \%$ & $1,85 \%{ }^{* *}$ & $-5,05 \%$ \\
\hline Szlovákia & $6,99 \%$ & $2,82 \%$ & $-4,16 \%$ \\
\hline Szlovénia & $4,51 \%$ & $0,65 \%$ & $-3,85 \%$ \\
\hline
\end{tabular}

Saját számítások az Eurostat (2016) adatai alapján

Megjegyzés: *Észtországban és Lettországban már 2008-ban csökkent a GDP, a 2002-2007 közötti átlagos éves növekedési ütem Észtországban 8,21\%, Lettországban 9,86\%. ** Lettországban és Romániában 2010-ben is csökkent a GDP, a 2010-2015 közötti átlagos éves növekedési ütem Lettországban $3,66 \%$, Romániában 2,38\%. 
A 2. fejezetben tárgyalt növekedéselméleti megközelítések három lehetséges narratívát is kínálnak az ütemvesztés magyarázatára. Az egyik értelmezési lehetőség a Solow-modellre épít: eszerint a válságot megelőző időszak tulajdonképpen a kezdeti alacsony tőkeellátottság állapotából az egyensúlyi növekedési pálya felé való konvergenciát jelentette. Ezt az időszakot a tőkefelhalmozás átlag feletti üteme, és az ezáltal vezérelt, a hosszú távon elérhetőnél gyorsabb gazdasági növekedés jellemzi. Ezek megfelelnek a kelet-közép-európai tapasztalatoknak, de ez az értelmezés ezzel együtt is csak akkor lehet helyes, ha további kiegészítéseket teszünk hozzá.

Egyrészt a Solow-modellben a konvergencia folyamán a növekedési ütem fokozatosan lassul az egyensúlyi értékre, míg a régió országaiban előbb hirtelen megugró növekedés volt jellemző a transzformációs recessziót követően, majd a pénzügyi válság során visszaesés és a növekedési ütem hirtelen lassulása. Ezt magyarázhatja az, hogy - mint a 2.9. alfejezetben utaltam rá - a vizsgált országok kis, nyitott gazdaságnak tekinthetők, tehát a tőkefelhalmozást nem csak, illetve nem elsősorban a belső megtakarítások mozgatják, hanem a külföldi források elérhetősége. A rendszerváltozás során a tőkeáramlások gyors liberalizációja zajlott le a térség országaiban, ami a tőketulajdonosok számára elérhetővé tette a magasabb megtérülésü, de korábban számukra nem elérhető befektetési lehetőségeket. Ezzel megnyílt az út a tőkebevonáson alapuló gyors növekedés modellje előtt. A pénzügyi válság pedig a megnövekvő bizonytalanság miatt a kockázatkerülő magatartás erősödését eredményezte, ami visszafogta a befektetések kínálatát, emiatt pedig hirtelen lecsökkent a tőkefelhalmozás és a gazdasági növekedés üteme. Vagyis a növekedési ütemeknek a Solow-modell alapján várhatónál gyorsabb változását egyrészt a gazdaságok nyitottsága és emiatt a globális pénzügyi folyamatok, másrészt az intézmények változása okozhatja.

Egy másik kiegészítésre azért van szükség a Solow-féle narratívához, mert mint az alfejezet későbbi részében látni fogjuk - nem csak lelassult a tőkefelhalmozás, hanem bizonyos országokban kifejezetten csökkent is a tőkeállomány a válságot követő néhány évben. Ez a Solow-modellben csak akkor lenne lehetséges, ha az egyensúlyinál nagyobb a tőkeellátottság, vagyis a tőketulajdonosok a válságot megelőzően „túlbefektetést” hajtottak végre. Ez csak úgy képzelhető el, ha bevonjuk a modell gondolatkörébe az információs problémákat, illetve a gazdasági szereplők korlátozott racionalitását. 
Egy másik értelmezési lehetőséget a Jánossy-féle trendvonal elmélete adhat. Eszerint a válságot megelőző gyors növekedés tulajdonképpen pusztán a transzformációs recesszió (vagy tágabb értelemben a szocializmus évtizedei) utáni helyreállítási periódusnak tekinthető. A háborúkat, válságokat követő helyreállítási periódusokat a hosszú távon elérhetőnél gyorsabb növekedés jellemzi, mert a fizikai tőkeállományt pótolni kell a korábbi veszteségek után. Ez azonban csak addig hajtja a gazdaságot, amíg vissza nem ér a növekedés trendvonalára, aminek meredekségét tartósabb tényezők (humán tőke, intézményrendszer) határozzák meg. Az utóbbi évek lassabb növekedése ez alapján a trendvonalra való visszatérést jelzi.

Végül egy harmadik magyarázat alapját a folyófizetésimérleg-korlátos modellek adhatják. E modellek szerint a kis, nyitott gazdaságok növekedését az exportpiacok bővülése, a tőkebeáramlás, valamint a cserearány változása határozza meg. Az UNCTAD (2016) statisztikái alapján 2008 és 2014 között a kelet-közép-európai országok cserearány-mutatói nem változtak jelentősen - Magyarország kivételével, hazánkban ugyanis javult a cserearány. ${ }^{81}$ Vagyis az elmélet értelmében a növekedési ütem csökkenése a felvevőpiacok gazdasági lassulására, illetve a tőkebeáramlás leállására vezethető vissza. Ezt alátámasztják a tapasztalatok, hiszen az EU-15 országok (akik a kelet-közép-európai országok legfontosabb kereskedelmi partnerei) átlagos növekedési üteme mintegy felére esett vissza 2000-2008 és 2009-2015 között, és a lassulás a világgazdaság egészére jellemző. A működőtőke-beáramlás is mindenhol elakadt, Magyarország 2012-es értéke (amelyet elsősorban a külföldi tulajdonú bankok tőkepótlása okozott) e tekintetben kivételesnek tekinthetö.

Mindhárom fenti magyarázat arra a következtetésre vezet, hogy a korábbi, tőkefelhalmozás által vezérelt gyors növekedés visszatérésére nem számithatunk, a külső tényezők kedvezőtlen megváltozása (legyen szó az exportpiacok mérséklődő gazdasági növekedéséről vagy a csökkenő globális befektetési hajlandóságról), illetve a növekedés belső forrásainak (mint amilyen a tőkeellátottság alacsony fokának köszönhető magas tőkemegtérülés) elapadása ütemvesztéshez kellett, hogy vezessen. Ez azt is jelenti, hogy a Nyugat-Európához viszonyított reálkonvergencia is várhatóan lassabb lesz a következő időszakban, mint 2008-at megelőzően.

${ }^{81}$ A 2000-2008 között cserearány-változások tekintetében komoly különbségek voltak a térség országai között: Bulgária, Lettország és Románia számára előnyösen, míg Észtország, Magyarország vagy Szlovákia számára hátrányosan alakultak a cserearányok. (UNCTAD, 2016) 


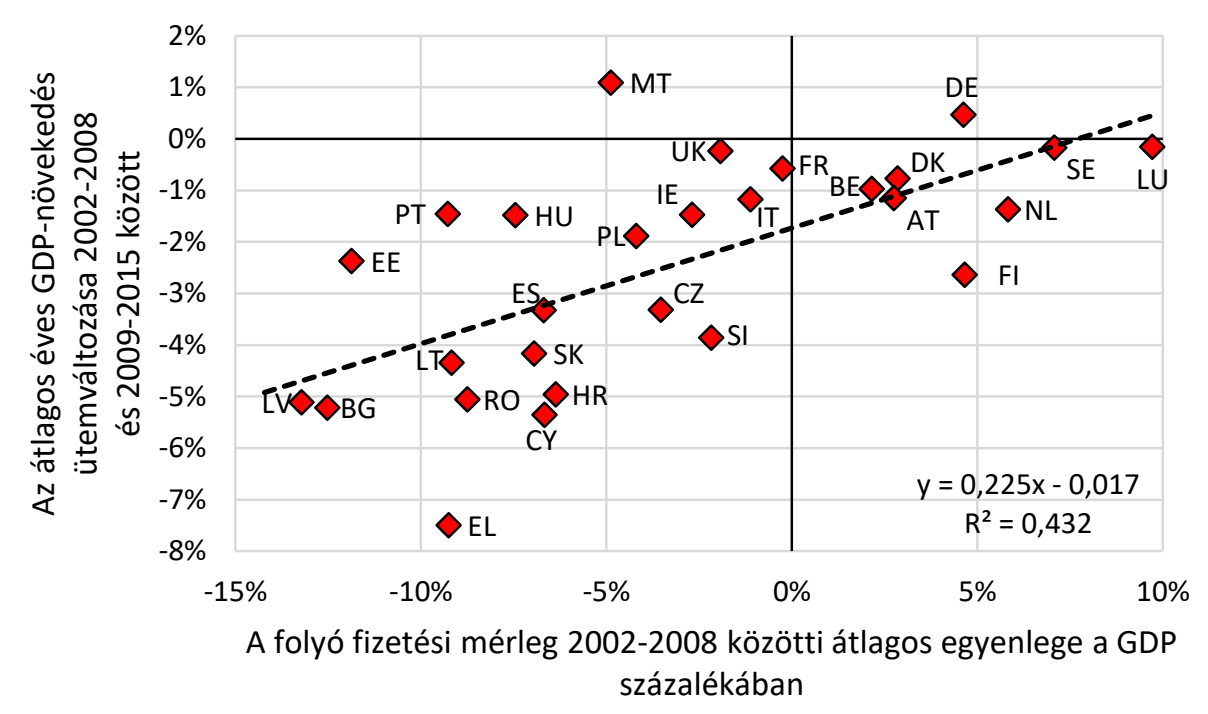

Saját szerkesztés az Eurostat (2016) adatai alapján

Megjegyzés: Írország 2015-ös GDP-je egy 2016. nyári adatrevízió eredményeként kiugróan magas lett (több mint 26 százalékkal nagyobb a 2014-es értéknél), ezért Írország esetében a 2009-2014 közötti átlagos növekedési ütemet használtam az ütemváltozás kiszámolásához. Jelmagyarázat: AT: Ausztria, BE: Belgium, BG: Bulgária, CY: Ciprus, CZ: Csehország, DE: Németország, DK: Dánia, EE: Észtország, EL: Görögország, ES: Spanyolország, FI: Finnország, FR: Franciaország, HR: Horvátország, HU: Magyarország, IE: Írország, IT: Olaszország, LT: Litvánia, LU: Luxemburg, LV: Lettország, MT: Málta, NL: Hollandia, PL: Lengyelország, PT: Portugália, RO: Románia, SE: Svédország, SI: Szlovénia, SK: Szlovákia, UK: Egyesült Királyság

A 11. ábra a kelet-közép-európai országokat leginkább jellemző egyensúlytalansági tényező (a folyó fizetési mérleg hiánya) és a növekedési ütemvesztés közötti kapcsolatot mutatja az Európai Unió országaiban. A legerőteljesebb lassulást azok az országok voltak kénytelenek elszenvedni 2009 után, ahol az átlagosnál (és a hagyományosan elfogadhatónak gondoltnál) lényegesen nagyobb volt a külső egyensúlytalanság: egy százalékponttal magasabb válság előtti folyófizetésimérleg-hiány 0,225 százalékponttal nagyobb növekedési ütemvesztéssel járt a visszaesést követő években. Figyelembe véve a kelet-közép-európai országok többségének korábbi kiugró mérleghiányait, ennek fenntarthatatlansága sokat megmagyaráz a növekedési ütem megfigyelt csökkenéséböl.

A válság során egy nagyon erőteljes kiigazitás ment végbe a térségbeli országok folyó fizetési mérlegében, ez alól csak Csehország a kivétel, ahol a korábbi évek alapján a legkevésbé is lett volna szükség ilyen kiigazításra, hiszen a folyómérleghiány éveken keresztül a GDP 2-4 százaléka között alakult. Lengyelországban és 
Szlovákiában fokozatosabban, a többi országban meglehetősen hirtelen ment végbe a folyó fizetési mérleg hiányának nagymértékü csökkenése, illetve számos esetben többletbe fordulása. Ez három tényezővel is magyarázható. A GDP visszaesése önmagában is mérsékli a GDP-arányos folyómérleg-hiány értékét (értelemszerüen a többletbe fordulásra nem lehet magyarázat). Másrészt a kelet-közép-európai országokban mindenhol nagyobb volt az importban, mint az exportban mutatkozó visszaesés, ami annak is köszönhető, hogy ezekben az országokban jelentősebb jövedelemcsökkenés következett be, mint fö felvevőpiacaik (például Németország, Ausztria) esetében. Így a hazai importkereslet jobban visszaesett, mint az export iránti külpiaci kereslet. Harmadrészt az importált gépek, berendezések, technológia segítségével megvalósuló beruházások is megtorpantak, ami szintén a külkereskedelmi arányok eltolódását eredményezte. A legnagyobb változás a korábban legnagyobb egyensúlytalanságot mutató Bulgária és Lettország folyó fizetési mérlegében ment végbe: előbbi országban 24, utóbbiban 29 százalékponttal javult ${ }^{82}$ az egyenleg 2007 és 2009-2011 között.

A Függelék F4. ábráján jól megfigyelhető a beruházási teljesítmény zuhanása a válság következményeként. Általában is megfigyelhető (a transzformációs viszszaesés során is ez volt a helyzet), hogy a beruházások egy válság során a lakossági fogyasztásnál és a GDP-nél nagyobb mértékben esnek vissza, ez a jelenség a mostani válságot is jellemzi. Lettországban, majd 2012-től Szlovéniában (illetve 2014-ben Szlovákiában is) negatívba fordult a nettó beruházási ráta, de 2012-re Magyarország adata is vészesen közeledett a nullához. Hazánkban a recesszió hatásai mellett a gazdaságpolitika erőteljes változtatásaiból fakadó bizonytalanság, illetve néhány konkrét lépés (például szektorális különadók kivetése) is visszavetette a beruházási aktivitást. $\mathrm{Az}$ is látható azonban, hogy a válság Lengyelországban is éreztette hatását, hiszen a nettó beruházási ráta kismértékben ugyan, de mérséklődött. Vagyis az ország gazdasága hiába produkált növekedést, a beruházási hajlandóság globális csökkenésének hatásai alól nem vonhatta ki magát.

${ }^{82}$ Önmagában a folyó fizetési mérleg egyenlege nem tekinthető monoton skálának, nem állíthatjuk, hogy a kisebb hiány vagy a nagyobb többlet mindig jobb (vagy egyáltalán hogy a többlet jobb a hiánynál). Az említett országokat korábban jellemző hatalmas egyensúlytalanság korrekciója viszont mindenképpen javulásnak nevezhető. 


\subsection{A tartós növekedés feltételei}

A fejezetet a tartós gazdasági növekedés feltételeihez kapcsolódó néhány gondolattal zárom. Ezek részletes kifejtése szétfeszítené a dolgozatot, azonban megemlítésüket lényegesnek gondolom.

A növekedéselméleti modellek megoszlanak abban a tekintetben, hogy a fizikai tőke felhalmozása eredményezhet-e tartós gazdasági fejlődést. A Harrod-Domar modell (2.3. alfejezet) vagy az AK-modell (2.6. alfejezet) megközelítése szerint igen, azonban más irányzatok azt emelik ki, hogy a tökeellátottság növelése inkább csak felzárkózási időszakokban (legyen az akár az egyensúlyi növekedési pályához való konergencia a Solow-modellben, akár egy Jánossy-féle helyreállítási periódus) eredményezik az egy före jutó jövedelem növekedését, a tartós gyarapodás ütemét más tényezők magyarázzák. A beruházások ezzel együtt is fontosak, hiszen a termelékenység növekedését kiegészítő tőkefelhalmozásra akkor is szükség van, ha hosszú távon nem lehet ez a növekedés fö motorja. E tekintetben nagy jelentősége van két már említett fejleménynek: az egyik a kelet-közép-európai országokba áramló működő tőke mennyiségének utóbbi években megfigyelhető csökkenése, a másik az európai uniós támogatások jövőben várható mérséklődése.

A fizikai tőke mellett fontosak - sőt, hosszú távon fontosabbak - az emberi erőforrások. Ez egyrészt demográfiai kérdés is, és ebben a tekintetben a volt szocialista országok szempontjából nagyon kedvezőtlen fejlemény az EU-n belüli jelentős, kelet-nyugati irányú belső migráció, vagyis a tömeges elvándorlás a fejlettebb tagállamok irányába. A számszerü népességcsökkenés mellett ez a társadalom és munkaerőpiac szerkezetének a megváltozását is jelenti, hiszen nagyobb arányban a képzettebb és kezdeményezőkészséggel, vállalkozókedvvel inkább rendelkező fiatalok keresnek külföldön munkát. Ez az „agyelszívás” („,brain-drain”) a kelet-közép-európai gazdaságok rendelkezésére álló humán tőke mennyiségét jelentősen csökkenti.

Az emberi tőke szempontjából az oktatás szerepe is fontos, az utóbbi időben leginkább a felsőoktatásra helyeződik a hangsúly. A kelet-közép-európai országok mindegyike gyors felsőoktatási expanzión ment keresztül a rendszerváltozás után. Bulgária kivételével mindenhol jelentősen nőttek a hallgatói létszámok a 2000-es évtized közepéig-végéig (általában 1998-hoz képest ${ }^{83}$ 60-120 százalékkal, Romániában pedig ennél is lényegesen nagyobb mértékben), azóta azonban egy visszaigazo-

\footnotetext{
${ }^{83}$ Az Eurostat (2016) adatbázisában 1998-tól érhetők el a hallgatói létszámok.
} 
dás, a hallgatói létszám csökkenése figyelhető meg. Ennek több oka is van. Egyrészt a gyermekszám csökkenésének hatása a felsőoktatásban értelemszerüen késleltetve jelenik meg, a rendszerváltozás környékén bekövetkező visszaesés pontosan ebben az időszakban érte el a felsőoktatást, ekkorra érték el a 18 éves kort a kisebb létszámú generációk. Másrészt a gazdasági válság hatására a kormányzatok takarékossági intézkedésekre kényszerültek, a kevesebb forrás pedig kevesebb hallgató képzését teszi lehetővé. Egy harmadik magyarázó tényező, hogy a válság következtében megváltozott munkaerö-piaci helyzetben (kiegészülve a finanszírozási helyzet változásaival) csökkent a felsőoktatásban való részvétel relatív megtérülése, ami a hallgatói kereslet mérséklődése irányába hat.

A hallgatói létszám utóbbi években megfigyelhető csökkenésének hatása még nem látható a végzettségi arányok alakulásában, a korábbi expanzió annál inkább. Minden vizsgált országban jelentősen nőtt a felsőfokú végzettségüek aránya, míg a legfeljebb alapfokú képzésben részesülők aránya mérséklődött. (Eurostat, 2016) A hallgatói létszám csökkenése miatt e trend lassulása, visszafordulása várható. Mindez természetesen az oktatás, illetve humántőke-felhalmozás mennyiségi oldalát ragadja csak meg, emellett a képzés minősége is számít.

Végül fontos kiemelni, hogy a gazdasági teljesítményben, növekedési képességben mutatkozó különbségek egyik legfőbb magyarázata a különböző országban kialakult intézményrendszer eltéréseiben keresendő. A kelet-közép-európai volt szocialista országokra vonatkozóan ez azt is jelenti, hogy a fejlettebb gazdaságokhoz való tartós felzárkózásnak is záloga a megfelelő piacgazdasági intézményrendszer kialakulása és múködtetése. A rendszerváltozást követő években a térség országaiban kiépültek a piacgazdaság müködéséhez szükséges intézmények (lásd ez ügyben az EBRD, 2016, tranzíciós indikátorait), majd az uniós csatlakozás további hasonulást eredményezett a nyugat-európai sztenderdekhez. Ez azonban csak a formális intézményekre vonatkozik, a növekedési lehetőségek (és a társadalom jóléte) szempontjából nagyon fontos ezek működésének minősége és stabilitása, illetve az ezeket kiegészítő informális intézmények. Ebben a tekintetben - akár az adómorálra, akár a korrupcióval kapcsolatos tapasztalatokra gondolunk - van lemaradása a volt szocialista országoknak Nyugat-Európához viszonyítva, azonban a térségen belül is vannak jobban teljesítők (például a balti államok). Ez azt jelzi, hogy a többi kelet-közép-európai országban is van lehetőség az intézmények minőségének javítására. 


\section{FISKÁLIS POLITIKA ÉS GAZDASÁGI NÖVEKEDÉS KELET-KÖZÉP-EURÓPÁBAN}

\subsection{Bevezetés}

Ebben a fejezetben az előzőekben elmondottak folytatásaként a költségvetési politika kérdéseire helyezem a hangsúlyt. Az intézményi feltételek, gazdasági környezet tekintetében a makrogazdaság-politika alakulása fontos meghatározója egy ország növekedési lehetőségeinek. Az alábbiakban előbb a fiskális politika és gazdasági növekedés kapcsolatát vizsgáló szakirodalmat tekintem át röviden kiegészítve az Európai Unió országaira vonatkozó empirikus eredményekkel, majd vázlatosan bemutatom a térségbeli országok költségvetési helyzetét az államháztartás mérete, a költségvetés egyenlege és az államadósság tekintetében. Ezt követően két specifikus témával foglalkozom, amelyek a kelet-közép-európai régióban külön figyelemre érdemesek: a térségbeli országok adópolitikájának közös vonásaival, illetve a politikai költségvetési ciklusok jelenségével.

\subsection{A fiskális politika és a gazdasági növekedés kapcsolata}

A keynesi elmélet alapján a kormányzat rövid távon képes keresletszabályozással beavatkozni a reálgazdasági folyamatokba: élénkítheti a növekedést, illetve egy megszorítás pedig negatívan hat rá. Hosszabb távon azonban ellenkező irányú hatások dominálhatnak, vagyis az állandósuló expanzív politika ronthatja a hosszú távú növekedési lehetőségeket, míg egy stabilizáció a rövid távú áldozatok árán növelheti a GDP-bővülés ütemét. Sőt, a nem-keynesi hatások már rövid távon is megjelenhetnek. Egy hiteles és jól felépített költségvetési konszolidáció csökkentheti a jövőbeli adók szintjére vonatkozó várakozásokat, és így a várható életpálya-jövedelmük alapján optimalizáló gazdasági szereplők már jelenben is növelhetik fogyasztásukat. A költségvetési politika kiszámíthatóságának és fenntarthatóságának javulása a beruházási hajlandóságot is élénkítheti, így a fogyasztás és beruházás bővülése több mint kompenzálhatja a költségvetési kiadások visszafogásának közvetlen hatását. Az, hogy a keynesi vagy a nem-keynesi hatások dominálnak-e, a konkrét intézkedéseken, a költségvetési konszolidáció szerkezetén és a gazdaságpolitika általános hitelességén múlik. 
Az átfogó növekedési modellekben a gazdaságpolitika közvetlenül nem jelenik meg. Természetesen vannak olyan (exogénnek feltételezett) változók, amelyeket valójában gazdaságpolitikai intézkedések is befolyásolnak (például a Solow-modell megtakarítási rátája, a hasznosságmaximalizáló fogyasztókra építő modellek diszkontrátája, a humántőke-modellek erőforrás-megosztási paraméterei stb.), azonban ezek magyarázata többnyire viszonylag kevés hangsúlyt kap az elméletek kapcsán. Ezeken a paramétereken keresztül viszont az is látható, hogy a gazdaságpolitika az elérhető jövedelmek szintjére, sőt növekvő mérethozadék feltételezése esetén a növekedési ütemekre is hatással lehet. Az elmúlt két-három évtizedben számos olyan tanulmány látott napvilágot, amelyek a költségvetési politika hatását vizsgálták a gazdasági növekedés ütemére. Az alábbiakban ezekből válogatok.

A költségvetési kiadások elvileg pozitív és negatív hatást is gyakorolnak a reálgazdasági folyamatokra. Természetesen szükség van bizonyos közjavak, közszolgáltatások kormányzati biztosítására a gazdaság megfelelő müködéséhez, valamint a kormányzat végrehajthat olyan beruházásokat, amelyek szintén elösegíthetik a növekedést (infrastruktúra-fejlesztés stb.). Önmagában a redisztribúció is hasznos lehet a fejlődés szempontjából, hiszen a társadalmi egyenlőtlenségek erősödése negatív hatással van a gazdasági növekedés ütemére. ${ }^{84}$ Másfelől viszont a kormányzati kiadásokat finanszírozni kell. Ez történhet adók vagy hitelek révén. Az adók általában torzító hatásúak ${ }^{85}$, így csökkentik a piaci mechanizmus hatékonyságát, visszavetik a beruházásokat, míg a hitelből történő finanszírozás a magánberuházások elől von el megtakarításokat (kiszorítási hatás). Ráadásul az sem biztos, hogy a közösségi beruházások kellő hatékonyságúak, megfelelő mértékben járulnak hozzá a későbbi növekedéshez, illetve hogy a kormányzati jövedelem-újraelosztás valóban a szándékolt mértékben csökkenti az egyenlőtlenségeket. A magas költségvetési hiány esetében azt is megjegyezhetjük, hogy a kormányzat gyengeségét jelezheti és így bizonytalanságot szülhet.

Az empirikus eredmények gyakorlatilag egyöntetünek mondhatók abban a tekintetben, hogy mind a kormányzati költekezés negatív hatására vonatkozó elméleti megfontolásokat támasztják alá. Ez természetesen nem jelenti azt, hogy bizonyos javak előállításának költségvetésen keresztül történő finanszírozása eleve a növeke-

\footnotetext{
${ }^{84}$ Lásd Aghion, Caroli és García-Penalosa (1999) tanulmányát.

${ }^{85}$ Az egyösszegü fejadók nem okoznak torzítást, így hatékonysági szempontból jónak mondhatók, de természetesen méltányossági oldalról erősen megkérdőjelezhetőek.
} 
dést hátráltató tényező, hanem inkább úgy interpretálható, hogy a kormányzat fiskális politikájával sokszor túllép azon a szinten, amely még ösztönzi a gazdasági fejlődést.

Már Barro (1991) 3.4. alfejezetben idézett növekedési regressziójában is szerepel a közösségi fogyasztás GDP-aránya a magyarázó változók között, és hatása szignifikánsan negatív mind a hosszú távú növekedési ütem, mind a beruházási ráta szempontjából. Engen és Skinner (1992) 107 ország 1970 és 1985 közötti adatait felhasználva jutott arra a következtetésre, hogy mind a kiadási, mind a bevételi oldal bővülése a gazdasági növekedés ellen hat. Eredményük szerint a költségvetés 10 százalékpontos, kiegyensúlyozott bővítése (az adóbevételek és kiadások 10-10 százalékpontos emelése) 1,4 százalékponttal veti vissza a GDP-növekedés hosszú távú ütemét. Fischer (1993) eredményei szerint a költségvetési egyenleg 1 százalékpontos javulása a növekedési ütem 0,23 százalékpontos emelkedését eredményezi. Easterly és Rebelo (1993) tanulmánya is alátámasztja a költségvetési hiány negatív hatását, de a szerzők külön vizsgálták a kormányzati beruházásokat is, és azt találtak, hogy a telekommunikáció és közlekedés fejlesztésére fordított összegek szignifikánsan javítják a növekedési lehetőségeket. Az OECD (2003) vizsgálata pedig azt mutatta ki, hogy az adóterhek 1 százalékpontos növekedése összesen 0,6-0,7 százalékkal csökkenti az egy före jutó kibocsátást, részben a gazdasági hatékonyság romlásán, részben a tőkefelhalmozás visszavetésén keresztül.

Az államadósság és gazdasági növekedés viszonyában a leghíresebb eredmények Carmen Reinhart és Kenneth Rogoff nevéhez füződnek. Empirikus vizsgálatuk legfontosabb eredménye, hogy a 90 százalék feletti államadósság-GDP arány lényegesen lassabb növekedéssel jár együtt - legyen szó akár fejlett, akár fejlődő országokról. Hozzá kell tenni, hogy nem csak az államadósság számít, hanem a növekedési lehetőségek szempontjából lényeges a külső (magán- és állam-) adósság alakulása is. (Reinhart és Rogoff, 2010)

A közelmúltban magyar szerzők is foglalkoztak a költségvetési politika bizonyos vonatkozásai és a gazdasági növekedés közötti kapcsolattal. Győrffy (2008) a nyugat-európai országok tapasztalatát vizsgálva jutott arra a következtetésre, hogy azok az országok hajtottak végre sikeres kiigazítást, amelyek esetében alapvetően belső elkötelezödés (például a korábbi túlzottan expanzív, populista politikával való felhagyás) vezetett a költségvetés rendbetételéhez, nem pusztán az euró bevezetéséhez szükséges maastrichti kritériumok kényszere. Ezekben az országokban (például 
Svédországban, Finnországban, Írországban vagy éppen Spanyolországban) nem csak, hogy a többieknél tartósabbnak bizonyult az egyenlegjavulás, hanem a gazdasági növekedés terén is jobban teljesítettek. ${ }^{86} \mathrm{Ez}$ persze nem pusztán az elkötelezettségnek köszönhető, hanem annak is, hogy emiatt az elkötelezettség miatt nem elsősorban bevételekkel próbálták betömködni a költségvetés lyukait, hanem hajlandónak bizonyultak a kiadási oldal lefaragására is.

Benczes (2009) is az uniós tagállamok költségvetési kiigazitásainak hatását vizsgálta. A 14 nyugat-európai tagország (az EU-15-ök Luxemburg nélkül) az 19802005 közötti időszakban összesen 61 jelentősnek mondható (a ciklikusan kiigazított elsődleges egyenleget GDP-arányosan legalább másfél százalékponttal javító) kiigazítást hajtott végre. Jóval nagyobb a gazdasági növekedést rövid- és középtávon viszszafogó esetek aránya azon kiigazítások között, amelyek alapvetően a bevételi oldalon igyekeztek stabilizálni a költségvetés helyzetét (majdnem 70 százalék, szemben a kiadásoldali kiigazítások esetén megfigyelhető mintegy 45 százalékkal). Ráadásul a kiadások GDP-arányát nagymértékben csökkentő országok általában hosszú távon is jobb növekedési teljesítményre voltak képesek, mint azok a tagállamok, amelyek nem nagyon nyúltak a kiadási oldalhoz.

A költségvetési politika fegyelmezetlenségére jelenthetnek gyógyírt a különféle fiskális szabályok. Ezek az elöírások az egyszerü numerikus szabályoktól (mint például a GDP-arányos költségvetési hiányt 3 százalékban maximalizáló maastrichti kritérium) az összetettebb (és így rugalmasabb, de nehezebben ellenőrizhető) eljárási szabályokig többféle formát ölthetnek. Mindnek közös jellemzője viszont, hogy igyekszik szűkíteni a költségvetési politika mozgásterét és így meggátolni a túlköltekezést. Ha a költekezés összességében rontja a növekedési lehetőségeket, akkor a fiskális szabályok hosszabb távon a gazdasági fejlődést is elősegíthetik. Ezt is vizsgálta Kopits (2007), és arra a következtetésre jutott, hogy a költségvetési szabályokat

\footnotetext{
${ }^{86}$ A pénzügyi válság során nagyon heterogén volt ezeknek az országoknak a teljesítménye. A 2009-es visszaesés tekintetében nagy eltérések voltak közöttük (Spanyolország -3,6 százalék, Finnország -8,3 százalék), az azonban közös, hogy a kezdeti kilábalás után 2012-ben az eurózóna sok országához hasonlóan mind a négy ország újra recesszióba fordult. Fiskális szempontból pedig két párra oszthatók: Írországban és Spanyolországban a válság hatására (részben az adóbevételek ciklikus visszaesése miatt, részben a pénzügyi szektorban szükségessé váló komoly intézkedések eredményeként) megugrott a költségvetési hiány, és az adósságráta a többszörösére növekedett. Ezzel szemben Finnország és Svédország a recesszió éveiben is törekedett a költségvetés egyensúly-közeli állapotban tartására, így a korábbi többletek csak mérsékelt hiányba fordultak a visszaesés hatására, és a GDP-arányos államadósság növekedési üteme is kezelhetőnek mondható. (Eurostat, 2016)
} 
alkalmazó országok nagyobb és kevésbé ingadozó növekedési ütemet értek el, bár azt mindenképpen meg kell jegyezni, hogy a vizsgált időszak meglehetősen rövid.

A költségvetés bevételi oldalának szerkezete is hatással lehet a gazdasági növekedésre. Az adók különböző mértékben torzítják a gazdasági döntéseket, így eltérő mértékü hatékonyságveszteséget eredményeznek. Erős (2008) magyar adatokon vizsgálta az adóstruktúra és a gazdasági növekedés kapcsolatát. Az elméletnek többékevésbé megfelelően azt találta, hogy a torzító adók (jövedelem- és nyereségadók, társadalombiztosítási hozzájárulás) arányának növekedése negatív, míg a kevésbé torzító fogyasztási adók arányának növekedése pozitív hatással van az egy före jutó reál-GDP bővülésének ütemére. Az összes bevétel GDP-aránya és a gazdasági növekedés között is negatív kapcsolatot mutatott ki a szerző.

Mindezek a vizsgálatok egy irányba mutatnak: a fegyelmezett makrogazdasági politika alapvetően elősegíti a gazdasági növekedést. Természetesen lehetnek olyan országok és időszakok, amelyekben nagy költségvetési deficit társul az erőteljes növekedéshez, de ez az állapot hosszú távon nem fenntartható. A hosszú távú növekedéshez fegyelmezett gazdaságpolitika szükséges.

\subsection{Költségvetési politika és növekedés az Európai Unióban}

Mielőtt rátérnénk a kelet-közép-európai országok költségvetési politikájának néhány vonatkozására, érdemes megvizsgálni, hogyan alakul a költségvetési és növekedési adatok kapcsolata az Európai Unióban. Az előző alfejezetben elmondottak értelmében a következőket várhatjuk: a nagyobb jövedelem-újraelosztás, a rosszabb egyenlegpozíció, illetve a magasabb GDP-arányos államadósság alacsonyabb átlagos növekedési ütemmel jár együtt. Az adatok alapvetően mindhárom várakozást megerősítik.

Az újraelosztás mértéke és a költségvetési egyenleg tekintetében a pénzügyi válságot megelőző időszakot vizsgáltam. Ennek magyarázata, hogy a kiadások és egyenleg átlagos értékeit használtam, amelyeket egyes országokban jelentősen elmozdított az, hogy a válság hatására akár csak egy-egy évben kiugró kiadási szintet és deficitet produkáltak részben a nagymértékű gazdasági növekedés, részben az egyszeri tételek (bankmentések, államosítások stb.) eredményeként. ${ }^{87}$ Másrésztől

\footnotetext{
${ }^{87}$ Az adatválasztás kapcsán az a dilemma merül fel, amit a 3.4. alfejezetben említettem a növekedési regressziókkal kapcsolatban: az átlagos kiadási szint és egyenleg esetében az endogenitás okoz problémát, kizárólag a kiinduló érték használata esetén viszont a magyarázóerő lehet korlátozott.
} 
arra voltam kíváncsi, hogy a válságot megelőző „,békés” növekedési periódusban hogyan alakult a költségvetési és növekedési adatok kapcsolata.

12. ábra: Jövedelem-újraelosztási ráta és gazdasági növekedés az Európai Unió országaiban

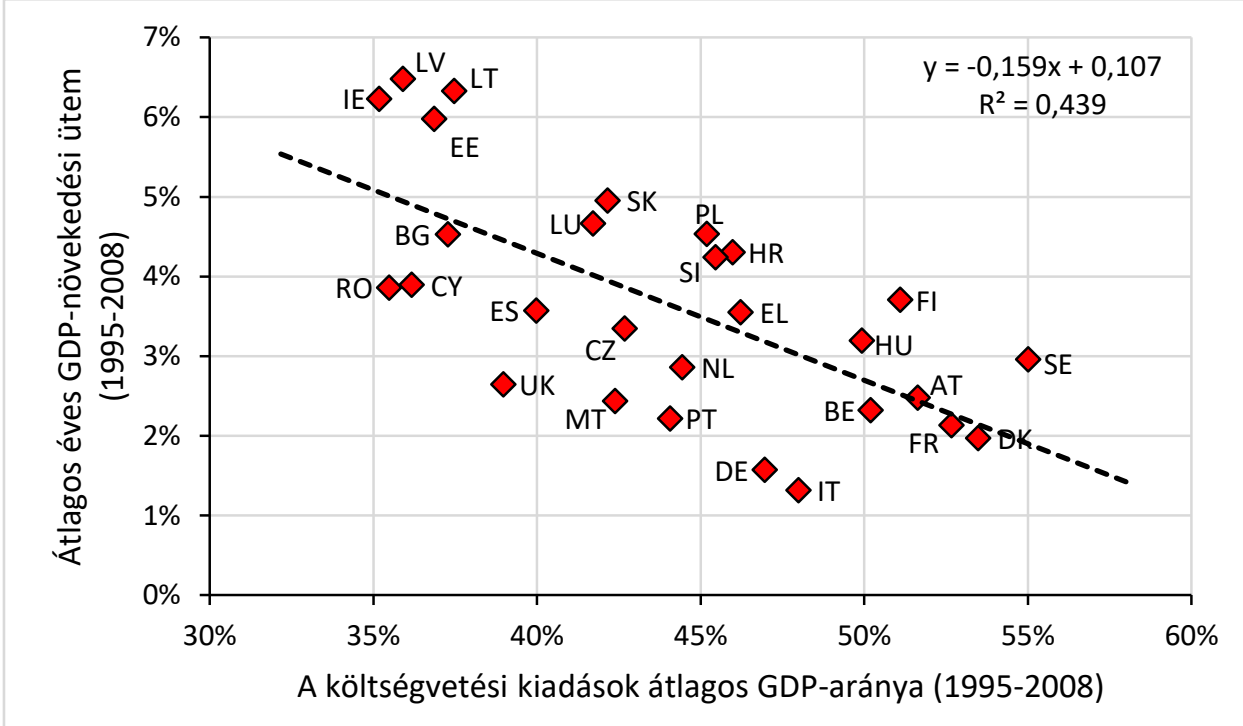

Saját szerkesztés az Eurostat (2016) adatai alapján

Megjegyzés: Adathiány miatt négy ország esetében az átlagok rövidebb időszakra vonatkoznak: Bulgária 1997-2008, Szlovákia 1998-2008, Horvátország 2000-2008, Málta 2001-2008. Jelmagyarázat: AT: Ausztria, BE: Belgium, BG: Bulgária, CY: Ciprus, CZ: Csehország, DE: Németország, DK: Dánia, EE: Észtország, EL: Görögország, ES: Spanyolország, FI: Finnország, FR: Franciaország, HR: Horvátország, HU: Magyarország, IE: Írország, IT: Olaszország, LT: Litvánia, LU: Luxemburg, LV: Lettország, MT: Málta, NL: Hollandia, PL: Lengyelország, PT: Portugália, RO: Románia, SE: Svédország, SI: Szlovénia, SK: Szlovákia, UK: Egyesült Királyság

A 12. ábra a jövedelem-újraelosztási ráta és az átlagos növekedési ütem közötti negatív kapcsolatot jeleníti meg. A leggyorsabban növekvő országok (a balti államok és Írország) az EU átlagánál lényegesen, mintegy 10 százalékponttal alacsonyabb kiadási aránnyal rendelkeztek a vizsgált időszakból. Ekkora differencia átlagosan mintegy 1,6 százalékpontos növekedési ütemtöbblettel járt együtt a minta egészében. Látható, hogy ez a négy ország a regressziós egyenes felett helyezkedik el, vagyis még gyorsabb növekedést ért el - aminek elsődleges magyarázója a jelentős működőtőke-beáramlás, a visszafogott állami szerepvállalás ennek hatását erősítette. Fontos azt is hozzátenni, hogy a negatív (igaz, enyhébb) kapcsolat akkor is kirajzolódik, ha e négy országot kivesszük a mintából. Ez tehát alátámasztani látszik azt, hogy az EU több országában is magasabb lehet a költségvetési újraelosztás, mint ami növekedési szempontból optimális lenne, de lényeges, hogy a költségvetés puszta 
mérete mellett a kiadásokból finanszírozott állami szolgáltatások, fejlesztési programok minősége legalább ilyen fontos (mennyire hatékonyan költi el a pénzt a kormányzat, mekkora a korrupció stb.).

\section{3. ábra: Költségvetési egyenleg és gazdasági növekedés az Európai Unió országaiban $\mathbf{I}$.}

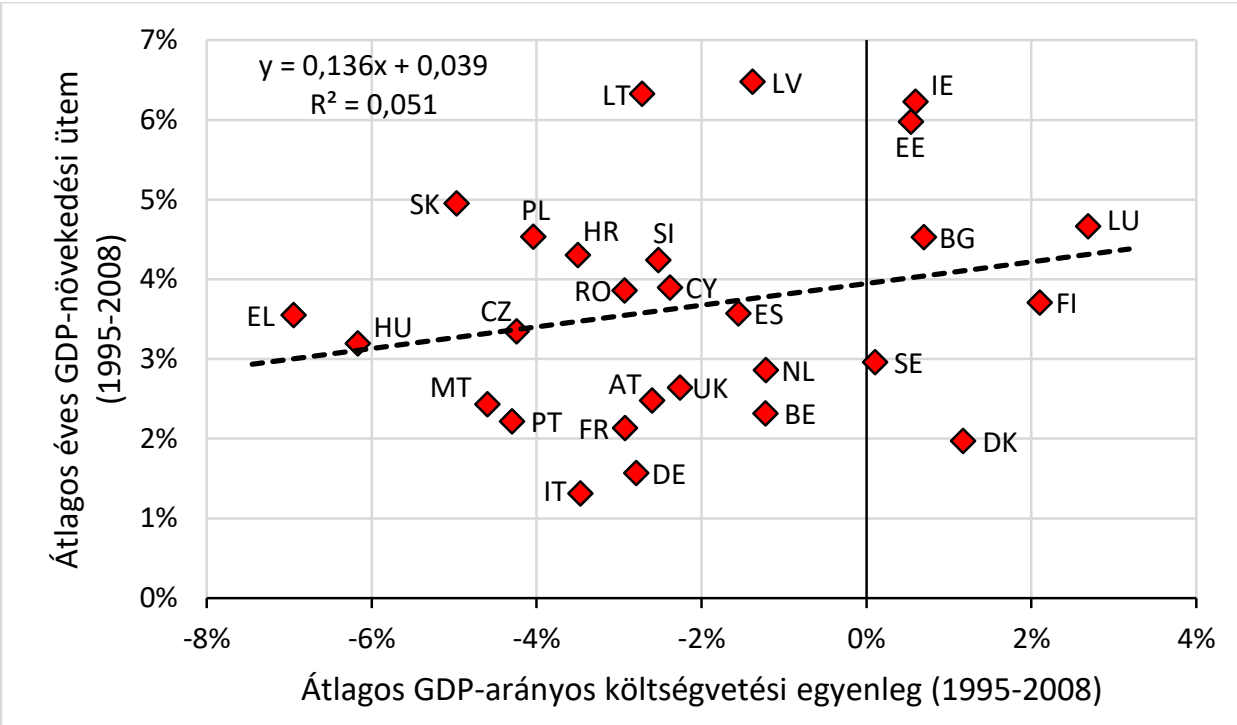

Saját szerkesztés az Eurostat (2016) adatai alapján

Megjegyzés: Adathiány miatt négy ország esetében az átlagok rövidebb időszakra vonatkoznak: Bulgária 1997-2008, Szlovákia 1998-2008, Horvátország 2000-2008, Málta 2001-2008. Jelmagyarázat: AT: Ausztria, BE: Belgium, BG: Bulgária, CY: Ciprus, CZ: Csehország, DE: Németország, DK: Dánia, EE: Észtország, EL: Görögország, ES: Spanyolország, FI: Finnország, FR: Franciaország, HR: Horvátország, HU: Magyarország, IE: Írország, IT: Olaszország, LT: Litvánia, LU: Luxemburg, LV: Lettország, MT: Málta, NL: Hollandia, PL: Lengyelország, PT: Portugália, RO: Románia, SE: Svédország, SI: Szlovénia, SK: Szlovákia, UK: Egyesült Királyság

A 13. ábra a költségvetési egyenleg és növekedési ütem összefüggését vizsgálja. Egy enyhe pozitív kapcsolat megfigyelhető, de látható, hogy a regressziós egyenes nagyon gyengén illeszkedik az adatokra. Ennek elsősorban az az oka, hogy az alacsonyabb GDP-vel rendelkező kelet-közép-európai országok általában gyorsabban tudtak növekedni, mint a hasonló egyenlegpozíciójú, fejlettebb államok (feltételes konvergencia). ${ }^{88}$

${ }^{88}$ A feltételes konvergencia természetesen a 12. ábra kapcsán is érezteti hatását. Itt azért jelentkezik másképpen, mert a kelet- és nyugat-európai országok átlagos egyenlegpozíciója között nincs érdemi különbség. Ugyanez nem volt elmondható a jövedelem-újraelosztási rátára: a volt szocialista EUtagállamokban átlagosan kisebb a költségvetési kiadások GDP-aránya. 


\section{4. ábra: Költségvetési egyenleg és gazdasági növekedés az Európai Unió}

országaiban II.
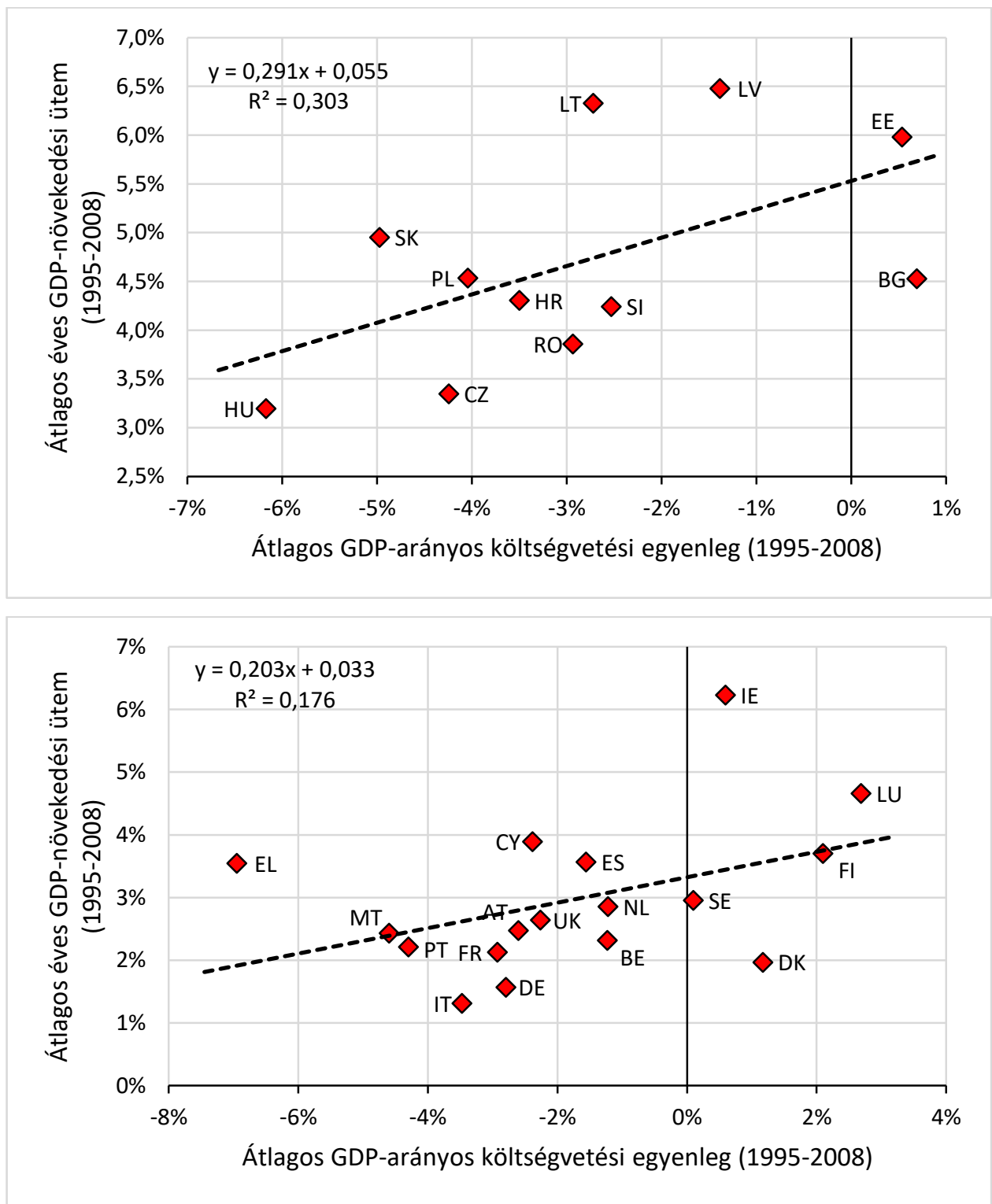

Saját szerkesztés az Eurostat (2016) adatai alapján

Megjegyzés: Adathiány miatt négy ország esetében az átlagok rövidebb időszakra vonatkoznak: Bulgária 1997-2008, Szlovákia 1998-2008, Horvátország 2000-2008, Málta 2001-2008. Jelmagyarázat: AT: Ausztria, BE: Belgium, BG: Bulgária, CY: Ciprus, CZ: Csehország, DE: Németország, DK: Dánia, EE: Észtország, EL: Görögország, ES: Spanyolország, FI: Finnország, FR: Franciaország, HR: Horvátország, HU: Magyarország, IE: Írország, IT: Olaszország, LT: Litvánia, LU: Luxemburg, LV: Lettország, MT: Málta, NL: Hollandia, PL: Lengyelország, PT: Portugália, RO: Románia, SE: Svédország, SI: Szlovénia, SK: Szlovákia, UK: Egyesült Királyság

Ha ennek megfelelően kettébontjuk a mintát (14. ábra), akkor azt láthatjuk, hogy mindkét országcsoportban jobb növekedési teljesítményt értek el azok az országok, ahol jobb volt a költségvetés átlagos pozíciója. 1 százalékponttal jobb egyenleg a volt szocialista országok esetében átlagosan 0,3 százalékponttal, Nyugat- 
Európában átlagosan 0,2 százalékponttal magasabb éves növekedési ütemmel járt együtt. A regresszió magyarázóereje ebben az esetben is alacsony, egyrészt azért, mert egy-egy részmintában kevés megfigyelés van, másrészt vannak kiugró, a trendtől távol eső adatok is (például Görögország vagy Írország a nyugat-európai országok között).

\section{5. ábra: Államadósság és gazdasági növekedés az Európai Unió országaiban}

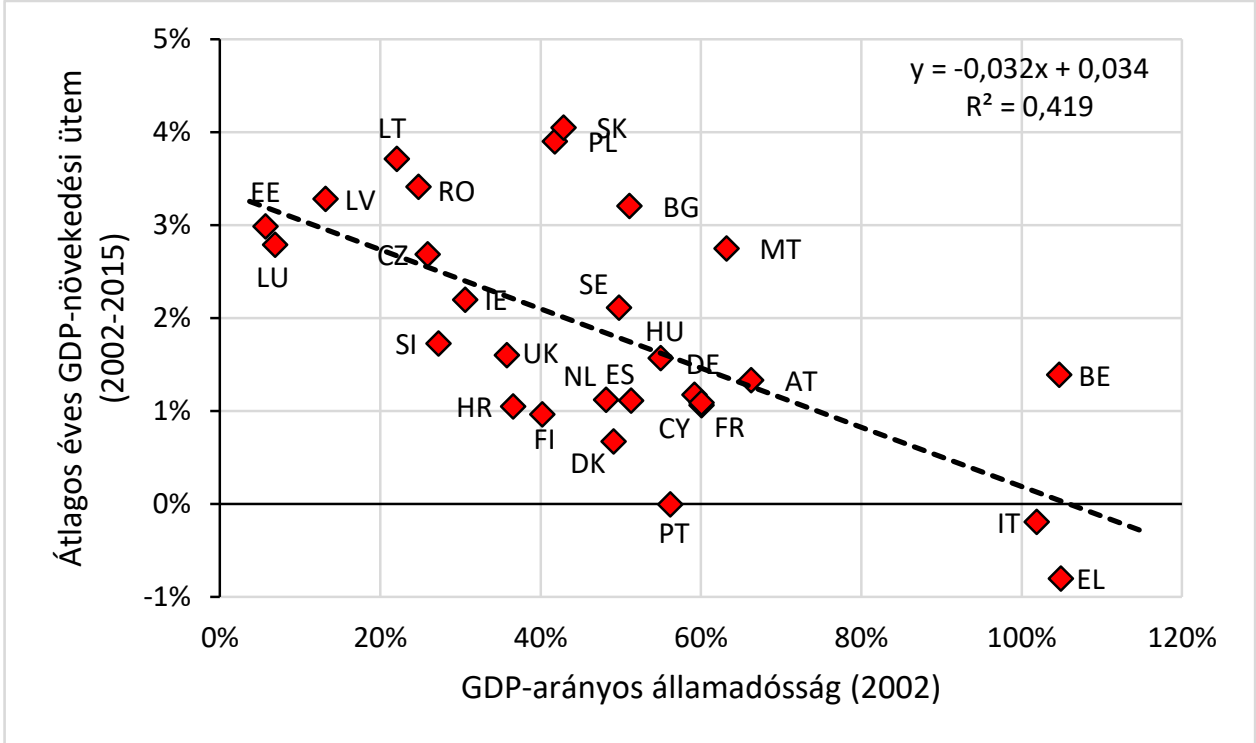

Saját szerkesztés az Eurostat (2016) adatai alapján

Megjegyzés: Írország 2015-ös GDP-je egy 2016. nyári adatrevízió eredményeként kiugróan magas lett (több mint 26 százalékkal nagyobb a 2014-es értéknél), ezért Írország esetében a 2002-2014 közötti átlagos növekedési ütem szerepel az ábrán. Jelmagyarázat: AT: Ausztria, BE: Belgium, BG: Bulgária, CY: Ciprus, CZ: Csehország, DE: Németország, DK: Dánia, EE: Észtország, EL: Görögország, ES: Spanyolország, FI: Finnország, FR: Franciaország, HR: Horvátország, HU: Magyarország, IE: Írország, IT: Olaszország, LT: Litvánia, LU: Luxemburg, LV: Lettország, MT: Málta, NL: Hollandia, PL: Lengyelország, PT: Portugália, RO: Románia, SE: Svédország, SI: Szlovénia, SK: Szlovákia, UK: Egyesült Királyság

Az államadósságra vonatkozóan az előzőektől némileg eltérő megközelítést alkalmaztam. Egyrészt - állományváltozóról lévén szó - itt relevánsabbnak éreztem a kezdeti érték (örökölt adósság) alkalmazását az átlag helyett. Másrészt a vizsgált időszak is különbözik a másik két változó esetén használttól. Az Eurostat (2016) adatbázisában 2002 az első év, amelyre minden tagország államadósság-adata elérhető, így ezt az évet választottam kiindulópontnak. Emellett az is fontos, hogy a túlzott eladósodottság nem csak fékezheti a növekedést normál körülmények között (például a kamatkiadások vagy a bizonytalanság miatt csökkenő beruházási hajlandóság ré- 
vén), hanem egy recesszió esetén nagyon erősen befolyásolja, mennyire képes beavatkozni a kormányzat a visszaesés tompítása érdekében. Magyarország esetében ez kifejezetten lényeges elem volt 2008-2009-ben: a korábbi költségvetési túlköltekezés és a felhalmozott adósságállomány miatt a kormányzat nem tudta élénkíteni a receszszióba kerülő gazdaságot, hanem pro-ciklikus fiskális politikára kényszerült.

Ezért szerepel a 15. ábra függőleges tengelyén a pénzügyi válságot is felölelő 2002-2015-ös időszak átlagos éves növekedési üteme. A várakozásoknak megfelelöen negatív kapcsolatot figyelhetünk meg az örökölt államadósság és a GDPnövekedési ütem között: 10 százalékponttal magasabb adósságráta átlagosan 0,3 százalékponttal lassabb növekedési ütemmel járt együtt a vizsgált időszakban.

\section{4. Újraelosztás, költségvetési egyenleg és államadósság Kelet-Közép-Európa országaiban}

A következőkben néhány alapvető, az előző alfejezetben is vizsgált szempont szerint áttekintem a kelet-közép-európai országok fiskális helyzetét. Három ilyen szempontot veszek sorra: a költségvetés méretét, egyensúlyi helyzetét, illetve az államadósság alakulását.

A költségvetés méretét legegyszerübben a jövedelem-újraelosztási ráta (költségvetési kiadások GDP-aránya) és a jövedelemcentralizációs ráta (költségvetési bevételek GDP-aránya) segítségével ragadhatjuk meg. Ezek természetesen nem fedik le az állam gazdasági szerepvállalásának minden vetületét, de azt megmutatják, hogy az adott időszak megtermelt jövedelmeinek mekkora hányada folyik keresztül a büdzsén, így egy fontos szempontból jellemzik, hogy az állam mennyire aktívan nyúl bele a gazdasági folyamatokba. A két mutató általában együtt mozog, hogy mennyire szorosan, az a költségvetés egyensúlyi helyzetét jellemzi, hiszen a kettő különbsége nem más, mint a GDP-arányos költségvetési egyenleg.

A 16. ábrán látható a jövedelem-újraelosztási ráta alakulása a térség országaiban. Vannak egyszeri kiugró értékek, amelyek torzítják az összképet (ilyen például a 2013-as szlovén bankmentés hatása), de ezzel együtt is kirajzolódnak különbségek az országok között. A legnagyobb jövedelem-újraelosztási ráta Magyarországot jellemzi, tartósan 50 százalék körül alakul az érték, ehhez zárkózott fel az utóbbi időben Szlovénia és kisebb mértékben Horvátország is. A magyar adatokban jól megfigyelhető egy hullámzás, melynek csúcsai az 1998-as, 2002-es és 2006-os választási évek- 
re esnek, vagyis jól kimutatható a választásokra időzített költekezés hatása. ${ }^{89}$ Egy következő csoportot alkot Csehország és Lengyelország, akik esetében gyakorlatilag az 1990-es évek vége óta 40-45 százalék között alakul a kiadások GDP-aránya.

\section{6. ábra: A költségvetési kiadások GDP-arányának alakulása a kelet-közép-európai országokban}

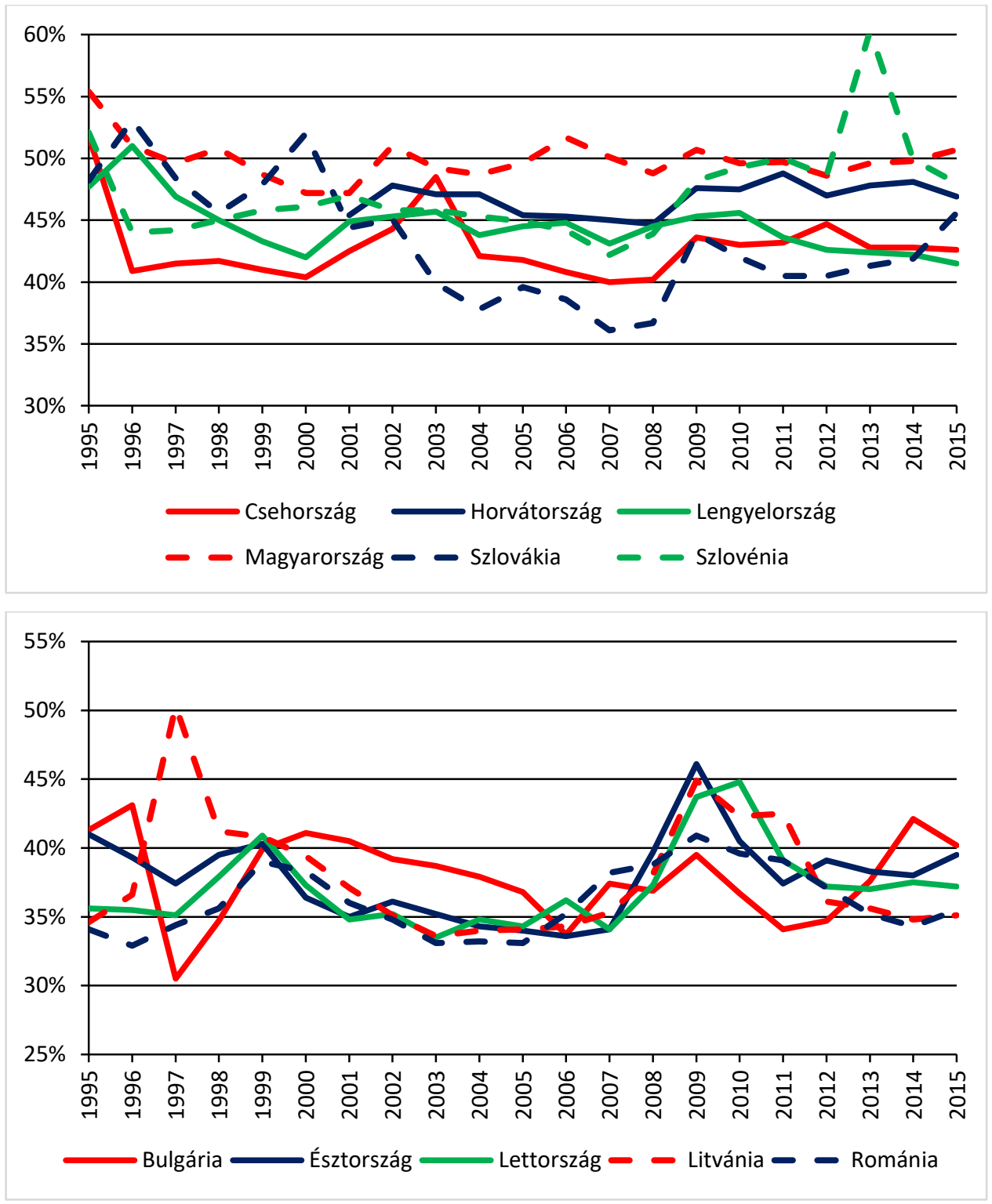

Saját szerkesztés az Eurostat (2016) adatai alapján

Az utóbbi évek alapján e csoportba sorolható Szlovákia is, de a szlovák adatok legérdekesebb vonatkozása nem ez, hanem a jövedelem-újraelosztási ráta 20002008 közötti csökkenése (mintegy 52 százalékról 36 százalékra), ami ilyen rövid idő

${ }^{89}$ A politikai költségvetési ciklusokkal kapcsolatban lásd az 5.6. alfejezetet. 
alatt mindenképpen figyelemre méltó. Ez a Dzurinda-kormányzat tudatos gazdaságpolitikájának eredménye, melynek kimondott célja volt az ország versenyképességének növelése az állami szerepvállalás mérséklésén keresztül. ${ }^{90}$ Ahogy a 4.1 és 4.3. alfejezetekben láttuk, a gazdasági növekedés tekintetében ez mindenképpen sikeresnek bizonyult, hiszen a GDP gyors ütemü bővülését segítette elő, illetve a foglalkoztatottsági ráta is 5,5 százalékponttal emelkedett 2000-2008 között. Azonban természetesen vannak árnyoldalai is: a jóléti kiadások visszafogása (a szociális védelemre - benne nyugdíjellátásra - fordított kiadások a GDP 14,7 százalékáról 10,3 százalékra estek vissza) a jövedelmi különbségek növekedéséhez vezetett.

Az ábra alsó felén szereplő öt ország az ezredforduló óta nagyon hasonló pályán halad a költségvetés méretét illetően. A 2000-es évtized gyors növekedést produkáló időszakában az újraelosztási ráta mindenhol mintegy 5 százalékponttal mérséklődött azáltal, hogy a versenyképesség fenntartása érdekében a kiadásokat a kormányzatok igyekeztek féken tartani, és noha reálértéken nőttek, ennek sebessége elmaradt a GDP-bővülés ütemétől. A válság idején viszont ennek ellenkezője figyelhető meg: Bulgáriában és Romániában 5 százalékponttal, a három balti államban 10 százalékponttal emelkedett a költségvetési kiadások GDP-aránya, hiszen a gazdaságot erőteljes recesszió sújtotta, míg a kiadások ezt nem (Bulgária és Románia) vagy csak kisebb mértékben (balti államok) követték. A gazdasági visszaesés hatására nemcsak ebben az öt országban, hanem mindenhol megemelkedett a jövedelemújraelosztási ráta, a legkevésbé Magyarországon, ahol - mint az előző alfejezet végén is utaltam rá - a kormányzat a korábbi évek fenntarthatatlan költségvetési politikájának áraként kénytelen volt pro-ciklikus, megszorító politikát folytatni a válság éveiben.

A 17. ábrán a jövedelemcentralizációs ráta alakulása látható, ami szintén érdekes tanulságokkal szolgál, noha a tendenciák sok tekintetben hasonlóak a kiadásokkal kapcsolatban elmondottakhoz. Magyarországot e tekintetben is Szlovénia és Horvátország követi, majd némileg alacsonyabb jövedelemcentralizációs rátával Csehország és Lengyelország. Hazánkban a 2006-os választásokat követően meginduló fiskális konszolidáció óta egyértelmüen növekvő trendet mutat a bevételek GDP-aránya (42,3 százalékról 48,7 százalékra), miközben a kiadásoké gyakorlatilag változatlan. Ez nagymértékű egyenlegjavulást jelent, ami önmagában egyértelműen

\footnotetext{
${ }^{90}$ A szlovák strukturális reform bemutatását, elemzését lásd Győrffy (2014) tanulmányában.
} 
kedvező, azonban ennek a javulásnak az összetétele már nem ideális. A gazdasági növekedés szempontjából ugyanis lényegesen szerencsésebb, ha az adóterhelés növelése helyett a kiadásokat sikerül lefaragni.

17. ábra: A költségvetési bevételek GDP-arányának alakulása a kelet-közép-európai országokban

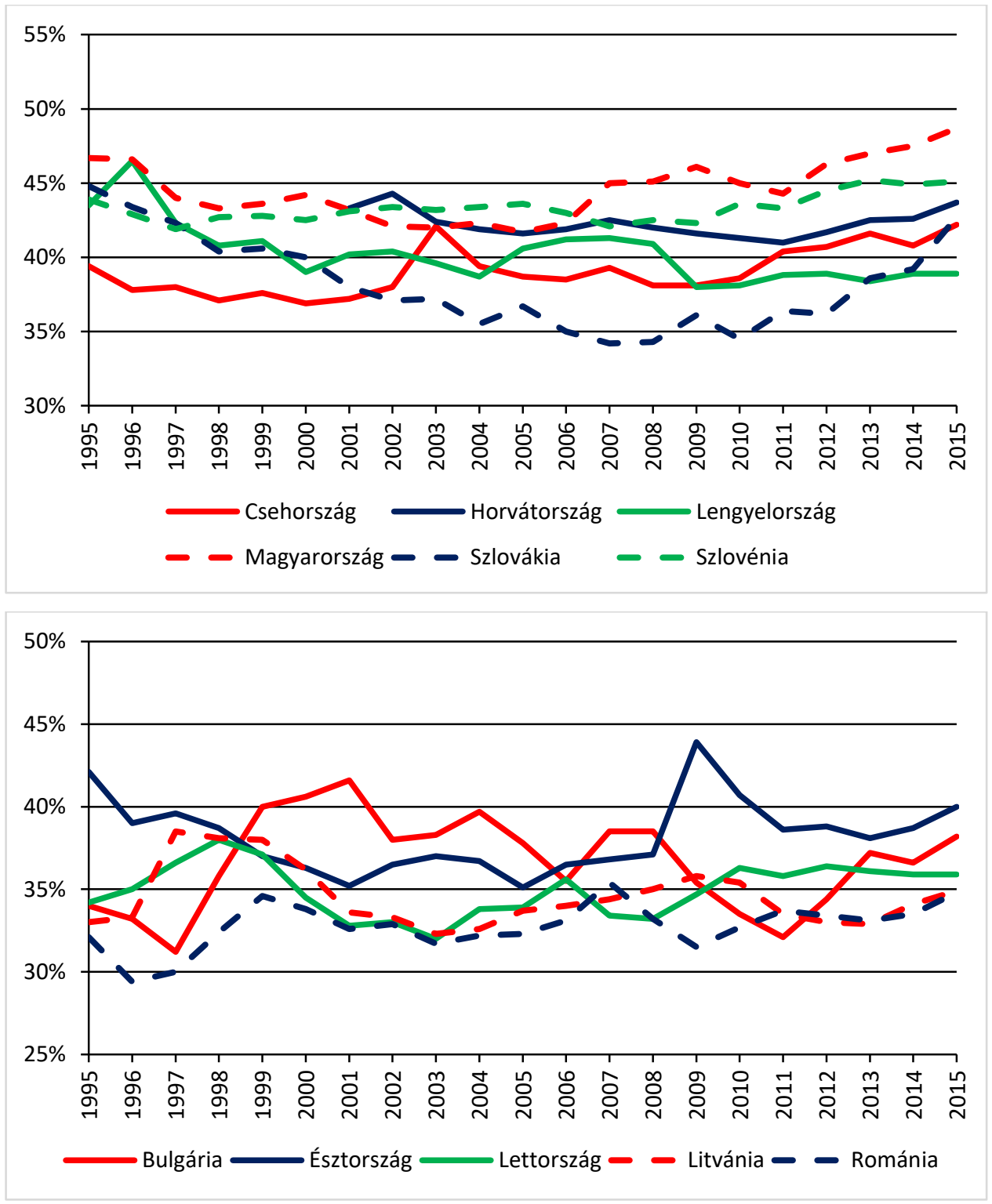

Saját szerkesztés az Eurostat (2016) adatai alapján

Szlovákiában a bevételek tekintetében is hasonló változások zajlottak, mint a jövedelem-újraelosztási ráta esetében, azonban fokozatosabban. Ennek oka, hogy a bevételek már az 1990-es években csökkenésnek indultak, miközben a kiadások GDP-aránya 1998-2000 között még jelentősen növekedett, így teljes mértékben fel- 
borult a fiskális egyensúly, vagyis a költségvetés méretének csökkentése mellett egyenlegjavításra is szükség volt. Ez pedig a kiadásoknak a bevételeknél nagyobb arányú mérséklését tette szükségessé.

Az ábra második részén szereplő öt ország a jövedelemcentralizáció tekintetében is alacsonyabb értékeket mutat, de heterogénabb kép rajzolódik ki, mint a kiadások esetében. Bulgária és Észtország ugyanis tartósan magasabb bevétel-GDP arányt produkál, mint a másik három ország. Ennek hatása a költségvetési egyenleg és államadósság alakulásában is meglátszik, amire lentebb visszatérek.

Még egy dolgot fontos kiemelni a 16-17. ábra kapcsán: a pénzügyi válság hatása erősebben kirajzolódik a kiadások, mint a bevételek GDP-arányán, a nevező csökkenése egyedül Észtországban vezetett a jövedelemcentralizációs ráta megugrásához. Ennek az az oka, hogy a gazdasági visszaesés hatására az adóbevételek automatikusan csökkennek: az alacsonyabb átlagjövedelem, kevesebb nyereség, kisebb fogyasztás jelentősen visszafogja a jövedelemadóból, nyereségadóból, forgalmi adóból származó bevételeket. ${ }^{91} \mathrm{Az}$ EU országaiban a büdzsé bevételi oldalának döntő többsége (80-90 százaléka) adókból származik, így ez a hatás értelemszerüen a teljes bevételen is meglátszik. Vagyis a bevételek csökkenése leköveti a gazdasági visszaesést, így nem növekszik a tört értéke. A kiadások döntő többsége esetében nincs hasonló automatikus alkalmazkodás, ezért (kiegészítve a válság enyhítését célzó diszkrecionális kiadási döntésekkel) következik a jövedelem-újraelosztási ráta megugrása a recesszióból.

Ahogy fentebb már említettem, a jövedelemcentralizációs és jövedelemújraelosztási ráták különbsége adja a GDP-arányos költségvetési egyenleget. Ez szerepel a 18. ábrán. Az előzőekben elmondottakhoz hasonló jellegzetességek ezen is megfigyelhetők: a 2000-es évtized kiemelkedően rossz magyar fiskális helyzete, illetve a választási évek kiugró hiányadatai, a szlovák költségvetési politika átformálódása ugyanebben az időszakban, az észt és bolgár költségvetési többlet, valamint a pénzügyi válság nyomán bekövetkező jelentős egyenlegromlás a régió szinte összes országában.

\footnotetext{
${ }^{91}$ Ezt az automatikus hatást kiegészíthetik élénkítő célzatú adócsökkentések is.
} 


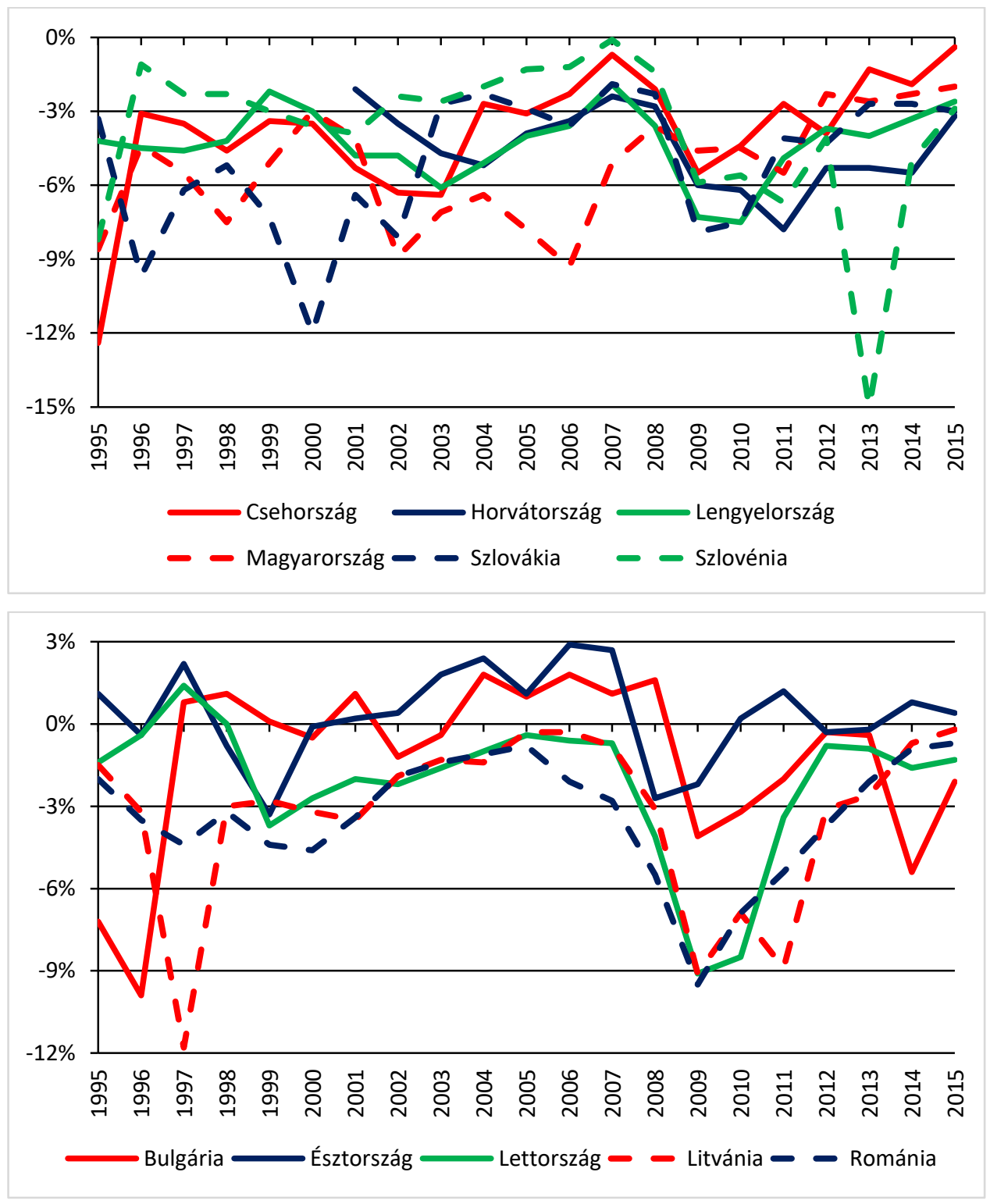

Saját szerkesztés az Eurostat (2016) adatai alapján

E tekintetben érdemes kiemelni az Észtország és a másik két balti állam között megfigyelhető különbségeket. A recesszió során a kiadások terén igyekeztek elkerülni a megszorítást, így a jövedelem-újraelosztási ráta megközelítőleg azonos mértékben ugrott meg mindhárom országban. Lettországban és Litvániában ez egyértelműen az egyenleg nagymértékü romlásában csapódott le. Ezzel szemben Észtországban a kiadás-GDP arány növekedését a jövedelemcentralizációs ráta (ugyan kisebb mértékü, de szintén) jelentős emelkedése kísérte. Ez nagyrészt a társadalombiztosítási járulék-bevételek, valamint az áfa és a jövedéki adók megemelésének köszönhető. Így a költségvetési egyenleget 2008-2009-ben is sikerült a háromszázalé- 
kos hiányon belül tartani, azóta pedig visszatért az egyensúlyi helyzet közelébe. Ennek egyik fö magyarázata, hogy ez az időszak pontosan egybeesett az euró észtországi bevezetését megelőző értékelési szakasszal, így fontos volt, hogy az ország meg tudjon felelni a költségvetési hiányra vonatkozó maastrichti kritériumnak.

19. ábra: A GDP-arányos államadósság alakulása a kelet-közép-európai országokban

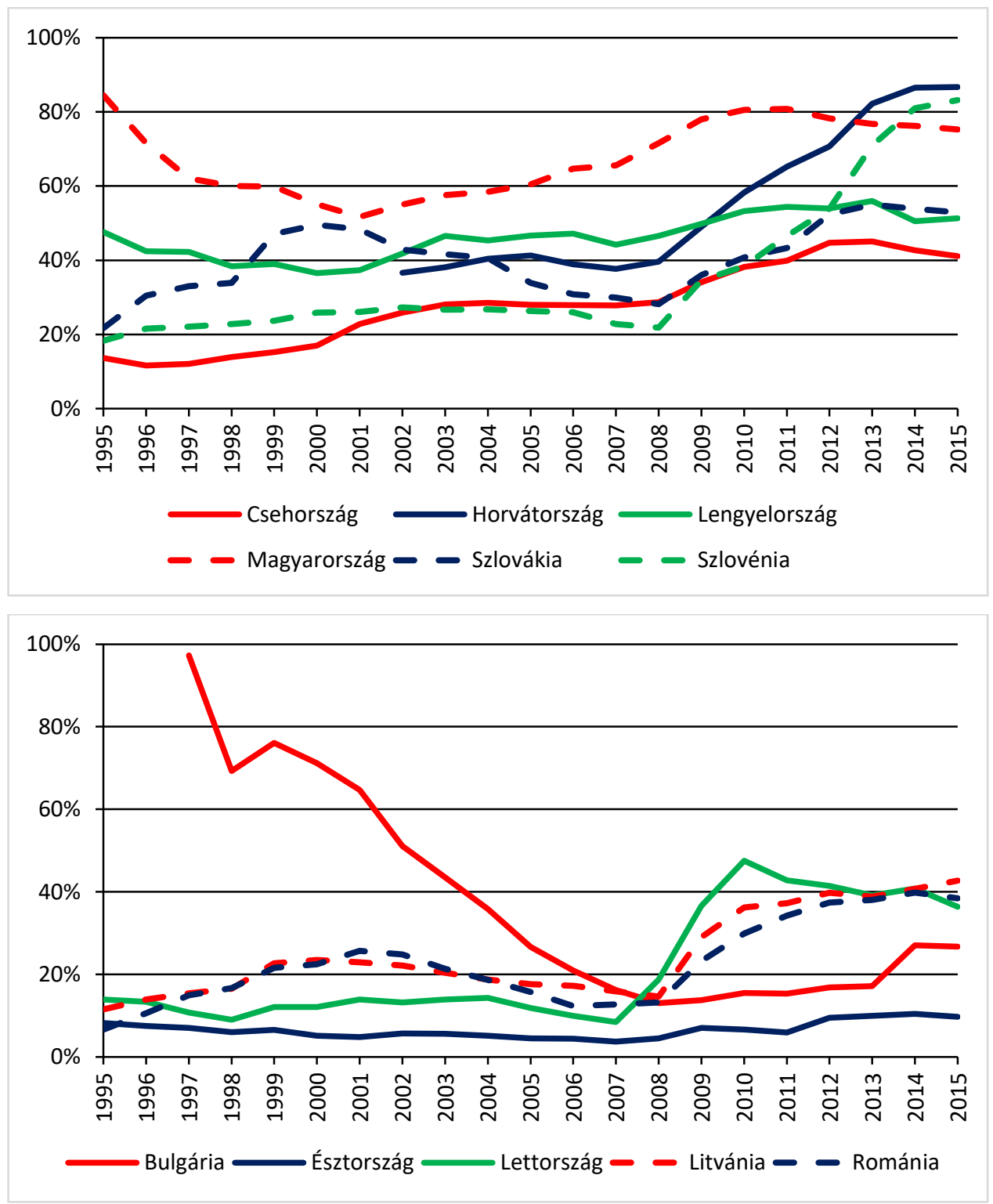

Saját szerkesztés az Eurostat (2016) adatai alapján

Végül a 19. ábrán az államadósság-ráta alakulása látható. A térségben tartósan Magyarország volt a leginkább eladósodva. A rendszerváltozáskor örökölt adósságállományt egyrészt a privatizációból befolyt összegeknek, másrészt a Bokroscsomag kiigazító lépéseinek, harmadrészt a meginduló gazdasági növekedésnek kö- 
szönhetően sikerült jelentős mértékben leépíteni az ezredfordulóig. 2001-től kezdődően a fiskális politika lazulása eredményeként újra növekedésnek indult az adósságráta, ami egyedülálló jelenség volt ekkoriban a régióban. A költségvetési politika már 2006 után meginduló, majd 2009-2010-ben új lendületet kapó - megszigorodásával viszont sikerült a növekedési ütemet lefékezni, és az utóbbi években enyhén csökkenő pályára állt a GDP-arányos államadósság.

Részben ennek köszönhető, hogy ma már nem a magyar állam a legeladósodottabb a térségben - jelentősebb részben viszont annak, hogy a válság hatására leromló fiskális helyzet és tartós gazdasági visszaesés eredményeként Horvátországban 49 százalékponttal, Szlovéniában mintegy 60 százalékponttal ugrott meg az adósságráta 2007-2015 között. Szlovéniában ez a GDP-arányos államadósság négyszeresre növekedését jelentette, ilyen robbanásszerü növekedéssel Európa nyugati felén a válság által más módon, de szintén nagyon súlyosan érintett Írország szembesült.

Szlovákiában az adósságállomány alakulásán is látható a 2000-es évek reformintézkedéseinek sikere: 20 százalékponttal sikerült mérsékelni az államadósságGDP arányt ${ }^{92}$, a válság nyomán viszont újra növekedésnek indult, és jelenleg már meghaladja a 2000-es szintet is. Hasonló, de még élesebb tendencia látszódik Lettországban, Litvániában és Romániában is. Az észt helyzet különbözősége itt is megfigyelhető: az adóbevételek növelésével sikerült elejét venni a költségvetési helyzet jelentős és tartós romlásának, aminek eredményeként az adósságrátát is sikerült alacsonyan tartani. Észtország a megelőző években is jobb egyenleget ért el a másik két balti államnál, ennek eredményeként a teljes időszakban a régió (és az egész Európai Unió) legalacsonyabb adósság-GDP arányával büszkélkedhetett. ${ }^{93}$ Érdemes azonban újra megemlíteni, hogy amint azt Kutasi (2014) kifejti, a fiskális politika fegyelmezettsége nem jelenti feltétlenül a populizmus teljes hiányát, hiszen passzív formában ez jelentkezett a külső egyensúlytalanságok kiigazításának elmaradásában.

\subsection{A kelet-közép-európai országok adórendszereinek jellemző vonásai}

A költségvetés adóbevételeit többféleképpen csoportosíthatjuk. Az egyik leggyakrabban alkalmazott bontás a közvetlen és közvetett adók szerinti különbségtétel. Előbbi csoportba tartoznak a különféle jövedelmi és vagyoni adók, míg utóbbiba a

\footnotetext{
92 A magyar és a szlovák eset összevetéséröl lásd Oblath (2014a, pp. 16-17) tanulmányát.

${ }^{93}$ Míg a fegyelmezett fiskális politika, a gyakran többletet mutató költségvetés Észtországban a minimális eladósodottság állapotának fenntartását szolgálta, addig a más helyzetből induló Bulgáriában az örökölt hatalmas adósságállomány rendkívül gyors ütemü leépítését.
} 
fogyasztáshoz kapcsolódó adóterhek, amelyek esetében elválik egymástól a jog szerinti fizetési kötelezettség és a tényleges adóteher (ez tulajdonképpen az adóteher áthárítását jelenti). Mivel a közvetett adók esetében nem jellemző a progresszivitás alkalmazása, ezért azokban az országokban, ahol ezek súlya nagyobb, kevésbé erős a jövedelmek adórendszeren keresztül történő újraelosztása, arra ugyanis inkább a (progresszív) közvetlen adók adhatnak lehetőséget. Az Európai Unióban a 11 keletközép-európai ország esetében a legalacsonyabb a közvetlen adók aránya a teljes adóbevételen belül: 17,1-27,6 százalék az arányuk, miközben az EU-átlag 33,4 százalék. ${ }^{94}$ (Eurostat, 2014) Ez tehát azt mutatja, hogy a térségben kevésbé jelentős a jövedelem-eloszlás adórendszeren keresztül történő korrekciója, ami összhangban van azzal is, hogy a régiós tagállamok többsége lineáris személyi jövedelemadórendszert alkalmaz.

\section{0. ábra: Az adóbevételek közgazdasági funkciók szerinti bontása a GDP százalékában}

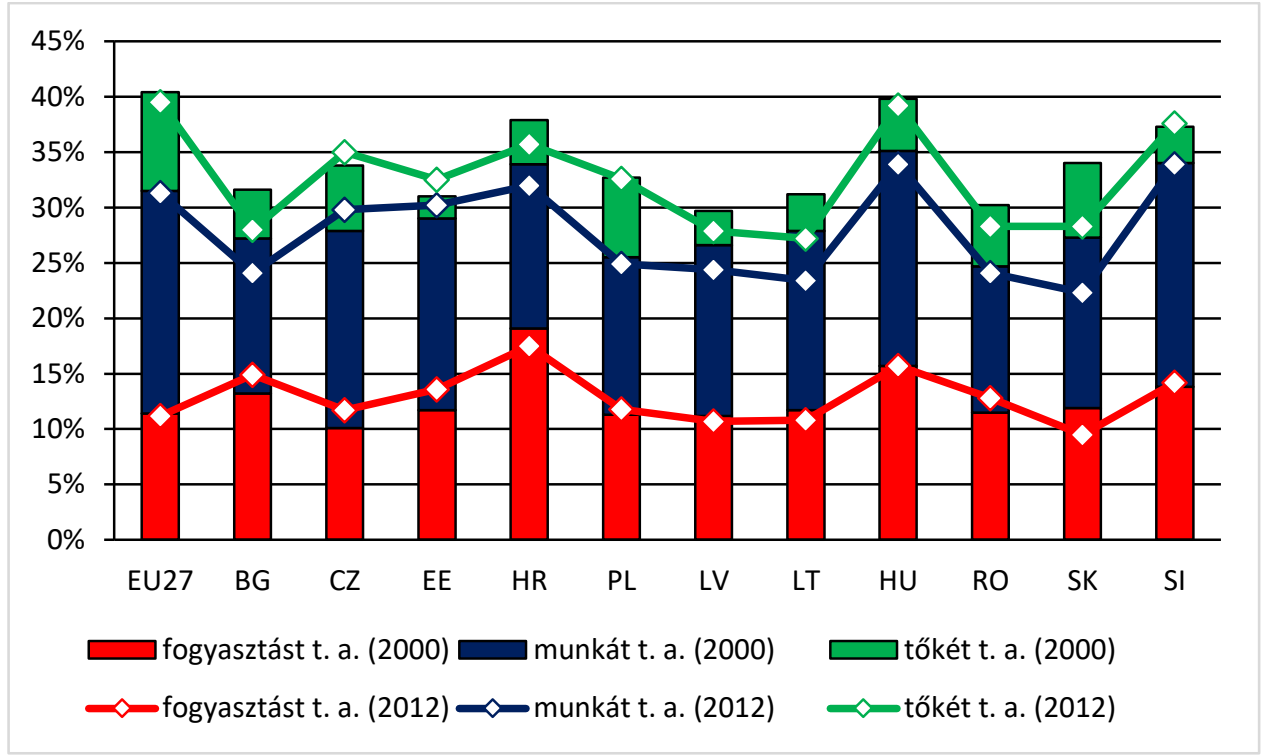

Saját szerkesztés az Eurostat (2014) adatai alapján

Megjegyzés: Horvátország esetében 2000 helyett 2002-es adat szerepel. Jelmagyarázat:

BG: Bulgária, CZ: Csehország, EE: Észtország, HR: Horvátország, PL: Lengyelország,

LV: Lettország, LT: Litvánia, HU: Magyarország, RO: Románia, SK: Szlovákia, SI: Szlovénia

Egy másik gyakran használt felosztás az adóterhek közgazdasági funkciók szerinti csoportositása. Ebben a tekintetben megkülönböztetünk fogyasztást, munkát,

${ }^{94} \mathrm{Ez}$ a súlyozott átlagot jelenti, a súlyozatlan átlag 30,4 százalék, vagyis a kelet-közép-európai értékek ehhez viszonyítva is alacsonyabbak. 
illetve tőkét és tőkejövedelmeket terhelő adókat. A fogyasztást terhelő adók közé tartozik az általános forgalmi adó, a jövedéki adó, valamint egyéb, kisebb jelentőségü tételek (például Magyarországon a népegészségügyi termékadó, a telekommunikációs adó vagy a pénzügyi tranzakciós illeték). A munkát terhelő adók csoportja a személyi jövedelemadó ${ }^{95}$ mellett magába foglalja a társadalombiztosítási járulékokat is. A harmadik csoportba pedig egyrészt a vállalati nyereségadók, másrészt a tőkejövedelmek (osztalék, kamat, árfolyam-nyereség) adói, harmadrészt a vagyonadók tartoznak.

A 20. ábrán e három csoportnak a GDP-arányát láthatjuk, míg a 21. ábrán a teljes adóbevételen belüli százalékos megoszlásukat. Az Eurostat (2014) összeállítása 2000-től 2012-ig közli ezeket az adatokat ${ }^{96}$, azonban Horvátország esetében csak 2002-től indul az adatsor. Így értelemszerűen EU-28 átlag sincs 2000-re, ezért viszonyítási pontként az EU-27 Horvátország nélküli átlagát használjuk. Mivel ez súlyozott átlag, így a fejlettebb nyugat-európai országok dominálják, vagyis megközelítőleg a hozzájuk való relatív helyzet bemutatására is alkalmas.

Az adócentralizáció tekintetében minden volt szocialista ország az európai átlag alatt helyezkedik el 2000-ben és 2012-ben is. Magyarország kiemelkedik az adócentralizációt illetően (ahogy az 5.4. alfejezetben láttuk, ez a teljes költségvetés méretében is megmutatkozik), majd Szlovénia, Horvátország és Csehország következik. Több országban is jelentékeny csökkenés figyelhető meg 2000-2012 között. A szlovák államháztartási reformról már többször ejtettem szót, ennek hatása értelemszerüen itt is megnyilvánul (az adóbevételek GDP-aránya 5,8 százalékponttal csökkent). Emellett Litvániában (-3,7 százalékpont), Bulgáriában (-3,6 százalékpont), Horvátországban (-2,2 százalékpont), Romániában (-1,9 százalékpont) és Lettországban ( $-1,8$ százalékpont) is érzékelhetően mérséklődött az adócentralizáció, elsősorban a válság során visszaeső adóbevételek hatására.

Valamelyest már a 20. ábrán is látszik, de a 21. ábrán még tisztábban kirajzolódik a nyugat-európai és volt szocialista országok adószerkezete közötti különbség. A kelet-közép-európai térség minden országában nagyobb (2000-ben és 2012ben is) a fogyasztási adók súlya, mint az EU-átlag. A munkát, illetve tőkét terhelő

${ }^{95}$ Ez teljes egészében akkor igaz, ha a személyi jövedelemadó csak a munkajövedelmekre vonatkozik, míg az egyéb (kamat, osztalék stb.) jövedelmek elkülönülten adóznak. Ha azonban az ezeket is magába foglaló teljes összevont jövedelemre van kivetve, akkor a személyi jövedelemadó megoszlik a munkát és tőkét terhelő adók csoportja között.

${ }^{96} \mathrm{Az}$ újabb kiadásban (Eurostat, 2015) egyáltalán nem szerepel az adóbevételeknek ez a csoportositása. 
adók esetében már csak valamivel enyhébb állítást lehet tenni: a fogyasztási adók nagyobb aránya 2012-ben kilenc országban járt együtt a tőkét terhelő adók, nyolc országban pedig a munkát terhelő adók kisebb költségvetési szerepével. Az az ábrából is egyértelmü, hogy a volt szocialista országok sem tekinthetők homogénnek az adószerkezetet illetően (egyfelől érdemes kiemelni a balti államok vagy Szlovénia esetében a tőkét terhelő adók alacsony mértékét, másfelől a fogyasztási adók még régiós összevetésben is nagy dominanciáját Bulgáriában), azonban összevetve az EU nyugati részével látható a hangsúlykülönbség: míg az EU-átlag szerinti megoszlás megközelítőleg 30-50-20 százalék, addig a volt szocialista országokban ez inkább 40-45-15 százalékot jelent.

21. ábra: Az adóbevételek közgazdasági funkciók szerinti bontása az adóbevételek százalékában

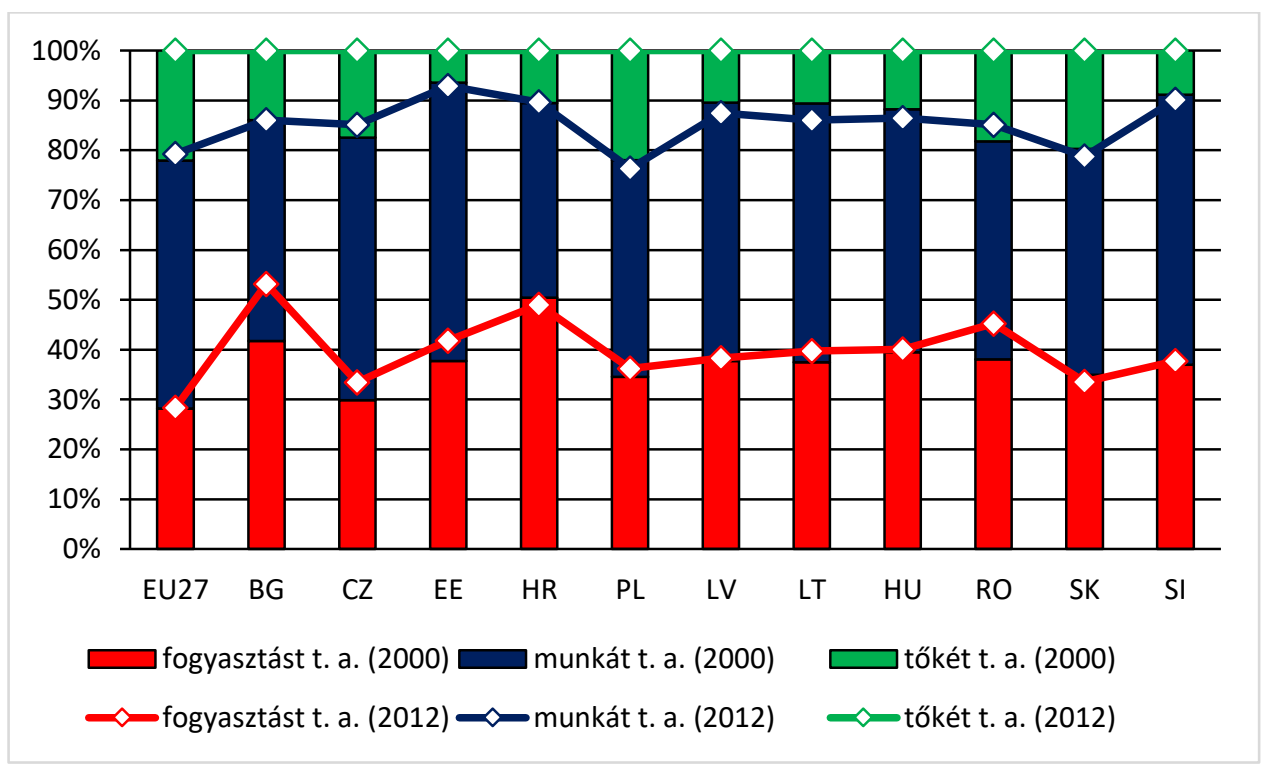

Saját szerkesztés az Eurostat (2014) adatai alapján

Megjegyzés: Horvátország esetében 2000 helyett 2002-es adat szerepel. Jelmagyarázat: BG: Bulgária, CZ: Csehország, EE: Észtország, HR: Horvátország, PL: Lengyelország, LV: Lettország, LT: Litvánia, HU: Magyarország, RO: Románia, SK: Szlovákia, SI: Szlovénia

Ennek több oka is van. A tőkét terhelö adók kapcsán elsősorban a nemzetközi adóverseny jelenségét kell kiemelni. A kelet-közép-európai országok hagyományosan tőkeszegények a fejlettebb gazdaságokhoz képest, ezért nagyon lényeges a külföldi tőke bevonása számukra. Ez - mint ahogy azt a 4.5. alfejezetben is láttuk - az itt alkalmazott növekedési modell egyik kulcseleme, amely egyfelöl az országok többségében lehetővé tett egy relatíve gyors közeledést Nyugat-Európa fejlettségi 
szintjéhez, másfelől viszont a nagymértékű pénzügyi nyitottság komoly sebezhetőséget is okozott több országban, így súlyosbítva a világgazdaság lassulásának helyi hatásait. A tőkevonzó képességnek sok tényezője van, hiszen amikor a tőketulajdonos arról dönt, hol fektessen be, számos szempontot mérlegel: az elérhető piac méretét, a munkaerő képzettségét és árát, a fizikai infrastruktúra minőségét, a gazdaságpolitika és jogi környezet kiszámíthatóságát stb. Emellett természetesen az adók szintje is fontos szempont - és ráadásul szinte az egyetlen, amely révén a volt szocialista országok versenyelőnyre tehettek, tehetnek szert a fejlettebb gazdaságokhoz képest, legalábbis rövid távon.

A másik ilyen potenciális versenyelönyt a munkaerő alacsonyabb költsége jelentheti. Ennek szintén van adópolitikai vonatkozása, hiszen a kisebb jövedelemadóteher csökkenti az adott minőségü (és adott nettóbér-igényü) munkaerő alkalmazásának költségét. Ezt általánosabban is meg lehet fogalmazni, hiszen nem csak a tőkevonzó képességhez kapcsolódik. A kelet-közép-európai országok többsége a rendszerváltozás óta tartósan rosszabb foglalkoztatási mutatókkal rendelkezik, mint Nyugat-Európa $^{97}$, és az alacsonyabb adóék egyszerre bővítheti a munkaerő-keresletet (olcsóbbá válik az adott nettó bérű munkavállaló foglalkoztatása) és a munkaerőkínálatot (ugyanakkora bruttó bér nagyobb nettó jövedelmet eredményez). Ráadásul az alacsonyabb jövedelemadó-kulcsok az adófizetési hajlandóságot is javíthatják.

A tőkét és munkát terhelő adókból így kieső összeget viszont a fogyasztási adókból lehet pótolni. Ahogy a 20. ábrán láthattuk, a régiós országok többségében nem csak az adóbevételeken belüli súlyát, hanem GDP-arányát tekintve is nagyobb ennek az adókörnek a szerepe. Ehhez az is hozzájárul, hogy a fogyasztási adók beszedése kevésbé költséges, illetve kisebb az adóelkerülés súlya. ${ }^{98}$

Az adószerkezetről elmondottak az adókulcsok tekintetében is megfigyelhetők. A 22. ábra a legmagasabb személyi jövedelemadó-kulcsokat mutatja az Európai Unió országaiban. A volt szocialista országok pirossal vannak jelölve - többségük az ábra jobbszélén látható. Hét esetben ez egykulcsos jövedelemadó-rendszert jelent, vagyis a legmagasabb adókulcs egyben az egyetlen is. De érdemes kiemelni, hogy

\footnotetext{
${ }^{97}$ Itt alapvetően a válság előtti „,békeévekre” gondolok, hiszen az utóbbi években több nyugat-európai ország (legfőképpen Görögország, Spanyolország, Portugália) is komoly foglalkoztatottsági problémákkal küzd, a kelet-közép-európai régió lemaradása viszont nem a válság eredménye, hanem hoszszabb távü örökség.

${ }^{98}$ Természetesen az áfa-csalás is súlyos probléma (akár az ezzel kapcsolatos nagy botrányokra gondolunk, akár a számla nélküli szolgáltatásnyújtás szinte mindennapos jelenségére), azonban ezekben az esetekben legális jövedelem sem keletkezik, vagyis az áfa elcsalása együtt jár a jövedelemadó elcsalásával is. Ezzel szemben nem minden jövedelemadó-csalásnak van fogyasztási adókat érintő vonzata.
} 
még a progresszív rendszert alkalmazó Lengyelországban és Szlovákiában is lényegesen alacsonyabbak a felső kulcsok, mint Nyugat-Európában. Ez alól csak Szlovénia és Horvátország a kivétel. Voltak adóváltoztatások az elmúlt két évtizedben mindkét országban, de a felső adókulcs végig 40-50 százalék között (sőt, Horvátország esetében 2003-2009 között afölött) volt, ami már a 2000-es évek eleje óta rendkívülinek számít a volt szocialista országok körében.

22. ábra: A legmagasabb személyi jövedelemadó-kulcsok az Európai Unió országaiban (2015)

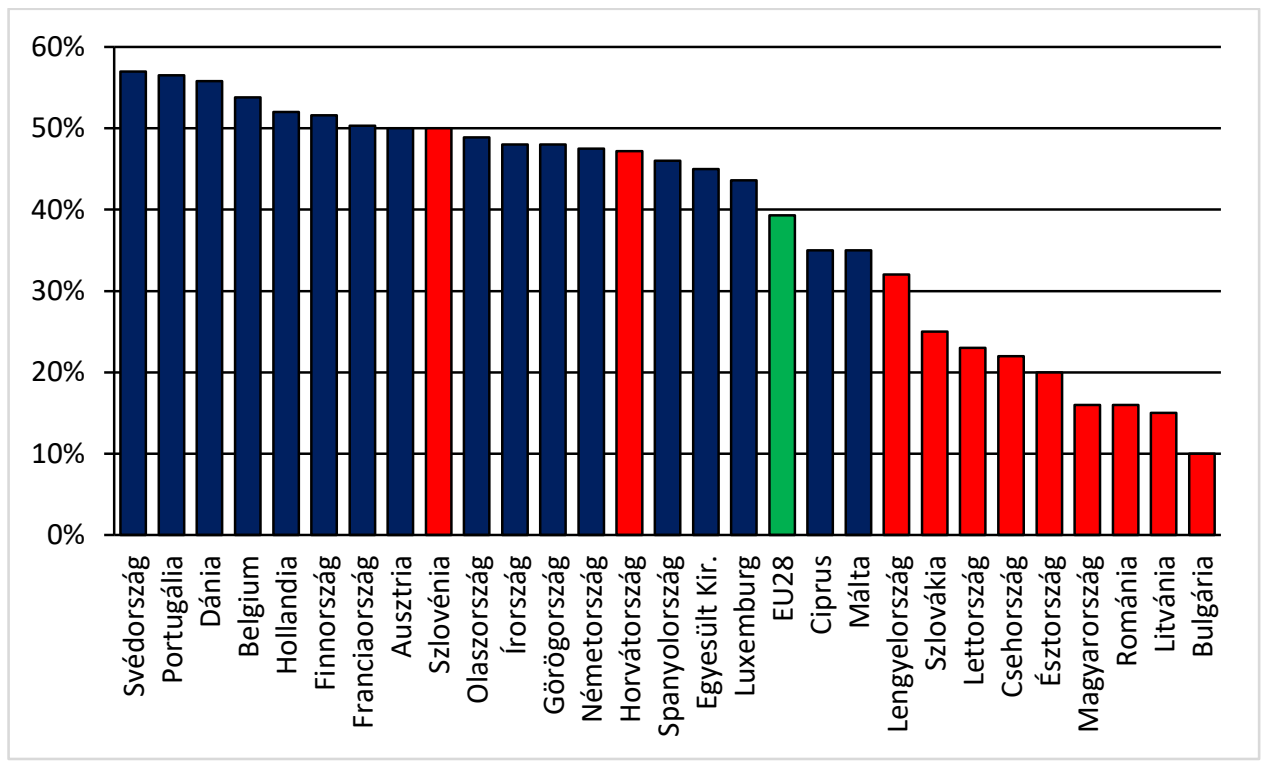

Saját szerkesztés az Eurostat (2015) adatai alapján

Jelenleg a vizsgált 11 országból 7 alkalmazza az egykulcsos személyi jövedelemadó valamilyen formáját. A három balti állam kezdte a sort 1994-1995-ben. Kezdetben az alkalmazott adókulcsok viszonylag magasak voltak: Észtországban 26, Lettországban 25, Litvániában 33 százalék. Ezeket a 2000-es évtized második felében Észtország és Litvánia több lépcsőben 21, illetve 15 százalékra mérsékelte. Az egykulcsos adót különféle kedvezmények egészítik ki mindhárom országban. Ez részben a megszerzett jövedelmek típusára vonatkozik, de Észtországban fix összegü, míg Litvániában a jövedelem emelkedésével csökkenő adómentes sáv (lecsengő adójóváírás) is van. Az adómentes sávok alkalmazása azt jelenti, hogy a jövedelem emelkedésével nő az átlagos adókulcs, vagyis annak ellenére is érvényesül egyfajta progresszivitás az adórendszerben, hogy a határadókulcsok a legmagasabb jövedelmek esetén is alacsonynak mondhatók. 
Románia 2005-ben, Bulgária 2008-ban vezetett be kifejezetten alacsony mértékü egykulcsos jövedelemadó-rendszert: 16, illetve 10 százalékos mértékkel. Ezekben az országokban nincsenek általános érvényü kedvezmények, vagyis nem érvényesül progresszivitás az adóztatásban. Ezzel szemben Csehországban van fix összegü adómentes sáv a szintén 2008-ban bevezetett egykulcsos szja-rendszerben (15 százalékos kulccsal vezették be, a költségvetési egyensúly helyreállítása érdekében 2013-ban emelték 22 százalékra).

Magyarország 2011-ben csatlakozott a lineáris adóztatást alkalmazó országok csoportjához. 2011-ben a lecsengő adójóváírás részleges meghagyásával, teljes eltörlésük után 2012-ben pedig a szuperbruttósítás részleges kivezetésével még enyhe progresszivitás érvényesült az adórendszerben, azonban ez 2013-tól eltűnt, és a jövedelemadó tökéletesen lineárissá vált. Legalábbis a gyermeket nem nevelő családok esetében ez a helyzet, a gyermekek után járó nagymértékü adóalap-kedvezmények a gyermekes háztartások esetén progresszivitáshoz vezetnek.

Az egykulcsos adó kapcsán meg kell említeni Szlovákiát is, ahol 2004-ben vezettek be egykulcsos adórendszert: 19 százalékos rátát alkalmaztak a személyi jövedelmek és a társasági jövedelmek adóztatásában, illetve az általános forgalmi adóban is. Az egykulcsos szja-rendszert itt is fix összegű adómentes sáv egészítette ki, vagyis szerepet kapott a progresszivitás. Az elmúlt években - részben a válság hatására megváltozott költségvetési körülmények eredményeként, részben a 2012ben másodszor is hatalomra kerülő Fico-kormányzat gazdaságpolitikai ideológiájából következően - számos változtatáson ment keresztül a rendszer. Az adómentes sávot már 2011-ben lecsengő jóváírás-jellegűvé változtatták, illetve az áfa általános kulcsát is emelték 1 százalékponttal. A nagyobb változtatások azonban 2013-ban következtek be. A személyi jövedelemadóban bevezettek egy 25 százalékos felső sávot, míg a társasági adó kulcsát 23 százalékra emelték, amit aztán egy évvel később 22 százalékra mérsékeltek. ${ }^{99}$

Ahogy fentebb már esett erről szó, a kelet-közép-európai országok nagyon jelentős adóversenyt folytattak a tőkevonzó képességük javítása érdekében. Noha a fogyasztási és munkát terhelő adók is relevánsak a beruházók telephely-választási

\footnotetext{
${ }^{99}$ A Függelék F6. ábráján kirajzolódik az alapvetően a felső adókulcsok csökkenését jelentő trend, de az is látható, hogy az Horvátországban és Lettországban közvetlenül a válság nyomán, másik három országban 2013-ban emelkedtek a kulcsok. Ami az egykulcsos adó jövőjét illeti, több országban is napirendre került a progresszív rendszerhez való visszatérés (ami Szlovákiában meg is történt), de egyelőre nem egyértelmü, hogy ez a trend megfordulásának tekinthetö-e, vagy csak a költségvetési problémák kapcsán megjelenő átmeneti változásnak.
} 
döntéseinek szempontjából (hiszen befolyásolják a fizetőképes keresletet, illetve a munkaerő költségét), ez elsődlegesen a társasági adókban jelenik meg. Ahogy a 23. ábrán látjuk, az összes kelet-közép-európai országban az EU-átlagnál kisebb a vállalkozási jövedelmekre rakódó adóteher.

\section{3. ábra: A vállalati jövedelmeket terhelő legmagasabb adókulcsok az Európai Unió országaiban (2015)}

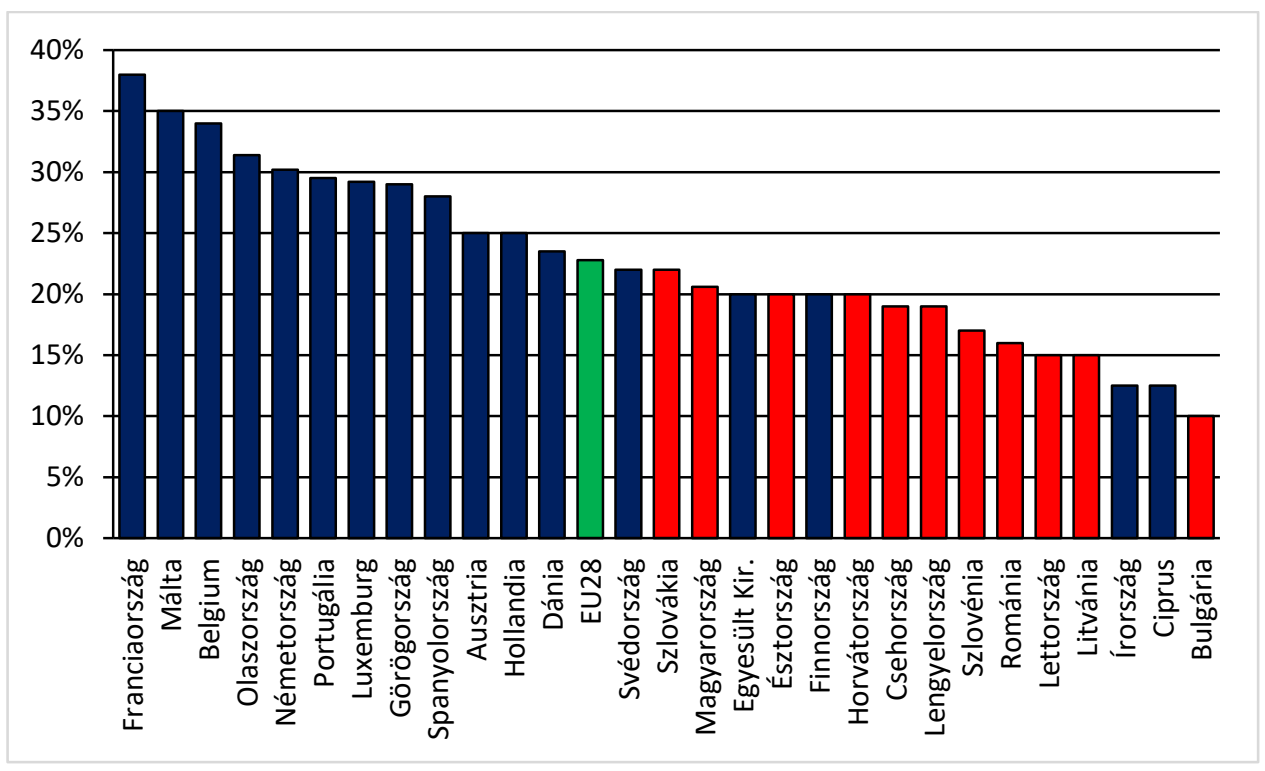

Saját szerkesztés az Eurostat (2015) adatai alapján

Az országok többségében ez a jelenlegi adóterhelés egy egyértelmüen és jelentősen csökkenő trend eredménye. (Függelék F7. ábra) Magyarországon és Szlovéniában változott legkisebb mértékben a társasági jövedelmek adóterhelése, ami annak is köszönhető, hogy ezekben az országokban már a vizsgált időszak elején jóval az uniós átlag alatti volt az adómérték. Hazánkban - ahol 1995-ben a régió legalacsonyabb szintjén állt a társasági adó kulcsa - valamelyest emelkedett is az adóteher (az ábra nem csak a társasági adót, hanem az egyéb, a társasági jövedelmekre vonatkozó adókat - például iparüzési adó - is tartalmazza). Hozzá kell tenni, hogy ez a (multinacionális vállalatok számára legfontosabb) felső adókulcsra vonatkozik, hiszen 2010 közepén progresszívvá vált a társasági adó Magyarországon: évi 500 millió forint nyereség alatt 10 százalékkal adóznak a vállalatok.

A társasági adók csökkentése azonban nem csak kelet-közép-európai jelenség, hanem az egész fejlett világra jellemző, a tőkemobilitás erősödésének köszönhető trend. Az Európai Unió átlagában 1995 és 2015 között a felső adókulcsok mértéke 
mintegy 12 százalékponttal csökkent. Ez csak részben köszönhető az új tagországokban megfigyelhető adómérséklésnek, hiszen több nyugat-európai tagországban is jelentősen csökkentették a társasági adót (Írországban, Németországban és Olaszországban a felső kulcsot több mint 20 százalékponttal).

Érdekes - bár az adószerkezet kapcsán a fogyasztási adókkal kapcsolatban elmondottakból következő - kontrasztban áll az eddigiekkel az általános forgalmi adó kulcsainak európai rangsora. (24. ábra) A személyes és vállalati jövedelmekre rakódó adóterhek esetén a volt szocialista országok az ábrák jobboldalán csoportosultak, ezzel szemben az áfa esetében sokkal egyenletesebben oszlanak el: öten az EU-átlag felett, hatan valamivel alatta. Az Unió legmagasabb általános áfa-kulcsa pedig Magyarországon van érvényben. Ez a különböző relatív pozíció egyértelműen következik az eltérő adószerkezetből, abból, hogy az alacsonyabb adócentralizáció mellett nagyobb a fogyasztást terhelö adók súlya a kelet-közép-európai országokban, mint Nyugat-Európában.

24. ábra: Általános áfa-kulcsok az Európai Unió országaiban (2015)

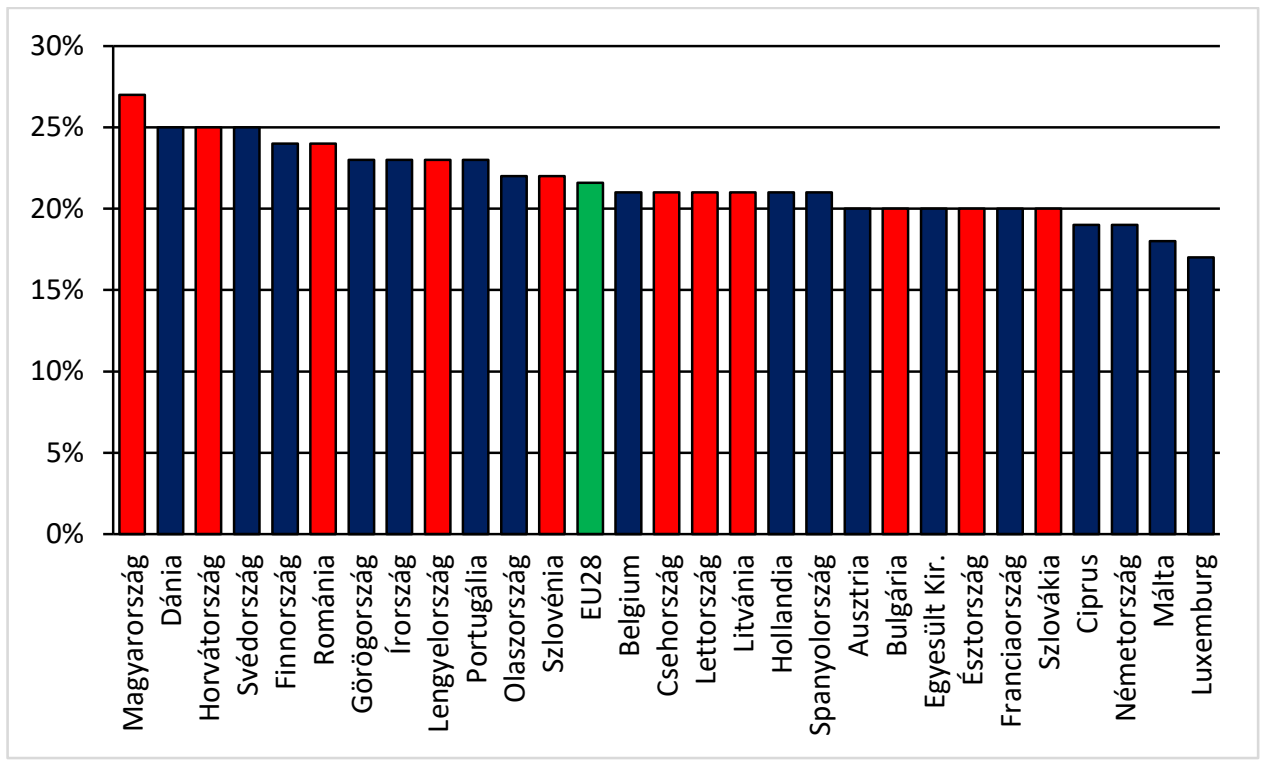

Saját szerkesztés az Eurostat (2015) adatai alapján

Az általános forgalmi adó kulcsai esetében kisebb az időbeli változások mértéke, de azt ki kell emelni, hogy az elmúlt években a válság nyomán romló költségvetési helyzet orvoslásának céljából Bulgária kivételével a régió összes országában emelték az általános áfa-kulcsot (ez a jelenség Nyugat-Európában is megfigyelhető), 
a legnagyobb mértékben éppen Magyarországon, ahol 2008-ban még 20 százalék volt. ${ }^{100}$ (Függelék F8. ábra)

Összességében kirajzolódik a kelet-közép-európai országok adóztatási gyakorlatának néhány közös vonása. Általánosan elmondható, hogy a térségünkben az adóbevételek GDP-aránya alatta marad a nyugat-európai átlagnak, a kisebb adóterhelés a gazdasági növekedést hivatott serkenteni. Az adók szerkezetében is megfigyelhetök eltérések a két országcsoport között: az új tagállamokban nagyobb a fogyasztási adók súlya, míg kevésbé támaszkodnak a munka- és tőkejövedelmek (illetve a vagyon) adóztatására, mint a fejlettebb országok. A társasági és személyi jövedelemadók kulcsait jelentősen csökkentették az elmúlt másfél-két évtizedben. Az adóztatás egyszerüsítése nyolc vizsgált országban is egy szja-kulcshoz vezetett, noha közülük azóta Szlovákia visszatért a progresszív jövedelemadóztatáshoz.

\subsection{Politikai költségvetési ciklusok Kelet-Közép-Európában ${ }^{101}$}

A hosszú távú gazdasági növekedés egyik fontos meghatározója az intézmények minősége. Ennek egy fontos vonatkozása a gazdaságpolitika stabilitása vagy instabilitása. Oblath (2014a) Magyarország esetében mutatja be, hogy a gazdasági növekedés 2000-es években megfigyelhető megtorpanása jelentős részben a gazdaságpolitika instabilitására vezethető vissza. A makrogazdasági instabilitás egyik megjelenési formáját jelentik a gazdaságpolitika által generált, választásokra időzített ingadozások.

Tág értelemben véve a politikai üzleti ciklusok fogalma azt jelenti, hogy a politikai ciklusok valamilyen módon megjelennek a gazdasági folyamatokban. Az e jelenséget vizsgáló kutatási iránynak két fő ága van: az opportunista politikai üzleti ciklusok elmélete, illetve a (gazdaság)politikai ideológiákon alapuló ingadozások elmélete $^{102}$. Az előbbi modellcsalád szerint a politikusok fő célja a hatalom megszerzése, illetve megtartása, és ennek érdekében manipulálják a gazdasági folyamatokat.

\footnotetext{
${ }^{100}$ Mindhárom esetben (a személyi jövedelemadó, a társasági adó és az általános forgalmi adó esetében is) el kell mondani, hogy az adókulcsok (ráadásul a legfelső adókulcsok) alakulása csak egyik vonatkozása az adóterhelésnek. Fontos az esetlegesen meglévő több adókulcs egymáshoz való viszonya, illetve az adóalappal kapcsolatos szabályozás. Mindezzel együtt maguk az adókulcsok is fontos jellegzetességekre hívják fel a figyelmet.

${ }^{101} \mathrm{Ez}$ az alfejezet egy korábban megjelent cikk (Németh, 2015b) rövidített, részben átdolgozott változata.

${ }^{102}$ A magyar szakirodalomban lehet találkozni a „politikai elkötelezettség modelljei”, a „pártos modellek”, illetve a „partizán politikai üzleti ciklusok” elnevezéssel is az angol „partisan political business cycles" nyomán.
} 
Ha sikerül a választások közeledtével kedvező gazdasági eredményeket felmutatni, akkor ez növelheti a kormányzat számára az újraválasztás esélyét, akkor is, ha hoszszabb távon nem optimális (sőt, kifejezetten káros) a jelenleg sikeresnek tünő gazdaságpolitika. A fenntarthatóság érdekében természetesen idővel korrekcióra van szükség, így a választások előtt expanzív, azt követően restriktív gazdaságpolitikát figyelhetünk meg. E modellekben nincsenek ideológiai eltérések a politikusok között, ezzel szemben a politikai elkötelezettségen alapuló második modellcsalád pontosan ezeket a különbségeket helyezi a vizsgálat középpontjába. Eszerint a politikai pártok szavazóbázisának eltérő gazdasági érdekeik és elvárásaik vannak, és a politikusok nem engedhetik meg maguknak, hogy ne igyekezzenek megfelelni ezeknek az elvárásoknak. Ebből következően a különböző ideológiát magukénak valló kormányzatok váltakozása okoz érzékelhető ingadozást a gazdasági folyamatokban. Ebben az esetben tehát nem a választási és nem választási évek között figyelhető meg eltérés, hanem a bal- és jobboldali kormányok időszakai között. ${ }^{103}$

Az opportunista politikai üzleti ciklusok modellirányzata Nordhaus (1975) híres cikkétől eredeztethető. A megközelítés kiindulópontjaként ez a modell mindmáig fontos, noha a későbbiekben sok kritika érte. A modell középpontjában tisztán opportunista, csak a hatalom megszerzésével/megtartásával törődő politikusok állnak, akik úgy alakítják az infláció és munkanélküliség kombinációját, hogy az a választások közeledtével lehetőleg minél több (szintén politikailag nem elkötelezett) szavazó elvárásainak megfeleljen. Erre a várakozásokkal kibővített Phillips-görbe ad lehetőséget: a vártnál nagyobb inflációt eredményező monetáris politikával rövidtávon csökkenthető a munkanélküliség. A munkanélküliség visszafogását célzó monetáris expanzió inflációs költségei azonban hosszabb távon nagyobbak, mint rövid távon. Így a választások előtti élénkítést később megszorításnak kell követnie a megugró infláció leszorítása érdekében.

A modell választói rövidlátók (nem látják előre, hogy mi történik a választások után, döntésüket a jelenre és a közelmúltra alapozzák), illetve feledékenyek (a korábbi évek tapasztalatai kisebb súllyal esnek latba a szavazás során). Ez kulcsfontosságú, hiszen így a szavazók viselkedése manipulálható: a választások előtti expanzív gazdaságpolitikával anélkül lehet rövid távon javítani a gazdasági helyzeten, hogy a szavazók előre látnák, hogy a választások után megszorításoknak kell követ-

${ }^{103}$ Az elméleteknek, illetve az irányzat fejlődésének részletesebb kifejtése megtalálható Drazen (2000), Benczes és Ürögdi (2008), valamint Németh (2014) tanulmányaiban. 
kezniük. Másrészt a feledékenység azt is jelenti, hogy ezt újra és újra eljátszhatják a politikusok, hiszen a következő választásokig már a feledés homályába merül, hogy az előző alkalommal hogyan vezették félre a választópolgárokat.

Ahogy fentebb jeleztem, több lényegi kritika is megfogalmazható a Nordhaus-modellel kapcsolatban. Elöször is, a modellben a ciklikus manipulációt a választók irracionalitása (rövidlátás és feledékenység) teszi lehetővé. Noha természetesen a szavazók racionalitása korlátozott, de ez a fajta irracionalitás túlzó feltevésnek tünik, a valóságban az emberek idővel képesek kiismerni ezeket a politikai folyamatokat, és nem lehet őket újra és újra ugyanúgy becsapni. Éppen ezért az opportunista politikai ciklus modellek későbbi generációi már racionális választókat feltételeznek, és emellett a feltevés mellett keresnek magyarázatot a ciklikusságra. Ezt a politikusok és választók között fennálló aszimmetrikus információs helyzetben (második generáció), illetve a rövid távú elönyök és hosszabb távú hátrányok közötti átváltással kapcsolatos általános bizonytalanságban (harmadik generáció) találják meg.

Másodszor, noha az 1970-es években még helytálló lehetett, azóta már lényegesen kevésbé az az a feltevés, hogy a kormányzat a monetáris politikán keresztül képes hatni a gazdasági folyamatokra. A kormánytól független jegybankok korában a monetáris politika alakítóit nem a választásokhoz kötődő politikai szempontok vezérlik. Másfelől a Nordhaus-modellből viszont teljes mértékben hiányoznak a fiskális politikai eszközök, noha a költségvetés bevételeinek és kiadásainak alakítása mind a mai napig a politikai döntéshozók kezében van. Így az utóbbi évtizedekben a témakör kutatóinak figyelme átterelödött a költségvetési ciklusok vizsgálatára. Ez a váltás elsősorban Rogoff és Sibert (1988), illetve Rogoff (1990) tanulmányaihoz kötődik, a politikai költségvetési ciklus kifejezés is utóbbiban jelenik meg először. Ebben a megközelítésben a ciklikusság már nem a monetáris változókban (pénzmennyiség, infláció), illetve ennek következtében a munkanélküliségben figyelhető meg, hanem az adóbevételek és a kormányzati kiadások, valamint természetesen a költségvetési egyenleg alakulásában. Az alfejezet későbbi részében szereplő empirikus eredmények is erre fókuszálnak.

A harmadik fő kritika a Nordhaus-modellel szemben az, hogy az ideológiai szempontok teljes egészében hiányoznak. Ez persze úgy is megfogalmazható, hogy a modell valójában csak az ingadozó szavazókkal foglalkozik, azokkal, akik nincsenek erősen elkötelezve egyik oldal iránt sem. Az elkötelezettek viselkedése úgyis egyér- 
telmü, a választások kimenetele a bizonytalanokon múlik, akiknek a döntését erősen befolyásolhatja a gazdasági helyzet. Ez igaz, de a valóságban nem ennyire egyértelmü a probléma, hiszen a politikai pártoknak nem csak a bizonytalanok minél nagyobb arányát kell maguk mellé állítaniuk a választási győzelem érdekében, hanem az is fontos, hogy fenntartsák a törzsszavazóik aktivitását. Ha egy konzervatív szavazó nem is szavaz esetleg egy baloldali pártra, az elképzelhető, hogy egyáltalán el sem megy szavazni, ha elégedetlen a konzervatív kormányzat teljesítményével. És ez megakadályozhatja a kormánypárt újabb győzelmét. Vagyis nem elég csak az ideológiailag nem elkötelezett szavazók meggyőzésére törekedni, a pártok nem engedhetik meg maguknak, hogy ne képviseljék törzs-szavazóbázisuk érdekeit. Pontosan ez áll a gazdaságpolitikai ideológiákon alapuló ingadozások modelljeinek fókuszában.

Ennek az elméletnek a kiinduló, meghatározó tanulmánya Hibbs (1977) nevéhez füződik. Alapja az a felismerés, hogy a hagyományos politikai pártok, politikai oldalak törzs-szavazóbázisai között szignifikáns gazdasági-társadalmi eltérések vannak. A baloldali, szociáldemokrata pártok tradicionálisan az alacsonyabb jövedelmüek, többségében bérből és fizetésből élők csoportjában erősek. Számukra a gazdaságpolitika sikerességének elsődleges fokmérője a foglalkoztatottság és a gazdasági növekedés. A költségvetés tekintetében pedig a nagyobb újraelosztás, nagyobb kiterjedésü közkiadási programok müködtetése (legyen szó oktatásról, egészségügyről, vagy akár foglalkoztatás-politikai programokról) áll érdekükben. Ezzel szemben a felsőbb jövedelmi rétegek, a tőkejövedelmekkel is rendelkezők általában nagyobb arányban szavaznak a jobboldali, konzervatív pártokra. Öket kevésbé fenyegeti a munkanélküliség veszélye, illetve a közkiadási programoknak is általában nettó teherviselői, így ők inkább a makropénzügyi stabilitásban (alacsony infláció, stabil költségvetési helyzet, kisebb újraelosztás) érdekeltek.

Ennek megfelelően a szociáldemokrata pártok által vezetett kormányzatok hajlamosabbak az expanzív gazdaságpolitikára, a nagyobb költségvetési kiadási szint fenntartására a (legalábbis rövid távon) gyorsabb reáljövedelem-növekedés vagy az alacsonyabb munkanélküliség érdekében. A konzervatív kormányzatok pedig inkább a költségvetési fegyelem fenntartására, kisebb újraelosztásra törekednek, akár a jóléti kiadások visszavágásán keresztül. Az empirikus eredmények szerint a kétpólusú politikai rendszerü országokban általában valóban megfigyelhetők eltérések a jobb- és baloldali kormányzatok időszakai között az infláció, a munkanélküliség és a költségvetési politika tekintetében is. 
Az opportunista politikai üzleti ciklusokhoz kapcsolódó empirikus eredmények meglehetősen vegyesek. A hagyományos, monetáris politikára épülő modellekhez kapcsolódó, fejlett országokra fókuszáló vizsgálatok (lásd például Golden és Poterba, 1980, Alesina és Roubini, 1992) nem találtak egyértelmü bizonyítékot a politika által motivált ciklusok létére. A fejlődő országok esetében viszont már megfigyelhető ez a fajta ciklikusság. Block (2002) például jelentős mértékű, választásokhoz igazodó ingadozást mutatott ki a monetáris politikában 44 afrikai ország mintáját elemezve. Az országcsoportok közötti különbség annak is köszönhető, hogy az afrikai (és általában a fejlődő) országokban általában lényegesen kevésbé függetlenek a jegybankok a kormányzattól.

Schuknecht (2000) 24 fejlődő ország mintáján kimutatta a fiskális ciklusok létét is. Eredményei szerint a kormányzatok elsősorban a költségvetés kiadási oldalát használták a választásokra időzített gazdaságpolitikai élénkítésre. A fejlett országokkal kapcsolatban a fiskális ciklusokra vonatkozó eredmények is vegyesek. Andrikopoulos, Loizides és Prodromidis (2004) 14 EU-tagállam 1970-1998 közötti adatait vizsgálva nem talált szignifikáns különbséget a választási és nem választási évek költségvetési helyzete között. Másrészt viszont Mink és de Haan (2006) bemutatták, hogy újabb adatokon már az európai országok körében is megfigyelhetőek az elméletből következő eltérések. Az eredmények közötti különbség valószínüleg abból fakad, hogy az 1990-es években a vizsgált országok szigorú költségvetési politikát voltak kénytelenek követni az euró bevezetése érdekében, míg ezt követően az erre vonatkozó ösztönzésük gyengébbé vált.

A 7. táblázat az eurózóna 12 alapító tagállamának ciklikusan kiigazított elsődleges egyenleg ${ }^{104}$ adatait tartalmazza az 1995-2008 közötti időszakra. Az időhorizont szándékosan nem fedi le az utóbbi éveket, hiszen azok a hatalmas költségvetési hiányok, amelyek a gazdasági válság hatására megjelentek több országban is (például Írországban, Portugáliában vagy Spanyolországban), erősen torzítanák az eredményeket, mivel ezek a megugró deficitek alapvetően függetlenek a választásoktól. ${ }^{105}$ A rendkívüli választások, amikor a kormányzat lemondása vagy a parlament (ön)feloszlatása miatt van szükség elörehozott szavazásra, nem választási évként szerepelnek a táblázatban. Az opportunista politikai üzleti ciklusok elmélete szerint

\footnotetext{
${ }^{104}$ A ciklikus kiigazítás a GDP-trenden alapul.

105 A strukturális egyenleg használata részben kezelné ezt a problémát, azonban ezek az adatok az AMECO (2016) adatbázisban nem állnak rendelkezésre a vizsgált időszakra.
} 
ugyanis a kormányzatok a választásokra tudatosan készülve igyekeznek befolyásolni a gazdaság állapotát győzelmi esélyeik növelése érdekében. A kormánykoalíció hirtelen összeomlásakor, illetve hasonló esetekben egyszerüen nincs mód erre. ${ }^{106}$

7. táblázat: Politikai költségvetési ciklusok az eurózóna 12 alapító tagállamában, 1995-2008

\begin{tabular}{|c|c|c|c|}
\hline Ország & A választások száma* & $\begin{array}{l}\text { Átlagos ciklikusan } \\
\text { kiigazított elsődle- } \\
\text { ges egyenleg vá- } \\
\text { lasztási években }\end{array}$ & $\begin{array}{l}\text { Átlagos ciklikusan } \\
\text { kiigazított elsődle- } \\
\text { ges egyenleg nem } \\
\text { választási években }\end{array}$ \\
\hline Ausztria & $2(' 99$, ,06) & $0,6 \%$ & $0,9 \%$ \\
\hline Belgium & $4(' 95$, '99, '03, '07) & $4,7 \%$ & $5,0 \%$ \\
\hline Finnország & $4(' 95$, '99, '03, '07) & $3,1 \%$ & $4,7 \%$ \\
\hline Franciaország** & $4(' 95$, '97, ’02, ’07) & $-0,6 \%$ & $-0,1 \%$ \\
\hline Görögország & $4(' 96$, '00, ’04, ’07) & $-0,4 \%$ & $0,4 \%$ \\
\hline Hollandia & $3(' 98$, ,02, ’06) & $2,2 \%$ & $2,3 \%$ \\
\hline Írország & $3\left(' 97,{ }^{\prime} 02,{ }^{\prime} 07\right)$ & $0,5 \%$ & $2,1 \%$ \\
\hline Luxemburg & $2\left(' 99,{ }^{\prime} 04\right)$ & $1,5 \%$ & $2,8 \%$ \\
\hline Németország & $2\left(’ 98,,^{\prime} 02\right)$ & $0,1 \%$ & $0,3 \%$ \\
\hline Olaszország & $2(' 01, ’ 06)$ & $1,1 \%$ & $3,2 \%$ \\
\hline Portugália & $2(' 95, ' 99)$ & $0,3 \%$ & $-1,3 \%$ \\
\hline Spanyolország & $3\left({ }^{\prime} 00,,^{\prime} 04,{ }^{\prime} 08\right)$ & $-0,6 \%$ & $1,6 \%$ \\
\hline
\end{tabular}

Saját számítások az AMECO (2016) adatai alapján

Megjegyzés: *A rendkívüli választások (1995 Ausztriában, 1996 Olaszországban és Spanyolországban, 2002 Ausztriában és Portugáliában, 2003 Hollandiában, 2005 Németországban és Portugáliában, 2006 Hollandiában, 2008 Ausztriában és Olaszországban) nem választási évként szerepelnek. ** Parlamenti és elnökválasztások is

Látható, hogy egy ország (Portugália) kivételével mindenhol kirajzolódik a különbség a választási és nem választási évek között: a költségvetési helyzet roszszabb az előbbiekben. A legtöbb országban mérsékelt ez az eltérés, de a minta majdnem felében eléri az 1 százalékpontot. Portugália kivételes helyzete nagyrészt annak köszönhető, hogy az átlagos elsődleges egyenleg lényegesen jobb volt 1995-1999 között, mint 2000-2008 között (0,2 százalék, illetve -1,9 százalék). Mindkét rendes választásra az előbbi időszakban került sor, míg a másodikban mindössze két rendkívüli választás volt az országban.

Összességében azt mondhatjuk, hogy az empirikus megfigyelések erős, politika által motivált ciklikusságot mutatnak a fejlődő országokban, míg a fejlett világra vonatkozó eredmények vegyesek. Bizonyos időszakokban egyáltalán nem mutatható

106 Azok az elörehozott választások, amelyekre csak néhány hónappal a tervezettnél korábban kerül sor (például 2006 Hollandiában vagy 2007 Görögországban), rendes választásként kerülnek figyelembe vételre, hiszen ezekben az esetekben a kormányzat tudja, hogy a közeljövőben választások lesznek. 
ki a ciklikusság ezekben az országokban, más időszakokban igen. De még ezekben a periódusokban is általában lényegesen enyhébb a ciklikusság, mint a fejlődő régiók államaiban.

Azonban Brender és Drazen (2003, 2005) vizsgálatai kimutatták, hogy valójában nem is a gazdasági fejlettség számít, hanem az, hogy mekkora demokratikus rutinnal rendelkeznek az állampolgárok. Az újabb demokráciákban a választóknak egyszerủen nincs elég ismeretük arról, hogyan is müködik a képviseleti rendszer, milyen ösztönzői vannak a racionális politikusoknak, illetve hogyan tudják manipulálni a gazdasági folyamatokat, és ezen keresztül az állampolgárok benyomásait. Vagyis a politikai költségvetési ciklikusság leküzdése egy tanulási folyamat: ahogy a választók egyre több és több rutinra tesznek szert, egyre ellenállóbbá válnak a politikusok szavazatszerző kísérleteire. Sőt, kellő tapasztalat és ismeret esetén kifejezetten „büntethetik” azokat. Természetesen, önmagában az idő nem elegendő. Sok intézmény (legyen szó akár költségvetési szabályokról vagy például egy független és erős sajtóról) müködése és minősége befolyásolja, hogy kialakul-e és ha igen, mennyi idő alatt alakul ki ez a választói rutin.

A kelet-közép-európai országok ideális vizsgálati terepnek tekinthetők a politikai költségvetési ciklusok szempontjából, hiszen mindegyikük új demokrácia, és a rendszerváltozás ráadásul megközelítőleg ugyanakkor zajlott le mindannyiuk esetében. Mégis, mint az alábbiakban látható lesz, megfigyelhetők közöttük különbségek a ciklusok tekintetében.

Az alábbiakban a költségvetési folyamatokra koncentrálok, és ezek vizsgálatára a továbbiakban is az AMECO (2016) adatbázis ciklikusan kiigazított elsődleges egyenleg adatait használom. Az államadósság utáni kamatterhek ugyanis minden időpontban adottak, tehát a rövid távú költségvetési élénkítéseknek és megszorításoknak meg kell jelenniük az elsődleges egyenlegben. A ciklikus kiigazítás is fontos, hiszen így a diszkrecionális döntések hatása elkülöníthető a gazdasági ingadozások automatikus költségvetési következményeitől.

A vizsgálati idöhorizont továbbra is az 1995-2008 közötti éveket öleli fel. Mivel relatíve rövid időszakról van szó, így a válság kitörését követő évek megugró deficitjei erősen elmozdítanák az átlagokat, és ezzel elfednék a válság előtt megfigyelhető különbségeket a választási és nem választási évek, illetve a baloldali és 
jobboldali kormányzatok periódusai között. ${ }^{107}$ Ugyanebből az okból kifolyólag az 1995-ben induló idősorok ideálisak, hiszen a rendszerváltozást követő első években szintén kiugró mértékü egyensúlytalanságokat lehetett megfigyelni egyes országokban. Csehország és Szlovénia esetében az 1996-os évet is kihagytam, hiszen ez év hatalmas hiányai egyértelműen outliernek bizonyulnak e két ország esetében ${ }^{108}$, így jelentősen torzítanák az eredményeket.

8. táblázat: Politikai költségvetési ciklusok a kelet-közép-európai országokban, 1995-2008

\begin{tabular}{|c|c|c|c|}
\hline Ország & Választások száma* & $\begin{array}{l}\text { Átlagos ciklikusan } \\
\text { kiigazított elsődle- } \\
\text { ges egyenleg vá- } \\
\text { lasztási években }\end{array}$ & $\begin{array}{l}\text { Átlagos ciklikusan } \\
\text { kiigazított elsődle- } \\
\text { ges egyenleg nem } \\
\text { választási években }\end{array}$ \\
\hline Bulgária & $2(' 01, ' 05)$ & $4,2 \%$ & $4,0 \%$ \\
\hline Csehország $^{* *}$ & $3(' 96$, '02, ’06) & $-3,4 \%$ & $-2,8 \%$ \\
\hline Észtország & $3(' 99$, '03, '07) & $-0,6 \%$ & $0,3 \%$ \\
\hline Lengyelország & $3(' 97$, '01, ’05) & $-1,0 \%$ & $-0,7 \%$ \\
\hline Lettország & $2\left(' 02,{ }^{\prime} 06\right)$ & $-2,2 \%$ & $-1,3 \%$ \\
\hline Litvánia & $4(' 96$, '00, '04, '08) & $-2,4 \%$ & $-2,3 \%$ \\
\hline Magyarország & $3(' 98$, ,02, ’06) & $-4,4 \%$ & $-0,3 \%$ \\
\hline Románia & $4(' 96$, '00, '04, '08) & $-2,9 \%$ & $-0,2 \%$ \\
\hline Szlovákia & $3(' 98$, '02, '06) & $-3,2 \%$ & $-2,9 \%$ \\
\hline Szlovénia $^{* *}$ & $4(' 96$, '00, '04, '08) & $-1,3 \%$ & $-0,4 \%$ \\
\hline
\end{tabular}

Saját számítások az AMECO (2016) adatai alapján

Megjegyzés: *A rendkívüli választások (1995 Észtországban és Lettországban, 1997 Bulgáriában, 1998 Csehországban és Lettországban, 2007 Lengyelországban) nem választási évként szerepelnek. ** $1996-2008$

A 8. táblázat mutatja 10 kelet-közép-európai EU-tagállam ciklikusan kiigazított elsődleges egyenleg adatait. ${ }^{109}$ Mivel szinte mindegyik ország parlamentáris demokrácia, ezért csak a törvényhozási választásokat vizsgáltam. Az egyetlen kivétel a fél-elnöki berendezkedésű Románia, ahol a végrehajtó hatalom megoszlik a kormányzat és az elnök között. Azonban 2008-at megelőzően az elnökválasztásokra a törvényhozási választásokkal együtt került sor, vagyis ez nem befolyásolja az adat-

\footnotetext{
107 Az opportunista politikai költségvetési ciklusok tekintetében Németh (2014) tanulmánya tartalmazza az 1995-2012 közötti időszakra számított átlagokat is. A következtetések meglehetősen hasonlóak az itt közölt, rövidebb időszakra vonatkozó eredményekhez. Ami a pártos megközelítést illeti: világszerte megfigyelhető volt, hogy a kormányzatok élénkítő programokat indítottak a gazdasági válság leküzdése érdekében - függetlenül attól, hogy konzervatív vagy szociáldemokrata kormányokról beszélünk. Ezért indokolt a 2008 utáni évek kihagyása, hiszen ez a jelenség elmosná az esetleges különbségeket a bal- és jobboldali kormányok között.

${ }^{108}$ Mindkét esetben a későbbi évek átlagánál legalább négyszer nagyobb hiányról van szó.

${ }^{109}$ Horvátország adathiány miatt nem szerepel a vizsgálatban.
} 
bázist. Újfent megjegyzem, hogy a fiskális politikát nem lehet rendkívüli választásokhoz igazítani, így ezeket az eseteket nem választási évként vettem számításba.

Ahogy látható a táblázatból, a 10-böl 9 ország esetében az elsődleges egyenleg átlagosan rosszabb a választási években, mint egyébként. Az egyetlen kivétel Bulgária, ahol két rendes választást tartottak a vizsgált időszakban (2001 és 2005). A választások alacsony száma hozzájárul ehhez a mintától elütő eredményhez, azonban az is igaz, hogy az egyik választási évben (2001) Bulgária az egész megfigyelési időszak harmadik legnagyobb elsődleges többletét produkálta (a GDP 6,4 százaléka), ami lényegesen jobb a megelőző és a rákövetkező év adatánál is. Természetesen az, hogy ezen kívül csak egy másik választás volt, felerősíti ennek a rendkívüli évnek a hatását az egész átlagra.

Az országok többségében mérsékelt a különbség a választási és nem választási évek költségvetési helyzete között. Mindössze két országban nagyobb a ciklikusan kiigazított elsődleges egyenlegben mutatkozó eltérés a GDP 1 százalékánál: Romániában 2,7 százalékpont, míg Magyarországon ennél is nagyobb, 4,1 százalékpont. ${ }^{110}$ Három másik országban (Észtország, Lettország és Szlovénia) 0,9 százalékponttal rosszabb elsődleges pozíciót jelentenek a választások.

A választási évek elsődleges egyenlegét lehet hasonlítani a megelőző és a rákövetkező évhez annak érdekében, hogy kirajzolódjanak az esetleges fiskális sokkok. A 31 normál választás közül 24 esetben (77,4 százalék) romlott az elsődleges egyenleg a választási években az előző évhez viszonyítva. Úgy látszik, a kormányzatok hajlamosabbak voltak a választások közeledtével kiadásokat emelni, mint visszafogni azokat a választások után a költségvetés stabilizálása érdekében. A 31-ből csak 17 esetben (54,8 százalék) csökkent a deficit, vagy nőtt az elsődleges többlet a választásokat követő évre.

Összevetve a 7. és 8. táblázatok eredményeit azt láthatjuk, hogy mind az eurózóna alapító tagállamaiban, mind a kelet-közép-európai országokban megfigyelhető a választásokra időzített költségvetési lazítás (12-ből 11, illetve 10-ből 9 ország esetében). Ennek átlagos mértékében sincs érdemi különbség a két országcsoport között, mindkét minta fele esetében közelíti vagy haladja meg a ciklikusan kiigazított

\footnotetext{
${ }^{110}$ A magyar eset leírását lásd Halász (2014) tanulmányában. Elemzése szerint a költségvetési ciklusok elsősorban a háztartásoknak nyújtott transzferekben és a közszféra béreiben mutatkoztak meg Magyarországon, vagyis domináns módon a kiadási oldalon jelentek meg. Hozzá kell tenni, hogy noha egy általánosan kirajzolódó mintából lehet következtetéseket levonni a politikailag motivált ciklikusságra vonatkozóan, ezt mindig nagyon nehéz konkrét döntésekre, intézkedésekre lefordítani, hiszen azok számos különböző motiváció eredőjeként alakulnak ki.
} 
elsődleges egyenlegben mutatkozó ingadozás a GDP 1 százalékát. Amiben viszont lényeges eltérés látható, az az átlagos egyenlegpozíció. A fejlettebb nyugat-európai országban egy (akár jelentős) átlagos elsődleges többlethez képest figyelhető meg valamekkora lazítás a választások évében, míg a volt szocialista EU-tagállamok döntő többségében egy amúgy is meglévő elsődleges hiányt súlyosbít tovább a politikai célzatú expanzió. E két eset között nagy különbség van a makrogazdaság-politika kiszámíthatóságába vetett bizalom, és azon keresztül a növekedési kilátásokra vonatkozó hatás tekintetében.

Annak a jelenségnek, hogy a választási ciklusok megjelennek a költségvetési adatokban - konkrétabban: hogy a választási években általában romlik az egyenleg az opportunista politikai ciklusok elméletén kívül más magyarázata is lehet. Az alternatív magyarázatot az adósság stratégiai alkalmazásának modelljei adják. ${ }^{111}$ Ezek lényege, hogy a kormányzat azért halmoz fel hiányt és adósságot a választások előtt, mert attól tart, hogy veszíteni fog a voksoláson, és így legalább részben meg tudja kötni a következő kormány kezét. Az eladósodás ugyanis tulajdonképpen azt jelenti, hogy a bejövő, más ideológiájú kormányzat költségvetési forrásainak egy részét már a mostani kormány elkölti. Ráadásul így az új kormánynak a költségvetési egyensúly helyreállítására kell koncentrálnia ahelyett, hogy saját gazdaságpolitikai elképzeléseit követhetné. Ha például a konzervatív kormányzat szeretné megakadályozni, hogy a hatalomra kerülő szociáldemokrata párt megnövelje a költségvetési újraelosztás mértékét, akkor érdemes adót csökkentenie a választások előtt, így megnehezítve az általuk károsnak tartott cél elérését.

Erre az elméletre felfüzve Takács és Benczes (2014) más narratíváját adja az elmúlt húsz év kelet-közép-európai költségvetési folyamatainak. Noha természetesen lehetetlen tökéletesen elkülöníteni az opportunista politikai költségvetési ciklus, a stratégiai adósság-felhalmozás, illetve a más (akár ideológiai, akár szakpolitikai) okokkal indokolható költségvetési intézkedések hatásait, azonban azt gondolom, hogy térségünkben erösebb a politikai költségvetési ciklus magyarázó ereje, mint az adósság stratégiai alkalmazásáé.

Egyrészt a választások többségének eredménye relatíve szoros volt, elöre egyáltalán nem lehetett elkönyvelni egyik vagy másik oldal győzelmét (természetesen vannak kivételek, mint a 2005-ös lengyel vagy a 2010-es magyar választás). Egy

\footnotetext{
${ }^{111}$ Az irányzat összefoglalását lásd Takács és Benczes (2014) tanulmányában.
} 
ilyen helyzetben a kormányzat inkább van arra ösztönözve, hogy megpróbálja saját hatalmon maradását elősegíteni, mint hogy megnehezítse a választások után felálló kormányzat (könnyen lehet, hogy saját maga) dolgát. Vagyis a választások előtt megnövekvő hiányt inkább magyarázhatja a szavazatszerzési cél, mint a stratégiai adósság-felhalmozás. Magyarországon is rendkívül szoros volt az 1998-as, 2002-es és 2006-os választás is, a közvélemény-kutatások vegyes elörejelzéseket adtak, az ezekben az években elért kiugró költségvetési hiányok így jobban illeszkednek a politikai üzleti ciklusok elméletkörébe.

Másrészt az adósság stratégiai alkalmazásának modelljeiben a költségvetési kiadások mellett a bevételek alakításának is kulcsszerep jut. Ahogy fentebb utaltam rá, az elmélet értelmében a konzervatív kormányzatok például kifejezetten adócsökkentéssel nehezíthetik meg a választások megnyerésére esélyes ellenzékük helyzetét. Ezzel szemben a gyakorlati tapasztalatok azt mutatják, hogy a térségbeli kormányzatok szívesebben nyúlnak a kiadási oldalhoz. Takács és Benczes (2014) is számos ilyen epizódot említ meg, illetve ez látszik a magyar adatokon is. A bevételek GDParánya 1998-ban és 2002-ben 1 százalékponttal csökkent a megelőző évhez képest, 2006-ban pedig növekedett is. A kiadások változása ennél érdemben hangsúlyosabb volt: 1998-ban ugyan csak 1 százalékponttal emelkedett a GDP-arányuk, 2002-ben azonban 4 százalékponttal, 2006-ban 2 százalékponttal. ${ }^{112}$

Harmadrészt azt is érdemes megemlíteni, hogy a stratégiai adósságfelhalmozás modelljeit alapvetően kétpólusú politikai rendszerekre dolgozták ki, ahol többé-kevésbé lehet tudni, hogy milyen gazdaságpolitika várható a pártoktól. Ahhoz, hogy a leköszönő kormányzat meg tudja kötni a hatalomra kerülők kezét, szükséges, hogy tudja, mire kell számítania tőlük. Kelet-Közép-Európa arányos, illetve részben arányos választási rendszerei azonban többpárti parlamentekhez vezetnek, és a változó összetételü koalíciók esetében ez az előrejelzés lényegesen kevésbé müködik. Ráadásul a térség új demokráciáiban még a fejlettebb országokhoz képest kiforratlanabbak a politikai ideológiák, illetve a hagyományos konzervatív-szociáldemokrata gazdaságpolitikai törésvonal nem feltétlenül elsődleges fontosságú. Ugyanez jelenik meg abban is, hogy - mint az alábbiakban látni fogjuk - a politikai ideológiákon alapuló különbségek kevéssé figyelhetők meg a térségbeli országok költségvetési adatain.

112 Ahogy fentebb már hivatkoztam rá, Halász (2014) is a kiadási oldalon mutatta ki a magyar politikai költségvetési ciklusokat. 
A politikai ideológiákon alapuló eltérések vizsgálata némileg kevésbé egyértelmü ebben a régióban. Az elméletet alapvetően kétpólusú politikai rendszerekre dolgozták ki, míg az európai országokban általában lényegesen magasabb a pártok száma - alapvetően a kontinens sok országában alkalmazott arányos (vagy részben arányos) választási rendszereknek köszönhetően. Ráadásul - mint fentebb is említettem - az új demokráciák pártjainak ideológiái általában kevésbé stabilak és letisztázottak, illetve sok esetben a pártok közötti törésvonalak más mintát is követnek, mint Nyugat-Európában.

Először a különböző kormányzó politikai pártok ideológiáit határoztam meg a klasszikus hármas bontás (konzervatív, liberális, szociáldemokrata) szerint. Ehhez a pártok öndefinícióit és az európai vagy nemzetközi pártcsaládokhoz való kötődéseit használtam. Így például az Európai Néppárt (European People’s Party), illetve az Európai Konzervatívok és Reformisták (European Conservatives and Reformists) tagjait konzervatívként, a Szocialisták és Demokraták Progresszív Szövetségének (Progressive Alliance of Socialists and Democrats) tagjait szociáldemokrataként, a Liberálisok és Demokraták Szövetsége Európáért (Alliance of Liberals and Democrats for Europe) tagjait liberálisként könyveltem el. Az olyan koalíciós kormányokat, ahol a résztvevő pártok különböző pártcsoportok tagjai, a legnagyobb kormánypárt ideológiája, illetve a miniszterelnök párthovatartozása alapján soroltam be.

Ezt követően ezt a háromosztatú csoportosítást kellett az elméletnek megfelelő kétpólusú bontássá alakítani. Az egyértelmü, hogy a konzervatív kormányzatokat jobboldaliként, a szociáldemokratákat baloldaliként kezelhetjük. A liberális kormányzatokat a koalícióban részt vevő többi párt ideológiája, valamint a legnagyobb liberális párt jobb-, illetve baloldali pártokkal való együttmüködési hajlandósága alapján csoportosítottam.

Mivel az adott év költségvetését az előző évben kell elfogadni, és ennek megfelelően az újonnan megválasztott kormányzat legkorábban csak a következő év költségvetése felett rendelkezik teljes szabadsággal ${ }^{113}$, ezért ebben a vizsgálatban minden kormány ciklusát a választást követő évvel kezdtem.

${ }^{113}$ Bár például a 2002-es vagy akár a 2010-es év magyarországi választásai után évközben is jelentős változások következtek be a költségvetési politikában. 


\begin{tabular}{|c|c|c|}
\hline Ország & $\begin{array}{c}\text { Átlagos ciklikusan kiiga- } \\
\text { zított elsődleges egyenleg } \\
\text { baloldali kormányok alatt }\end{array}$ & $\begin{array}{c}\text { Átlagos ciklikusan kiiga- } \\
\text { zított elsődleges egyenleg } \\
\text { jobboldali kormányok } \\
\text { alatt }\end{array}$ \\
\hline Bulgária & $3,4 \%$ & $5,6 \%$ \\
\hline Csehország & $-2,8 \%$ & $-3,1 \%$ \\
\hline Észtország & --- & $0,1 \%$ \\
\hline Lengyelország & $-0,5 \%$ & $-1,1 \%$ \\
\hline Lettország & --- & $-1,4 \%$ \\
\hline Litvánia & $-1,8 \%$ & $-3,6 \%$ \\
\hline Magyarország & $-1,7 \%$ & $0,3 \%$ \\
\hline Románia & $-0,2 \%$ & $-1,5 \%$ \\
\hline Szlovákia & $-4,1 \%$ & $-2,1 \%$ \\
\hline Szlovénia & $-0,1 \%$ & $-0,9 \%$ \\
\hline
\end{tabular}

Saját számítások az AMECO (2016) adatai alapján

Megjegyzés: *1996-2008

Az eredmények a 9. táblázatban láthatók. Az alkalmazott csoportosítás szerint Észtországban és Lettországban nem volt baloldali kormány a vizsgált időszakban. A többi nyolc országból három (Bulgária, Magyarország, Szlovákia) esetében a baloldali kormányzatok alatt szignifikánsan rosszabb volt a költségvetési helyzet, mint a jobboldali kormányok idején. A különbség mindhárom esetben legalább 2 százalékpont. A másik öt országban viszont ennek az ellenkezője látható. A legmeglepőbb eredményt Litvánia produkálja, de ez lényegében egy évnek köszönhető: konzervatív kormányzat volt hatalmon 1997-ben, amikor a ciklikusan kiigazított elsődleges hiány elérte a GDP 11,5 százalékát. Ezt az egy évet kivéve a mintából, az ország jobboldali kormányzatai átlagosan 1 százalékos elsődleges hiányt produkáltak. Románia esete hasonló, a 2008-as 9 százalékos elsődleges hiány idején liberáliskonzervatív koalíció kormányzott. A maradék három országban a jobb- és baloldali kormányzatok ciklusainak átlagos költségvetési pozíciói között kevesebb mint 1 százalékpont a különbség. Ezzel együtt is az egyértelmü, hogy a kelet-közép-európai országok többségének adatain nem láthatóak azok a különbségek az eltérő ideológiájú kormányzatok költségvetési eredményei között, amit a modellek sugallnak. 


\section{KONKLÚZIÓ}

Az értekezés két elkülönülő, mégis összefüggő részből tevődött össze, melyek más megközelítésben foglalkoztak a gazdasági növekedés kérdéseivel. A 2-3. fejezet a növekedéselmélet és a hozzá kapcsolódó empirikus módszertanok bemutatására vállalkozott, míg a 4-5. fejezet a kelet-közép-európai országok elmúlt 25 éves teljesítményét vizsgálta és értékelte az elméleti összefüggések fényében.

A 2. fejezet célja az volt, hogy bemutassa a növekedéselmélet fejlödéstörténeti ivét Smith és Malthus 18. század végi gondolataitól napjainkig. Végigvettem e fejlödési folyamat legfőbb lépcsőfokait, beleértve a Harrod-Domar-modellt, a Solowmodellt, a technológiai fejlődést endogén módon magyarázó elméleteket, valamint a humán tőke, illetve az intézmények szerepét kiemelő irányzatokat. A formális modellek részletes elemzése helyett (egy-egy esetben mellett) arra törekedtem, hogy egymásra hatásukat, a közöttük fellelhető kapcsolódási pontokat domborítsam ki.

Az elmélettörténetet mintegy kiegészíti a 3. fejezet, amely a gazdasági növekedés empirikus vizsgálatának három módszertanát ismertette. A növekedési számvitel egy-egy ország növekedési teljesítményét, a fejlettségi számvitel pedig az egy referenciaországhoz viszonyított jövedelmi különbségeket dekomponálja a termelési tényezők szerint. A harmadikként leírt növekedési regresszió olyan ökonometriai modellt jelent, amelyben a függő változó egy időszak átlagos növekedési üteme, a magyarázó változók között pedig megjelennek a népesedés, tőkefelhalmozás, humántőke-állomány vagy intézményi minőség különböző mutatói. A módszertanok bemutatása mellett igyekeztem felhívni a figyelmet azok korlátaira is, valamint empirikus eredményeket is idéztem.

Bár a 2. és 3. fejezetet is a kelet-közép-európai régióra vonatkozó alfejezet zárta, a 4. fejezetben fordultam teljes mértékben e térség tapasztalatai felé. A tizenegy volt szocialista EU-tagállam elmúlt negyedszázados növekedési teljesítményét vizsgáltam, ahol lehetett, igyekeztem rámutatni a közös mintákra, máshol a különbségeket domborítottam ki. E fejezet legfontosabb állításai:

- A gazdasági növekedés szempontjából az elmúlt huszonöt év a térség minden országában három jól elkülönülő szakaszra osztható: transzformációs visszaesés, felzárkózási periódus, majd a pénzügyi válság nyomán visszaesés és ütemvesztés. 
- A transzformációs recesszió a rendszerváltozás természetes velejárója, Kornai (1993) nyomán kijelenthetjük, hogy olyan speciális jellemvonásokkal rendelkezik, amelyek megkülönböztetik más (ciklikus) visszaesésektöl: a koordinációs mechanizmusok közötti „vákuum”; a relatív árak jelentős megváltozása által kiváltott strukturális átrendeződés (a schumpeteri „teremtő rombolás" sajátos formája); a kereslet-vezérelt gazdaság kialakulása, ami felerösíti az aggregált kereslet visszaesésének hatását.

- A recessziót mindenhol egy gyors növekedési periódus követte, melynek eredményeként az összes térségbeli ország lényegesen közelebb került a nyugat-európai országok fejlettségi szintjéhez.

- E gyors növekedés elsődleges motorja a tőkefelhalmozás volt, amit jól mutatnak a nyugat-európai szintnél lényegesen magasabb nettó beruházási ráták.

- A belső megtakaritások elégtelensége miatt ez a gyors tőkefelhalmozás nem lett volna lehetséges külső források bevonása, vagyis nagymértékü FDIbeáramlás nélkül.

- A forrásbevonásnak a gyors tőkefelhalmozás mellett másik következménye a hatalmas folyófizetésimérleg-hiányokban megmutatkozó külső egyensúlytalanság. A mérleghiány mértéke öt országban is meghaladta a GDP 10 százalékát, ekkora (sőt, már a többi kelet-közép-európai országban megfigyelhető valamivel kisebb) mértékủ egyensúlytalanság hosszú távon nem fenntartható.

- A folyó fizetési mérleg hatalmas hiánya más tényezőkkel (mint például az exportpiacoktól való függés vagy a romló versenyképesség) együtt rendkívül sebezhetővé tette a régió országait. Ennek megfelelően Lengyelország kivételével mindenhol jelentősen visszaesett a gazdaság kibocsátása a pénzügyi válság nyomán.

- A GDP-csökkenés mellett a pénzügyi válság másik fontos következménye, hogy azt követően lényegesen (1,5-5 százalékponttal) lelassult a gazdasági növekedés üteme a válságot megelőző időszakhoz képest. Ennek oka a tőkebeáramlás visszaesése, valamint a felvevőpiacok lassulása, amelyek nélkül a térség kis, nyitott gazdaságai nem tudnak a korábbiakhoz hasonló ütemben növekedni.

- A növekedési ütem várható további mérséklődését vetítheti elöre az $E U$ transzferek jelentős szerepe, hiszen ezek csökkenése a jövőben érdemben visszavetheti a beruházási aktivitást és azon keresztül az aggregált keresletet. 
Az 5. fejezet a gazdasági növekedés átfogó témakörének egy szeletére összpontosít: a költségvetési politika és növekedés kapcsolatára. Az erre vonatkozó elméleti és korábbi empirikus eredmények összefoglalása után a fejezet több részkérdésre is kitér, melyeknek fö következtetései az alábbiak:

- Az Európai Unió országaiban egyértelműen kirajzolódik a költségvetési kiadások és növekedési ütem közötti negatív, valamint az átlagos egyenleg és növekedési ütem közötti pozitív összefüggés. Ezzel összhangban van a 2002es adósságráta és a 2002-2015 közötti átlagos növekedési ütem között megfigyelhetö negativ irányú kapcsolat is. Mindez nem tagadja azt, hogy a közkiadások pozitívan is hozzájárulhatnak a növekedéshez, inkább úgy interpretálható, hogy az EU országaiban többnyire nagyobb az állami aktivitás, mint ami a növekedés szempontjából optimális lenne.

- A kelet-közép-európai országokat átlagosan alacsonyabb újraelosztás és adósságráta jellemezte a vizsgált időszakban (ez alól Magyarország, valamint részben Horvátország és Szlovénia tekinthető kivételnek). Az egyenleg tekintetében teljesen heterogén a kép: Bulgáriában vagy Észtországban a költségvetési többlet a jellemző, míg 1998-2006 között mindegyik visegrádi országban mutatkoztak nagyon komoly deficitek.

- A gazdasági növekedés serkentése céljából a kelet-közép-európai országok adópolitikájában trendszerü eltérések figyelhetők meg a nyugat-európai gyakorlathoz képest. Ez megnyilvánul az alacsonyabb adócentralizációban, az eltérő adószerkezetben, és az alacsonyabb jövedelemadó-kulcsok alkalmazásában egyaránt.

- A makrogazdasági stabilitás szempontjából releváns politikai költségvetési ciklusok ugyanúgy megjelennek a volt szocialista országokban, mint az eurózóna tagállamaiban, a választásokhoz kötődő ingadozás mértékében sincs érdemi eltérés. Ami fontos különbség viszont, az az, hogy a fejlettebb nyugateurópai országban egy (akár jelentős) átlagos elsődleges többlethez képest figyelhető meg valamekkora lazítás a választások évében, míg a volt szocialista EU-tagállamok döntő többségében egy amúgy is meglévő elsődleges hiányt súlyosbít tovább a politikai célzatú expanzió.

- A kelet-közép-európai országok többségének adatain nem láthatóak különbségek az eltérő ideológiájú kormányzatok költségvetési eredményei között. Ennek oka, hogy az új demokráciák pártjainak gazdaságpolitikai ideológiái 
általában kevésbé stabilak és letisztázottak, illetve sok esetben a pártok közötti törésvonalak más mintát is követnek, mint Nyugat-Európában.

Bár az értekezés a kelet-közép-európai régió egészével foglalkozott, zárásként néhány gondolat erejéig külön kitérek Magyarország teljesitményére és növekedési kilátásaira.

A rendszerváltozás idején Magyarország az egyik legfejlettebb gazdaság volt a térségen belül - igaz, a magasabb jólétet jelentős részben eladósodás finanszírozta. A transzformáció menetére emellett az is hatással volt, hogy a gazdasági reformintézkedések egy részét már a rendszerváltozás előtt végrehajtották. Ez bizonyos tekintetben előny, hiszen az intézményrendszer a többi kelet-közép-európai országhoz képest már közelebb állt a piacgazdasági standardokhoz. Más tekintetben azonban hátrányt is jelent, hiszen az e reformok eredményeként létrejövő intézmények, bár jobban hasonlítottak a piacgazdasági megoldásokra, valójában nem voltak azok. A rendszerváltozást követően viszont nehezebben voltak megváltoztathatóak, mint ha újonnan kerültek volna kialakításra.

Maga a transzformációs recesszió - noha súlyos gazdasági és társadalmi következményekkel járt - a régió más országainak többségéhez képest viszonylag enyhének mondható (a kibocsátás teljes visszaesése csak Csehországban, Lengyelországban és Szlovéniában volt valamivel mérsékeltebb). Azonban - mint a 4.3. alfejezetben láthattuk - ezt követően Magyarország növekedése volt a leglassabb az öszszes kelet-közép-európai ország közül, az átlagos növekedési ütem alig haladta meg a 3 százalékot 1993-2008 között. Ha ebből az időszakból kivesszük a Bokroscsomag, majd a 2006-os stabilizációs intézkedések hatására bekövetkezett megtorpanások éveit, akkor is csak mintegy 4 százalékos átlagos növekedési ütemet kapunk az 1996-2006-os időszakra. Még ez is lassabb növekedést jelent, mint Horvátország kivételével bármelyik másik térségbeli országé a pénzügyi válságot megelőző felzárkózási periódusban - pedig más országokban is voltak olyan megtorpanások, amelyeket az utóbbi magyar adatnál már nem vettem számításba. Vagyis elmondható, hogy a magyar növekedés és reálkonvergencia haladt a leglassabban a volt szocialista országok közül. Ez látható a 4.3. alfejezetben már említett relatív pozícióvesztésen: az 1995-ben, de még 2000-ben is meglévő régiós harmadik helyröl 2008-ra a hatodik, 2015-re a hetedik helyre csúsztunk vissza.

Más (gazdaságszerkezeti és gazdaságpolitikai) okok mellett e gyengének nevezhető növekedési teljesítmény egyik lényeges tényezője, hogy a térség szinte egé- 
szében megfigyelhető külsö egyensúlytalanság mellett Magyarországot nagyon komoly fiskális politikai fegyelmezetlenség is jellemezte. A magyar költségvetési újraelosztás szinte folyamatosan a legmagasabb volt egész Kelet-Közép-Európában (ma is az), ez pedig a közkiadások alacsony hatékonyságán, illetve a finanszírozásukhoz szükséges adóterheken keresztül negatívan hatott a hosszú távú növekedési lehetőségekre, noha rövid távon az expanzív fiskális politikának volt élénkítő hatása. Ami ennél is fontosabb: semelyik másik térségbeli országban nem volt megfigyelhető olyan hosszú és nagymértékü költségvetési egyensúlytalanság, mint hazánkban. A költségvetési hiány 1995-2011 között minden évben meghaladta a GDP 3 százalékát, 2002-2006 között a 6 százalékát. Ennek köszönhetően a magyar eladósodottság a vizsgált időszak egészében lényegesen magasabb volt a térségbeli átlagnál. Hozzá kell tenni, hogy mindez természetesen nem független a társadalom szerkezetétől, elvárásaitól.

A költségvetési politika fentebb leírt problémái hozzájárultak ahhoz, hogy a 2006-ban szükségessé vált stabilizációs intézkedések hatására már a pénzügyi válságot megelözően, a többi térségbeli országnál hamarabb megakadt a gazdasági növekedés. Az is a fiskális politika fenntarthatatlanságának számlájára írható, hogy 20082009-ben a magyar kormányzat az általános nemzetközi gyakorlattal szemben nem tudott érdemi élénkitő lépéseket tenni, hanem a költségvetési hiány és az eladósodottság csökkentése érdekében restrikcióra kényszerült. Emiatt a 2009-es visszaesés sok térségbeli országnál súlyosabb volt hazánkban.

Ráadásul abban is jelentős a költségvetési politika szerepe, hogy a pénzügyi válságot Magyarországon nem a baltiakhoz hasonló „helyreállítási periódus” követte, hanem elhúzódó stagnálás gyakorlatilag 2014-ig. Ebben már nem csak a korábbi évekről örökölt adósságok játszottak fontos szerepet, hanem az egyensúly helyreállítása érdekében meghozott gazdaságpolitikai döntések is hozzájárultak, ugyanis ezek egy része (például a szektorális különadók, vagy a magánnyugdíj-megtakarítások átcsatornázása az államháztartásba) egyértelmüen rombolták a gazdaságpolitika kiszámíthatóságát. Ezen a kiszámíthatóságon feltétlenül javítani kell a jövőben ahhoz, hogy Magyarország növekedési lehetőségei javuljanak.

Sorra véve a különböző termelési tényezőket, amúgy is visszafogottnak tünnek ezek a növekedési kilátások:

- a rendelkezésre álló ásványkincsek, természeti erőforrások korlátozottak;

- a termőföld elaprózottsága a mezőgazdaság termelékenységére hat negatívan; 
- a töke tekintetében a vállalkozások (és ezen keresztül a termelöeszközök) szétaprózottsága jelent alacsonyabb termelékenységet a hazai tulajdonú kis és közepes vállalatok esetében;

- a külföldi müködő tőke beáramlása 2008 óta jelentősen lassult, a közeljövőben a befektetési és kockázatvállalási hajlandóság globális mérséklődése miatt nem várható ennek gyors újraindulása;

- az európai uniós támogatások jelentős növekedési tényezőt jelentettek az elmúlt időszakban, ezek jövőbeli csökkenése várhatóan szintén visszaveti a gazdasági növekedést;

- a többszázezer munkavállaló Nyugat-Európába áramlása komoly humántőke-veszteséget jelent a magyar gazdaságnak, figyelembe véve a képzettebbek és nagyobb kezdeményezőkészséggel, vállalkozókedvvel rendelkezők magasabb migrációs hajlandóságát;

- az elvándorlás hatására komoly feszültségek keletkeztek a munkaerőpiacon, a meglévő tartós munkanélküliség mellett egyre eröteljesebb munkaeröhiány is jelentkezik $^{114}$;

- nincs olyan migrációs utánpótlása a magyar gazdaságnak, amely orvosolni tudná a munkaeröpiac problémáit.

Mindebből következően ahhoz, hogy a következő években-évtizedekben érdemi gazdasági növekedést tudjunk elérni, illetve a folyamatosan megfogalmazott felzárkózási céloknak megfelelően mérséklődni tudjon a Nyugat-Európához viszonyított lemaradás, feltétlenül szükséges az intézményrendszer minőségének javítása. Ez jelenti a gazdaságpolitika stabilitását éppúgy, mint a korrupció csökkentését.

\footnotetext{
${ }^{114}$ A megjelenő munkaerőhiány azt jelenti, hogy Kornai (1980) szóhasználatával a gazdaságban újra
} egyre relevánsabbá válnak az erőforráskorlátok a keresleti korlátok mellett. 


\section{FÜGGELÉK}

F1. ábra: Az egyes korcsoportok aránya a kelet-közép-európai országokban

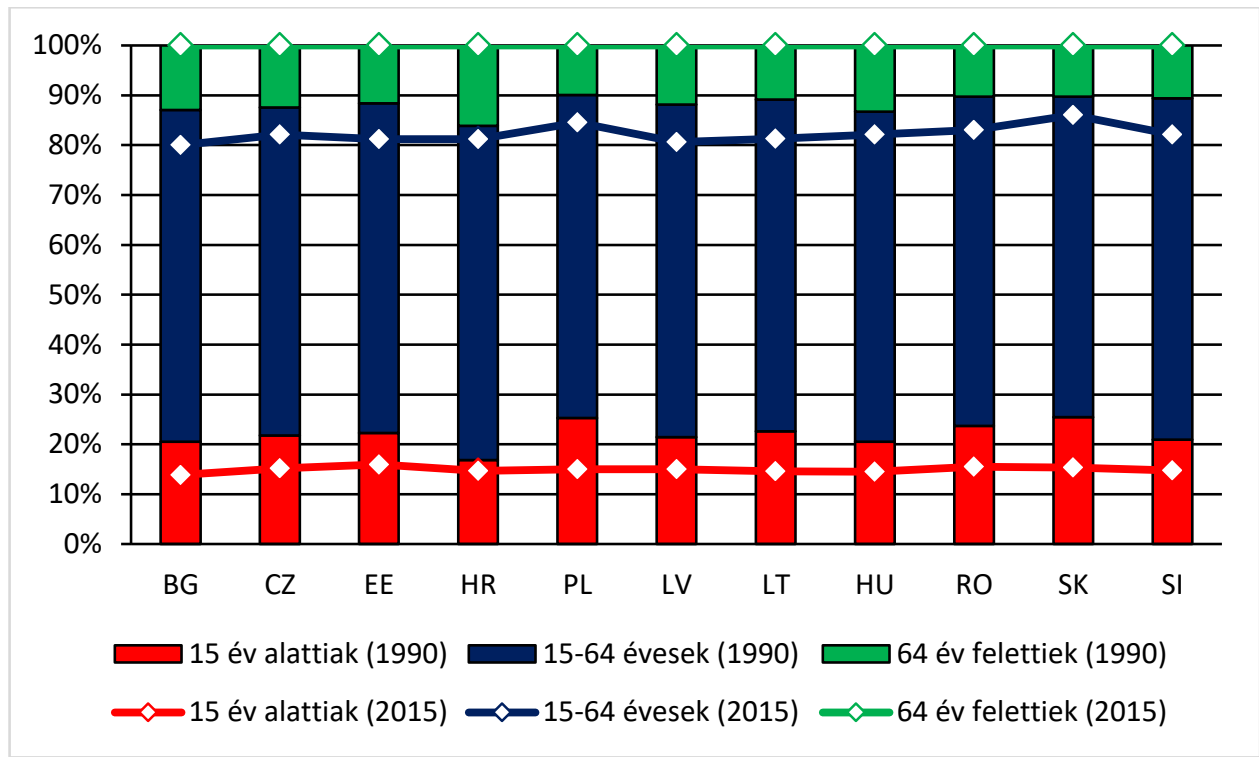

Saját szerkesztés az Eurostat (2016) adatai alapján

Megjegyzés: Horvátország esetében a korosztályok szerinti bontás csak 2001-től áll rendelkezésre, így esetükben az 1990-es adat helyett a 2001-es szerepel. Jelmagyarázat: BG: Bulgária, CZ: Csehország, EE: Észtország, HR: Horvátország, PL: Lengyelország, LV: Lettország, LT: Litvánia, HU: Magyarország, RO: Románia, SK: Szlovákia, SI: Szlovénia 
F2. ábra: A foglalkoztatotti létszám alakulása (1997 = 100\%)
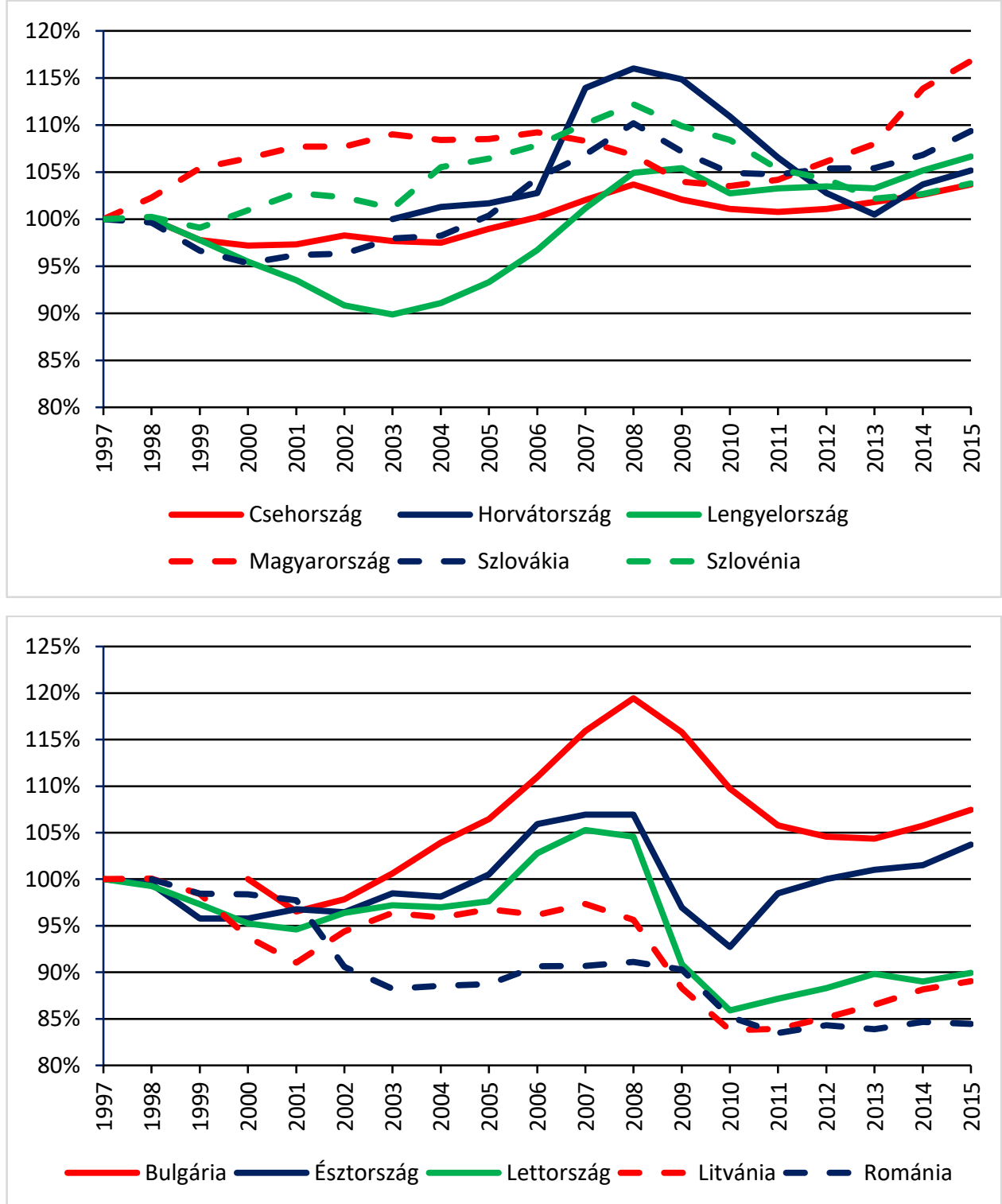

Saját szerkesztés az Eurostat (2016) adatai alapján 
F3. ábra: A foglalkoztatottsági ráta alakulása a kelet-közép-európai országokban
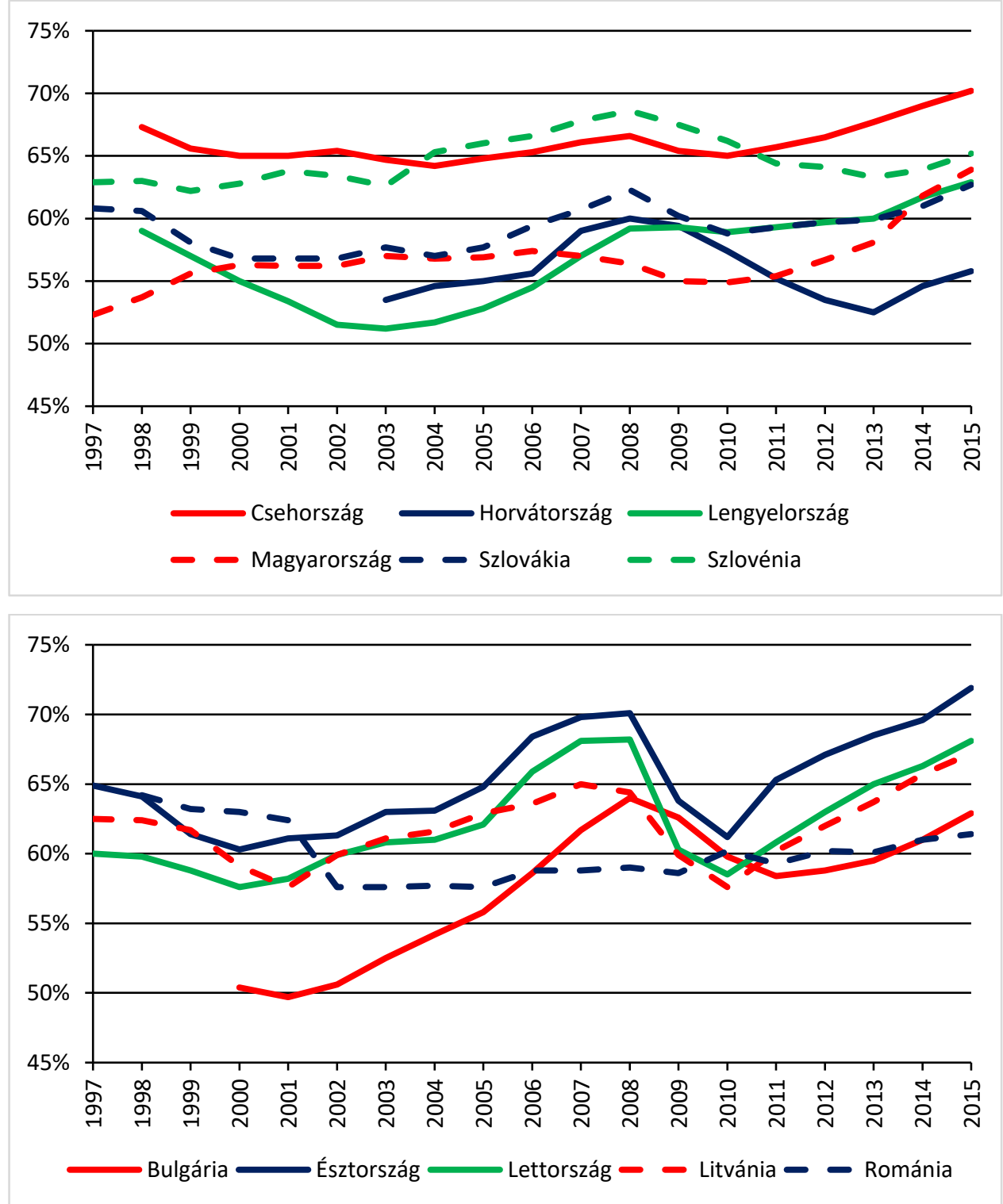

Saját szerkesztés az Eurostat (2016) adatai alapján 
F4. ábra: A nettó beruházási ráta alakulása a kelet-közép-európai országokban
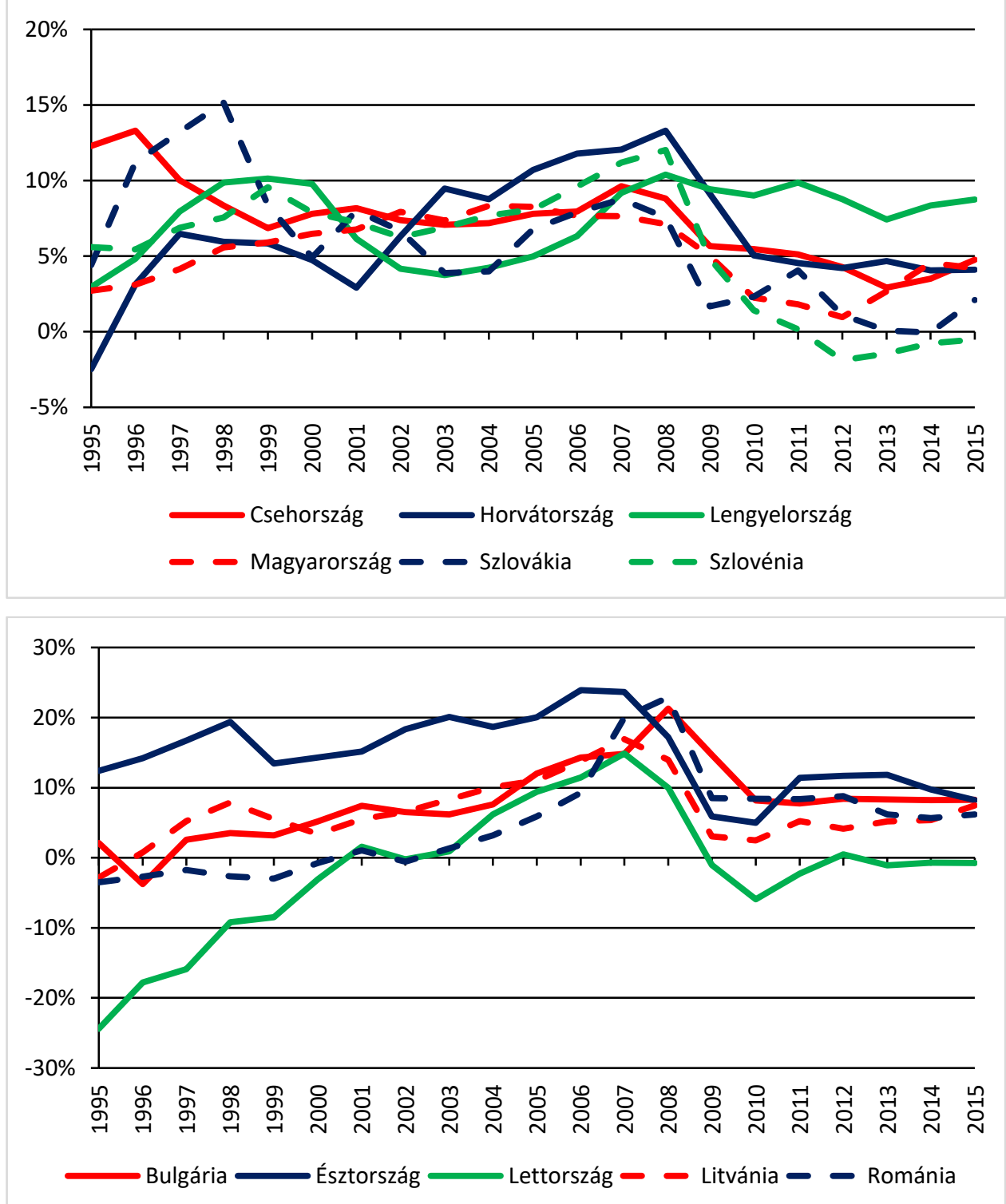

Saját szerkesztés az AMECO (2016) adatai alapján 
F5. ábra: Az éves FDI-beáramlás és a bruttó beruházások arányának alakulása
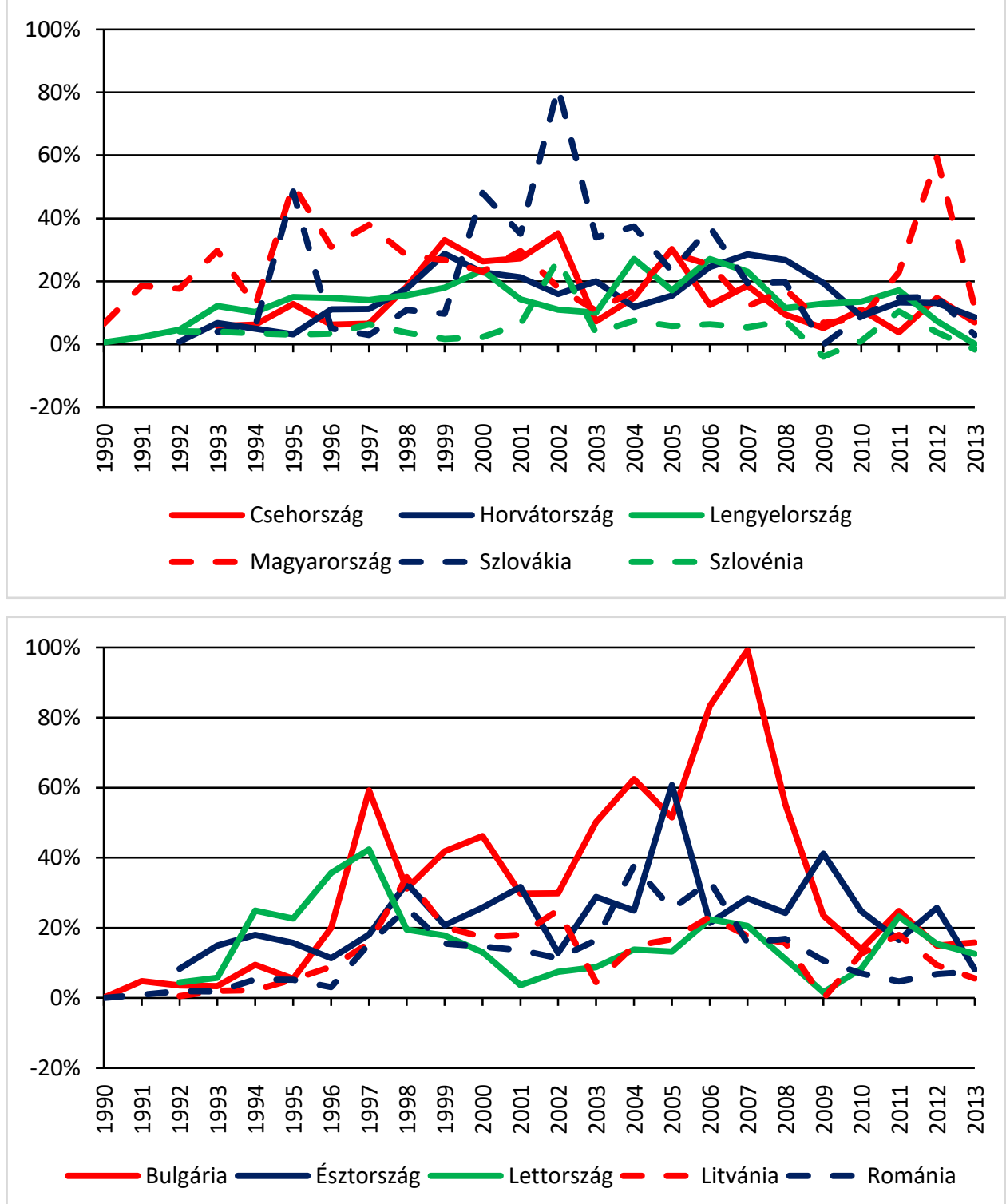

Saját szerkesztés az UNCTAD (2016) adatai alapján 
F6. ábra: A legmagasabb személyi jövedelemadó-kulcsok alakulása a kelet-közép-európai országokban
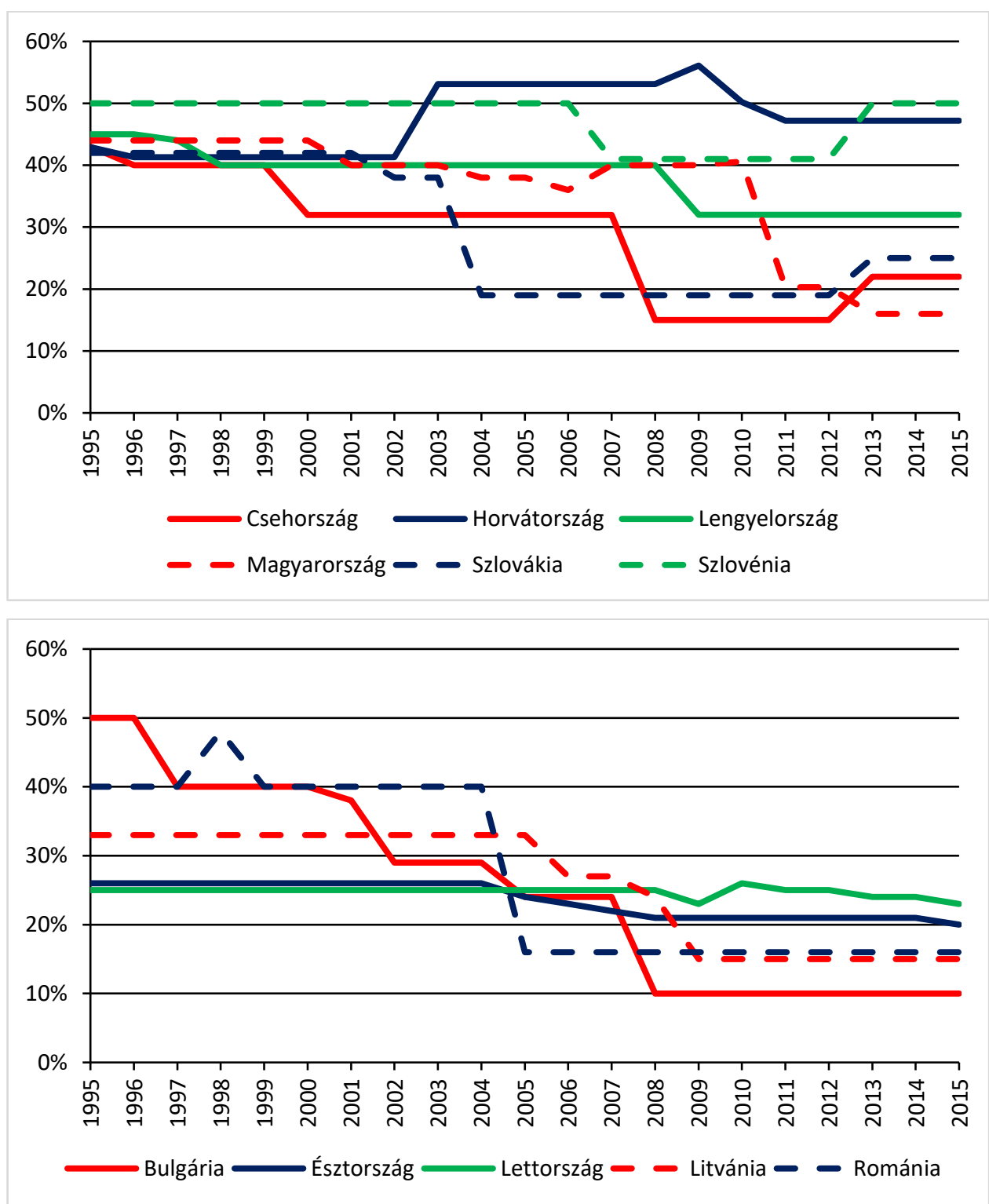

Saját szerkesztés az Eurostat $(2014,2015)$ adatai alapján 
F7. ábra: A vállalati jövedelmeket terhelő legmagasabb adókulcs alakulása a kelet-közép-európai országokban
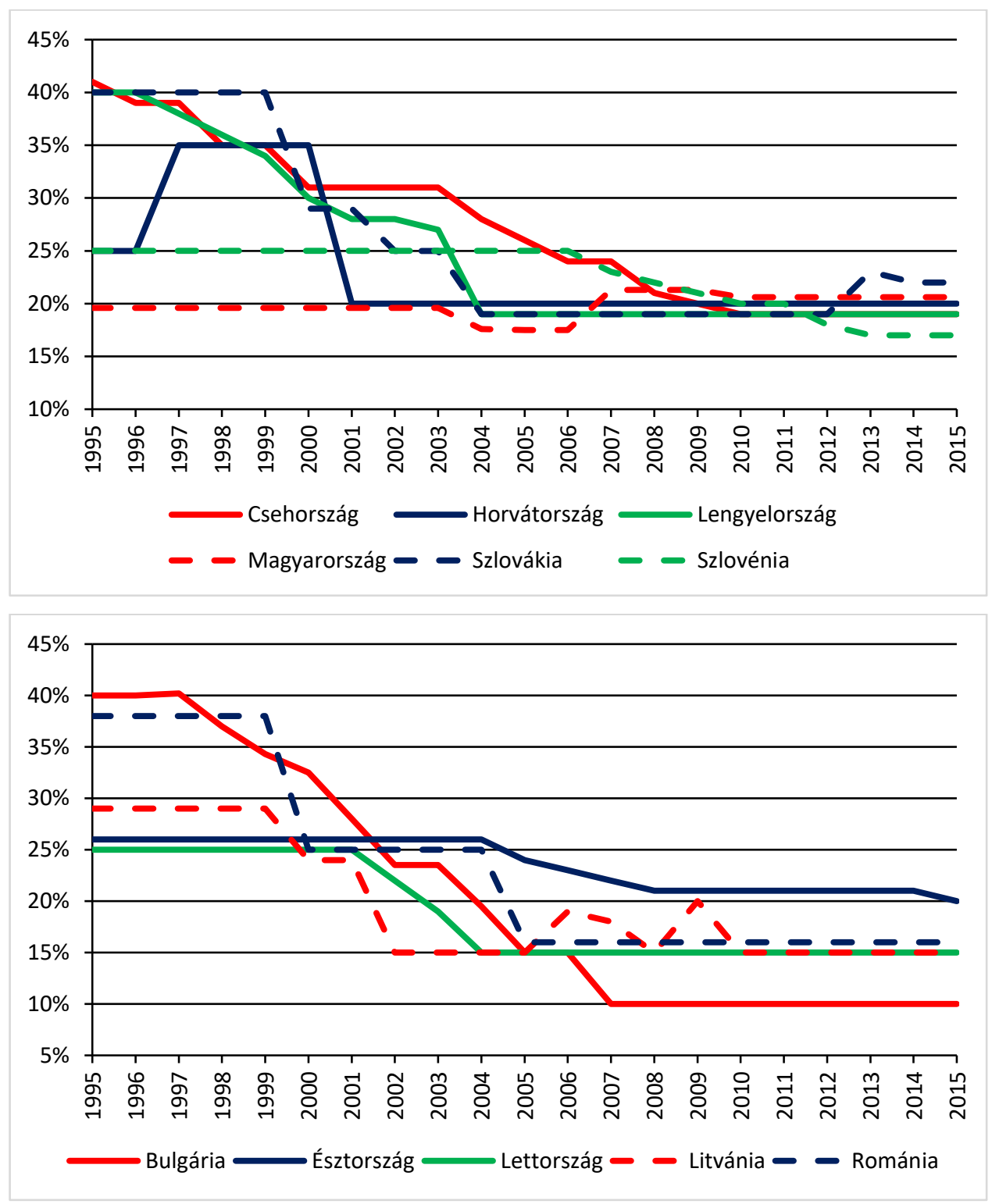

Saját szerkesztés az Eurostat $(2014,2015)$ adatai alapján 
F8. ábra: Az általános áfa-kulcsok alakulása a kelet-közép-európai országokban
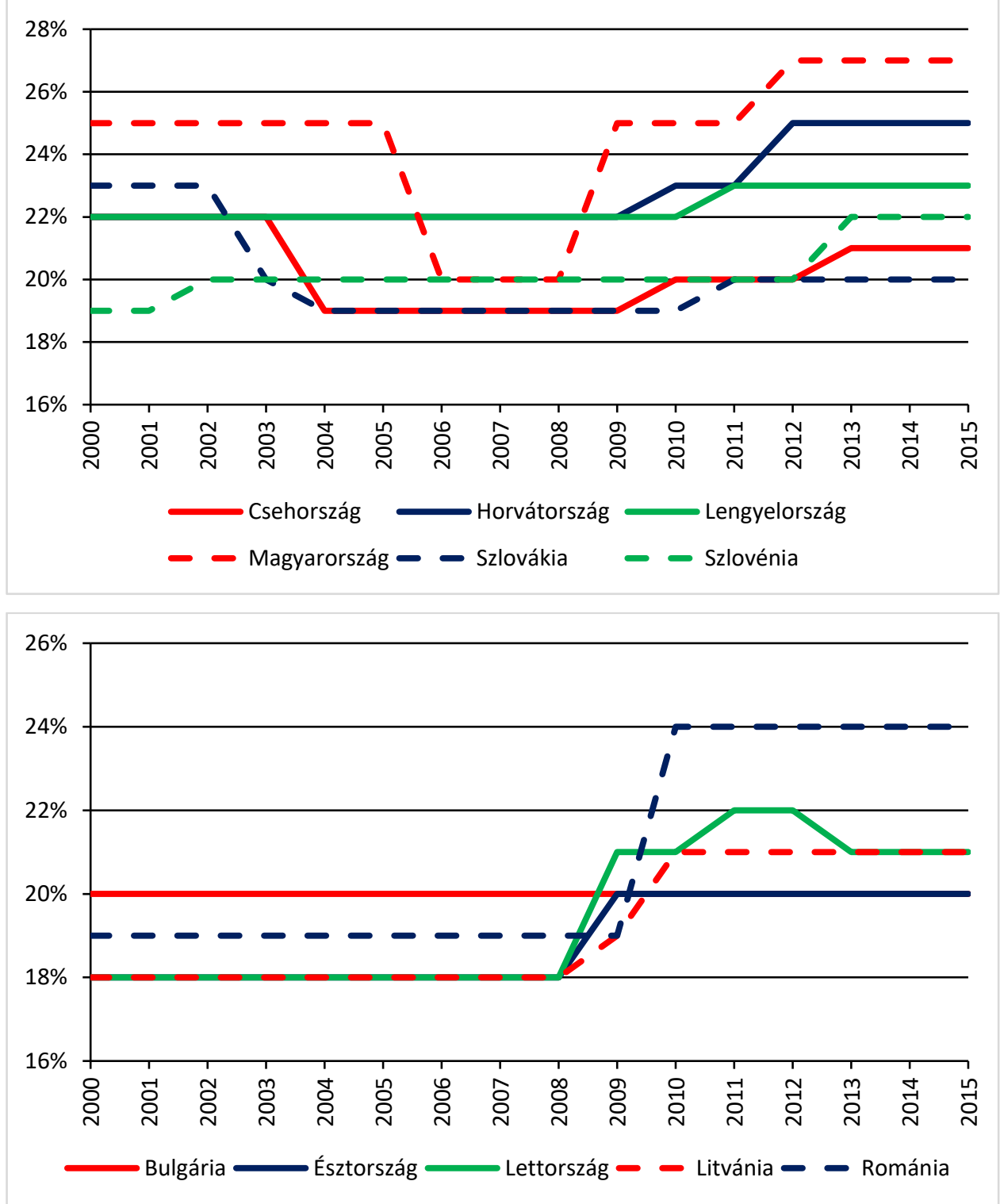

Saját szerkesztés az Eurostat $(2014,2015)$ adatai alapján 


\section{HIVATKOZÁSOK}

Acemoglu, Daron (2009): Introduction to Modern Economic Growth. Princeton Oxford: Princeton University Press

Acemoglu, Daron - Johnson, Simon - Robinson, James A. (2005): „Institutions as the Fundamental Cause of Long-Run Growth." In Aghion, Philippe Durlauf, Steve (szerk.): Handbook of Economic Growth, Volume 1A. Amsterdam: Elsevier, 385-472. oldal,

DOI: http://dx.doi.org/10.1016/S1574-0684(05)01006-3

Aghion, Philippe - Howitt, Peter (1992): „A Model of Growth Through Creative Destruction.” Econometrica, 60. évfolyam, 2. szám, 323-351. oldal,

DOI: http://dx.doi.org/10.2307/2951599

Aghion, Philippe - Howitt, Peter (2009): The Economics of Growth. Cambridge London: MIT Press

Aghion, Philippe - Caroli, Eve - García-Penalosa, Cecilia (1999): „Inequality and Economic Growth: The Perspective of the New Growth Theories." Journal of Economic Literature, 37. évfolyam, 4. szám, 1615-1660. oldal,

DOI: $\underline{\text { http://dx.doi.org/10.1257/jel.37.4.1615 }}$

Alesina, Alberto - Fuchs-Schundeln, Nicola (2005): Good bye Lenin (or not?): The effect of Communism on people's preferences. HIER Discussion Paper 2076, DOI: http://dx.doi.org/10.3386/w11700

Alesina, Alberto - Roubini, Nouriel (1992): „Political Cycles in OECD Economies.” Review of Economic Studies, 59. évfolyam, 4. szám, 663-688. oldal, DOI: http://dx.doi.org/10.2307/2297992

Andrikopoulos, Andreas - Loizides, Ioannis - Prodromidis, Kyprianos (2004): „Fiscal Policy and Political Business Cycles in the EU.” European Journal of Political Economy, 20. évfolyam, 1. szám, 125-152. oldal,

DOI: http://dx.doi.org/10.1016/j.ejpoleco.2003.02.001

Antal László (2004): Fenntartható-e a fenntartható növekedés? Budapest: Közgazdasági Szemle Alapítvány

Aron, Janine (2000): „Growth and Institutions: A Review of the Evidence.” World Bank Research Observer, 15. évfolyam, 1. szám, 99-135. oldal, DOI: http://dx.doi.org/10.1093/wbro/15.1.99 
Arrow, Kenneth J. (1962): „The Economic Implications of Learning by Doing.” Review of Economic Studies, 29. évfolyam, 3. szám, 155-173. oldal, DOI: http://dx.doi.org/10.2307/2295952

Barro, Robert J. (1991): „Economic Growth in a Cross Section of Countries.” Quarterly Journal of Economics, 106. évfolyam, 2. szám, 407-443. oldal, DOI: http://dx.doi.org/10.2307/2937943

Barro, Robert J. - McCleary, Rachel M. (2003): Religion and Economic Growth. NBER Working Paper 9682, DOI: http://dx.doi.org/10.3386/w9682

Becker, Gary S. (1964): Human Capital - A Theoretical and Empirical Analysis, With Special Reference to Education. New York - London: Columbia University Press

Ben-David, Dan (1997): Convergence Clubs and Diverging Economies. Elérhető: http://www4.fe.uc.pt/ mapsd/bdavid_clubs_1997.pdf, letöltve: 2015. augusztus 3 .

Benczes, István (2009): „Fiscal performance and economic growth in the old and new member states of the EU." In Lacina, Lubor - Fidrmuc, Jarko - Rusek, Antonin (szerk.): The economic performance of the European Union. Basingstoke: Palgrave Macmillan, 179-200. oldal

Benczes, István (szerk.) (2014): Deficit and Debt in Transition - The Political Economy of Public Finances in Central and Eastern Europe. Budapest - New York: CEU Press

Benczes, István (2016): „From goulash communism to goulash populism: the unwanted legacy of Hungarian reform socialism." Post-Communist Economies, 28. évfolyam, 2. szám, 146-166. oldal,

DOI: http://dx.doi.org/10.1080/14631377.2015.1124557

Benczes István - Ürögdi András (2008): „A politikai üzleti ciklusok új elmélete és empíriája." Pénzügyi Szemle, 53. évfolyam, 2. szám, 269-282. oldal

Berg, Andrew - Krueger, Anne (2003): Trade, Growth, and Poverty: A Selective Survey. IMF Working Paper WP/03/30

Block, Steven A. (2002): „Political Business Cycles, Democratization and Economic Reform: The Case of Africa." Journal of Development Economics, 67. évfolyam, 1. szám, 205-228. oldal,

DOI: http://dx.doi.org/10.1016/S0304-3878(01)00184-5 
Bod Péter Ákos (2011a): Elpolitizált gazdaság - Magyarország 2002 és 2010 között. Budapest: Magyar Szemle Könyvek

Bod Péter Ákos (2011b): Gazdaságpolitikai döntések válságos időkben - A magyar eset (2008-2010). Budapest: Századvég

Bod Péter Ákos (2014): Nem szokványos gazdaságpolitikák. Budapest: Akadémiai Kiadó

Brender, Adi - Drazen, Allan (2003): Where Does the Political Budget Cycle Really Come From? CEPR Discussion Paper No. 4049

Brender, Adi - Drazen, Allan (2005): „Political Budget Cycles in New Versus Established Democracies.” Journal of Monetary Economics, 52. évfolyam, 7. szám, 1271-1295. oldal

Campos, Nauro F. - Coricelli, Fabrizio (2013): „Economic growth in the transition from communism.” In Hare - Turley (2013), 421-430. oldal

Cass, David (1965): „Optimum Growth in an Aggregative Model of Capital Accumulation." Review of Economic Studies, 32. évfolyam, 3. szám, 233240. oldal, DOI: http://dx.doi.org/10.2307/2295827

Cass, David (1966): „Optimum Growth in an Aggregative Model of Capital Accumulation: A Turnpike Theorem.” Econometrica, 34. évfolyam, 4. szám, 833-850. oldal

Cerra, Valerie - Saxena, Sweta Chaman (2008): „Growth Dynamics: The Myth of Economic Recovery.” American Economic Review, 98. évfolyam, 1. szám, 439-457. oldal, DOI: http://dx.doi.org/10.1257/aer.98.1.439

Clark, Gregory (2007): A Farewell to Alms - A Brief Economic History of the World. Princeton - Oxford: Princeton University Press

Csaba László (2007): „Átmenet vagy spontán rend(etlenség)?” Közgazdasági Szemle, 54. évfolyam, 9. szám, 757-773. oldal

de Menil, Georges (2003): „History, Policy, and Performance in Two Transition Economies: Poland and Romania." In Rodrik, Dani (szerk.): In Search of Prosperity - Analytical Narratives on Economic Growth. Princeton - Oxford: Princeton University Press, 271-294. oldal

Diamond, Peter A. (1965): „National Debt in a Neoclassical Growth Model.” American Economic Review, 55. évfolyam, 5/1. szám, 1126-1150. oldal

Domar, Evsey D. (1946): „Capital Expansion, Rate of Growth, and Employment.” Econometrica, 14. évfolyam, 2. szám, 137-147. oldal 
Domar, Evsey D. (1952): „Economic Growth: An Econometric Approach.” American Economic Review, 42. évfolyam, 2. szám, 479-495. oldal

Dombi Ákos (2013): „Gazdasági növekedés és fejlettség Közép-Kelet-Európában a transzformáció után.” Pénzügyi Szemle, 58. évfolyam, 4. szám, 464-480. oldal

Drazen, Allan (2000): „The Political Business Cycle After 25 Years.” In Bernanke, Ben - Rogoff, Kenneth (szerk.): NBER Macroeconomics Annual 2000. Cambridge: MIT Press, 75-117. oldal, DOI: http://dx.doi.org/10.1086/654407 Easterly, William - Rebelo, Sergio (1993): Fiscal Policy and Economic Growth: An Empirical Investigation. NBER Working Paper 4499,

DOI: http://dx.doi.org/10.3386/w4499

Engen, Eric M. - Skinner, Jonathan (1992): Fiscal Policy and Economic Growth. NBER Working Paper 4223, DOI: http://dx.doi.org/10.3386/w4223

Epaulard, Anne - Pommeret, Aude (2005): Financial Integration, Growth, and Volatility. IMF Working Paper WP/05/67,

DOI: http://dx.doi.org/10.1111/1468-0106.12177

Erős Adrienn (2008): „Az adóstruktúra hatása a gazdasági növekedés hosszú távú ütemére - Elmélet és empíria a magyar adatok tükrében." Pénzügyi Szemle, 53. évfolyam, 3. szám, 451-464. oldal

Eurostat (2014): Taxation trends in the European Union - Data for the EU member states, Iceland and Norway, 2014 edition. Luxembourg: Publications Office of the European Union, DOI: http://dx.doi.org/10.2778/33696

Eurostat (2015): Taxation trends in the European Union - Data for the EU member states, Iceland and Norway, 2015 edition. Luxembourg: Publications Office of the European Union, DOI: http://dx.doi.org/10.2785/298426

Fischer, Stanley (1993): The Role of Macroeconomic Factors in Growth. NBER Working Paper 4565, DOI: http://dx.doi.org/10.3386/w4565

George, Henry (1914 [1879]): Haladás és szegénység. Budapest: Athenaeum Gilbert, Geoffrey (1993): „Introduction.” In Malthus (1993 [1798]), vii-xxv. oldal

Golden, David G. - Poterba, James M. (1980): „The Price of Popularity: The Political Business Cycle Reexamined.” Americal Journal of Political Science, 24. évfolyam, 4. szám, 696-714. oldal, DOI: http://dx.doi.org/10.2307/2110954 
Győrffy Dóra (2008): „Költségvetési kiigazítás és növekedés az Európai Unióban Tanulságok Magyarország számára.” Közgazdasági Szemle, 55. évfolyam, 11. szám, 962-986. oldal

Győrffy, Dóra (2014): „Structural Reforms in a Low-Trust Environment: The Case of Slovakia.” In Benczes (2014), 175-195. oldal

Halász Ágnes (2014): „Politikai költségvetési ciklusok a magyar államháztartásban.” Köz-Gazdaság, 9. évfolyam, 2. szám, 177-194. oldal

Hall, Robert E. - Jones, Charles I. (1999): „Why Do Some Countries Produce So Much More Output Per Worker Than Others?" Quarterly Journal of Economics, 114. évfolyam, 1. szám, 83-116. oldal,

DOI: http://dx.doi.org/10.1162/003355399555954

Halmai, Péter - Vásáry, Viktória (2011): „Crisis and Economic Growth in the EU Medium and Long-term Trends." Acta Oeconomica, 61. évfolyam, 4. szám, 465-485. oldal, DOI: http://dx.doi.org/10.1556/AOecon.61.2011.4.4

Hare, Paul - Turley, Gerald (szerk.) (2013): Handbook of the Economics and Political Economy of Transition. London - New York: Routledge

Harrod, Roy F. (1939): „An Essay in Dynamic Theory.” Economic Journal, 49. évfolyam, 193. szám, 14-33. oldal

Hibbs, Douglas A. (1977): „The Political Parties and Macroeconomic Policy.” American Political Science Review, 71. évfolyam, 4. szám, 1467-1487. oldal, DOI: http://dx.doi.org/10.1017/S0003055406232568

Hild Márta (2002): „Thomas Robert Malthus.” In Bekker Zsuzsa (szerk.): Gazdaságelméleti olvasmányok - Alapmüvek, alapirányzatok. Budapest: Aula, 184186. oldal

Hsieh, Chang-Tai (2002): „What Explains the Industrial Revolution in East Asia? Evidence from the Factor Markets." American Economic Review, 92. évfolyam, 3. szám, 502-526. oldal,

DOI: http://dx.doi.org/10.1257/00028280260136372

Jánossy Ferenc (1966): A gazdasági fejlödés trendvonala és a helyreállítási periódusok. Budapest: Közgazdasági és Jogi Könyvkiadó

Kaldor, Nicholas (1957): „A Model of Economic Growth.” Economic Journal, 67. évfolyam, 268. szám, 591-624. oldal 
Kónya István (2015): „Több gép vagy nagyobb hatékonyság? - Növekedés, tőkeállomány és termelékenység Magyarországon 1995-2013 között.” Közgazdasági Szemle, 62. évfolyam, 11. szám, 1117-1139. oldal,

DOI: http://dx.doi.org/10.18414/KSZ.2015.11.1117

Koopmans, Tjalling C. (1965): „On the Concept of Optimal Economic Growth.” In Study Week on the Econometric Approach to Development Planning, October 7-13, 1963, Citta del Vaticano: Pontificia Academia Scientiarum, 225-300. oldal

Koopmans, Tjalling C. (1967): „Objectives, Constraints, and Outcomes in Optimal Growth Models.” Econometrica, 35. évfolyam, 1. szám, 1-15. oldal, DOI: http://dx.doi.org/10.2307/1909381

Kopits György (2007): „A költségvetési felelősség keretrendszere - Nemzetközi tapasztalatok és magyarországi tanulságok.” Pénzügyi Szemle, 52. évfolyam, 2. szám, 197-216. oldal

Kornai János (1972): Erőltetett vagy harmonikus növekedés - Gondolatok a gazdasági növekedés elméletéröl és politikájáról. Budapest: Akadémiai Kiadó

Kornai János (1980): A hiány. Budapest: Közgazdasági és Jogi Könyvkiadó

Kornai János (1989): Indulatos röpirat a gazdasági átmenet ügyében. Budapest: HVG Kiadó

Kornai János (1993): „Transzformációs visszaesés. Egy általános jelenség vizsgálata a magyar fejlődés példáján.” Közgazdasági Szemle, 40. évfolyam, 7-8. szám, 569-599. oldal

Kornai János (2011): Gondolatok a kapitalizmusról. Budapest: Akadémiai Kiadó

Kozenkow, Judit (2014): „Values, Norms, and Beliefs: The Case of Poland.” In Benczes (2014), 133-152. oldal

Kremer, Michael (1993): „Population Growth and Technological Change: One Million B.C. to 1990." Quarterly Journal of Economics, 108. évfolyam, 3. szám, 681-716. oldal, DOI: http://dx.doi.org/10.2307/2118405

Kutasi, Gábor (2014): „Passive Macroeconomic Populism in the Baltics.” In Benczes (2014), 107-132. oldal

Leontief, Wassily (1986): „Input-Output Analysis.” In Input-Output Economics, $2^{\text {nd }}$ edition. New York - Oxford: Oxford University Press, 19-40. oldal 
Levine, Ross (2005): „Finance and Growth: Theory and Evidence.” In Aghion, Philippe - Durlauf, Steve (szerk.): Handbook of Economic Growth, Volume 1A. Amsterdam: Elsevier, 865-934. oldal,

DOI: http://dx.doi.org/10.1016/S1574-0684(05)01012-9

Lucas, Robert E. (1988): „On the Mechanics of Economic Development.” Journal of Monetary Economy, 22. évfolyam, 1. szám, 3-42. oldal,

DOI: http://dx.doi.org/10.1016/0304-3932(88)90168-7

Maddison, Angus (2001): The World Economy - A Millennial Perspective. Paris: OECD, DOI: http://dx.doi.org/10.1787/9789264022621-en

Malecek, Petr (2015): „The Causes of Post-2009 Differences in the Economic Performance of EU Countries.” Acta Oeconomica, 65. évfolyam, 4. szám, 525545. oldal, DOI: http://dx.doi.org/10.1556/032.65.2015.4.2

Malthus, Thomas (1993 [1798]): An Essay on the Principle of Population. Oxford New York: Oxford University Press

Mankiw, N. Gregory (1999): Makroökonómia. Budapest: Osiris

Mankiw, N. Gregory - Romer, David - Weil, David N. (1992): „A Contribution to the Empirics of Economic Growth." Quarterly Journal of Economics, 107. évfolyam, 2. szám, 407-437. oldal, DOI: http://dx.doi.org/10.2307/2118477

Marer, Paul (2013): „Towards a new growth model in Eastern Europe.” In Hare Turley (2013), 242-260. oldal

Meyer Dietmar - Solt Katalin (1999): Makroökonómia. Budapest: Aula

Mincer, Jacob (1958): „Investment in Human Capital and Personal Income Distribution.” Journal of Political Economy, 66. évfolyam, 4. szám, 281-302. oldal, DOI: http://dx.doi.org/10.1086/258055

Mink, Mark - de Haan, Jakob (2006): „Are There Political Budget Cycles in the Euro Area?" European Union Politics, 7. évfolyam, 2. szám, 191-211. oldal, DOI: http://dx.doi.org/10.1177/1465116506063706

Móczár József (2008): Fejezetek a modern közgazdaság-tudományból. Budapest: Akadémiai Kiadó

Neumann, John von (1945-1946): „A Model of General Economic Equilibrium.” Review of Economic Studies, 13. évfolyam, 1. szám, 1-9. oldal, DOI: $\underline{\text { http://dx.doi.org/10.2307/2296111 }}$

Nordhaus, William D. (1975): „The Political Business Cycle.” Review of Economic Studies, 42. évfolyam, 2. szám, 169-190. oldal 
Oblath Gábor (2014a): „Gazdasági instabilitás és regionális lemaradás - Magyarország esete.” Külgazdaság, 58. évfolyam, 5-6. szám, 1-38. oldal

Oblath Gábor (2014b): „Gazdasági átalakulás, nekilendülés és elakadás - Magyarország makrogazdasági konvergenciája az Európai Unió fejlett térségéhez az 1990-es évek elejétöl 2013-ig.” In Kolosi Tamás - Tóth István György (szerk.): Társadalmi Riport 2014. Budapest: Tárki, 21-50. oldal

OECD (2003): The Sources of Economic Growth in the OECD Countries. Paris: OECD, DOI: http://dx.doi.org/10.1787/9789264199460-en

Phelps, Edmund (1961): „The Golden Rule of Accumulation: A Fable for Growthmen.” American Economic Review, 51. évfolyam, 4. szám, 638-643. oldal, DOI: http://dx.doi.org/10.1016/B978-0-12-554002-5.50007-8

Quah, Danny T. (1996): „Twin Peaks: Growth and Convergence in Model of Distribution Dynamics.” Economic Journal, 106. évfolyam, 437. szám, 10451055. oldal, DOI: http://dx.doi.org/10.2307/2235377

Ramsey, Frank P. (1928): „A Mathematical Theory of Saving.” Economic Journal, 38. évfolyam, 152. szám, 543-559. oldal, DOI: http://dx.doi.org/10.1111/ecoj.12229

Reinhart, Carmen M. - Rogoff, Kenneth S. (2010): „Growth in a Time of Debt.” American Economic Review, 100. évfolyam, 2. szám (Papers and Proceedings of the One Hundred Twenty Second Annual Meeting of the American Economic Association), 573-578. oldal,

DOI: http://dx.doi.org/10.1257/aer.100.2.573

Rivera-Batiz, Luis A. - Romer, Paul M. (1991): „Economic Integration and Endogenous Growth." Quarterly Journal of Economics, 106. évfolyam, 2. szám, 531-555. oldal, DOI: http://dx.doi.org/10.2307/2937946

Rogoff, Kenneth (1990): „Equilibrium Political Budget Cycles.” American Economic Review, 80. évfolyam, 1. szám, 21-36. oldal

Rogoff, Kenneth - Sibert, Anne (1988): „Elections and Macroeconomic Policy Cycles." Review of Economic Studies, 55. évfolyam, 1. szám, 1-16. oldal, DOI: $\underline{\text { http://dx.doi.org/10.2307/2297526 }}$

Romer, David (2001): Advanced Macroeconomics, $2^{\text {nd }}$ edition. Boston etc.: McGraw-Hill 
Romer, Paul M. (1986): „Increasing Returns and Long-Run Growth.” Journal of Political Economy, 94. évfolyam, 5. szám, 1002-1037. oldal, DOI: http://dx.doi.org/10.1086/261420

Romer, Paul M. (1990): „Endogenous Technological Change.” Journal of Political Economy, 98. évfolyam, 5/2. szám, S71-S102. oldal

Sato, Ryuzo (1964): „The Harrod-Domar Model vs the Neo-Classical Growth Model.” Economic Journal, 74. évfolyam, 294. szám, 380-387. oldal

Schuknecht, Ludger (2000): „Fiscal Policy Cycles and Public Expenditure in Developing Countries.” Public Choice, 102. évfolyam, 1-2. szám, 113-128. oldal, DOI: http://dx.doi.org/10.1023/A:1005026806998

Schultz, Theodore W. (1963): The Economic Value of Education. New York - London: Columbia University Press

Schultz, Theodore W. (1971): Investment in Human Capital. New York: The Free Press

Schumpeter, Joseph A. (1980 [1934]): A gazdasági fejlödés elmélete. Budapest: Közgazdasági és Jogi Könyvkiadó

Schumpeter, Joseph A. (1987 [1943]): Capitalism, Socialism and Democracy. London: Unwin Paperbacks

Smith, Adam (1999 [1776]): An Inquiry into the Nature and Causes of the Wealth of Nations. London: Penguin Books

Solow, Robert M. (1956): „A Contribution to the Theory of Economic Growth.” Quarterly Journal of Economics, 70. évfolyam, 1. szám, 65-94. oldal, DOI: http://dx.doi.org/10.2307/1884513

Solow, Robert M. (1957): „Technical Change and the Aggregate Production Function." Review of Economics and Statistics, 39. évfolyam, 3. szám, 312320. oldal

Solow, Robert M. (2015): „The Future of Work: Why Wages Aren't Keeping Up.” Pacific Standard, August 11

Solow, Robert M. - Samuelson, Paul A. (1953): „Balanced Growth under Constant Returns to Scale.” Econometrica, 21. évfolyam, 3. szám, 412-424. oldal, DOI: $\underline{\text { http://dx.doi.org/10.2307/1905447 }}$

Sørensen, Peter Birch - Whitta-Jacobsen, Hans Jørgen (2005): Introducing Advanced Macroeconomics: Growth \& Business Cycles. London etc.: McGraw-Hill 
Sutela, Pekka (2013): „Estonia - Did the strategy of deep integration fail in the 2008/09 crisis?” In Hare - Turley (2013), 376-383. oldal

Takács, Vera - Benczes, István (2014): „The Strategic Use of Public Debt in Central and Eastern Europe.” In Benczes (2014), 59-86. oldal

Thirlwall, Anthony P. (2011): „Balance of Payments Constrained Growth Models: History and Overview." PSL Quarterly Review, 64. évfolyam, 259. szám, 307-351. oldal

Turley, Gerald (2013): „Transition economies - The first two decades.” In Hare Turley (2013), 17-33. oldal

Williamson, Stephen D. (2009): Makroökonómia. Budapest: Osiris

Young, Alwyn (1995): „The Tyranny of Numbers: Confronting the Statistical Realities of the East Asian Growth Experience." Quarterly Journal of Economics, 110. évfolyam, 3. szám, 641-680. oldal,

DOI: http://dx.doi.org/10.2307/2946695

Uzawa, Hirofumi (1965): „Optimum Technical Change in an Aggregative Model of Economic Growth." International Economic Review, 6. évfolyam, 1. szám, 18-31. oldal

Zalai Ernő (2000): Matematikai közgazdaságtan. Budapest: KJK-Kerszöv 


\section{FELHASZNÁLT ADATBÁZISOK}

AMECO (2016): Annual Macroeconomic Database. European Commission,

Directorate General for Economic and Financial Affairs, elérhető:

http://ec.europa.eu/economy_finance/ameco/user/serie/SelectSerie.cfm

CIA (2016): The World Factbook. Central Intelligence Agency, elérhető:

https://www.cia.gov/library/publications/resources/the-world-factbook/

EBRD (2016): Forecasts, macro data, transition indicators. European Bank for

Reconstruction and Development, elérhetö:

http://www.ebrd.com/what-we-do/economic-research-and-

data/data/forecasts-macro-data-transition-indicators.html

EC (2015): EU expenditure and revenue 2000-2015 data. European Commission, elérhetö:

http://ec.europa.eu//budget/financialreport/2015/keyachievements/index_en.html

Eurostat (2016): Eurostat Database. European Commission, elérhető:

http://ec.europa.eu/eurostat/data/database

Maddison Project (2013): Maddison Project Database, 2013 version. elérhető:

http://www.ggdc.net/maddison/maddison-project/home.htm

UNCTAD (2016): UNCTADStat Data Center. United Nations Conference on Trade and Development, elérhetö:

http://unctadstat.unctad.org/wds/ReportFolders/reportFolders.aspx?sCS_Chos enLang=en

UNSTATS (2016): National Accounts Main Aggregates Database. United Nations Statistics Division, elérhető:

http://unstats.un.org/unsd/snaama/Introduction.asp 


\section{A JELÖLTNEK A TÉMÁBAN SZÜLETETT PUBLIKÁCIÓI}

Németh András Olivér (2009): Fiskális fegyelmezetlenség és gazdasági növekedés. A BCE Közgazdasági Doktori Iskola V. éves konferenciája, 2009. október 30.

Németh András Olivér (2010): Makrogazdaság-politika és növekedés Kelet-KözépEurópában. A BCE Közgazdasági Doktori Iskola VI. éves konferenciája, 2010. október 29.

Németh András Olivér (2011a): „A politika, a gazdaságpolitika és a gazdasági folyamatok.” In Bod Péter Ákos: Gazdaságpolitikai döntések válságos időkben - A magyar eset (2008-2010). Budapest: Századvég, 95-134. oldal

Németh András Olivér (2011b): „Makrogazdaság-politika és növekedés.” In Gondolatok közös javainkról: Válság az oktatásban? Oktatás a válságban! - A Közgazdaságtudományi Kar 2010. évi konferenciája. Budapest: BCE Közgazdaságtudományi Kar, 98-115. oldal

Németh András Olivér (2011c): Növekedési regressziók - egy empirikus kutatás jelenlegi eredményei. A BCE Közgazdasági Doktori Iskola VII. éves konferenciája, 2011. október 28.

Németh András Olivér (2012a): A kelet-közép-európai országok adóztatási gyakorlatának bemutatása. A BCE Közgazdasági Doktori Iskola VIII. éves konferenciája, 2012. november 5.

Németh András Olivér (2012b): „Makrogazdaság-politika és gazdasági növekedés elmélet és empíria.” In Tavaszi Szél 2012 Konferenciakötet. Budapest: Doktoranduszok Országos Szövetsége, 561-567. oldal.

Németh András Olivér (2013): A gazdasági növekedés tényezői Kelet-KözépEurópában. A BCE Közgazdasági Doktori Iskola IX. éves konferenciája, 2013. november 22.

Németh, András Olivér (2014): „Political Business Cycles: Theory and Empirical Findings for the CEE Region.” In Benczes, István (szerk.): Deficit and Debt in Transition - The Political Economy of Public Finances in Central and Eastern Europe. Budapest - New York: CEU Press, 35-57. oldal

Németh András Olivér (2015a): A kelet-közép-európai országok növekedésének empirikus vizsgálata. A BCE Általános és Kvantitatív Közgazdaságtan Doktori Iskola XI. éves konferenciája, 2015. november 12. 
Németh András Olivér (2015b): „Politikai költségvetési ciklusok Kelet-KözépEurópában - Elmélet és empíria.” Köz-Gazdaság, X. évfolyam, 4. szám, 167178. oldal

Németh András Olivér (2017a): „A növekedéselmélet fejlődéstörténete I. - A kezdetektől a Solow-modellig.” Köz-Gazdaság, közlésre elfogadva, várható megjelenés: XII. évfolyam, 1. szám

Németh András Olivér (2017b): „A növekedéselmélet fejlődéstörténete II. - A neoklasszikus modellektől a növekedés fundamentális okaiig.” Köz-Gazdaság, közlésre elfogadva, várható megjelenés: XII. évfolyam, 2. szám 